\title{
Politics of Quality in Education
}

The question of quality has become one of the most important framing factors in education and has been of growing interest to international organisations and national policymakers for decades. Politics of Quality in Education focuses on Brazil, China, and Russia, part of the so-called emerging nations' BRICS block, and draws on a four-year project to develop a new theoretical and methodological approach.

The book builds a comparative, sociohistorical, and transnational understanding of political relations in education, with a particular focus on the policies and practices of quality assurance and evaluation (QAE). Tracking QAE processes from international organisations to individual schools, contributors analyse how QAE changes the dynamics in the roles of state, expertise, and governance. The book demonstrates how national and sub-national actors play a central role in the adaptation, modification, or rejection of transnational policies.

Politics of Quality in Education will be of great interest to academics, researchers, and postgraduate students engaged in the study of comparative and international education, as well as educational policy and politics. It should also be essential reading for practitioners and policymakers.

Jaakko Kauko is Associate Professor of Education at the Faculty of Education, University of Tampere. His research focuses on the fields of education policy and comparative education.

Risto Rinne is Professor of Education, Vice-Dean and Head of the Department of Education and the Centre for Research on Lifelong Learning and Education (CELE) at the University of Turku, Finland. He is a member of the Finnish Academy of Science and Letters and has published more than 500 scientific works.

Tuomas Takala is Professor Emeritus of Comparative Education at the Faculty of Education, University of Tampere. His research has focused on the formation and implementation of education policies in developing countries. 


\section{Routledge Research in International and Comparative Education}

This is a series that offers a global platform to engage scholars in continuous academic debate on key challenges and the latest thinking on issues in the fastgrowing field of international and comparative education.

Titles in the series include:

Educational Choices, Aspirations and Transitions in Europe

Systemic, Institutional and Subjective Constraints

Edited by Aina Tarabini and Nicola Ingram

Cooperative Education in Asia

History, Present and Future Issues

Edited by Yasushi Tanaka

\section{Testing and Inclusive Schooling}

International Challenges and Opportunities

Edited by Bjorn Hamre, Anne Morin, and Christian Ydesen

\section{Vocational Education in the Nordic Countries}

The Historical Evolution

Edited by Svein Michelsen and Marja-Leena Stenström

\section{Vocational Education in the Nordic Countries}

Learning from Diversity

Edited by Christian Helms Jorgensen, Ole Johnny Olsen, and Daniel Persson

Thunquist

\section{Higher Education and China's Global Rise}

A Neo-Tributary Perspective

Su-Yan Pan and Joe Tin-Yau Lo

For more information about this series, please visit: www.routledge.com/Rout ledge-Research-in-International-and-Comparative-Education/book-series/ RRICE 


\section{Politics of Quality in Education}

A Comparative Study of Brazil, China, and Russia

Edited by Jaakko Kauko, Risto Rinne, and Tuomas Takala 
First published 2018

by Routledge

2 Park Square, Milton Park, Abingdon, Oxon OX14 4RN

and by Routledge

711 Third Avenue, New York, NY 10017

Routledge is an imprint of the Taylor \& Francis Group, an informa business

(C) 2018 selection and editorial matter, Jaakko Kauko, Risto Rinne, and

Tuomas Takala; individual chapters, the contributors

The right of the editor to be identified as the author of the editorial material, and of the authors for their individual chapters, has been asserted in accordance with sections 77 and 78 of the Copyright, Designs and Patents Act 1988.

The Open Access version of this book, available at www.taylorfrancis.com, has been made available under a Creative Commons Attribution-Non Commercial-No Derivatives 4.0 license.

Trademark notice: Product or corporate names may be trademarks or registered trademarks, and are used only for identification and explanation without intent to infringe.

British Library Cataloguing-in-Publication Data

A catalogue record for this book is available from the British Library

Library of Congress Cataloging-in-Publication Data

A catalog record for this book has been requested

ISBN: 978-1-138-55973-8 (hbk)

ISBN: 978-0-203-71230-6 (ebk)

Typeset in Bembo

by Apex CoVantage, LLC 


\section{Contents}

List of tables and figure vii

Foreword viii

ANTÓNIO NÓVOA

Acknowledgements $\quad \mathrm{xV}$

List of contributors xvi

Biographies xvii

1 Comparing politics of quality in education 1

JAAKKO KAUKO, TUOMAS TAKALA, AND RISTO RINNE

2 Layers of reflectivity in comparative research 18

JAAKKO KAUKO, VERA GORODSKI CENTENO, NELLI PIATTOEVA, HELENA CANDIDO, GALINA GUROVA, ANNA MEDVEDEVA, ÍRIS SANTOS, OLLI SUOMINEN, AND XINGGUO ZHOU

3 Historical paths to shared interest in quality assurance and evaluation

OLLI SUOMINEN, VERA GORODSKI CENTENO, GALINA GUROVA, JOHANNA KALLO, AND XINGGUO ZHOU

4 Established and emerging actors in the national political arenas

JAAKKO KAUKO, OLLI SUOMINEN, VERA GORODSKI CENTENO,

NELLI PIATTOEVA, AND TUOMAS TAKALA

5 Changing expertise and the state

RISTO RINNE, XINGGUO ZHOU, JAAKKO KAUKO, ROMUALD

NORMAND, ANNA MEDVEDEVA, AND ÍRIS SANTOS 
vi Contents

6 Governance by data circulation? The production, availability, and use of national large-scale assessment data

NELLI PIATTOEVA, VERA GORODSKI CENTENO, OLLI SUOMINEN, AND RISTO RINNE

7 Effects of quality assurance and evaluation on schools' room for action

GALINA GUROVA, HELENA CANDIDO, AND XINGGUO ZHOU

8 Alternative views of the future of quality assurance and evaluation

JOHANNA KALLO, TUOMAS TAKALA, VERA GORODSKI CENTENO, AND OLLI SUOMINEN

9 Conclusion

JAAKKO KAUKO, RISTO RINNE, AND TUOMAS TAKALA

Appendix 1: Interview data and codes

Appendix 2: Coding of interviews

Appendix 3: Interview guidelines

Index 


\section{Tables and figure}

\section{Tables}

2.1 CADEP framework for analysing QAE in this book 21

2.2 Main themes and goals in the collection and analysis of data 26

9.1 Dynamics in the politics of quality in Brazil, China, and Russia 182

10.1 Number of interviews and interviewees in the BCR project 192

\section{Figure}

2.1 Dimensions of the analytical framework (CADEP) and the book's chapters 


\section{Foreword}

Theoretically, Politics of Quality in Education is a very solid and consistent book. Its authors bring new elements to an understanding of one of the central themes in the configuration of education policies in recent decades.

Based on a comparative study of three BRICS countries - Brazil, China, and Russia - new perspectives are opened for thinking about and interpreting "how the emphasis on quality has changed the basic conditions in which education takes place" (this book, p. 1).

As David Labaree states, in the twenty-first century, the education policy discourse converges on a single overarching goal for education:

From the global education reform movement to its policy apparatus in the OECD and its policy police in the PISA testing program, we have seen one goal trump the others... The OECD approach serves to narrow the learning outcomes of schooling and educational knowledge production to whatever is in service to economic development.

(2017: pp. 281-282)

The argument of the book is developed against this background. The idea of quality in education, as it is circulated throughout the world, is here operationalised as a governance tool. It is clear from the outset that the central issues "for analysing quality in education globally are how quality is connected to transnational flows of knowledge and how it offers a powerful governance tool" (this book, p. 5).

The authors reveal an excellent knowledge of the state of the art but above all a rare intellectual sophistication. They do not fall into pre-established theoretical frameworks which explain everything even before the research is undertaken or into dichotomies which so often close and diminish the interpretation of educational and political issues.

On the contrary, throughout the book, we are driven to a systematic problematisation, opening new interpretive paths and new perspectives to consider the political themes of quality in education. Written with elegance and sagacity, the book does not seek to avoid complexity. There are no easy answers but rather an invitation for the reader to subscribe to multiple interwoven interpretations. 
The authors explain, "Before it is operationally defined, 'quality in education' remains abstract and elusive ... it is not until it is put into practice, or 'operationalised', that it becomes definable" (this book, p. 1). In this sense, they seek to investigate how the operationalisation of quality takes place and the repercussions this has on the room for action of the different actors involved in education.

They assume the need to take into account, simultaneously, the world's complexity and contingency to understand the political processes in the education arena. Instead of discussing questions about source and target, global and local, convergence and divergence, they are interested in understanding networks, flows, and complex causation.

The research is organised around a triangle whose vertices are the political situation, the political possibilities, and the use of political space. Through this scheme, the authors seek to understand the politics of quality in Brazil, China, and Russia: first, they explain how quality assurance and evaluation strategies have become the goal of education instead of quality itself; then, they describe how these strategies "[enable] a parallel trend of authorising more governance methods, but at the same time [create] increasingly complex systems" (this book, p. 11); finally, they clarify how these strategies bring new actors and reconfigurations of the field and point to their potential for changing policies in education.

In this foreword, I would like to underline two points that are relevant for an understanding of the intellectual effort made in this work.

The first concerns the need to go beyond the traditional divisions of space, either in the opposition between the global and the local or in a strict vision of national boundaries, which typically confine comparative studies to rigid and uninteresting frameworks.

Nowadays, the question does not lie mainly in a logic of transfer, export, and import, but rather in understanding how we all, through our own network presence and collaboration, contribute first to the delocalisation and then to the relocalisation of policies. It is not about a space with rigid locations or without locations but instead about a space with multiple locations.

The second point concerns the attention given in recent years to the dematerialisation of space, with a more complex analysis of flows, communications, networks, and connections. These studies often tend to accentuate fluidity as if it were fluctuation, without paying due attention to key dimensions brought to the scientific debate by authors like Anna Tsing or Tim Cresswell. I am referring to the concepts of friction and turbulence.

Anna Tsing (2005) explains that without friction, movement would be impossible. The surfaces would slide into each other in a frictionless fluidity, which would make any kind of traction - that is, movement - impossible.

Likewise, Tim Cresswell (2010), working on mobilities, invites us not to see turbulence as a moment of breakdown - a fundamentally bad thing - but rather as an event of creative potentiality. Moments of turbulence produce sudden visibilities in systems which would otherwise remain mostly invisible and taken for granted. 
These two perspectives cross the book, edited by Jaakko Kauko, Risto Rinne, and Tuomas Takala, in which the ideas of complexity and contingency are taken as an epistemological starting point.

The major interest of this research is its ability to advance interpretations which escape the traditional frameworks and allow us to understand the importance of the politics of quality in education in three different countries. The interpretative potentialities of a research which crosses several countries, in this case Brazil, China, and Russia, become evident in this book, which brings an important renewal to comparative studies.

Methodologically, this work is very thoughtful and innovative, opening new and important perspectives for comparative studies in education. I would like to draw attention to two dimensions which are very relevant in the way the research was conducted.

The first is the selection of the countries on which the comparison is based. The idea of choosing them from the BRICS universe is particularly interesting, because we find here a political intention to bring together very different countries, with very different histories, but all of them experiencing a historical period of affirmation on the international scene.

This choice allows one of the central research questions to be posed: can we consider that these countries are in a transition phase from "norm-takers" to "norm-makers" in the global environment?

The conclusions refer to three different ways of approaching the relationship with the politics of quality in education: in Brazil, a strong pace towards assessment and a slow pace towards quality are identified; in China, the imperial legacies and the needs of the party-state, leading to the construction of QAE strategies with Chinese characteristics, are mentioned; finally, it is suggested that in Russia, quality control serves to reinforce central regulation.

In general, we can consider that global policies of quality in education prevail over any alternatives tried in the BRICS space. It is true that, under the New Delhi Declaration of Education, signed in 2016, these countries commit themselves to "share the best practices available in BRICS countries in collaboration in education, research and innovation through the BRICS Network University". However, one must recognise the political fragility of these intentions.

It is in this sense that one can interpret the occasionally harsh judgements which heads of international organisations, for example PISA, allow themselves to address to national officials who fail to follow their "recommendations".

In this respect, an interview with Andreas Schleicher, Education Policy Officer of the OECD, with Veja, a leading Brazilian magazine, is revealing:

Brazil has begun to have a chance to move forward from the moment that it began to map problems objectively - and no longer on the basis of the intuition of the rulers. This is basic. We cannot think of improving 
what has not even been measured. Hence the importance of international comparison.

(see Weinberg 2008: pp. 20-21)

The central goal of PISA, well beyond the BRICS, is to contribute to the "modernisation" of education systems in the face of the challenges of the knowledge economy and globalisation.

In other words, it is a matter of defining what each country must "necessarily" embrace and implement. Each state in its "freedom" must "inevitably" adopt these recommendations. Indeed, indicators, and mainly quality indicators, are never a mere description of reality. They provide a way of constructing reality, of defining what is important and what is not, of establishing priorities, which inevitably influence actions and policies. And the situation is no different in the world of BRICS.

The second dimension which seems relevant to me is the choice of comparative research strategies. The authors do not confine themselves to traditional methodologies, whether country-to-country comparisons or macro-analyses as developed by world-system approaches.

They are able to define intermediate levels of comparison which do not ignore the historical specificity of each country or the interest of a more general view but which allow them to build a more sophisticated, strongly comparative, open, and problematising analysis. They call their approach "comparing dynamics", emphasising that they are interested in movement in education politics.

This is what allows them to elucidate not so much cross-national comparisons but the creation and ongoing re-creations of "global signifiers" based on international competition and assessments. This process leads to the diffusion of global patterns and flows of knowledge which are assumed to be applicable in various places. These international indicators and benchmarks are not spontaneously generated. On the contrary, they are the result of policy-oriented educational and social research.

The work of methodological construction carried out in this project, both in the initial phase of conception and in the development of the cross-analysis of the three cases, deserves special mention. We are facing significant advances in comparative work in education, which means that this book will be mandatory reading for researchers wishing to embark on comparative studies in the field of education and politics.

In addition to these two dimensions, it is fair to point out the authors' care in the organisation of their research, as well as in the analysis and interpretation of the data. It is very interesting that they assume, from the outset, that "the key to maintaining validity in a qualitative research project such as ours is to adopt a reflective approach throughout" (this book, p. 18).

Indeed, throughout the book there is an attitude of self-reflexivity, which leads the authors to relativise their advanced interpretations. They explain this permanent exercise through a research which is conscious of the interpretation 
made, prudent with the systematics of the research procedure, aware of the political and ideological role of social science research, and reflective in terms of representation and authority.

This attitude leads them to a permanent swing between the explanation of their interpretations and the cultivation of a doubt, which opens space for other interpretations. We all know that the best science feeds on doubt and does not fall into the arrogance of certainties, which are the shortest route to ignorance.

Intellectually, this is a bright book. The authors produce a very important set of reflections and open important perspectives for future studies, in particular concerning the role of experts and quality policies in education. In this sense, they explain that changes in the political agenda of the countries analysed are related to changes in actor constellations.

The analysis of national and international experts and the role they play is crucial for the argument developed in the book. The way they influence decisions and change the political landscape is particularly relevant in the debate on quality education issues.

In this regard, I would like to return to the criticism made forty years ago by a very influential, but easily forgotten, author, Ivan Illich:

Experts and an expert culture always call for more experts. Experts also have a tendency to cartelize themselves by creating "institutional barricades"-for example proclaiming themselves gatekeepers, as well as self-selecting themselves. Finally, experts control knowledge production, as they decide what valid and legitimate knowledge is, and how its acquisition is sanctioned.

(see Finger \& Asún 2001: p. 10)

As this book explains, education policies are increasingly influenced by an expert-discourse. However, after so many studies confirming this over-presence, it is worth returning to a concept developed by Ivan Illich: counterproductivity.

Counterproductivity is the means by which an intrinsically useful and beneficial process can turn into something negative. Illich's idea applies to different situations and contexts: medicalisation of health, schooling, car traffic, technologies, and so on. He argues that beyond a certain point medicine generates disease, transportation generates congestion, and education causes adverse effects (Illich 1977: p. 28).

I believe this critique remains accurate. It can easily be applied to the production of statistical indicators which, beyond a certain point, proves counterproductive. In this sense, we need to imagine a different, more critical and reflective use of the "numbers" available to us.

Indicators are an important support for our interpretations of the world, but they cannot take the place of our judgements and choices. Comparison is a way of understanding the world critically but not a way of governing it, as if 
policies were a "simple", "neutral", and "objective" administration of the results presented in a list of indicators.

In this sense, comparative work in education should not serve to "expropriate" citizens' decision-making capacity in favour of experts and an expertdiscourse but rather to provide elements and interpretations which allow them to "appropriate" politics.

We have an urgent need to proceed with a methodological revolution of comparative approaches. It is no longer possible to gaze fixedly at the concrete ground of "realities" which do not allow comparative reflection. It is no longer possible to generalise concepts without roots by constructing a vague and floating thought.

Like history, comparative research must not focus on "facts" or "realities" but on problems. The "facts" - events, countries, systems, and so on - are, by definition, incomparable. We can illuminate the "specificities" and "similarities", but we cannot go further. Only problems can be the basis of a comparative reflection, because they situate us in the face of our memories and imaginations, producing new areas of examining a space which is not delimited by physical boundaries but rather by boundaries of meaning.

For a long time, democratisation was at the forefront of education research. We must re-establish this lost tradition, against the myth of the "objective expert". It is necessary to rebuild a culture of discussion and debate, of reading each other's work and engaging in meaningful intellectual conversation. We must reinvent research as an open collective praxis.

Our best tradition relies on multiple approaches and ways of thinking. We need to enrich, to deepen, and to diversify our understanding of education matters, which also happens through comparison. There is no simple way to accomplish this goal. We cannot hope to reach a consensus on how to organise and conduct research in education. But we can engage in an intellectual dialogue to achieve convergence and trust. Nothing will be achieved without time, collaboration, and collective commitment.

Furthermore, it is crucial to open research to a wide public. We need to "go public", to connect our research with public purposes and expectations. To conduct research - and especially comparative research in education - requires an effort of imagination and logic and demands the production of a scientific perspective which we can communicate to others. Lucidity is what we need from education comparatists - a lucidity evident in this book, a book which deserves to be read, discussed, and continued.

António Nóvoa

University of Lisbon

15th December 2017

\section{References}

Cresswell, T. (2010). Towards a politics of mobility. Environment and Planning D: Society and Space, 28, 17-31. 
xiv António Nóvoa

Finger, M., \& Asún, J. M. (2001). Adult Education at the Crossroads - Learning Our Way Out. London: Zed Books.

Illich, I. (1977). Disabling Professions. New York, NY \& London: Marion Boyars.

Labaree, D. (2017). Futures of the field of education. In G. Whitty \& J. Furlong (Eds.), Knowledge and the Study of Education: An International Exploration (pp. 277-283). Oxford: Symposium Books.

Tsing, A. (2005). Friction: An Ethnography of Global Connection. Princeton: Princeton University Press.

Weinberg, M. (2008, 17 August). Interview - Andreas Schleicher. Veja, 20-21. 


\section{Acknowledgements}

We owe our deepest gratitude to all our interviewees for trusting us with their views and making this research possible.

We thank our collaborating professors, Eneida Shiroma, Viktor Bolotov, and Liu Min, whose assistance during the project has been invaluable. The project has also benefited from the formal and informal comments of various academics. It is impossible to name them all; we mention here only Peter DahlerLarsen, Roger Dale, Elina Lahelma, António Nóvoa, Michele Schweisfurth, Martin Thrupp, Igor Valdman, Florian Waldow, and Fan Yihong.

The project was led by Hannu Simola in 2014, and we are grateful for his help in initiating the work. We would also like to thank Heidi Vartiainen for her help as the project coordinator during that time and Anni Klutas, who worked as an intern in the project.

Two anonymous referees for the book's manuscript and three for its synopsis gave us insight in both substantive and communicative aspects, for which we are very grateful.

We would like to thank Rupert Moreton for his work on editing the language of this book.

We of course bear responsibility for any errors and miscommunication.

The project "Transnational Dynamics of Quality Assurance and Evaluation Policies in Brazil, China, and Russia" has been funded by the Academy of Finland during 2014-2017 (grant numbers 307310, 273871, 274218, 273874). We thank the Academy of Finland and its funding programme, The Future of Learning, Knowledge, and Skills TULOS, for giving us this opportunity. 


\section{Contributors}

- Helena Hinke Dobrochinski Candido, University of Tampere (Finland), Faculty of Education, helena.candido@helsinki.fi

- Vera Gorodski Centeno, University of Tampere (Finland), vera.centeno (a) uta.fi

- Galina Gurova, University of Tampere (Finland), Faculty of Education, galina.gurova@gmail.com

- Johanna Kallo, University of Turku (Finland), Department of Education, johanna.kallo@utu.fi

- Jaakko Kauko, University of Tampere (Finland), Faculty of Education, jaakko.kauko@uta.fi

- Anna Medvedeva, University of Tampere (Finland), Faculty of Education, anna.medvedeva@uta.fi

- Romuald Normand, University of Strasbourg (France), rnormand@unis tra.fr

- Nelli Piattoeva, University of Tampere (Finland), Faculty of Education, nelli.piattoeva@uta.fi

- Risto Rinne, University of Turku (Finland), Department of Education, rinne@utu.fi

- Íris Santos, University of Tampere (Finland), Faculty of Education, iris. santos@uta.fi

- Olli Suominen, University of Turku (Finland), Department of Education, opasuo@utu.fi

- Tuomas Takala, University of Tampere (Finland), Faculty of Education, m.tuomas.takala@uta.fi

- Xingguo Zhou, University of Turku (Finland), Department of Education, zhou.xingguo@utu.fi 


\section{Biographies}

Helena Hinke Dobrochinski Candido has a PhD in Political Sociology and a Master's in Regional Development. She is pursuing a second $\mathrm{PhD}$ degree at the University of Helsinki. Her main research interests are education and politics. In her first dissertation, she developed a longitudinal study to investigate youth in Brazil, whereas in her current $\mathrm{PhD}$ research, she explores the political opportunities that quality assurance and evaluation dynamics bring to the subnational level and to schools. Her recent papers and presentations cover quantitative and qualitative analysis of topics such as education governance, quality assurance and evaluation policies, transnational dynamics in education, social inequality, educational trajectories, school failure, and regional development.

Vera G. Centeno, $\mathrm{PhD}$ (Comparative Education, Humboldt-University, Berlin), is a postdoctoral researcher at the University of Tampere. Her dissertation focused on the complexities of early OECD education agendas and investigated agenda-setting and knowledge production within the organisation (Peter Lang, 2017). In her latest research she examined quality-in-education and performance measurement policies (e.g., Comparative Education 54(2), 132-158). Her ongoing projects are about global-local reciprocity in education policy and the involvement of civil society in education politics. Her main research interests are comparative education, school and adult education, bi/multilateralism, transfer and governance, IGOs, quality and assessment, and civil society.

Galina Gurova has MAs in sociology from the Lomonosov Moscow State University, Russia, and education sciences from the University of Oulu, Finland. She is a doctoral candidate at the Faculty of Education, University of Tampere, Finland. Her research interests and publications are in the area of education governance and comparative education, currently focusing on the role and effects of evaluation policies in general education in Russia.

Johanna Kallo, PhD, is Postdoctoral Research Fellow at the Department of Education at the University of Turku and Adjunct Professor at the University of Lapland, Rovaniemi, Finland. Her primary research interest lies in 
comparative education, especially in the education policies of international organizations, higher education, future studies in education, and the contemporary history of the Chinese education system. Her recent publications include "Role of the Organisation for Economic Cooperation and Development (OECD) in the Field of Higher Education Research" (2017) in P. Teixeira and J. C. Shin (eds.), Encyclopedia of International Higher Education Systems and Institutions (Springer) and "Translation of the UNESCO/ OECD Guidelines for Quality Provision in Cross-Border Higher Education into Local Policy Contexts: A Comparative Study on Finland and Russia" (2016) Quality in Higher Education 22(1), 20-35.

Jaakko Kauko, PhD, MSocSc, is Associate Professor of Education at the Faculty of Education, University of Tampere. His research focuses on the fields of education policy and comparative education. He is interested in the questions of power, contingency, and complexity. He is a team leader at the Nordic Centre of Excellence Justice through Education in the Nordic Countries (JustEd). One of his latest publications (2017) is a Routledge monograph co-authored with Hannu Simola, Janne Varjo, Mira Kalalahti, and Fritjof Sahlström titled Dynamics in Education Politics: Understanding and Explaining the Finnish Case.

Anna Medvedeva works as a researcher at the University of Tampere and is a doctoral student at the University of Helsinki. She acquired a master's degree in Studies in European Societies at St Petersburg State University (Russia), focusing on political studies, with an emphasis on the right to education. Her current interests are the internationalisation of higher education, languages in academia, and multicultural education. Her latest publications (2016) include an article co-authored with J. Kauko: "Internationalisation as Marketisation? Tuition Fees for International Students in Finland,' Research in Comparative and International Education 11(1), 98-114.

Romuald Normand is Professor of Sociology at the University of Strasbourg, Faculty of Social Sciences, France (Research Unit SAGE: Societies, Actors and Government in Europe). He works on comparative education policies and politics, Europeanisation, and lifelong learning. Romuald Normand is convenor of the network 28 "Sociologies of European Education" at the European Educational Research Association. He is the head of the Chinese-French Centre for Innovation in Education at the Beijing Normal University, China. He is also a member of the editorial board of the British Journal of Sociology of Education and co-editor of the Routledge series Studies in European Education.

Nelli Piattoeva, PhD, is University Lecturer in education sciences at the University of Tampere, Finland and Adjunct Professor in international and comparative education policy research at the University of Oulu, Finland. Her current research interest focuses principally on the transnationalisation and datafication of education policy. She is particularly concerned with 
national and international large-scale assessments as sources of evidence for policymaking and new technologies of governance at a distance, examining these through the lenses of science and technology studies (STS) and actor-network theory (ANT). Her primary geographical focus of research is Russia and the post-Soviet space.

Íris Santos is a doctoral candidate at the Faculty of Education of the University of Tampere, Finland. She graduated in early childhood education at the University of Évora, Portugal and complemented this with a specialisation in Special Education. In 2013, she completed her master's degree in educational sciences with a specialisation in school management at the Institute of Education of the University of Lisbon, Portugal. Her main research interests are diversity, multiculturalism, education policy, international dynamics, and the intertwinements of the global and national levels in the governance of education. For her PhD, she is analysing the approach of successful countries in the PISA survey as reference societies in the Portuguese education policy discourse.

Risto Rinne is Professor of Education and the Vice-Dean and Head of the Department of Education and the Research Centre (CELE) at the University of Turku, Finland. He is a member of the Finnish Academy of Science and Letters. Rinne has published more than 500 scientific works. His main interests include the sociology of education, international comparative education, education policy, and the history of education. His recent publications (with others) include "Cultural Capital, Equality and Diversifying Education" (2017) in K. Kantasalmi and G. Holm (eds.), The State, Schooling, and Identity: Diversifying education in Europe (Palgrave Macmillan, 149-172) and "Space, Scale and the Governing of Youth Trajectories and Transitions in Europe" (2015) in M. Parreira do Amaral, R. Dale and P. Loncle (eds.), Distributing Life Changes through Governance of Educational Trajectories in Europe (Symposium Books), 43-65.

Olli Suominen, MA, is a doctoral candidate at the Department of Education, University of Turku, Finland. In his ongoing doctoral dissertation, he is examining the teaching of critical thinking skills - namely the teaching of the concept of history politics at different levels of the high school history curriculum in Finland, China, and the United States. In addition to (history) education policy, his future research interests include the contemporary history and politics of China, as well as Vergangenheitsbewältigung - or how societies deal with the (often difficult) past.

Tuomas Takala, Doctor of Social Sciences (sociology), is Professor of Comparative Education (as of 1.1.2018, Professor Emeritus) at the Faculty of Education, University of Tampere. His research has focused on the formation and implementation of education policies in developing countries, particularly on the interface between dependency on external assistance and national policymaking. He has worked as a researcher, guest lecturer, and 


\section{xx Biographies}

short-term expert in Southern and Eastern Africa and South Asia. Between 2000 and 2008, he was an expert member of the Governing Board of the International Institute of Educational Planning and has been a contributor to the EFA Global Monitoring Report.

Xingguo Zhou, MA in pedagogy of higher education (Xiamen University, China), is a doctoral candidate at the University of Turku in the Department of Education. She worked as a lecturer in Minjiang University (2012 to 2014) in Fuzhou, China. Her doctoral dissertation is examining the institutional and discursive transformation of education practices and policies in China, with a special focus on education quality and quality assurance and evaluation. She is also interested in critical theory and critical discourse analysis. 


\title{
1 Comparing politics of quality in education
}

\author{
Jaakko Kauko, Tuomas Takala, and Risto Rinne
}

\section{Introduction}

This book is about understanding the politics of quality in education. Understanding this politics is our goal because the question of quality has become one of the most important framing factors in education policy and practice. It has been of growing interest to international organisations and national policies since at least the 1990s (Leeuw 2002; Power 1994; Smith 1990). We are interested in how the emphasis on quality has changed the basic conditions in which education takes place.

Before it is operationally defined, "quality in education" remains abstract and elusive. Like "choice" or "standards", it may have rhetorical appeal as a generally desirable idea, but it is not until it is put into practice, or "operationalised", that it becomes definable (Kauko et al. 2016; Dahler-Larsen 2015). The same is true for the evaluation of quality. There is little consensus currently even among evaluators as to what constitutes sound evaluation, with some adopting nearly opposite methodological and theoretical stances. (Dahler-Larsen 2012; Grek et al. 2009; Karlsson Vestman \& Segerholm 2009).

Our research seeks to investigate how quality is operationalised and the repercussions this has for the room for action for the different actors involved in education. By actors, we mean the teachers, students, parents, politicians, and civil servants and the organisations they represent who have different room for action, from the local to the global.

We focus on what we call quality assurance and evaluation, QAE (see Ozga et al. 2011). "Quality assurance" implies the need to demonstrate quality (of education) to outsiders (Harvey 2004-17); "evaluation" refers to the general aim of learning and changing current practices, providing "retrospective assessment of public-sector interventions, their organisation, content, implementation and outputs or outcomes, which is intended to play a role in future practical situations" (Vedung 2010). Our definition of QAE is intentionally wide, and it encompasses an array of activities used to evaluate and assure quality, such as student assessment and testing, programme and policy evaluation, school personnel and institutional evaluation, accreditation, curriculum evaluation, selfevaluation, inspection, and auditing (Kellaghan, Stufflebeam, \& Wingate 2003). 
The most common instance of QAE under scrutiny in this book is represented by national large-scale assessments of student achievement.

The importance of understanding QAE is that it is a tool to exercise power (Dahler-Larsen 2015: pp. 29-31), regardless of whether we take a classical view of power as related to resources, attributes, and formal positions (Mills 1956; Dahl 1961; see Bachrach \& Baratz 1962; Lukes 1974) or see it as more relational and structural (e.g., Foucault 2003; Heiskala 2001). Indeed, QAE is a governance tool, which means that procedures intended to enhance quality in education with the help of evaluation are used to achieve political aims, and they shape the power situation of the actors involved.

If one accepts our definition of QAE as a tool of power, it is no surprise that QAE has been embraced in policymaking. For example, international organisations and national governments are greatly optimistic in their use of QAE as a tool of governance. In the field of comparative education, there is vast and growing research into the international and transnational formation of education policy agendas and their influence on policymaking in individual countries (e.g., Chabbott 2002; Mundy 2007; Steiner-Khamsi and Waldow 2012; Verger, Novelli, \& Altinyelken 2012). The concepts of the international and the transnational are even sometimes used interchangeably, but by the former, we mean the actions which happen between national actors or with the help of international organisations, while by the latter, we mean the unofficial and official networks of action and ideas which exist without a restrictive relationship with national borders. Much of the literature mentioned focuses on how international organisations may guide or condition national education policy decisions. They do this by framing policy discussions and providing related technical advice and by prioritising the promise of external funding for projects and sector programmes (e.g., Beech 2006; King 1991).

Rational planning with the help of QAE contrasts with the long tradition of research literature claiming that policymaking never has the grassroots result politicians expect. Studies of the policy process (e.g., Jenkins-Smith \& Sabatier 1993; Baumgartner \& Jones 2009) have pointed out the institutional limitations created by history (Pierson 2000) or norms (March \& Olsen 1989) and drawn on chaotic-sounding notions, such as organised anarchy or "garbage can" (Cohen, March, \& Olsen 1972; Kingdon 2003). In education, there are also many generalising analyses of how reforms fail (e.g., Ball 2001). As Tyack and Cuban (1995) note, it is important to understand how schools act to change intended reforms.

This book is a result of the research project "Transnational Dynamics of Quality Assurance and Evaluation Policies in Brazil, China, and Russia", funded by the Academy of Finland between 2014 and 2017 (grant numbers 307310, 273871, 274218, 273874). During these four years, we conducted 200 interviews with 278 people from different levels of action, conducted observations, and analysed documents. The work was undertaken in three sub-projects, which were responsible for data collection in each country. Crucially, researchers were fluent in the respective national languages of our case countries. 


\section{Our ontological assumptions}

The challenge of policy planning is linked to the book's ontological assumptions the complexity and contingency of the world. We understand them as coherent and overlapping descriptions of the same thing from the perspectives of complexity theory (complexity) and social sciences (contingency). Complexity theories share ideas of systemic behaviour through the interaction of its parts (e.g., emergence and positive and negative feedback), non-linear causation (e.g., partial determination, probabilistic event progression), and different kinds of branching effects (e.g., path dependencies, irreversibility, or punctuated equilibria) (Wimmer 2006; Cairney \& Geyer 2015; Kauko 2014; Room 2015; Biesta \& Osberg 2010). In the social sciences, contingency means that change trajectories are possible but not necessary (Joas 2004; Medd 2002; see Kauko \& Wermke 2018). Politics is thus essentially the organisation and reorganisation of contingency (Kauko 2014; Palonen 1993, 2003, 2006): it is a game in which the basic conditions and constraints for action are defined.

QAE is a good example of the attempt to take political control of complexity. These attempts to channel and control contingency take different shapes. Classically, in political science and complexity theory, a basic limitation is presented by institutions and their formation:

Institutions constrain and channel agent interactions; however, they can also be subverted from below or reformed from above, as actors lift their gaze, reflect upon the overall socio-economic system in which they live and reinforce or reshape the rules and architectures of those systems. This is the stuff of politics and political choice ... It accepts the potential value of modelling social dynamics as a self-organizing system, analogous to those in the natural sciences. On the other hand, it insists that social science must also be centrally interested in the socio-political processes by which these dynamics are re-shaped.

(Room 2015: p. 20)

We attempt to build an understanding of these socio-political processes and their enabling or restriction of the dynamics possible in the discussed setting. This also requires an understanding of history in observing path dependencies (Capano 2009). They indicate how past solutions create a dynamic of increasing returns (Pierson 2000) in which the costs of reversal due to institutional reorganisations grow continually (Levi 1997). These events in history shape the room for political action.

In short, our premises seek to understand the contingent and almost fragile context of political action and how it is always tied to longer-term sociohistorical developments, constrained or enabled by institutional rearrangements, and how actors are both entangled in and empowered by the dynamics which develop in these conditions. 
We have discussed how the ideas of complexity and contingency provide a good basis for not expecting an ideal of a conscious implementation process and have also questioned the ease with which QAE can be used as a governance tool. So, how is it possible to study this phenomenon?

\section{Unpacking policy transfer}

In terms of disciplinary traditions and boundaries, our book could be placed in the fields of comparative education, political science, or even international relations. In some cases, there may be more variance within a discipline than between disciplines. However, our main discussion is largely concerned with the field of comparative education, which influences our discussion across disciplines.

We agree with Rappleye (2012), who argues for a complex understanding of policy transfer and that in a globalising world, the question is crucial. He critically examines the prominent debate which circulates around a large body of system theories like the borrowing and lending theories, which especially analyse the influence of globalisation from the local perspective, and world culture theories, which see convergence in the structures of education systems globally (Rappleye 2012). Borrowing and lending theories study policy diffusion (Steiner-Khamsi 2004: p. 213), ranging from cross-cultural attraction to policy tourism (Steiner-Khamsi 2012). The leading idea of world culture theory is that educational systems around the world are developing in a similar direction structurally mainly as a result of communication amongst international organisations as they diffuse policy blueprints (Meyer, Boli, Thomas \& Ramirez 1997; Ramirez 2012). Disagreement between these views relates to the epistemological understanding of change (Kauko \& Wermke 2018) and the degrees of local and global influence (Rappleye 2012). According to Rappleye (2012: p. 49), the entrenched debate between these two perspectives has led to a "theoretical and conceptual fatigue".

Our research is interested in the effects of what is generally called policy transfer, but we would like to be more specific concerning the causality this implies for these traditions. Waldow (2012) sums up borrowing and lending theories as sharing the ideas of standardisation and legitimation. Standardisation refers to intentional and unintentional movement in a common direction and production of legitimacy to how external references are used to make internal changes or how policies are borrowed from a reference society. World culture theories do not, at least explicitly, consider reference societies but instead look at how nations influenced by world culture start consensually changing their systems towards a common structure (Meyer \& Ramirez 2003). Put simply, in both cases, diffusion bears the idea of a policy moving from one place to another, connoting three things: there must be a "source" (a reference society, international organisation, or "world culture"), there needs to be a recipient, and there needs to be an observable policy (or a "blueprint").

Our premise differs from these usual views of policy transfer. The analytical framework we endorse in this book leads to a disagreement with the notion 
of policy transfer, which in our view cannot cope with a sufficient degree of complexity for a thorough analysis of the process. Instead of discussing questions regarding source and target, global and local, and convergence and divergence, we believe that source and recipient become blurred in networks and flows and understanding the effects of policy transfer, embedded as it is in complex causation, requires theoretical tools to deal with contingencies, path dependencies, and probabilities. Ideas like these have been recognised, for example, under the label of post-structuralist theories (e.g., Larsen \& Beech 2014; Carney 2009) or when Schriewer (2003: p. 20) seeks to understand the "complexity of causal networks".

In analysing interactions between actors, we arrive at an understanding of dynamics as contingent. In the context of policy transfer, complex causation refocuses our analysis from the attempt to understand a policy's source, recipient, and enactment to an attempt to understand the web of factors which exist in a socio-historical situation and sustain a certain dynamic of change. We argue that central questions for analysing quality in education globally are 1) how quality is connected to transnational flows of knowledge and 2) how it offers a powerful governance tool for shaping education for several actors, including for some we would not usually consider.

\section{The transnational agenda of QAE}

Given our starting points, QAE in education offers a fruitful point for analysis, because it brings to the fore the theoretical aspects in which we are interested. QAE is a gateway to understanding transnational flows, because international and national actors use it as a tool of governance: measurement in education facilitates the creation of categories for the performance of individuals or organisations and for making decisions (Fenwick, Mangez, \& Ozga 2014).

The increased role of knowledge and data management in the making of education policy has been analysed as a recent development in the modes of governance (Carvalho 2013; Fenwick, Mangez, \& Ozga 2014; Lawn \& Segerholm 2011). As part of this change policy, advice has increasingly conveyed messages of "international best practice". Organisations such as the World Bank and the Organisation for Economic Cooperation and Development (OECD) have had an important role in the dissemination of these policies. These international organisations can be characterised as "epistemic communities" drawing on the knowledge dependency created by the increasing requirements for decisionmakers to deal with a broader range of issues in the expanding global economy and the consequent need for external advice (Armingeon \& Beyeler 2004; Haas 1992; Hasenclever, Mayer, \& Rittberger 2002; Kallo 2009: p. 357).

Our analysis of QAE is restricted to general school education (i.e., it excludes vocational and tertiary education). The transnational agenda around QAE is constructed within a network of actors which have no clear boundaries or identifiable centre of power or thought from which the agenda emanates. The network shares a common belief in the necessity of measuring learning outcomes as a key precondition for improving education quality worldwide 
(e.g., UNESCO Institute of Statistics 2013: pp. 14-16; World Bank 2013: p. 4; Center for Global Development 2013). Actors within the network consist of a wide range of multilateral organisations, for example, the World Bank; the OECD; the United Nations Educational, Scientific and Cultural Organisation (UNESCO); regional networks, such as the Latin American Laboratory for the Assessment of Quality in Education (LLECE) and the Southern African Consortium for the Measurement of Education Quality (SACMEQ); private professional bodies (the Brookings Institute, Educational Testing Services); academic experts; and consultants.

The policies of the three principal education-related international organisations relevant to QAE - the World Bank, UNESCO, and the OECD - vary in how their assistance is tied to money flows and the extent to which national and local actors are able to set the agenda. Whereas the World Bank is perceived as leaning towards a harder policy line, with leverage provided by its lending operations, the OECD has authority without financial clout, and UNESCO has been reduced to a relatively weak policy actor (Henry et al. 2001: pp. 17-18; Rinne \& Ozga 2011). While these organisations have different agendas, especially the World Bank and the OECD, and to an extent UNESCO, they share a similar toolkit: "a range of instruments that can be targeted at national policies: they can promote, develop and disseminate policies, coordinate, set standards, supply technical assistance and offer financial inducements" (Rinne \& Ozga 2013: p. 98).

The improvement of education quality can of course be justified by reference to any objective set for the education system. In contrast, the typical justification expressed for the transnational assessment agenda is notably narrow and even monotonous: reference is made in numerous sources to the finding that cognitive learning achievement - rather than years of schooling per se - has a positive impact on economic growth (original research paper by Hanushek \& Woessmann 2007; references, e.g., World Bank 2011: p. 24; Center for Global Development 2013: pp. 3-4). The corollary is that a well-functioning system of assessing learning outcomes is "a key driver of economic growth and poverty reduction” (READ 2010: p. 36).

The "problematisation" and overall policy advice on QAE in general school education found in the global World Bank documents in the past two decades illustrates the substance of the transnational agenda:

1) The principal goal of education is seen as contributing to economic growth and poverty reduction.

2) This contribution is crucially dependent on the quality of education.

3) There is mounting evidence from international assessments that the quality of education is low in many countries.

4) Information on learning achievement is needed both for monitoring education quality as a basis for policy decisions and for increased accountability of schools towards parents, communities, and donor agencies; such information should then provide incentives for improving quality.

5) The case is then made for the establishment of national assessment systems and wider participation in international assessments and related capacity 
building; to these, the World Bank and other agencies should provide support (World Bank 1995: pp. 1-3, 9, 15; 1999: pp. iii, vii-ix; 2005: pp. 12, 67-69; 2011: pp. 6-8).

The role of the OECD derives from its knowledge-production capacity. It is thought to have a central role in the flow of international educational ideas and in the governance of education (Rinne \& Ozga 2011), and the market-liberal ideological undercurrents in knowledge-making have also been noted (Dale 1999: pp. 1-4; Dale \& Robertson 2002: p. 11). The OECD's central role in setting international benchmarks makes it a broker of the main currency in the global education setting, which national policymakers usually see as a global competition (Lauder et al. 2006: p. 41; Robertson, Bonal Dale. 2002; Rinne, Kallo \& Hokka. 2004; Rinne \& Ozga 2011). The OECD's annual compendium, "Education at a Glance", has become a statistical "doxa", just as the PISA survey (Programme for International Student Assessment) and its indicators, rankings, and league tables are often taken as objective indicators which point the way to the improvement of results and placings in rankings in national educational policy (Rinne et al. 2004; Rinne \& Ozga 2011). Initially confined to OECD member countries, the PISA programme has been gradually expanded to non-member countries - including Brazil, China, and Russia - which share a history of having been clients of the World Bank. For such countries, this represents a significant symbolic upgrading of their international status.

The research on global agendas in education is nuanced and complex and deals with many of the basic problematics in the comparative education field (Verger, Novelli, \& Altinyelken 2012), which tend to emphasise the importance of international and transnational changes and their reshaping of the role of the state (Werner \& Zimmermann 2006; Robertson, Bonal, \& Dale 2002). Structurally, research seems to indicate the state's diminishing role as an education actor in the face of globalisation. The state is, on one hand, riddled with transnational influences, while, on the other, the global QAE agenda allows less independence. Where action is concerned, the content of the transnational QAE agenda seems to ignore the political undercurrents of QAE - the negotiations, interpretations, and difficulties highlighted in the above-mentioned research tradition concerning policymaking and governance. Using our analytical framework, we would expect to find more contingency and room for action in how transnational QAE data are used. We also analyse Russia and China, in which the state is heavily involved, thus critically examining the discussion of the state's diminishing importance.

\section{Comparing dynamics in education politics in Brazil, China, and Russia}

The case countries in our research are Brazil, China, and Russia. Their historical trajectories are described in more detail in Chapter 3. Here it is sufficient to mention that they present a clear set of common features which justify their selection for a comparative study. The term BRICS, coined in the new 
millennium (O’Neill 2001; Hurrel 2006) and applied to these three "emerging economies", along with India and South Africa, has been adopted by the case countries themselves, suggesting their global ambitions are somewhat similar. Brazil, China, and Russia aspire to regional leadership and leverage their economic and political positions through social policies, including education. Like other countries, they have increasingly focused on QAE in education (Chin 2012; Hurrel 2006; Lima 2012; Piattoeva \& Takala 2014; Rowlands 2012). In these three contexts, we analyse how QAE works in transnational networks, how data circulate, how QAE functions as a governance tool, and how all this affects the room for action available to different actors.

The terms "framework", "theory", and "model" are sometimes used interchangeably, but we follow Elinor Ostrom (2005: pp. 27-28), who understands them as nested. With the help of a framework, it is possible to loosely identify the essential elements for analysis: "They attempt to identify the universal elements that any relevant theory would need to include ... [E]lements contained in a framework help the analyst generate the questions that need to be addressed when first conducting an analysis" (Ostrom 2005: p. 28). Theory helps to focus the view further in making more specific assumptions: "a scholar needs to select one or more theories to use in generating predictions about expected patterns of relationships" (Ostrom 2005: p. 28). Models make more precise assumptions concerning a theory's sub-section. However, this is beyond the focus of our research. To understand QAE in education in the transnational context, we start our analysis with an analytical framework called Comparative Analytics of Dynamics in Education Politics (CADEP) (see Kauko et al. 2015; Simola et al. 2017). This idea is further refined with compatible theories in the subsequent chapters.

Using CADEP, we hope to tease out comparable and related patterns of action. Our framework's first word, "comparative", indicates that we analyse homologies between the different contexts. The second word, "analytics", indicates that we are interested in understanding actors' room for action. By focusing on "dynamics in education politics", we stress the importance of analysing the actual movement of the education system rather than focusing on actors' attributes. We thus shed light on the limits and possibilities for action on different levels. Simola et al. (2017) describe the dynamics in education politics as follows:

In many cases it [dynamics in education] is a result of contingencies in history, and is currently sustained by political action on different levels or that is constantly subjected to transnational flows. The action itself, regardless of whether or not it is considered political, derives from societal thought structures, is questioned or unquestioned, happens in the course of time, is connected to resources and past events, passes, and creates room for future action. What is called equality, trust, or progress is manifested through action, described here in terms of relational and contingent dynamics. 
To sum up, in attempting to grasp the multifaceted nature of both QAE and transnational flows, we share many of the ontological and epistemological premises of complexity theories. We emphasise the contingent nature of the world, the fact that events and change are possible but not necessary. Described in more detail in the next chapter, the three dimensions of the CADEP framework are derived from a vast conceptual-historical project (Palonen 2003, 2006) and analysis of the policy process (Kingdon 2003; Baumgartner \& Jones 2009; Sabatier \& Jenkins-Smith 1993).

- Political situation relates to the changing political constellations of actors associated with education quality and their effect on what is structurally possible on different scales of action.

- Analysis of political possibilities happens through the dominant discourses: what the relevant actors consider possible or what they consider to be the problem.

- The third dimension is the use of the political space. It relates to how the actors use the room for action created by the first two dimensions.

With the help of these three dimensions, our aim is to analyse how QAE as a transnational flow and governance tool changes the role of state, expertise, and governance and the room for action which exists for politicians, teachers, and other actors in varying contexts.

\section{The structure of the book}

Chapter 2 discusses the theoretical and analytical premises of our research and aims to increase its validity through methodological transparency. It draws on the idea of reflective research and discusses the questions of case selection and comparability, as well as the concrete work of data collection and analysis. Research journey narratives are used to consider field access and ethical issues and to produce another layer of research data about the manifestations of QAE. The chapter also reflects on the differences in data availability in the three countries and the limitations this poses for comparative analysis. To compare the dynamics which emerge in QAE policies in the different contexts, the chapter introduces the CADEP analytical framework in more depth and discusses the abductive research design, in which theoretical and empirical work are complementary.

Chapter 3 analyses the socio-historical background necessary for an understanding of the development of QAE policies in the three countries and for an analysis of the problematics in the following chapters. It outlines the historical paths of the development of QAE policies in each context during the postWorld War II period. First, it presents a case-by-case chronological account of these trajectories, based on document analysis and literature review; then it proceeds to a comparative analysis.

Chapter 4 is the first to use data from our fieldwork. Following the analytical framework, it analyses the changing national political arena in the Brazilian, 
Chinese, and Russian contexts. In this chapter, we ask how QAE has changed the roles of national and international actors in policymaking. We analyse interviews with representatives of international and national organisations and with individual actors and use document analysis as background material. We demonstrate that enhanced data infrastructure and expertise, along with other resources, have made national governments less dependent on international organisations, while remaining more interested in and interlinked with international trends.

Chapter 5 describes and analyses the changing roles of and relationship between the state and expertise in Brazil, China, and Russia. National policies aim to determine the development and application of QAE instruments as they empower state governance. However, the data generated are also strongly dependent on experts. In analysing interview data from experts, civil servants, politicians, and other stakeholders, we aim to discover who is considered a legitimate collector and analyst of QAE data. We find that a growing number of state-controlled systems allow experts some room for action but that state approval continues to serve as the main source of legitimation.

Chapter 6 discusses the concept of governance at a distance as a new form of governance in relation to the book's analytical framework. The expanding practices of QAE produce quantitative data about education which is said to allow the nation-state to extend its capacity to govern across territory and into the classroom. Governance at a distance relies on the production and circulation of data. This chapter focuses on the tensions and paradoxes which appear to make the process of governance at a distance through data less smooth than is generally depicted in both academic literature and political rhetoric. We first analyse official policy statements concerning where data are presumed to circulate and for what purpose. We then use interview data to explore the paradoxes emerging from the political objectives of data circulation and use and from the paradoxical nature of quantitative data about education itself.

Chapter 7 investigates the ways in which local authorities utilise QAE policies to govern schools and the effects this has on their room for action. The analysis draws on a combination of governance theories and on the political frame of organisational analysis. The fieldwork data were collected in selected localities in Brazil, China, and Russia by means of document analysis, interviews, and observations. We demonstrate that the QAE instruments are reinterpreted locally in accordance with the pre-existing practices of quality control and school governance and are biased towards local actors' political interests. Highperforming schools can thus utilise QAE policies to draw power from sources such as expertise, access to agenda setting, or building networks and coalitions, while low performers are increasingly disadvantaged. Schools' reputations act as a key to the virtuous or vicious cycles in which schools find themselves ensnared in the implementation of performance evaluation. Our findings also indicate that the room for action for those schools opposing new QAE policies is somewhat restricted. However, schools can practise hidden resistance and to a certain extent avoid the penetration of QAE tools into their internal processes. 
Chapter 8 analyses alternative futures of QAE as expressed by Brazilian, Chinese, and Russian actors. We use official policy documents and our interview data to investigate how national officials and experts see the future of QAE in their respective contexts and the trends they perceive as preferable or undesirable. Our findings are set against the backdrop of the case countries' socio-cultural history. We also compare the views expressed in interviews to a typology of future scenarios for societies and education. In addition to the envisioned "new" futures, we also find views of alternative futures which are rooted in domestic pedagogical traditions, including QAE practices, and express the desire to retain what the interviewees see as valuable in these traditions.

Chapter 9 draws together the main findings of our research and reflects on their theoretical significance. We conclude that there are three dynamics in the politics of quality in Brazil, China, and Russia. Self-reinforcing and shared goalsetting reflect how QAE has overtaken quality as a goal of education policy. Authorising but diverted governance describes how QAE enables a parallel trend of authorising more governance methods, while creating increasingly complex systems. Destabilising and reorganising role-setting indicates how the mechanisms of QAE create new actors in the field, which at the same time brings instability to the political system because of the potential of QAE data to provoke change.

\section{About our research and writing}

Many of the questions covered by this book have been dealt with extensively in the project's previously published or submitted articles. Reference to these is made in the chapters where relevant, and the respective bibliographical information is found in the chapters' reference lists.

The project consortium, led by Associate Professor Jaakko Kauko, consisted of three sub-projects, each responsible for investigating one of the case countries. The leaders of the sub-projects, who are also editors of this book, were Jaakko Kauko for the Brazil sub-project, Professor Risto Rinne for China, and Professor Tuomas Takala for Russia. The individual chapters' author teams worked in the sub-projects in varying roles (document analysis, interviews at different levels, fieldwork at the local level) and with varying total workloads. The researchers in the three sub-projects were

- Brazil: DrVera Gorodski Centeno, Dr Helena Hinke Dobrochinski Candido, Íris Santos

- China: Dr Johanna Kallo, Olli Suominen, Xingguo Zhou

- Russia: Dr Nelli Piattoeva, Galina Gurova, Anna Medvedeva

The project also benefited from valuable advice and support from three collaborating professors: Viktor Bolotov (Higher School of Economics, Moscow), Liu Min (Beijing Normal University), and Eneida Shiroma (Federal University of Santa Catarina). We also invited Professor Romuald Normand (University of Strasbourg) to contribute to one of the chapters. 


\section{Jaakko Kauko et al.}

The project's work mode was a combination of the individual responsibilities first defined in the project plan and subsequently adjusted in the course of its implementation and frequent internal communication and intensive periodic workshops. Thus, the designation of individual members of the project teams as authors of chapters can only express the division of responsibilities in the writing process: it does not fully reflect all the individual contributions to the intellectual process of our data analysis which underpinned the writing of this book.

\section{Bibliography}

Adams, D. (1993). Defining Educational Quality (IEQ Publications No. 1). Pittsburgh: University of Pittsburgh.

Alasuutari, P. (2009). The domestication of worldwide policy models. Ethnologia Europaea, 39(1), 66-71.

Alvesson, M., \& Sköldberg, K. (2009). Reflexive Methodology: New Vistas for Qualitative Research (2nd ed.). London: Sage.

Anderson-Levitt, K. M. (2012). Complicating the concept of culture. Comparative Education, 48(4), 441-445.

Armingeon, K., \& Beyeler, M. (Eds.). (2004). The OECD and European Welfare States. Northampton: Edward Elgar Publishing, Inc.Bachrach, P., \& Baratz, M. S. (1962). Two faces of power. The American Political Science Review, 56(4), 947-952.

Ball, S. J. (2001). Global policies and vernacular politics in education. Currículo Sem Fronteiras, 1(2), xxvii-xliii.

Ball, S. J. (2012). Global Education Inc.: New Policy Networks and the Neoliberal Imaginary. London \& New York, NY: Routledge.

Baumgartner, F. R., \& Jones, B. D. (2009). Agendas and Instability in American Politics (2nd ed.). Chicago, IL: Chicago University Press.

Beech, J. (2006). Redefining Educational Transfer: International Agencies and the (Re)production of Educational Ideas. In J. Sprogoe \& T. Winter-Jensen (Eds.), Identity, Education and Citizenship - Multiple Interrelations. Frankfurt am Main: Peter Lang.

Biesta, G., \& Osberg, D. (2010). Complexity, education and politics from the inside-out and the outside-in: An introduction. In D. Osberg \& G. Biesta (Eds.), Complexity Theory and the Politics of Education (pp. 1-4). Rotterdam: Sense Publishers.

Cairney, P., \& Geyer, R. (2015). Introduction. In R. Geyer \& P. Cairney (Eds.), Handbook on Complexity and Public Policy (pp. 1-15). Cheltenham: Edward Elgar Publishing.

Capano, G. (2009). Understanding policy change as an epistemological and theoretical problem. Journal of Comparative Policy Analysis: Research and Practice, 11(1), 7-31.

Carney, S. (2009). Negotiating policy in an age of globalization: Exploring educational "Policyscapes" in Denmark, Nepal, and China. Comparative Education Review, 53(1), 63-68.

Carvalho, L. M. (2013). The fabrications and travels of a knowledge-policy instrument. European Educational Research Journal, 11(2), 172-188.

Center for Global Development. (2013). Schooling Is Not Education! - Using Assessment to Change the Politics of Non-Learning. Retrieved December 21, 2017, from www.cgdev.org/ doc/full_text/CGDReports/3120290/schooling-is-not-education.html

Chabbott, C. (2002). Constructing Education for Development - International Organizations and Education for All. New York, NY: Routledge \& Falmer.

Chin, G. (2012). Two-way socialization: China, the World Bank, and Hegemonic weakening. Brown Journal of World Affairs, 19(1), 211-230.

Cohen, M. D., March, J. G., \& Olsen, J. P. (1972). A garbage can model of organizational choice. Administrative Science Quarterly, 17(1), 1-25. 
Dahl, R. A. (1961). Who Governs? New Haven: Yale University Press.

Dahler-Larsen, P. (2011). Afterword. In O. Jenny, D.-L. Peter, S. Christina, \& S. Hannu (Eds.), Fabricating Quality in Education: Data and Governance in Europe (pp. 151-159). London: Routledge.

Dahler-Larsen, P. (2012). Constitutive effects as a social accomplishment: A qualitative study of the political in testing. Educational Inquiry, 3(2), 171-186.

Dahler-Larsen, P. (2015). The evaluation society: Critique, contestability and skepticism. SpazioFilosofico, 1, 21-36.

Dale, R. (1999). Specifying globalization effects on national policy: a focus on the mechanisms. Journal of Education Policy, 14(1), 1-17.

Dale, R., \& Robertson, S. L. (2002). The varying effects of regional organizations as subjects of globalization of education. Comparative Education Review, 46(1), 10-36.

Fejes, A. (2006). The Bologna process - governing higher education in Europe through standardisation. Revista Española de Educación Comparada, 12, 203-231.

Fenwick, T., Mangez, E., \& Ozga, J. (2014). Governing Knowledge: Comparison, KnowledgeBased Technologies and Expertise in the Regulation of Education. London: Routledge.

Foucault, M. (2003). Society Must Be Defended: Lectures at the Collegge de France, 1975-1976. New York, NY: Picador.

Grek, S., Lawn, M., Lingard, B., \& Varjo, J. (2009). North by northwest: Quality assurance and evaluation processes in European education. Journal of Education Policy, 24(2), $121-133$.

Grek, S., \& Rinne, R. (2011). Fabricating Europe. In J. Ozga, P. Dahler-Larsen, C. Segerholm, \& H. Simola (Eds.), Fabricating Quality in Education: Data and Governance in Europe (pp. 19-31). London: Routledge.

Haas, P. (1992). Introduction: Epistemic communities and international policy coordination. International Organisation, 46(1), 1-35.

Hanushek, E. A., \& Woessmann, L. (2007). The role of education quality for economic growth (Policy Research Working Paper No. 4122). Washington, DC: World Bank.

Harvey, L. (2004-2017). Analytic quality glossary. Quality Research International. Retrieved from www.qualityresearchinternational.com/glossary/

Hasenclever, A., Mayer, P., \& Rittberger, V. (2002). Theories of International Regimes (5th ed.). Cambridge Studies in International Relations 55. Cambridge: Cambridge University Press.

Hedström, P., \& Wittrock, B. (2009). Introduction: Frontiers of sociology. In P. Hedström \& B. Wittrock (Eds.), Frontiers of Sociology (pp. 1-11). Leiden: Koninklijke Brill.

Heiskala, R. (2001). Theorizing power: Weber, Parsons, Foucault and neostructuralism. Social Science Information, 40(2), 241-264.

Held, D., McGrew, A., Goldblatt, D., \& Perraton, J. (1999). Global Transformations: Politics, Economics and Culture. Stanford: Stanford University Press.

Henry, M., Lingard, B., Rizvi, F., \& Taylor, S. (2001). The OECD, Globalization and Education Policy. Oxford: International Association of Universities.

Hurrel, A. (2006). Hegemony, liberalism and global order: What space for would-be great powers? International Affairs, 82(1), 1-19.

Jenkins-Smith, H. C., \& Sabatier, P. A. (1993). The study of public policy processes. In H. C. Jenkins-Smith \& P. A. Sabatier (Eds.), Policy Change and Learning: An Advocacy Coalition Approach (pp. 1-9). Boulder, CO: Westview Press.

Joas, H. (2004). Morality in an age of contingency. Acta Sociologica, 47(4), 392-399.

Kallo, J. (2009). OECD Education Policy. A Comparative and Historical Study Focusing on the Thematic Reviews of Tertiary Education. FERA: Jyväskylä.

Karlsson Vestman, O., \& Segerholm, C. (2009). Dialogue, deliberation and democracy in educational evaluation - theoretical arguments and a case narrative. In The SAGE Handbook of Educational Evaluation (pp. 465-482). London: Sage. 
Kauko, J. (2013). Dynamics in higher education politics: A theoretical model. Higher Education, 65(2), 193-206.

Kauko, J. (2014). Complexity in higher education politics: Bifurcations, choices and irreversibility. Studies in Higher Education, 39(9), 1683-1699.

Kauko, J., Centeno, V. G., Candido, H., Shiroma, E., \& Klutas, A. (2016). The emergence of quality assessment in Brazilian basic education. European Educational Research Journal, 15(5), 558-579.

Kauko, J., Corvalán, J., Simola, H., \& Carrasco, A. (2015). Historical dynamics in Chilean and Finnish basic education politics. In P. Seppänen, A. Carrasco, M. Kalalahti, R. Rinne, \& H. Simola (Eds.), Contrasting Dynamics in Education Politics of Extremes: School Choice in Chile and Finland (pp. 29-52). Rotterdam: Sense Publishers.

Kauko, J., \& Wermke, W. (2018). The contingent sense-making of contingency: Epistemologies of change in comparative education. Comparative Education Review 62(2).

Kellaghan, T., Stufflebeam, D., \& Wingate, L. (2003). Introduction. In T. Kellaghan \& D. Stufflebeam (Eds.), International Handbook of Educational Evaluation (pp. 1-6). Dordrecth: Kluwer Academic Publishers.

King, K. (1991). Aid and Education in the Developing World - the Role of the Donor Agencies in Educational Analysis. Harlow: Longman.

Kingdon, J. W. (2003). Agendas, Alternatives, and Public Policies (2nd ed.). New York, NY: Longman.

Larsen, M. A., \& Beech, J. (2014). Spatial theorizing in comparative and international education research. Comparative Education Review, 58(2), 191-214.

Lauder, H., Brown, P., Dillabough, J-A., \& Halsey, A. H. (Eds.). (2006). Education, Globalization \& Social Change. Oxford: Oxford University Press.

Lawn, M., \& Segerholm, C. (2011). Europe through experts and technologies. In J. Ozga, P. Dahler-Larsen, C. Segerholm, \& H. Simola (Eds.), Fabricating Quality in Education: Data and Governance in Europe (pp. 32-46). London: Routledge.

Leeuw, F. L. (2002). Evaluation in Europe 2000: Challenges to a growth industry. Evaluation, $8(1), 5-12$.

Levi, M. (1997). A model, a method, and a map: Rational choice and historical analysis. In M. Lichbach \& A. Zuckerman (Eds.), Comparative Politics: Rationality, Culture and Structure (pp. 19-41). Cambridge: Cambridge University Press.

Lima, M. C. (2012). O Brasil, os BRICS e a agenda internacional [Brazil, BRICS and an international agenda]. FUNAG, 153-174.

Lukes, S. (1974). Power: A Radical View. London: Palgrave Macmillan.March, J. G., \& Olsen, J. P. (1989). Rediscovering Institutions: The Organizational Basis of Politics. New York, NY: Free Press.

Medd, W. 2002. Complexity and the social world. International Journal of Social Research Methodology, 5(1), 71-81.

Meyer, J. W., Boli, J., Thomas, G. M., \& Ramirez, F. O. (1997). World society and the nation-state. American Journal of Sociology, 103(1), 114-181.

Meyer, J. W., \& Ramirez, F. O. (2003). The world institutionalization of education. In J. Schriewer (Ed.), Discourse Formation in Comparative Education (pp. 111-132). Frankfurt am Main: Peter Lang.

Mills, C. W. (1956). The Power Elite. New York, NY \& Oxford: Oxford University Press.

Mundy, K. (2007). Global governance, educational change. Comparative Education, 43(3), $339-357$.

Nóvoa, A., \& Yariv-Mashal, T. (2003). Comparative research in education: A mode of governance or a historical journey? Comparative Education, 39, 423-439. 
O'Neill, J. (2001). Building better global economic BRICs. Goldman Sachs Inc. Retrieved June 9, 2013, from www.goldmansachs.com/our-thinking/archive/archive-pdfs/buildbetter-brics.pdf

Ostrom, E. (2005). Understanding Institutional Diversity. Princeton, NJ: Princeton University Press.

Ozga, J., Dahler-Larsen, P., Segerholm, C., \& Simola, H. (2011). Introduction. In J. Ozga, P. Dahler-Larsen, C. Segerholm, \& H. Simola (Eds.), Fabricating Quality in Education: Data and Governance in Europe (pp. 1-8). London: Routledge.

Ozga, J., \& Jones, R. (2006). Travelling and embedded policy: The case of knowledge transfer. Journal of Education Policy, 21(1), 1-17.

Palonen, K. (1993). Introduction: From policy and polity to politicking and politicization. In K. Palonen \& T. Parvikko (Eds.), Reading the Political: Exploring the Margins of Politics (pp. 6-16). Helsinki: Finnish Political Science Association.

Palonen, K. (2003). Four times of politics: Policy, polity, politicking, and politicization. Alternatives, 28, 171-186.

Palonen, K. (2006). The Struggle With Time: A Conceptual History of "Politics" as an Activity. Hamburg: Verlag Münster.

Pereyra, M. A. (2008). Preface. In M. A. Pereyra (Eds.), Changing Knowledge and Education. Communities, Mobilities, and New Policies in Global Societies (pp. 5-17). Frankfurt am Main: Peter Lang.

Piattoeva, N., \& Takala, T. (2014). Russia as a returning donor - four roles in development assistance to education. Globalisation, Societies and Education, 13(3), 388-410.

Pierson, P. (2000). Increasing returns, path dependence, and the study of politics. The American Political Science Review, 94(2), 251-267.

Power, M. (1994). The Audit Explosion. London: Demos.

Qadir, A. (2014). Culture and history in the domestication of global trends of higher education in Pakistan. In P. Alasuutari \& A. Qadir (Eds.), National Policy-Making: Domestication of Global Trends (pp. 147-163). London: Routledge.

Ramirez, F. O. (2012). The world society perspective: Concepts, assumptions, and strategies. Comparative Education, 48(4), 423-439.

Rappleye, J. (2012). Educational Policy Transfer in an Era of Globalisation: Theory - History Comparison. Frankfurt am Main: Peter Lang.

Rautalin, M. (2014). The role of PISA publicity in forming national education policy: The case of Finnish curriculum reform. In P. Alasuutari \& A. Qadir (Eds.), National PolicyMaking: Domestication of Global Trends (pp. 95-110). London: Routledge.

READ. (2010). READ annual report 2009. Russia Education Aid for Development (READ) Trust Fund. Retrieved December 21, 2017, http://siteresources.worldbank.org/ INTREAD/Resources/READ_AnnualReport_2009_web.pdf

Rinne, R., Kallo, J., \& Hokka, S. (2004). Too eager to comply - OECD education policies and the Finnish response. European Educational Research Journal, 3(2), 454-485.

Rinne, R., \& Ozga, J. (2011). Europe and the global: The role of the OECD in education politics. In O. Jenny, D.-L. Peter, S. Christina, \& S. Hannu (Eds.), Fabricating Quality in Education: Data and Governance in Europe (pp. 66-75, 151-159). London: Routledge.

Rinne, R., \& Ozga, J. (2013). The OECD and the global re-regulation of teacher's work knowledge-based regulation tools and teachers in Finland and England. In T. Seddon \& J. S. Levin (Eds.), Educators, Professionalism and Politics: Global Transitions, National Spaces and Professional Projects. World Yearbook of Education 2013. New York, NY: Routledge.

Robertson, S. L., Bonal, X., \& Dale, R. (2002). GATS and the education service industry: The politics of scale and global reterritorialization. Comparative Education Review, 46(4), 472-495. 


\section{Jaakko Kauko et al.}

Room, G. (2015). Complexity, power and policy. In R. Geyer \& P. Cairney (Eds.), Handbook on Complexity and Public Policy (pp. 19-31). Cheltenham: Edward Elgar Publishing.

Rowlands, D. (2012). Individual BRICS or a collective bloc? Convergence and divergence amongst "Emerging Donor" nations. Cambridge Review of International Affairs, 25(4), 629-649.

Sabatier, P. A., \& Jenkins-Smith, H. C. (1993). The advocacy coalition framework: Assessment, revisions, and implications for scholars and practitioners. In P. A. Sabatier \& H. C. Jenkins-Smith (Eds.), Policy Change and Learning. An Advocacy Coalition Approach (pp. 211235). Boulder, CO: Westview Press.

Schriewer, J. (2003). Comparative education methodology in transition: Towards a science of complexity? In J. Schriewer (Ed.), Discourse Formation in Comparative Education (pp. 3-52). Frankfurt am Main: Peter Lang.

Simola, H., Kauko, J., Varjo, J., Kalalahti, M., \& Sahlström, F. (2017). Dynamics in Education Politics - Understanding and Explaining the Finnish Case. London: Routledge.

Simola, H., Rinne, R., Varjo, J., \& Kauko, J. (2013, January 16). The paradox of the education race: How to win the ranking game by sailing to headwind. Journal of Education Policy.

Smith, D. (1990). Assessment, technology and the quality revolution. In T. Schuler (Eds.), World Yearbook of Education 1990: Assessment and Evaluation (pp. 41-55). London: Kogan Page.

Steiner-Khamsi, G. (2004). Blazing a trail for policy theory and practice. In G. SteinerKhamsi (Ed.), The Global Politics of Educational Borrowing and Lending (pp. 201-220). New York, NY \& London: Teachers College, Columbia University.

Steiner-Khamsi, G. (2012). Understanding policy borrowing and lending: Building comparative policy studies. In G. Steiner-Khamsi \& F. Waldow (Eds.), Policy Borrowing and Lending in Education. World Yearbook of Education 2012 (pp. 1-17). London \& New York, NY: Routledge.

Steiner-Khamsi, G. (2014). Comparison and context: The interdisciplinary approach to the comparative study of education. Current Issues in Comparative Education, 16(2).

Steiner-Khamsi, G., \& Waldow, F. (Eds.). (2012). Policy Borrowing and Lending in Education. World Yearbook of Education 2012. London \& New York, NY: Routledge.

Stromquist, N. P. (2007). Qualidade de ensino e gênero nas políticas educacionais contemporâneas na América Latina. Educação e Pesquisa, 33(1).

Tyack, D., \& Cuban, L. (1995). Tinkering toward Utopia: A Century of Public School Reform. Cambridge, MA: Harvard University Press.

UNESCO Institute of Statistics and Center for Universal Education at Brookings Institute. (2013). Towards Universal Learning - Recommendations From the Learning Metrics Task Force. Retrieved December 21, 2017, from www.uis.unesco.org/Education/Documents/lmtfsummary-rpt-en.pdf

Vedung, E. (2010). Four waves of evaluation diffusion. Evaluation, 16(3), 263-377.

Verger, A., Novelli, M., \& Altinyelken, K. (2012). Global education policy and international development: An introductory framework. In A. Verger, M. Novelli, \& K. Altinyelken (Eds.), Global Education Policy and International Development: New Agendas, Issues and Policies. London: Continuum.

Waldow, F. (2012). Standardisation and legitimacy: Two central concepts in research on educational borrowing and lending. In G. Steiner-Khamsi \& F. Waldow (Eds.), Policy Borrowing and Lending in Education. World Yearbook of Education 2012 (pp. 411-427). London \& New York, NY: Routledge.

Walters, W., \& Haahr, J. H. (2005). Governing Europe: Discourse, Governmentality and European Integration. Abingdon: Routledge. 
Werner, M., \& Zimmermann, B. (2006). Beyond comparison: "Histoire Croisée" and the challenge of reflexivity. History and Theory, 45(1), 30-50.

Wimmer, A. (2006). Models, methodologies, and metaphors on the move. In A. Wimmer \& R. Kössler (Eds.), Understanding Change: Models, Methodologies, and Metaphors (pp. 1-36). Houndmills: Palgrave Macmillan.

World Bank. (1995). Priorities and Strategies for Education - a World Bank Review. Washington, DC: World Bank.

World Bank. (1999). Education Sector Strategy. Washington, DC: World Bank.

World Bank. (2005). Education Sector Update. Washington, DC: World Bank.

World Bank. (2011). Learning for All 2020 - World Bank Group Education Strategy. Washington, DC: World Bank.

World Bank. (2013). Developing Skills for Innovative Growth in the Russian Federation. Washington, DC: World Bank. 


\title{
2 Layers of reflectivity in comparative research
}

\author{
Jaakko Kauko, Vera Gorodski Centeno, \\ Nelli Piattoeva, Helena Candido, Galina Gurova, \\ Anna Medvedeva, Íris Santos, Olli Suominen, \\ and Xingguo Zhou
}

\section{Introduction: reflective research}

One of our research project's assumptions is that the topic of quality assurance and evaluation (QAE) is political: it is an important framing factor for education, a major interest for many different stakeholders, and a governance tool (Nóvoa \& Yariv-Mashal 2003). In this respect, it is possible that our research will be used for political purposes, an aspect most of our research participants and fellow researchers certainly recognise. Self-reflection is therefore essential.

In Chapter 1, we discussed our ontological and epistemological premises and how the analytical framework on which we draw, Comparative Analytics of Dynamics in Education Politics (CADEP), directs our focus to three dimensions we see as relevant for an understanding of the questions raised in complexity studies and the approaches of political science to contingency. While the previous chapter addressed the "why" question of our research, here we open more broadly the questions "how" and "what". There is no simple answer to these questions, because the shared view of scholars is that research is never as straightforward as research reports describe - and in this respect, this book is no exception. Our research journey has taken a route with paths, streets, cul-de-sacs, and wanderings through uncharted territories. As a research consortium, we have held CADEP as a compass, while continuously debating its interpretation. A description of this journey is needed for validity: indeed, sharing our journey is as important as arriving at our destination. In this chapter, we therefore chart it as fully and as critically as possible.

We believe the key to maintaining validity in a qualitative research project such as ours is to adopt a reflective approach throughout. We share the view iterated by many scholars, but which Alvesson and Sköldberg (2009) aptly describe and summarise, that interpretation, and the interpretation of interpretation, is the key feature of research. They state that reflective research considers four elements, which we highlight here and discuss further in the following sub-chapters.

- Researchers should be conscious of the interpretation made. We have channelled the interpretations from the outset with the help of the CADEP analytical framework. Despite this shared analytical starting point, 
the following chapters use additional theoretical notions to facilitate interpretation. The framework is discussed in detail in the next section.

- Researchers should be prudent with the systematics of the research procedure. Arguably, the systematics of the research procedure is the aspect of a research report which usually receives the most attention. We have devoted considerable time to developing systematic approaches and common goals in gathering data and indexing the research material. This work is described in detail in the section discussing the technical aspects of our research design, as well as in the appendices.

- Researchers should be aware of the political and ideological role of social science research.

- Researchers should be reflective concerning representation and authority in their work. These two elements of reflective research, the political and the ideological, and the way the text seeks to claim authority (Alvesson \& Sköldberg 2009: p. 273) are intertwined in this book. This intertwining resembles the reflection offered by post-colonial theories and relates to us as researchers as cultural in- and outsiders and to the questions of how we can build an understanding of Brazil, China, and Russia with "Western" concepts from the Global North (see Centeno, Kauko \& Candido 2017). We construct this reflection by analysing a set of research narratives from the members of our group in the penultimate section. The political implications are already clear in our research aims as we analyse the use of political space; this is a question that we address in the final chapter.

Our research design is best described as abductive, where theoretical and empirical work are complementary, concentrating on "pattern finding [which] is at the heart of science" (Alvesson \& Sköldberg 2009: p. 7). In gathering our research material, the CADEP framework focused our attention on actor relations and room for action, but our analysis was conducted more inductively, resulting in an investigation of the problematics which cut across the three cases and their inherent contextual logic. This links well to the reflective process of research, and the starting points of abduction reflect the fact that the same data open a maze of forking interpretative paths (Hanson 1972; see Alvesson \& Sköldberg 2009: pp. 7-8). To put this differently: our research design increases the need for the scrutiny of validity. The four elements of reflection Alvesson and Sköldberg describe, listed here, provide us with tools to understand how deductive elements with their cultural presuppositions and theoretical underpinnings or inductive analytical interpretation with its technical solutions have all affected our work. These aspects are elaborated in the following.

\section{Interpretation: comparing three dimensions of dynamics}

We continue this reflection on the nature of our research by addressing the question of our analytical framework in relation to those of others. Our research concentrates on understanding the political dynamics in QAE. To 
posit the relevance of focusing on dynamics instead of processes of dissemination, adaptation, and implementation, in this section, we relate our view more closely to comparative education theory and methodology. We call our method "comparing dynamics" to indicate our understanding of our research's analytical unit, the dynamics of education politics, implying our interest in the movement involved in education politics.

The adoption of the dynamics of the QAE agenda as our unit of analysis indicates our concern to study global and local practices and policies in relation to each other and our presupposition that they are mutually contingent (Schwinn 2012) and often interrelated (Schriewer 2009). While our study is undertaken within the borders of Brazil, China, and Russia, our approach is situated within the growing research corpus which problematises the traditional understandings of country-bound territorialism and the dichotomy of an abstract global and concrete local and which is moving towards an understanding of the production and use of space (Anderson-Levitt 2012; Dale \& Robertson 2002; Robertson, Bonal, \& Dale 2002; Werner \& Zimmermann 2006; Carney 2009; Vavrus \& Bartlett 2006).

By focusing on dynamics, we aim to transcend both conceptual global-local dichotomy and methodological nationalism while observing the golden rule of explanatory comparative studies, which is that context matters. Our comparing dynamics perspective engages with what Steiner-Khamsi (2014) calls a "contextual comparison", which we see as an invitation to understand the multi-layered comparative context. Multi-layeredness relates to how our analysis considers actors from, and the developments occurring in, different contexts of action, ranging from schools to international organisations.

Studies engaged in cross-national comparisons have either shown that political or geographical boundaries are poor variables for explaining educational phenomena or asserted that local particularities are behind variations. The challenge today appears to be to operationalise a research design that captures the complexity of cultural socio-political contexts which are sufficiently inclusive to structure, and be structured by, other contexts but remain sufficiently exclusive to (re-)engender contextual differences. As Chapter 1 indicates, we use the word transnational to capture the multi-layered nature of context, the practices and policies which develop amidst this setting, and the dynamics and spaces of action they produce.

We develop a contextual comparison which considers vertical and horizontal analyses. We combine a horizontal comparison of the problematics which cut across the three cases with a vertical analysis of the different contexts within each case. It is important to note that our understanding of "contextual comparison" (Steiner-Khamsi 2014) includes agency. This means conceptualising agency and relationality as simultaneously embedded in contextual cultural and socio-political situations and in self-directed actions which, although subject to changing power structures, enable actors' construction of possibilities and room for action as indicated in Chapter 1. In understanding dynamics, we aim to arrive at a description of the relations of actors in these cases which will allow 
us to understand the patterns, limits, and possibilities of action across Brazil, China, and Russia.

In Chapter 1, we described three analytical dimensions for comparing dynamics: the political situation, political possibilities, and the use of political space. In Table 2.1, we summarise how the CADEP framework steers our work and how it links to the questions of QAE dimension by dimension. Here, we must note that the different dimensions of analysis overlap in the different chapters, meaning that all chapters chart all dimensions to some extent.

\section{The political situation: a constellation of actors in a socio-historical context}

As Table 2.1 indicates, in analysing the political situation, we focus on how socio-historical dependencies create the basis for actor relations and how these relations are reshaped by QAE policies. The results of the Fabricating Quality in Education study raised questions about changes in actors in a political situation, which revealed the interconnectedness of the buttressing and creation of new organisations working on statistics in Europe (Lawn \& Segerholm 2011). The national reactions to external signals may vary (Grek \& Rinne 2011) and depend on path dependencies (Kauko \& Varjo 2008). However, it is clear the ascendancy of new actors is essential in reforming actor relations (e.g., Barber 2014).

The question of the political situation culminates with the idea of an opportune moment (kairos) when policies can be changed (Palonen 2006). The dimension of the political situation leads us to analyse what the political structure, with its constellation of actors, allows in its socio-historical and transnational context (see Simola et al. 2017). While the constellation of actors and its

Table 2.1 CADEP framework for analysing QAE in this book

\begin{tabular}{llc}
\hline Dimension & Questions & Relation to QAE \\
\hline $\begin{array}{l}\text { (1) The political } \\
\text { situation }\end{array}$ & $\begin{array}{c}\text { What is opportune in a } \\
\text { specific socio-historical } \\
\text { and transnational } \\
\text { situation? }\end{array}$ & $\begin{array}{c}\text { Analysing the actor constellations } \\
\text { and their formation in the } \\
\text { socio-historical situation and } \\
\text { the quality-related transnational } \\
\text { education networks. }\end{array}$ \\
$\begin{array}{ll}\text { (2) The political } \\
\text { possibilities }\end{array}$ & $\begin{array}{l}\text { What are the political } \\
\text { possibilities opened by } \\
\text { prevailing discourses? }\end{array}$ & $\begin{array}{c}\text { Analysing the central debates } \\
\text { and problematisations: how are } \\
\text { quality discourses formed, and } \\
\text { how are they related to what is } \\
\text { considered possible in education? }\end{array}$ \\
$\begin{array}{ll}\text { The use of } \\
\text { political space }\end{array}$ & $\begin{array}{c}\text { How do the relevant } \\
\text { actors exploit the }\end{array}$ & $\begin{array}{c}\text { Analysing action in the space where } \\
\text { QAE policies are used to reshape }\end{array}$ \\
& existing situations and & the practices, discourses, and \\
& possibilities? & positions of different actors. \\
\hline
\end{tabular}


relationship to the socio-historical situation has been studied with the help of policy process theories, the transnational dimension is an addition the developments in comparative theories can offer.

Indeed, the political situation dimension has been studied in political science literature in the context of national policy processes. Kingdon (2003) emphasises the role of policy entrepreneurs in waiting for the right moment to introduce a solution to emerging problems. Baumgartner and Jones (2009) find that policy changes in bursts after an agenda has been populated with similar ideas. Sabatier (1993) emphasises the role of external factors in sub-system changes. All use a different interpretative framework for changes in the political situation but agree that socio-historical factors are important to understand the external limitations for politics as it evolves. They also regard the political constellations of actors as key to an understanding of the internal logics of a political system. We therefore see the relationship of these internal and external factors as one of the main elements in understanding a political situation (Kauko 2013; Simola et al. 2017).

Theories concerning the policy process have focused on national decisionmaking, but they cannot escape comparative research's criticism of methodological nationalism. Whether defined by territoriality or political scope, seeing scales or levels of action like the national as analytical units is questionable and needs reconsideration (see e.g., Collinge 2005 and Issue 3 of Comparative Education 49, 2013). We do not deny their assistance as widely used heuristic devices in elaborating and understanding arguments, and we therefore do not entirely avoid them. However, we subscribe to the idea of the mutual embeddedness of the local and the global, or the sub-national, national, and international, creating transnational room for action.

A political situation is interwoven at both levels and scales, as well as history (see Nóvoa and Yariv-Mashal 2003). Studies in global history (e.g., Ressler 2010) and the sociology of globalisation (e.g., Sassen 2007) show the entanglement of levels and scales in the (re)construction of historical and social processes. They are not only connected through the mutual influence of persons or ideas; they also permeate each other: practices and policies pertaining to the global occur at the local level (Sassen 2006), and micro-activities cutting across localities have a global reach (Santos 2006). Space and scope, reach and impact are no longer defined by the scale of each occurring action. This perspective is useful in studying the effects of the global agenda on QAE (Chapter 1).

\section{The political possibilities: understanding politicisation}

The second dimension of our analysis, political possibilities, links to how the discourses shape what the actors see as possible. It is generally concerned with identifying the possibilities in the existing discursive formations and what is politicised. This dimension might be described as an analysis of the discursive conditions and resources (Simola et al. 2017). When actors attempt to create more room for their action, they may try to politicise various issues 
(Palonen 1993, 2003). For example, this entails the aim of placing new issues on the political agenda, disputing or compromising on an existing issue, or, in the broadest sense, the expansion of the political arena by the introduction of new players or of old players as newly relevant for the arena. If an issue is not politicised, the action which is seen as possible is limited to the old arena and its patterns.

Another, and from the comparative perspective rather fruitful, view of the question of political possibilities is represented by the question of problematisation. In researching Portuguese-speaking countries, Nóvoa et al. (2003) introduced the idea of "interpretative community". An imagined community was created through a shared understanding of the world. Later, Nóvoa and YarivMashal claimed that the understanding of problematisations and their historical formation was more important than essentialist comparisons of "facts" or "realities" (Nóvoa and Yariv-Mashal 2003). We find this idea useful for our analytical framework. Problematisation is a discursive structure which delimits what is considered relevant, and defines what is "real" and what is expected of different actors (see Bacchi 2012). In other words, this analytical lens focuses on presuppositions about causes linked to proposed solutions and on the wider political concerns embedded in and reflecting broad policy debates and political constraints (Bacchi 2012; see Kingdon 2003).

As we argued in Chapter 1, quality has emerged as a central element of the shared language about education. This has happened both to problematise education and to resolve diverse problems (e.g., Ozga et al. 2011; Kauko et al. 2016). This shared language about education contains a set of uniform solutions to diverse problems and contexts, and these uniform solutions rely on and necessitate a shared approach to problematising education. This shared problematisation plays a significant role in making proposed solutions seem natural and inevitable. However, in questions of QAE, the possibilities for politicisation are also always present.

\section{The use of political space}

The third dimension of our analysis, the use of political space, is the most difficult to analyse. This dimension seeks to describe the extent to which actors can capitalise on an existing political situation and political possibilities. In other words, the political space (with its apt German description Spielraum, "play/game room/space") is shaped by the two other dimensions, and the third dimension seeks to understand how it is used. The use of political space may also be described by other metaphors, such as "the art of playing with contingency" (Simola et al. 2017: p. 18).

Political science literature offers differing views on the use of political space. Prominent here is Kingdon's idea of multiple streams. Drawing on the garbage can model (Cohen, March, \& Olsen 1972), he describes how political actors aim to combine policies and problems at the right moment and introduces the idea that actors (for Kingdon, policy entrepreneurs) prefer certain 
solutions and try to find the right problems to couple these with, rather than vice versa (Kingdon 2003). The model has been criticised for its heuristic view and for its lack of understanding of historical trajectories (Zahariadis 1999; Baugartner, Green-Pedersen, \& Jones 2006: p. 963). However, it helps us to understand the resourcefulness and complexity of political action - how the first two dimensions of political dynamics (the political situation and the political possibilities) create the frame for political action as they determine actors' room for action.

Here a relevant contribution arises from the understanding of the social construction of space, which has been an element of comparative education since at least the 2000s. Larsen and Beech (2014) describe a "spatial turn" which focuses our attention on the relational notion and productive functions of space. This view holds that a "relational notion of space implies understanding that space not only exists in substantial, concrete, and separate forms, but as sets of relations between individuals and groups" (Larsen and Beech 2014: p. 199), and that the "global is not just some space, out there, without material basis. It is produced in local settings" (Larsen and Beech 2014: p. 200). We agree with this, and we believe the use of political space seeks to understand this productive function through an understanding of action or of how the space for action is produced through the interpretations and alterations made in the political situation and political possibilities. Another important contribution to the development of our understanding of the uses of space in comparative settings is what Carney (2009) describes as the "policyscape", by which he means the similar vistas for action created by neoliberal policies in very different contexts.

The focus on political action which we aim to understand in the third dimension of the use of political space has been especially pointed to in comparative education research as a criticism of faceless explanations of processes such as globalisation. Dale and Robertson (2002: p. 12) remind us that the globalisation process always has an actor:"local structures and institutions, processes and practices, are crucial to, even the medium necessary for, the spread of global practices". The same is true of culture according to Anderson-Levitt, because it "is locally produced by particular people who interact in particular places" (Anderson-Levitt 2012: p. 446). Ozga and Jones (2006) point out that travelling policies adapt to embedded ones. Space thus exists as "sets of relations between individuals and groups" (Larsen \& Beech 2014: p. 200). In our analysis, the key question regarding the third dimension of dynamics concerns how the room for action is created as a process which is tied to the relations between actors as well as institutional structures.

In our understanding, research into QAE in education has failed to take room for action as an empirical starting point. An exception is found in DahlerLarsen's theoretical ideas. He sees constitutive effects as the best description of the repercussions QAE policies have: they affect actor relations. For example, this is not captured by the term "unintended effects", which connotes the possibility of controlling the QAE process and dividing it into intended and unintended consequences (Dahler-Larsen 2011,2012). What we seek to understand 
is how in each of our three cases QAE policies are formed through a unique combination of transnational discourses, techniques, practices, and specific political ambitions to distinguish the particular constitutive effects of QAE implementation and, in this sense, how they present comparable and related patterns of dynamics which shed light on the room for political action between different scales.

\section{Systematics of the research procedure}

To analyse the three dimensions just described, we collected a range of research material from different actors in the case countries. The project's research material consisted of documentary material, interviews, and observations. The documentary material used in each chapter is mentioned in the reference list. The interviews are anonymised, and they are referred to with a combination of country codes (BR, CN, RU), actor level and role, and interviewee number (see Appendix 1). Observations are referred to generally and based on observation diaries. Data collection is tightly linked to the local conditions in each context, which we describe briefly.

We selected sub-national and local cases in Brazil and Russia on the basis of their activity in the introduction of QAE policies and participation in international QAE initiatives. In Brazil, we conducted research in Santa Catarina state and its capital, Florianópolis, and in Russia, we studied QAE in the Republic of Chuvashia and its capital, Cheboksary. In China, our access to sub-national and local institutions was restricted, so data collection on these levels followed a different pattern, and the names of the case localities and organisations cannot be disclosed. Details about local cases in the three countries are provided in Chapter 7.

Table 2.2 displays the core structure, themes, and goals of the interview guideline, which was used throughout the project on all levels and in all countries. As well as directing the interviews, it served as a means of focusing other research material collection and therefore also demonstrates the means by which the CADEP frame was operationalised. The political situation was investigated by identifying actors' roles to understand the formation of polity. The aim was to reach an understanding of how the different actor constellations varied depending on the subject and related to the question of the political situation. The political possibilities were largely investigated based on the various themes arising from the interviews' introductory section. This helped us to understand the key questions' problematisations. A range of questions from different parts of the interview guideline, especially those related to change dynamics and the future, was useful in analysing the political room for action.

The complete interview guideline (see Appendix 2) contained many specific and common questions to enable its adaptation to the different situations in each country. The content was also tailored to the respondent's level of action, context, and areas of expertise: we adjusted the interview script to the respondent's profile and history. For example, where the Brazilian national 
Table 2.2 Main themes and goals in the collection and analysis of data

\begin{tabular}{ll}
\hline Theme & Common goals \\
\hline Introduction & $\begin{array}{c}\text { To understand the respondent's view on quality and evaluation in school } \\
\text { education } \\
\text { To understand the interviewee's concrete involvement in - and its } \\
\text { perceived impact on - QAE policy and practice } \\
\text { To understand who the main actors (collective or individual) in the } \\
\text { field are and their role/action and perceived impact on quality and } \\
\text { evaluation policies and practices } \\
\text { To understand the position in the field of the interviewed actor and the } \\
\text { Actors } \\
\text { connections/relations between different actors } \\
\text { To understand changes in actor relations } \\
\text { To understand the role quality and evaluation practices and policies have } \\
\text { played in changes in actor relations and to identify whether and how } \\
\text { they define actor relations (or vice versa) } \\
\text { To understand transnational connections and their impact on national } \\
\text { and sub-national policies and practices } \\
\text { To understand actors' perceptions of expectations and possibilities }\end{array}$ \\
Future &
\end{tabular}

agency responsible for making large-scale assessments, the National Institute for Educational Studies and Research (INEP), was concerned, we adhered to the main frame when interviewing the president and departmental directors, but interviews with technicians were tailored according to their field of work. Likewise, in interviewing those working with the OECD and Programme for International Student Assessment (PISA), we focused on issues such as the relations between Brazil and the OECD or the production of PISA data. Similarly, in Russia, there was a telecommunications agency working in camera surveillance and a media outlet creating school rankings, and in these cases, the interview framework was adjusted according to the area of respondents' work. In the Chinese case, there was a similar logic. For example, the questions to policymakers focused more on the policymaking process, but when we interviewed the technicians from the national assessment centre, questions were more focused on their practical work in developing measurements.

Methodological literature on interviewing those with power emphasises good preparation and strategies to gain access. However, as Walford (2012) states, the real difference here may lie in access. For example, interviews should be well prepared by researching both the context and what the interviewee has already publicly established. Although this is often seen as a feature of interviewing the powerful, they are as important for interviewing others, such as experts and leading managers. Contextual knowledge is also crucial for school interviews, for example. This was embedded in our research design: interviews were prepared with the help of review literature and document analysis. Furthermore, as a foreign project in three countries, our access question was not limited to interviewing those with power, as the next sub-chapter elaborates. 


\section{Data collection in three contexts}

The Brazilian education arena is wide in both horizontal and vertical relationships. It encompasses the public and private sectors, along with third sector organisations, actors from different levels, and representatives of a variety of institutions, such as government, unions, universities, professional and institutional associations, foundations, civic movements, committees, councils, and schools. As was noted in our literature review and historical analysis, there is also a tradition of government interaction with international actors in the history of Brazilian education (see Kauko et al.2016). We spent three periods in Brazil: March to July 2015, October 2015 to January 2016, and September to October 2016. The research data include documents, interviews, and observations.

The Brazilian documents we analysed ranged from reports, decrees, laws, regulations, plans, and official discussion papers about education and QAE in Brazil to websites, online newsletters, Internet news, and videos by international organisations (e.g., the Organization of American States (OAS), the Inter-American Development Bank (IDB), the OECD, the United Nations Educational, Scientific and Cultural Organisation (UNESCO), the United Nations Children's Fund (UNICEF), and the World Bank), other international actors (e.g., the Pearson Foundation, the Inter-American Dialogue Network, and BRICS), the federal government, national agencies, the Santa Catarina government, the Florianópolis government, third sector institutions, civil society movements, and private organisations. For each of the three selected public schools (see Chapter 7) we also analysed school documents (e.g., the Pedagogical and Political Plan) and data concerning these schools made available by INEP and private organisations (e.g., QEdu), along with websites, news, videos, photos, social media, and other materials provided by schools.

Similarly, the number of interviews reflected the breadth of the Brazilian education field and its ease of access (see Appendix 1). All interviews followed a semi-structured approach based on the interview guidelines. Interviewees formally consented to the interviews, which were recorded and later transcribed. School interviewees were selected within each school community for their different roles in respect to QAE policies and practices, and we attempted to cover all involved actors (administrative staff, teachers, students, and parents). We undertook eight weeks of observations in schools, carried out in three periods: 1) before interviews in schools, to familiarise ourselves with their environment, actors, interactions, and daily routine; 2) when interviews were conducted, to pay special attention to the national test examination, classes, and school staff meetings; and 3) having completed interviews, to follow the routine and identify the effects (if any) of the national test examination on the school environment. We observed classes, teachers' meetings, school council meetings, teacher training, external examinations, elections of school principals, end-of-schoolyear meetings, and daily activities. Additional visits were made to schools before the beginning of the fieldwork period and after its completion. 
In Brazil, we were also able to make observations at meetings and events organised by sub-national and local governmental offices and third sector and civil society institutions. We observed two weeks of the State Council of Education of Santa Catarina's work, which included special committee meetings, the meetings of the presidents of special committees, plenary sessions, and the daily routine; one working day of the Municipal Council of Education of Florianópolis, including the monthly meeting of municipal councillors; one working day of the City Council of Florianópolis, including the Education Committee meeting; two working days of the Movement Santa Catarina for Education, which included the Fourth International Seminar of Education organised by the Confederation of Industries in Santa Catarina (FIESC) and FIESC's plenary session; and one monthly meeting of a neighbourhood civil society association. Informal interviews were conducted with relevant actors (some of whom were also formally interviewed). These informal interviews were neither audio-recorded nor coded but were considered as observation notes.

In China, as Chapter 3 explains in more detail, despite increasing decentralisation, the educational system remains highly centralised. The Ministry of Education takes the leading role in organising and governing education development. The QAE functions of the Ministry of Education are performed by two sub-systems, the supervision system and the national assessment system. NGOs play a limited role and are required to coordinate their activities with the state's requirements. At the same time, policymaking in China actively involves experts, especially from academia. Because of these specific features of the QAE system, the fieldwork in China included interviews with both government actors and experts at the national, sub-national, and local levels.

The initial research design included a larger number of interviews in China. However, despite official claims that the country is opening to the world, the attitude to foreign queries remains cautious and reserved. We were not permitted to speak to policymakers in the higher echelons of the Ministry of Education, so we had to compensate for this by focusing on more accessible actors and information from open sources, such as official documents and media publications.

We conducted the first period of data collection in China in June and July 2015, when we undertook interviews, workshops with local inspectors and politicians, and four school visits in a selected city. We also interviewed sub-national actors from NAEQ (National Assessment of Education Quality), the local bureau of education, and the supervision office. In the second period of data collection, in March 2016, we conducted interviews at the Ministry of Education, NGOs, IGOs, and with more researchers working as consultants and experts in the supervision system. We also conducted two further interviews with principals.

We collected Chinese national documents related to QAE and the main education policies issued by the Ministry of Education, the central government, and the national supervision office. The Chinese government's five-year 
strategic plans guide the direction of educational development. We analysed national plans from 1980 to 2010 and the ten-year plan for the period from 2010 to 2020, which aims to transform schools' examination and evaluation culture. We also analysed the Law of Compulsory Education (1986, 2006, and 2015), the annual work plans of the Ministry of Education from 2007 to 2016, Supervision Decrees (1991 and 2012), and National Supervision Reports from 2005 to 2015. Apart from these documents, we analysed the websites of the Ministry of Education, NAEQ and sub-national level bureaus of education, and the public speeches of national leaders and the minister. We collected bulletins (in total 54 issues to the end of 2015) from NAEQ's website, in which the latest assessment results are published with information about assessment events, training, and collaboration with foreign organisations and researchers. We also analysed reports from international organisations (the OECD, UNESCO, UNICEF, and the World Bank, a total of eight reports dealing with China and QAE), and Chinese NGOs working on QAE issues, as well as these organisations' websites. At the local level, we analysed the websites of education bureaus, archived documents, and local implementation plans for national policies. School websites were the main source for school document collection.

Given the restricted access, QAE-related seminars and school visits became an important additional means of collecting interview and observation data in China. The team organised a conference to publicly discuss Chinese QAE with key actors, such as inspectors and decision-makers from local supervision offices. Attendees represented a wide range of actors from the national to local level and included core planners and local policymakers. Information from lectures and discussions was recorded and collected as part of the data. School visits facilitated data collection at the school level. Visits typically started with a workshop on school QAE practices for principals and teachers. The schools' presentations were followed by a discussion about the project's interview guide, with the emphasis on "actors", "changes", "challenges", and the "future". Some visits were joined by local researchers cooperating with the schools. Visits also included school tours accompanied by teachers or principals. Some schools prepared programmes performed by students and visits to classrooms and laboratories.

In the Chinese research environment, special attention was paid to the gradual building of trust in local communities, as there were doubts about the intentions of our research and our interest in their localities, and expectations of a formal government letter of introduction justifying our undertaking of research in China. However, we met challenges in obtaining this from the Chinese central government (see the next section on our research journey). To secure communities' trust, we clarified that data collection was intended only for academic research, emphasised our strict commitment to research ethics, and promised to maintain the anonymity of interviews.

The national QAE arena in Russia comprises a range of government agencies and research institutions subject to or contracted by two key state actors: the Ministry of Education and Science and its subordinate organisation 
Rosobrnadzor (the Federal Service for Supervision in Education and Science). The career paths of many QAE experts include academic and government positions at the national or sub-national level and sometimes involvement with international organisations. It is therefore difficult to draw clear distinctions between the roles of interviewed individuals and the levels at which they work. Other actors, including media, publishing houses, teacher associations, and private companies, perform more specific functions within the QAE system, such as developing rankings, evaluating national test materials, or organising training for schoolteachers. International organisations' presence in Russia is currently limited (for more on actors, see Chapter 4).

National-level interview data in Russia were collected in two periods, in June and October 2015. Data at the sub-national and local levels were collected in four periods in a total of eleven weeks. A one-week piloting visit to Cheboksary in November 2014 included interviews and two school visits and was followed by three periods of participant observation in schools and local-level interviews in May and June, October and November, and December 2015.

Documents analysed at the national level included government programmes, reports, decrees, curricula, newspaper articles and news items, presentations and speeches by relevant individual actors, video seminars, and government agency press conferences. We also followed discussions at Russian academic seminars, in person and online. The development of the QAE system in Russia was also traced through a review of academic journals and books in Russian from 1990 to 2014 (see Gurova, Piattoeva, \& Takala 2015). These forums included academic publications and expert discussions and essays by researchers, teachers, and members of parliament. At the sub-national level, we analysed documents issued by the Ministry of Education of the Republic of Chuvashia and its Center for New Educational Technologies, including laws, regulations, guidelines, plans, and public reports. Locally, we analysed programmes, work plans, information circulars, the public reports of the Department of Education of Cheboksary and the city's Center for Monitoring and Development of Education, and school regulation and action plans. We also analysed the websites of local organisations and schools.

The significant influence of national academic experts on QAE system development, as well as their interest in our study, explains the large number of interviews with experts in Russia. However, we experienced difficulties in accessing Rosobrnadzor and its subordinate institutions, so their work was largely covered by document analysis and review of websites and media sources. Locally, schools proved the most accessible and cooperative actors, while most officials of municipal institutions were reluctant to participate in the study. Data about municipal organisations were therefore gathered either by document analysis or interviews arranged with the help of schools; school administrators also shared their perspectives on the work of the supervising authorities. Semi-structured interviews at all levels were based on the common interview script (see Appendix 3), which was modified and developed according to each interviewee's expertise. At the school level, we also conducted several unstructured informal 
interviews to complement our participant observation. Formal interviews were audio-recorded and transcribed, and written notes were taken during informal interviews and observation.

Participant observation periods were selected with the intention of including all the main evaluation procedures in schools. Procedures were identified from policy documents about QAE and from schools' work plans: state examinations after grades 9 and 11, subject Olympiads and contests, and internal school examinations and assessments (e.g., end-of-quarter or end-of-year tests). Two public schools in Cheboksary were observed, with observations of classes, meetings, internal examinations, and everyday activities. Interviews were conducted in these and three other schools. We also observed three municipal seminars for teachers. When a preliminary analysis of the collected data had been made, we organised a follow-up seminar for the two observed schools, at which our preliminary research results were presented and discussed.

\section{Qualitative content analysis of interviews and documents}

Qualitative Content Analysis (Mayring 2000; Hsieh \& Shannon 2005; Schreier 2012) is instrumental in systematising extensive data. Our coding frame allowed us to index and arrange research material in manageable pieces and helped to build the different foci of the research questions, such as identifying all actors and the descriptions of their relations. However, most of the codes were developed in an iterative process and based on the research data. The project's organisation meant that emphases differed slightly in the different countries. Analysis of documentary data and interviews differed, for example, when interview data were thoroughly coded and documentary data were not.

In the Brazilian case, documentary analysis was made throughout the research process, taking into consideration the project framework, the preparation of interviews, and the subsequent concept-driven and data-driven coding of interviews. The documents were thus analysed by the thematic issues relevant to the analyses over the research process. Thematic analysis was undertaken to systematise the data. It also served as background information which contributed to the tailoring of interview questions and literature reviews. The Chinese team also undertook a discourse analysis to analyse Chinese political problematisation in school education. In the Russian case, a thematic analysis of documents was undertaken. National and regional regulations, guidelines, and reports, as well as Russian academic journals and books, were analysed before conducting interviews to inform the latter. Other types of documents were analysed throughout the research process.

Interviews were exhaustively analysed. The intention was to reduce the material under scrutiny systematically and flexibly. We thus used a mixture of deductive and inductive logics, i.e., the coding was both concept and datadriven. The starting point of the coding process was the main four themes guiding the interviews, which in turn were oriented by the research questions. This framed our coding view - what we were looking for - and frequently the 
definition of the main categories. The coding proceeded with a data-driven approach, as most of the sub-categories, and even many categories, were then generated according to what the material provided. To give a brief example (see, however, a comprehensive explanation of the coding process in Appendix 2), in the Chinese coding, we include the main category of "actor", which corresponds to one of the four initial themes. The sub-categories "teachers", "experts", and "policymakers", however, emerged from the material. Nevertheless, since we decided to code all "changes" under the same code, changes in actors' positioning or roles were also coded under this category, while under the category "actor", we included for the most part the description of the actors provided by the interviewees. In the three teams, the exhaustive coding of the interview material thus combined deductive and inductive reasoning.

\section{Research journeys - another layer of research data}

The different perspectives on reflectivity in this research project were described in this chapter's introduction. One of the goals generated from these ideas was to be alert to the political and ideological roles of research, as well as the representations and authority produced in the study (Alvesson \& Sköldberg 2009). These goals are demanding in a large research project. It is equally difficult to report them because reflectivity has occurred throughout the various project meetings and writing processes. Another layer of complexity is added by the fact that we research practices which themselves capitalise on scientific discourses, collect data, and claim to construct better policy based on firm scientific evidence.

In this sub-section, we illustrate some of the reflective perspectives by turning the focus on ourselves as researchers collecting research materials and analysing complex phenomena in the cultural and political contexts of our three countries. A starting point is that researchers are not detached external observers of their study but are incorporated in the field in complex and sometimes unpredictable and even incomprehensible ways (see Holstein \& Gubrium 1995; Walford 2012). Researchers then undergo negotiations with others and themselves about ethically sustainable or practically manageable compromises in positions, accesses, and roles.

We observe that reflection on the QAE research process can illuminate the workings of QAE itself. We attempt to produce an interesting additional layer of research data. This supports the assumption that self-reflection on the ambiguities of fieldwork is only relevant if it can move beyond mere revelation (Alvesson \& Sköldberg 2009; Koning \& Ooi 2013) and is "essential to the argument" rather than being "a decorative flourish" (Behar 1996: p. 14). Thus, in this sense, it enables "a fuller and deeper representation of the groups and communities we aim to understand" (Koning \& Ooi 2013: p. 30).

All the researchers engaged in the fieldwork wrote short personal histories of their fieldwork experience, considering fieldwork in the broadest sense of the term - not only as being "in the field" but also as fieldwork preparation, 
corresponding with potential respondents and collaborators, and collecting background material. These very diverse stories, some more elaborate and personal than others, captured memories which expressed the puzzling or satisfactory details of fieldwork, as well as complex feelings and thoughts that broadly responded to the question "What characterised my involvement in the accumulation of data about QAE politics in Brazil, China, or Russia?” In engaging in producing and analysing these texts, we hope to bridge the border between researcher and subject, attempting to document and make sense of some of our own experiences on the journey. Considering the outcomes of our research thus meant addressing "the processes that allowed such research to happen" (Bondy 2012: p. 587). In referring to these stories, we use the country code to indicate the team from which the author of the text comes.

\section{Coping with politics and bureaucracy}

Brazil underwent great political instability during the project. The political turbulence suffered by the government of Dilma Rousseff (January 2011 to May 2016) led to frequent changes in education ministers (six ministers and one interim minister). This instability culminated in her impeachment and Vice-President Michel Temer assuming the presidency. In one case, following a sudden change in the national minister of education, interviews already planned and arranged at lower than ministerial level proved possible, but higher-level civil servants (e.g., departmental secretaries), who changed one after the other during the ensuing months, remained inaccessible:

Once back to work in Florianópolis, keen to regain the lost days, I directly began with follow-up emails and phone calls. But suddenly, something was weird: my contacts in the Ministry of Education were silent; I barely could pass through the receptionists, and when I managed to do so, it was only to get to someone's secretary.

Although the first moments of political uncertainty in Brazil affected the data collection phase, the subsequent ones affected the topicality of our research findings. A year after our fieldwork was conducted, the new Temer Government annulled some education reforms, including the decree on the National Evaluation System of Basic Education (grades 1 to 12). The construction of this system took years of societal effort; its termination took a single day. When it was annulled, we had just submitted a journal article for review which partly addressed the establishment of the new system (Centeno, Kauko, \& Candido 2017) and were left wondering how the gap between fast-paced political development and the usually slow-paced publication process might be bridged.

On the one hand, we conducted our research amidst political instability, and this turmoil affected school work: interviews with teachers and school staff took place during a strike against the government's attempts to remove 
some of the teachers' rights. We also encountered difficulty in receiving ethical clearance for school fieldwork. On the other, our general experience was that most Brazilian actors were easy to approach. Despite the instability at the school level, interviewees were quite open to participating in our research. Whereas the political changes made it difficult to access the politicians and higher civil servants who simultaneously occupied government positions, contact with politicians and civil servants who did not hold such posts during the fieldwork was less complicated. In Brazil, these actors remain connected to the political world by occupying either leadership positions in municipal, state, or federal governmental bodies or expert or administrative positions in tertiary sector organisations. We therefore received largely favourable responses to our interview requests from international organisations, representatives of national NGOs, politicians, and leading civil servants.

The seal of official approval plays an important role in contemporary Chinese society, to the extent that in some instances, it is almost impossible or at best risky to proceed without it. However, the required stamp is often submerged in a sea of red tape. In dealing with government matters, the process is usually very time and energy consuming, especially as there is no official onesize-fits-all protocol concerning how one should proceed in obtaining research authorisation. With all this in mind, our team decided to attempt to receive approval at the national level, as we expected such a document to open doors all the way to the level of individual schools.

We anticipated personal contacts, firm backing of the Finnish national academic research funder - the Academy of Finland - and the ongoing expansion of bilateral cooperation in education between Finland and China to guarantee support from the high level of command. While the Chinese Ministry of Education found it hard to locate the department best fit to authorise our fieldwork, the unexpected change of personnel in the relevant department and the anti-Western(isation) campaign that swept over the education system quickly hampered our efforts. Our permission was denied, meaning that we would not access any ministerial official or civil servant working on educational matters. However, a successful cooperation agreement with a Chinese university secured access to academics and subnational units relevant for our research topic, while the officials remained out of reach.

The Russian military intervention in Ukraine and the subsequent annexation of Crimea, which began in 2014, resulted in Western and Russian sanctions and counter-sanctions. These unanticipated political events unfolded during our interviews in Russia. Military action, the Russian law restricting the actions of "foreign agents", and the subsequent Undesirable Organisations Bill all fed into a general atmosphere of caution and uncertainty regarding how to respond to visit and interview requests from researchers supported by a Western university. 
On our introductory visit to Cheboksary, the state-level officials were, however, open to meetings, often expressing excitement about possible collaboration with a country whose education system was ranked among the best in the world by the PISA study. Some of our official respondents had participated in earlier World Bank projects and remembered international collaboration as professionally rewarding and a personally exciting exchange of experience. However, we were informally reminded that the current political situation meant that not everyone would be willing to be associated with international research because of the possible personal consequences. In this complicated context, the team often discussed the fact that to gain trust, we needed to counteract two preconceptions. The first was that because we came from a country of high education quality, as measured by PISA, we would come to a country performing less well with a judgemental attitude and with the intention of comparing the "successes" of Finland with the "failures" of Russia. We felt our partners positioned us as experts, which made us uncomfortable and which we found unnecessary. Second, we had to prove to the research participants that their openness to our study would not cause them harm either because of the climate of suspicion towards foreign actors or the systems of control embedded in QAE politics and its diverse institutional and personal effects.

In the Russian case, personal contacts at the national Ministry of Education and one of the leading universities in educational research were crucial to accessing some ministerial officials and educational experts in Moscow and provincial administrative and school staff. However, while we were able to interview ministerial civil servants, we failed to secure access to the agency functioning under the jurisdiction of that national ministry, which controls several sub-agencies responsible for the implementation of national examinations and other QAE procedures. Expecting Russia to function hierarchically, we secured a reference from a very high ministerial official, thinking it would open doors at the lower command level. While the HR department of the agency was quick to answer emails and phone calls, we were told that personal interviews with staff were not allowed, while written responses could be collected from relevant respondents identified by the agency itself. We were told that these responses would then be reviewed by the head of the agency and sent to us in summarised form.

At this point, the Russian team faced an ethical dilemma: Should we give in to this proposal, which would provide us with relative access while risking our reputation as an independent research team and allowing the agency to use our research to engage in what we saw as direct control of its own personnel? The situation echoed what Koning and Ooi (2013: p. 29) describe as transferring research "into another agenda", which we were unhappy with. Following a lengthy team discussion, we decided not to engage in this process, shifting our main focus to the local level, documentary and media analysis, and interviews with academic experts and, among others, retired officials, politicians, and civil servants who no longer held politically sensitive posts. While we still fail to completely understand the reaction of an agency which presents 
transparency and accountability as its main functioning logic, we see it as a manifestation of the closeness of the "centres of calculation" to public view, as well as a signal of the volatility of the actors who themselves sat amidst vast hierarchies and were constantly worried about job security (see Kipnis 2008). The head of the agency who denied us access had succeeded another young functionary who held his post for only a year and was dismissed for allegedly failing to combat high levels of cheating in examinations. Our project started when the current leader had held his post for a year and was perhaps mindful of his predecessor's fate (see Piattoeva 2016; Piattoeva 2017). This and other situations alerted us to the importance of paying attention to the agendas and interests of active or passive research participants in relation to fieldworkers and the overall research topic.

Although all three countries appear quite dissimilar in their openness to academic research by foreign scholars, we found our aim of interviewing actors who were part of official government structures and securing research authorisation was very uncertain and depended on situational or external elements, no matter what official procedures were in place. Cultural proficiency, knowledge of the political context, and constant readiness to alter plans and seize sudden opportunities were indispensable in securing successful fieldwork. At the same time, we interpreted silence or failed access as a form of engagement which revealed something about the system we were studying, providing important data and findings concerning the problems of access which reflected the broader social milieu (see Bondy 2012).

The bureaucratic pressure faced by the three teams during the initial stage of making contacts, securing the necessary research permits, and accessing relevant respondents was an important experience which enabled us to live and feel our way through some of the processes later described to us by the research participants as burdensome demands of various evaluation processes and data collection requests emanating from different stakeholders. Emotionally, we were able to relate better to the feelings of frustration, scepticism, or amusement such processes inflicted. Some of us experienced the bureaucratic processes as tricky but surprisingly seductive in their nature and in their effects on subjectivity.

\section{Manifestations of hierarchies and effects of $\mathrm{Q} A E$}

The schools to which we were invited on our introductory visit to the city of Cheboksary and which later became the prime observation and interview sites for our fieldwork were motivated to engage in our study by the opportunity to strengthen their local image and exploit cooperation with foreign researchers to gain credibility with the municipal authorities. Local reactions to foreign cooperation were thus far from univocal, despite the geopolitical upheaval. During our school visits, we sometimes felt that a show was being put on for us and that school principals were deliberately promoting a good image (as they saw it). This experience was shared by the teams visiting schools in both Russia 
and China. As we later discovered, emphasis on positive image and reputation are essential to understand the impact of QAE and the reaction of schools and teachers to it, meaning that it would be too narrow to interpret these local reactions without consideration of the strategies for coping with QAE. Put simply, school staff initially interpreted external visits within the framework of quality evaluation and reacted to our interest accordingly.

One of our team members reported after her first day in the field in Russia in the following words, alerting us, among other things, to an intriguing parallel between our research and large-scale international assessments:

On Friday I met with the school principal and her deputy, who will be my contact person for this stay. The principal stressed that they need some official document - from the local Ministry or from our University - explicitly stating that their school participates in an international study. As the deputy principal explained later, their participation in international studies counts as the so-called project activity and gives them privileges in regional rankings, and even additional funding. So that is their main motivation to take part in our study. When schools participate in TIMSS [Trends in International Mathematics and Science Study] or PISA they get the same bonus.

Apart from obtaining recognition from the educational authorities, the Russian schools in our study could exploit their involvement in our research project in other ways. One of us made observations at the end of the school year and attended several graduation and end-of-year events. These included performances prepared by students and teachers and speeches from "honoured" guests, e.g., local entrepreneurs, members of the municipal council, and local administrators. The audience included school staff, graduates, and their families and friends:

At the first graduation event that I attended I was invited to sit close to the stage. I prepared to take notes, as I normally did at lessons and meetings, and did not expect any special attention. Suddenly, I heard my name and position ("a researcher from the University of Tampere in Finland") from the stage - I was listed among the honoured guests who were later to greet the graduates with some speeches. It was a complete surprise, and I had to quickly think about what to say. Later during my stay, another event was organised with even greater publicity ... The purpose of the event ["The Stars of the School"] was to congratulate, honour and reward bestperforming school students: those who had high academic achievements, won local learning competitions, led student organisations, etc. A deputy principal called me in advance and asked me to prepare a small speech. On the one hand, my position as an international researcher made me, in school administrators' view, a fit person to address the students. On the other hand, as I felt it, the school demonstrated its prestigious "international 
cooperation" to a wider audience, including parents and local authorities in the audience.

Teachers in Brazil were very enthusiastic and spontaneous when they were interviewed, which we interpreted as their sense that their voices were seldom heard. They appeared to share their thoughts without reservation and often seemed deeply animated by the topic of our research. Their emotional reactions to the questions might be read as shedding light on the very personal, troubling impact of some of the QAE-related policies on schools' daily work and the fulfilment of the duties teachers considered professionally and ethically desirable. Reflecting on individual interviews with teachers in general, some of our team members recalled situations in which teachers began to cry when they expressed their frustration and helplessness in dealing with mounting paperwork, which distracted them from "teachers' work" (Russia), and the unproductive education reforms and teachers' shrinking motivation (Brazil):

She told me she had always welcomed reforms, as she thought they would be the outcome of well thought problem solving, and she would cooperate to implement them. However, at the moment, for the first time, she said she is hopeless. . . "Politicians are not trying to make anything better for anyone [there is a lack of resources and lack of will], but now even teachers are so demotivated that they are not coping with the education mission." She links this demotivation to the vulnerable career of educators, who are badly paid and need to work several shifts to provide minimum income for their families. She told me they are always tired, they are not respected in the society and, recently, neither in the classrooms. She acknowledged that they are held accountable for so many things concerning teaching and learning, but complained that, at the same time, they lack autonomy over their jobs and are blamed for everything that goes wrong at the school.

Although the researchers were caught off-guard by interviewees' emotional distress, they also felt that by asking difficult questions and allowing the respondents to express their anxiety, they were able to give something in return - a momentary emotional relief and a sense that thoughts and feelings mattered: "In the very moment when their supervisors were putting pressure on them, demanding good examination results and completed end-of-year reports, I was there to listen and sympathise" (RU).

In China, in group interview situations, teachers' voices were often silenced or overshadowed by senior staff members answering questions on their behalf. This supported the idea that there was a silent rule that speaking priority followed the hierarchical order: senior staff, senior teachers, and junior teachers. If not addressed directly, most junior teachers waited for senior members 
to answer first. Group meetings' interior dynamics seemed to characterise the hierarchy of the teaching staff.

In one of our group meetings with both senior and junior personnel, new teachers always had to wait for the senior teachers to talk first unless directly nominated to answer the question. We addressed a question to a new teacher, and he/she immediately suggested that a senior teacher should answer it, explaining to us that the senior teacher might know better. This younger colleague only started talking after the senior teacher declined to answer and recommended that this new teacher should answer.

$(\mathrm{CN})$

Our observations suggested formal promotion led to differences in the staff hierarchy. Senior staff members had once been teachers. When they were promoted to the school administrative or management level, they started to behave and were treated as experienced and authoritative teachers, especially by newly recruited teachers. Levels of experience and status were transformed into informal authority. However, there were some variations. For example, in our group interviews, we encountered cases where senior staff answered one question and young teachers challenged the answer with a different perspective.

These authority dynamics changed when the group attendees included staff from supervisory bodies or government. In such situations, inspectors became the authority and retained the right to answer questions first. If there was a difference of opinion, school participants tended to keep silent. For example, there was one case where our research team asked about the challenges of QAE for teachers, and an inspector answered that "good teachers don't have problems, only bad teachers do" (CN-S-05), silencing the whole group and preventing further answers.

\section{Conclusion: the research's room for action}

We started this chapter by emphasising the need for reflection in research and placing our work more systematically within the CADEP framework. Having discussed the practical work of our analysis, we turned the analysis on ourselves and presented an account of our multifaceted research journeys.

We have thus demonstrated that the conduct of this research could not escape each case's basic political dynamics. In other words, we felt the limits of our own room for action in these three contexts. We aimed to learn something from this experience about the phenomena we were studying.

The changes in our contexts' political situation were described by revisiting difficulties in accessing the field and observing that these challenges were entangled in the changing politico-bureaucratic conditions. What we could do and how others perceived us were influenced by the ways in which the study of QAE cut across QAE procedures and their impact. This crystallised the 
ambiguous political and ideological role of social science research in general and research focused on quality politics in particular.

Our room for action in concrete work and research was linked to multifaceted questions of authority. As researchers, we were often concerned about how our research might jeopardise participants' positions. This represented a serious challenge to our work, which we addressed with a consistent anonymity procedure. We could also see power relations at play during our fieldwork, in which some voices were silenced and others amplified. However, we were also able to shed light on the ways participants could find avenues for momentary empowerment through our research. This sometimes happened when our research team's presence was used as a sign of quality or interviewees used our interviews as moments of reflection and inspiration or simply of emotional and professional time off as some heavily burdened teachers did.

As researchers striving for access and recognition, we experienced state authority and bureaucracy which replicated the ways in which QAE systems in each country worked: the chances of gaining access, the strength of the state in controlling the lower levels of bureaucracy, and the way top-down management worked. The research journeys also indicated that QAE as a governance tool left room for action for those it affected. As Chapter 7 demonstrates in more detail, schools have become experienced in playing the game of quality and can use an international research project to their advantage.

In the following chapters, we start to analyse the dynamics in the politics of quality in Brazil, China, and Russia. To assist our reader in navigation, in Figure 2.1, we sketch an approximate map of how intensively the different chapters deal with the various dimensions of our analysis. Chapter 3 describes the relevant aspects of the changing political situations in each country or the historical-social developments which underpin their respective paths to QAE. Chapters 4, 5, and 8, analysing the national level, lean slightly more towards

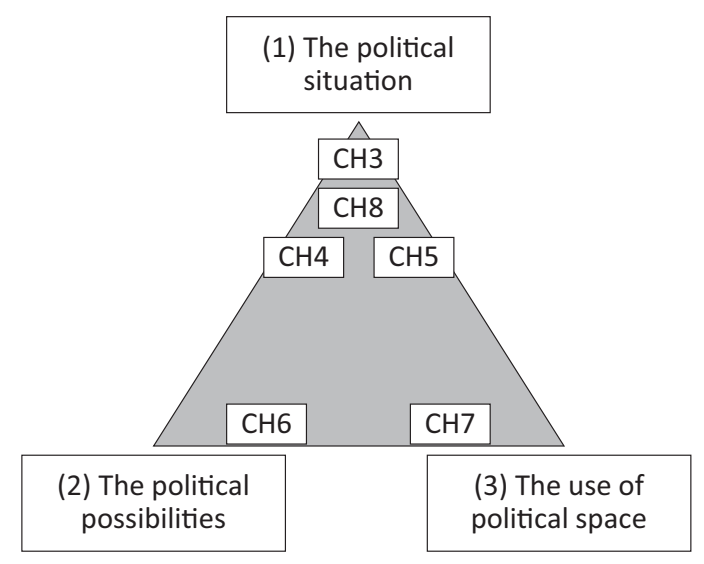

Figure 2.1 Dimensions of the analytical framework (CADEP) and the book's chapters 
analysing the political situation, whereas Chapter 6 leans more towards the political possibilities created in data use, and Chapter 7 scrutinises schools' political space. In Chapter 9, we bring the idea of dynamics to bear on understanding how these analyses of the three dimensions can be drawn together to construct arguments about the dynamics of QAE policies.

\section{Bibliography}

Alvesson, M., \& Sköldberg, K. (2009). Reflexive Methodology: New Vistas for Qualitative Research (2nd ed.). London: Sage.

Anderson-Levitt, K. M. (2012). Complicating the concept of culture. Comparative Education, 48(4), 441-445.

Bacchi, C. (2012). Why study problematizations? Making politics visible. Open Journal of Political Science, 2(1), 1-8.

Barber, M. (2014). Data work. In T. Fenwick, E. Mangez, \& J. Ozga (Eds.), Governing Knowledge: Comparison, Knowledge-Based Technologies and Expertise in the Regulation of Education (pp. 75-85). London: Routledge.

Baugartner, F., Green-Pedersen, C., \& Jones, B. D. (2006). Comparative studies of policy agendas. Journal of European Public Policy, 13(7), 959-974.

Baumgartner, F. R., \& Jones, B. D. (2009). Agendas and Instability in American Politics (2nd ed.). Chicago, IL: Chicago University Press.

Behar, R. (1996). The vulnerable observer: Anthropology that breaks your heart. Boston: Beacon.

Bondy, C. (2012). How did I get here? The social process of accessing field sites. Qualitative Research, 13(5), 578-590.

Carney, S. (2009). Negotiating policy in an age of globalization: Exploring educational "Policyscapes" in Denmark, Nepal, and China. Comparative Education Review, 53(1), 63-68.

Centeno, V. G., Kauko, J., \& Candido, H. H. D. (2017). Quality assurance and evaluation through Brazilian lenses: An exploration into the validity of umbrella concepts. Comparative Education, published online. Retrieved from http://dx.doi.org/10.1080/03050068. 2017.1348084

Cohen, M. D., March, J. G., \& Olsen, J. P. (1972). A garbage can model of organizational choice. Administrative Science Quarterly, 17(1), 1-25.

Collinge, C. (2005, February 23). The différance between society and space: Nested scales and the returns of spatial fetishism. Environment and Planning D: Society and Space, 189-206.

Dahler-Larsen, P. (2011). Afterword. In J. Ozga, P. Dahler-Larsen, C. Segerholm, \& H. Simola (Eds.), Fabricating Quality in Education: Data and Governance in Europe (pp. 150159). London: Routledge.

Dahler-Larsen, P. (2012). Constitutive effects as a social accomplishment: A qualitative study of the political in testing. Educational Inquiry, 3(2), 171-186.

Dale, R., \& Robertson, S. L. (2002). The varying effects of regional organizations as subjects of globalization of education. Comparative Education Review, 46(1), 10-36.

de Santos, B. (2006). Globalizations. Theory, Culture \& Society, 23(2-3), 293-399.

Grek, S., \& Rinne, R. (2011). Fabricating Europe. In J. Ozga, P. Dahler-Larsen, C. Segerholm, \& H. Simola (Eds.), Fabricating Quality in Education: Data and Governance in Europe (pp. 19-31). London: Routledge.

Gurova, G., Piattoeva, N., \& Takala, T. (2015). Quality of education and its evaluation: An analysis of the Russian academic discussion. European Education, 47(4), 346-364. 
Hanson, N. R. (1972). Patterns of Discovery. An Inquiry Into the Conceptual Foundations of Science. Cambridge: Cambridge University Press.

Hedström, P., \& Wittrock, B. (2009). Introduction: Frontiers of sociology. In P. Hedström \& B. Wittrock (Eds.), Frontiers of Sociology (pp. 1-11). Leiden: Koninklijke Brill.

Holstein, J. A., \& Gubrium, J. F. (1995). The Active Interview. Thousand Oaks, CA: Sage.

Hsieh, H-F., \& Shannon, S. E. (2005). Three approaches to qualitative content analysis. Qualitative Health Research, 15(9), 1277-1288. doi:10.1177/1049732305276687

Kauko, J. (2013). Dynamics in higher education politics: A theoretical model. Higher Education, 65(2), 193-206.

Kauko, J., Centeno, V. G., Candido, H., Shiroma, E., \& Klutas, A. (2016). The emergence of quality assessment in Brazilian basic education. European Educational Research Journal, 15(5), 558-579.

Kauko, J., Corvalán, J., Simola, H., \& Carrasco, A. (2015). Historical dynamics in Chilean and Finnish basic education politics. In P. Seppänen, A. Carrasco, M. Kalalahti, R. Rinne, \& H. Simola (Eds.), Contrasting Dynamics in Education Politics of Extremes: School Choice in Chile and Finland (pp. 29-52). Rotterdam: Sense Publishers.

Kauko, J., \& Varjo, J. (2008). Age of indicators: Changes in the Finnish education policy agenda. European Educational Research Journal, 7(2), 219-231.Kingdon, J. W. (2003). Agendas, Alternatives, and Public Policies (2nd ed.). New York, NY: Longman.

Kipnis, A. B. (2008). Audit cultures: Neoliberal governmentality, socialist legacy, or technologies of governing? American Ethnologist, 35(2), 275-289.

Koning, J., \& Ooi, C. (2013). Awkward encounters and ethnography. Qualitative Research in Organizations and Management: An International Journal, 8(1), 16-32.

Larsen, M. A., \& Beech, J. (2014). Spatial theorizing in comparative and international education research. Comparative Education Review, 58(2), 191-214.

Lawn, M., \& Segerholm, C. (2011). Europe through experts and technologies. In J. Ozga, P. Dahler-Larsen, C. Segerholm, \& H. Simola (Eds.), Fabricating Quality in Education: Data and Governance in Europe (pp. 32-46). London: Routledge.

Mayring, P. (2000). Qualitative content analysis. Forum Qualitative Sozialforschung/Forum: Qualitative Social Research, 1(2). Retrieved from www.qualitative-research.net/index.php/ fqs/article/view/1089/2385 doi: 10.17169/fqs-1.2.1089

Nóvoa, A., Carvalho, L. M., Correia, A. C., Madeira, A. I., \& Ó. J. R. (2003). Educational Knowledge and Its Circulation: Historical and Comparative Approaches of Portuguese-Speaking Countries. Lisbon: Educa.

Nóvoa, A., \& Yariv-Mashal, T. (2003). Comparative research in education: A mode of governance or a historical journey? Comparative Education, 39, 423-439.

Ozga, J., Dahler-Larsen, P., Segerholm, C., \& Simola, H. (2011). Introduction. In J. Ozga, P. Dahler-Larsen, C. Segerholm, \& H. Simola (Eds.), Fabricating Quality in Education: Data and Governance in Europe (pp. 1-8). London: Routledge.

Ozga, J., \& Jones, R. (2006). Travelling and embedded policy: The case of knowledge transfer. Journal of Education Policy, 21(1), 1-17.

Palonen, K. (1993). Introduction. In K. Palonen \& T. Parvikko (Eds.), Reading the Political: Exploring the Margins of Politics (pp. 6-16). Helsinki: Finnish Political Science Association.

Palonen, K. (2003). Four times of politics: Policy, polity, politicking, and politicization. Alternatives, $28,171-186$.

Palonen, K. (2006). The Struggle With Time: A Conceptual History of "Politics" as an Activity. Hamburg: Verlag Münster.

Piattoeva, N. (2016). The imperative to protect data and the rise of surveillance cameras in administering national testing in Russia. European Educational Research Journal, 15(1), 82-98. 
Piattoeva, N. (2017). Doing equality through greater transparency? Troubling surveillance expansion in the Russian school system. In S. Carney \& M. Schweisfurth (Eds.), Equity in and Through Education: Changing Contexts, Consequences, and Contestations. Rotterdam: Sense Publishers.

Ressler, P. (2010). Nonprofit-Marketing im Schulbereich: Britische Schulgesellschaften und der Erfolg des Bell-Lancaster-Systems der Unterrichtsorganisation im 19. Jahrhundert. Frankfurt am Main: Peter Lang.

Robertson, S. L., Bonal, X., \& Dale, R. (2002). GATS and the education service industry: The politics of scale and global reterritorialization. Comparative Education Review, 46(4), 472-495.

Sabatier, P. A. (1993). The advocacy coalition framework: Assessment, revisions, and implications for scholars and practitioners. In P. A. Sabatier \& H. C. Jenkins-Smith (Eds.), Policy Change and Learning: An Advocacy Coalition Approach (pp. 211-235). Boulder, CO: Westview Press.

Santos, B. d. S. (2006). Globalizations. Theory, Culture \& Society, 23(2-3), 393-399.

Sassen, S. (2006). Territory, Authority, Rights: From Medieval to Global Assemblages. Princeton, NJ and Oxford: Princeton University Press.

Sassen, S. (2007). Sociology of Globalization. New York, NY: W. W. Norton.

Schreier, M. (2012). Qualitative Content Analysis in Practice. Thousand Oaks, CA: Sage.

Schriewer, J. (2009). Comparative education methodology in transition. Towards a science of complexity? In J. Schriewer (Ed.), Discourse Formation in Comparative Education (3rd ed., pp. 3-52). Frankfurt am Main: Peter Lang.

Schwinn, T. (2012). Globalisation and regional variety: Problems of theorisation. Comparative Education, 48(4), 525-543.

Simola, H., Kauko, J., Varjo, J., Kalalahti, M., \& Sahlström, F. (2017). Dynamics in Education Politics - Understanding and Explaining the Finnish Case. London: Routledge.

Steiner-Khamsi, G. (2014). Comparison and context: The interdisciplinary approach to the comparative study of education. Current Issues in Comparative Education, 16(2).

Vavrus, F., \& Bartlett, L. (2006). Comparative knowing: Making a case for vertical case study. Current Issues in Comparative Education, 8(2), 95-103.

Walford, G. (2012). Researching the powerful in education: A re-assesment of the problems. International Journal of Research \& Method in Education, 35(2), 111-118.

Werner, M., \& Zimmermann, B. (2006). Beyond comparison: "Histoire Croisée" and the challenge of reflexivity. History and Theory, 45(1), 30-50.

Zahariadis, N. (1999). Ambiguity, time, and multiple streams. In P. A. Sabatier (Eds.), Theories of the Policy Process (pp. 73-93). Boulder, CO: Westview Press. 


\title{
3 Historical paths to shared interest in quality assurance and evaluation
}

\author{
Olli Suominen, Vera Gorodski Centeno, \\ Galina Gurova, Johanna Kallo, and Xingguo Zhou
}

\section{Introduction}

This chapter explores and outlines the historical background of understanding the development of quality assurance and evaluation (QAE) policies in Brazil, China, and Russia and thus also prepares the ground for the problematics the subsequent chapters analyse. In doing this, we build largely on the previous research literature, albeit occasionally supplementing our analysis with primary documents, such as media reports, policy documents, and parallels found in our interview material. As the following chapters elucidate, although at the level of practical implementation, the countries' experience differs markedly, at the level of political projects and rhetoric (see Chapter 6), they share a growing interest in QAE. In building the case for future chapters, our foremost task is therefore to ask how these three countries, which until recently developed separately, came to share quite similar domestic expectations and interest in QAE. Drawing on politico-socio-historical approaches, we outline the historical trajectories and antecedents of QAE policies in each national context. Our ambition to trace the socio-historical roots of the phenomenon at hand also resonates with the book's broader framework, as uncovering the political situation is one of the three analytical dimensions of the CADEP framework the preceding chapter introduced.

More concretely, we approach our topic by presenting three case-by-case chronological narratives. As QAE policies are linked to some of the megatrends of the latter half of the twentieth century, which has seen growing possibilities of transnational data flows and an increasing emphasis on economic efficiency in public services, the focus of our analysis will be on post-World War II developments. This historical analysis will extend to the present and the challenges the countries are facing. We summarise this analysis with an integrative summary in which we draw together some similarities and differences in the developmental paths towards the countries' shared interest in QAE. As a postscript, we conclude our work with an examination of signs that the three countries are increasingly engaging with the international community and with each other, especially in matters related to education, suggesting possible future research avenues. 


\section{Path dependency and contingent conjectures}

Chapters 1 and 2 discussed the importance of understanding the path dependencies deriving from our ontological presuppositions concerning complexity and, more closely, how the political situation is analysed as a constellation of actors in a specific socio-historical context. In this chapter, with our focus on processual perspectives in tracing the historical paths leading to the introduction of modern QAE policies, we build theoretically on the notion of path dependency, which essentially asserts that present and future choices are made within the constraints set by past choices (O'Sullivan et al.2006). In the broadest sense, path dependency refers to the very vague notion that "history matters" (Pierson 2000a; Mahoney 2000), but our aim is to go deeper by operationalising the term to show how history matters. Although the concept is used in various ways in different research traditions, all path-dependency perspectives stress several relevant arguments which help us to understand the broader context of developments, such as the interconnectedness of events and the relevance of timing, showing that important developments are frequently the outcome of the earlier breaking points resulting from particular conjunctures (Baumgartner \& Jones 2009; Capano 2009).

All path-dependency perspectives also share an interest in contingent events, which in turn place these ideas within a collective of several theories that together form the complexity theory. This emphasis on contingency further connects our starting point with the book's broader theoretical approach. Different types of path-dependency analysis focus on different types of sequences of events. We subscribe to the notion of reactive sequences, which is a form of analysis especially suited to historical narrative accounts (Mahoney 2000). These reactive sequences are temporally ordered and causally connected and reactive in the sense that events are at least partly reactions to - and thus dependent on - earlier events on which the historical event setting the chain in motion is at least partly contingent (Mahoney 2000; Pierson 2000b). To avoid the problem of infinite regress (i.e., the endless pursuit of contingent events or reasons), conjunctures - intersection points between two or more prior sequences - are often treated as the initial contingent occurrences (Mahoney 2000). Therefore, we concretely set out to uncover the sequence of events which have resulted in the contingent conjuncture that has since led to the three countries' current interest in QAE.

\section{Individual paths towards quality assurance and evaluation}

\section{Brazil: rapid pace towards assessment, slow pace towards quality}

Brazilian education is closely connected with the country's socio-economic and political development. During the centuries of colonisation (1500-1822) and decades of empire (1822-1889), schools were scarce and primary education was a luxury of the elite. The First Republic (1889-1930) introduced a federal 
system and consolidated educational decentralisation. The first Brazilian Constitution (1891) recognised the states as the main providers of basic education and made the federal government responsible for higher education (Romanelli 2007 [1978]).

Historically, federalism became associated with the democratisation and decentralisation of political power (e.g., Souza 2002). Democratisation and decentralisation, in turn, became discursively connected with regionalism. On the one hand, because of Brazil's huge area, "regionalism" describes the socio-cultural and linguistic diversity of its geographical regions. Decentralisation became tied to the regional diversity which shaped Brazilian identity. On the other, "regionalism" refers to regional inequality and disparities in population concentration, resources, and socio-economic and educational development. Decentralisation became tied to federalism, a political system which allows cultural heterogeneity while seeking to counter-balance, or accommodate, socio-economic heterogeneity (Souza 2002). However, by 1891, federalism was benefiting the autonomy of the states' oligarchies, weakening the federal government, increasing regional disparities, and creating disparate policies (Romanelli 2007 [1978]). The states failed to expand education policies, and gaps in education increased. The 1920 census showed a $72 \%$ illiteracy rate among the population over the age of five (Haddad \& Di Pierro 2000).

A growing urban middle class and an engaged intellectual community, with social discontent and the decline of the oligarchies, paved the way for the 1930 revolution, when there was a civil-political restoration (1930-1937). A synergy between educationalists' vigorous demands and democratic efforts led to a political commitment to education planning. The 1932 reform modernised secondary education (Dallabrida 2009). The 1934 constitution designated national education as the responsibility of the federal government, and the Ministry for Education and Health was created. Two key institutes were established: in 1934, the Brazilian Institute of Geography and Statistics (the IBGE, until 1937 the INE), and in 1937, the National Institute for Educational Studies and Research (the INEP, previously the INP). The IBGE provides Brazilian socio-economic indicators, census, and other statistics analysis; the INEP is responsible for all large-scale assessments and other education studies and data.

This intellectual and socio-political unity rapidly broke down, and both the education and political fields were fragmented in conflicting positions. In 1937, President Vargas installed a dictatorship (1937-1945), and the 1937 constitution reduced the government's responsibility for education. However, Vargas continued to see education as an instrument for the construction of the nation (Peixoto 1995), and the corporatist regime maintained ties with certain educationalists (Centeno 2010). The 1942 reform sought to respond to rising social demands for post-primary education and the requirements of industrialisation. The country still struggled with the provision of universal access to primary education. Despite growing enrolment rates, educational provision fell far short of meeting social demands (Oliveira \& de Araújo 2005). 
The Second Brazilian Republic (1946-1964) re-established civil rights. The 1946 constitution reaffirmed the government's responsibility for national education and legislated for compulsory free primary education. Populist governments emphasised a developmentalist industrialisation project, and education efforts concentrated on technical training at the expense of primary education (Centeno 2010). The states expanded their education systems; appropriate pedagogical-administrative planning was, however, absent (Nardi, Schneider, \& Rios 2014).

At the end of the 1950s, educationalists identified major education problems, some of which are still present: insufficient school expansion; lack of equal opportunities; high dropout and retention rates; inadequate infrastructure, materials, and curricula; and a largely untrained teaching body (Moreira 1956). In 1961, after thirteen years of lively debate, the first Education Law established common national guidelines. The main education indicators were the national census and statistics concerning school enrolment, dropouts, and retentions. QAE practices and policies were neither problematised nor envisaged until the 1970s, as elaborated elsewhere (Kauko et al. 2016).

Populist governments tried to accommodate social demands and allowed a vibrant education community but faced strong political and socio-economic instability. A society fragmented into sectors with divergent interests (Ianni 1975) was the backdrop for a military coup and dictatorship (1964-1985). The military governments restricted civil and political rights. Education initiatives were tailored to meet the government's ideological purposes and economic requirements. The government's alphabetisation programmes (MOBRAL) were particularly well-received by international organisations like the United Nations Educational, Scientific and Cultural Organisation (UNESCO).

Nevertheless, the lack of or insufficient planning for mass education raised serious issues at the state level. In the 1970s and 1980s, the states started to develop performance assessments to collect information about issues as diverse as teacher training, curricula, school materials, and students' progress (Gatti 1987). The World Bank collaborated with many of these state programmes (Gatti, Vianna, \& Davis 1991).

The Ministry of Education also supported programmes which improved school access and pupils' performance in the country's poorest regions (Horta Neto 2007). The most famous was the Northeast Basic Education Project (EDURURAL), which the Ministry of Education had planned in 1977 (Horta Neto 2007) but which was only implemented in 1980 with a loan from the World Bank. The first large-scale assessment involving more than one state was developed within this project in response to a request from the World Bank's project evaluation (Gatti, Vianna \& Davis 1991). In 1984, the Ministry of Education and the World Bank began conceiving the Second Northeast Basic Education Project, but the agreement was only signed after ten years of negotiations (Horta Neto 2007). Until the mid-1980s experiments with learning assessments in Brazil were discursively and pragmatically inconsequential and were still neither framed nor understood as QAE practices and policies. Indeed, 
the notion of quality was rather contested in the educational field because of its historical association with elitist education and political conservatism (Centeno, Kauko, \& Candido 2017).

With the end of the military dictatorship in 1985, socio-political movements and education debates returned (see Chapter 4). Brazil faced economic adjustments (Wirth 1997) and pressure from the international system, including the World Bank and the International Monetary Fund, to structurally reform. The transitional government began a managerial reform of public administration. Total quality management emerged as a particularly good solution for the country's managerial problems (Longo 1996). Although such programmatic incursion into education had little practical impact, it triggered an important public debate. While the education community strongly contested its application to education, policymakers, economists, and sociologists embraced the educational "total quality" perspective (Centeno, Kauko, \& Candido 2017). This discussion brought the notion of education quality to the fore. A new political discourse, in which quality in education was associated with assessment, emerged.

In the 1980s, instead of substantial reforms, the states attempted to regularise school progression (in other words, without retention) through measures such as automatic grade progression, the provision of acceleration classes, and the reorganisation of studies into cycles (Franco et al. 2007). These ad hoc and palliative policies compromised traditional statistical indicators and weakened trust in official statistics (Oliveira \& Araújo 2005). From the late 1980s, the United Nations Development Plan (UNDP) promoted the improvement of education information systems at both state and national levels. Projects in 1986 focused on managerial training for basic education, support for methodological development, and the provision of the State Secretariat of Education with the necessary equipment for data collection and analysis, besides staff training (Coelho 2008). The UNDP has been playing an important role in collecting, organising, and disseminating data, including education data (this culminated in "The Human Development Atlas in Brazil": see www.atlasbrasil.org.br/2013/ en/home/).

In 1987, the INEP designed a programme of external assessment to evaluate pupils in public schools (Vianna 1990) and provide information to the states about learning problems. The Ministry of Education and some states committed to this programme (Horta Neto 2007), but the project did not affect public policies as expected because of constant personnel changes in the Ministry of Education (Gatti, Vianna \& Davis 1991).

Nevertheless, this allowed the INEP to build its own expertise (see Chapter 5). This experience, together with the knowledge developed by the Ministry of Education in EDURURAL, facilitated the creation of the first nationwide large-scale assessment in 1988 (Horta Neto 2007): the Evaluation System of Public Primary and Lower Secondary Schools (SAEP). Resources for its planning and implementation were still sourced from a loan agreement with the World Bank (Coelho 2008), but the federal government postponed its launch 
for financial reasons (Gatti, Vianna \& Davis 1991; Horta Neto 2007). The SAEP provided the technical grounds for the assessment of basic education (Bonamino \& Sousa 2012). It was the first in an avalanche of national and international assessments which progressively covered the whole education system (see Kauko et al. 2016).

A strong democratic movement progressively and irreversibly took hold in the 1980s, leading to the 1988 constitution and the first direct presidential elections in 1989. Federalism, decentralisation, and democracy were again entangled in constitutional debate. The 1988 constitution reinforced federalism by empowering municipalities with responsibility for education, but it ignored its financial and political impact and fuelled federal conflict (Araújo 2010). Decentralisation resumed and strengthened. Where decentralisation to sub-national governments is concerned, Brazil is considered the most decentralised higherincome country (Souza 2002). The national education scheme was reorganised according to the government level, and school autonomy was progressively enforced (Meade \& Gershberg 2008).

An ambiguity concerning decentralisation is reflected in the proliferation of attitudes which see it as an obstacle or even as a factor in Brazilian education disparities (see Romanelli 2007 [1978]; Alves 2007; Dourado 2007; Franco et al. 2007; Goncalves \& Franca 2008; Sobreira \& Campos 2008; Souza \& Costa 2009; Durham 2010). However, for many who support national standard measures such as a core curriculum, decentralisation is still strongly tied to diversity, and references to a unified or centralised education system are therefore not only mistaken but also carry negative political connotations, which all actors, regardless of their position in the education arena, seem keen to avoid (as our interviewees vividly confirmed).

The text of the 1988 constitution also contributed to the understanding of education as an individual and social right. It guaranteed the universalisation of access to free compulsory basic education, equality of educational opportunities, and non-discrimination. However, it associated education quality with education assessment (Freitas 2004; Coelho 2008; Gusmão 2010). The assurance of quality became a central aim of education policy. Some held that the assessment of education quality by the government was a means of allowing private education to continue, while attempting to control it (Coelho 2008). The assessment of private schools logically implied the assessment of public schools (Freitas 2004). The SAEP was transformed into the SAEB (Evaluation System of Basic Education, see Chapter 7), "basic" replacing "public" to include assessment of private schools (Horta Neto 2007). The implementation of the SAEB in 1990 was assisted by the UNDP and funding from the World Bank (Coelho 2008).

In 1996, the National Education and Framework Law (LDB) entrenched the decentralisation of education, which was successively redefined by further amendments (see Law 9.394). Currently, municipal systems are broadly expected to provide pre-school and elementary education (for 1- to 14-yearolds), while the state systems are expected to cover the remaining compulsory education (for 15- to 17-year-olds). The federal government is responsible 
for providing the necessary technical and financial backing to federal units. However, municipal and state systems frequently overlap, and this (dis)articulation between the three levels still presents many problems (Candido, Kauko, \& Centeno submitted). Educational decentralisation has neither simplified education planning and political-fiscal mechanisms nor reduced inequalities between federal units, among the population, or even among schools (see Oliveira \& Santana 2010).

UNESCO and other international organisations supported the Brazilian educational reforms of the 1990s. The 1990s World Declaration on Education for All (EFA) and UNESCO's education quality agenda greatly influenced the education debate and the implementation of QAE mechanisms. The UNESCO Regional Bureau for Education in Latin America and the Caribbean (OREALC) hosted the Latin American Laboratory for the Assessment of the Quality of Education (LLECE), which began to conduct regional large-scale assessments in 1997.

The SAEB went through several technical changes. It was reformed (1995), consolidated (2005), and enlarged (2013). The UNDP continued to enable these methodological developments and the acquisition of expertise by financing INEP staff training (in Brazil and abroad) and facilitating international technical cooperation (see Coelho 2008). The UNDP employed - and still employs - Brazilian technicians and officials working in the INEP, for example (interview data). Despite the critiques of data production by the national government (see Chapters 5 and 7), assessments are frequently justified in the education arena as a counterpoint to the complex decentralised Brazilian system. Our interview material suggests that inequalities and disparities, with a lack of information and central control resulting from strong decentralisation, were the basis for the restructuring and expansion of QAE education policy between 2005 and 2009 (see Kauko et al. 2016).

Another fundamental development in QAE was the creation of a major index from the school census (statistical data) and SAEB data (students' achievements), the Development Index of Basic Education (IDEB), which is regarded as the main indicator of Brazilian education quality. The IDEB was developed alongside the 2007 Education Development Plan, which set the goal of achieving the OECD's Programme for International Student Assessment (PISA) mean score by 2021. The recent National Education Plan (PNE 2014-2024) reiterated this goal. The OECD and ETS (the Educational Testing Service leading the PISA consortium) trained Brazilian technicians in the early 2000s (interview data). Brazil has been vice-chair of the PISA Governing Board since 2013.

In the broader political and socio-economic context, Brazil entered the twenty-first century with a promising framework. For the first time since the end of dictatorship, Cardoso's stable democratic government (1995-2002) was in power. Cardoso tackled economic restructuring, implementing managerial and efficiency reforms in all sectors of public administration (Derqui 2001). Lula da Silva's Workers' Party government, which succeeded Cardoso, governed in a context of progressive socio-political growth (2003-2010). The Lula 
government ensured an unprecedented political continuity in Brazil. However, the socio-economic and political situation deteriorated rapidly during the next Workers' Party government of Dilma Roussef (2011-2016), which culminated in impeachment. Socio-political contestation and economic recession have continued under the Temer provisional government (2016 to present). Labour and social security reforms are internally highly controversial, although they are praised by international economic agencies and financial markets. The reform of secondary education provokes diverging opinions. Currently, the minimum wage is US $\$ 297$ and the unemployment rate continues to grow (hitting $13.7 \%$ in March 2017, IBGE). The media has described people's growing difficulties (e.g., Phillips 2017).

The Brazilian socio-political pendulum swung dramatically between democratic and authoritarian governments until the mid-1980s, but despite this socio-political turbulence, there was an expansion of education opportunities (e.g., Oliveira \& Araujo 2005, Klein 2006, Oliveira 2007, Gouveia \& Souza 2013). Since the 1990s, Brazilian education has been subject to relentless QAE policies. Although many - if not all - the problems experienced between the 1950 s and 1980s have persisted, educational progress has occurred. Despite the current turbulence, this is likely to continue. When we were in the field (2015/2016), Brazilian opinions about the future on the national level were hopeful (see Chapter 8), while locally they were very mixed (interview data). Currently, a broader pessimism can be sensed in informal local feedback from interviewees, and it is also noticeable in many media interviews with experts holding contrasting political and educational views (e.g., Daniel Cara, Folha de São Paulo, 10 October 2017; Ricardo Paes de Barros, Istoé Dinheiro, 8 September 2007).

The same education problems persist but with changes in their depth and breadth. As one interviewee concisely stated, improvements occur continuously but at a slow pace and appear to frustrate progress - always taking place but never matching initial expectations.

\section{China: imperial legacies and the needs of the party-state - "QAE with Chinese characteristics"}

The Chinese education system has been strongly influenced and shaped by Chinese cultural and intellectual traditions, especially Confucianism (Lee 2000). During the millennia-long imperial era, the state's direct involvement in education was very limited, and education was for the privileged few, even if formally everyone could achieve social mobility through the open civil service imperial examinations (keju), which also served as a rudimentary assessment system for future government officials (Han \& Yang 2001; Postiglione 2011). To this day, this heavy emphasis on examination performance looms over the education system, complicating many efforts at reform. During the imperial era, there was also a system called the inspection of learning (shixue), under which emperors and local governors acted as education inspectors (Hong 1991). After the 
abolition of the imperial education system in 1905, which was followed by the fall of the last imperial dynasty in 1912, foreign, and especially Western, supervision practices began to be studied and borrowed (Han \& Yang 2001; Lee 2000). Further development, however, was stalled for decades because of internal conflict, war, and social turmoil (Han \& Yang 2001).

It was this context of a decentralised elitist system with a huge illiterate population which allowed the Chinese Communist Party (CCP), established in 1921, to grow in influence (Postiglione 2011). After the rural-poor supported communist victory over the nationalists in the civil war the People's Republic of China (PRC) was established in 1949. The decentralised and largely private education system was nationalized, and the Ministry of Education took over as the highest central authority dealing with education issues (Hong 1991; Meisner 1999). This centralised model of education governance largely followed the Soviet model (Meisner 1999; Postiglione 2011). In the following decades, education policies fluctuated between the moderate and radical, mirroring the general political situation. In the most radical phases, even hinting about learning from Western capitalist countries was an offence approaching treason. To cater for the needs of the rural poor who had helped the Communist Party gain power, in the first decades of communist rule, education served mainly ideological, economic, and political requirements, and egalitarianism was the expected targeted standard (Chen Cravens, Chu \& Zhao 2011; Han \& Yang 2001). Throughout the country, education was uniformly organised and political orthodoxy was prioritised. The centralisation of the education system also covered matters related to supervision. An inspection office (shidaosi) took over the task of assisting education governance through the inspection of schools (Hong 1991). However, despite the communist victory in the civil war and the subsequent nationalisation of education, uncertain times continued. The restored supervision system and the rest of the education system were severely disturbed by the turmoil of the Cultural Revolution - the most radical of the early political campaigns of the People's Republic of China. According to the extreme leftists' view within the Chinese Communist Party, the revolution needed to be continued and deepened, as this task had been neglected after the establishment of the "New China".

It was only after Mao's death in 1976 that Deng Xiaoping, the country's new de facto paramount leader, began to restore the education system after the turmoil of the Cultural Revolution (Hong 1991; Postiglione 2011). Under his reforming leadership, China adopted an economic reform policy known as "Reform and Opening Up" (gaige kaifang). Opening the Chinese economy and society to foreign trade and ideas was essential to this programme so that "socialism with Chinese characteristics" - an economic system combining a traditional socialist politico-economic system with a market economy - could be established (Meisner 1999). In reforming the Chinese economy with the help of foreign expertise - which now included ideas, practices, and products from the West - the revitalisation and reform of the education system played a central part. Education became a strategic priority because of its crucial link 
with the promotion of national development and its furthering of the state's economic aspirations (Chen Cravens, Chu \& Zhao 2011). In a country where, despite the progress made during the Mao era, even basic infrastructure and access to education were severely lacking, efficiency and quality of education were naturally defined in quantitative terms. Later the focal points of this quantitative improvement, with its twin goals of universalising nine-year compulsory education and eradicating illiteracy, became known as the "Two Basics" (liangji) (Postiglione 2011).

To ensure that these quantitative improvements would succeed, the supervision system also had to be re-established. Consequently, in 1983, the Ministry of Education released a formal document calling for the re-establishment of education supervision in all provinces. The legal framework guiding the work of supervision has since been completed (Yang 2001; Dahlman, Zeng, \& Wang 2007). Under this model, the supervision system (dudao) has two basic purposes: administrative (duzheng) and education inspection (duxue). Administrative inspection is tasked with ensuring that local governments fulfil their responsibility to provide the necessary funds, facilities, and resources for the development of education. Education inspection in turn is intended to ensure that schools follow relevant education laws and policies (Huang 2009; Jin 2004; Yang \& Guo 2005). A four-layered supervision network extending from the national to sub-national city and county levels has slowly been implemented (Hong 1991; Lee, Ding, \& Song 2008).

With the help of the re-established supervision system, China was able to achieve most of the goals of the "Two Basics" by the end of the twentieth century - a feat rarely achieved by other developing lower-income countries (Chen Cravens, Chu \& Zhao 2011; Postiglione 2011). Meanwhile, economic reform had succeeded in launching the People's Republic of China on an unprecedented trajectory of double-digit economic growth, which helped pull hundreds of millions of Chinese out of poverty - a remarkable feat by any standard (Meisner 1999). However, exposure to Western ideas and marketoriented reforms also brought new problems. Income inequality, inflation, and corruption increased, and demands for political reform strengthened during the 1980s. The decade's ensuing political unrest culminated in the 1989 crackdown on the Tiananmen Square protest in Beijing. The Chinese Communist Party has been greatly preoccupied with its legitimacy ever since, and consequently, to legitimise itself and stay in power, maintaining economic growth, social stability, and national unity have been the party-state's top priorities (Laliberté \& Lanteigne 2008; Zhu 2011). As Chapter 4 illustrates in more detail, a cautious stance towards foreign influence remains perhaps the most enduring legacy of the unrest of 1989, because it is seen as a major contributor to the unrest.

Although economic growth initially slowed after 1989, education reform to maintain it has only intensified since the 1990s (Postiglione 2011). As the basic quantitative targets had largely been achieved by then, reflecting a larger societal trend whereby all human resource decisions were justified in terms of quality, emphasis in education increasingly shifted from quantitative to qualitative 
improvement (Kipnis 2006; Law 2007; Liu 2008). Following this shift in focus, and largely inspired by academics now familiar with Western ideas and practice, the notion of "quality education" (suzhi jiaoyu) appeared in the education agenda. The notion gained momentum in the 1990s as a guiding principle of education policy, and it soon became a catchphrase for Chinese policymakers, the media, and the general public (Chen Cravens, Chu \& Zhao 2011; Della-Iacovo 2009; Kipnis 2006). Since its first appearance in the mid-1980s, the wording has been used in policy resolutions and reform plans, and in the revised (2006) version of the 1986 Compulsory Education Law, quality education was promoted from a policy to the legal level for the first time (DellaIacovo 2009; Law 2007; Liu 2008). Consequently, new policy orientations place more emphasis on efficiency, practicality, plurality, students' all-round development, and the measurement of student and school outcomes, although the ultimate goal of quality education is still to assist the party-state in its quest for national rejuvenation (Chen Cravens, Chu \& Zhao 2011; Han \& Yang 2001; Della-Iacovo 2009, Xin \& Kang 2012). As Belinda Della-Iacovo (2009: p. 242) explains,

The ultimate goal of suzhi jiaoyu is national strength. The government has identified the skills China's workforce needs to acquire which it sees as critical to sustaining its modernisation drive. Practical skills and innovative ability have been identified by the leadership as areas which need to be improved in order to raise China's global competitiveness.

In addition to this qualitative turn, other notable changes also took place in the Chinese education field around the same time. First, following a broader shift in Chinese society towards market practices, the education system also became increasingly market-driven as a result of a policy known as "entrepreneurialising education" (jiaoyu chanyehua), which emerged in the late-1990s (Ngok 2007; Qi 2011). As Gerard A. Postiglione (2011: p. 85) asserts, "Markets have come to matter more than Marxism in educational provision, especially as more needed to be paid for quality education". Second, by the early 2000s, the idea of a "scientific outlook on development" (kexue fazhan guan) was gaining ground in the political leadership. These ideas consolidated the notion that policymaking in the field of education should also be based on evidence and science (Chen 2010; Zhang 2010; Xu \& Li 2011).

With the change in the definition of quality in education, new measures to ascertain that it is achieved have been required. Consequently, the reform of the testing, evaluation, and assessment system has played a central role in promoting and improving the quality of the education system (Han \& Yang 2001; Liu 2008; Peng, Thomas, Yang \& Li 2006; Xu \& Li 2011). Most notably, this change has manifested itself in the construction of the assessment (jiance) system headed by an institution known as the National Assessment of Education Quality (NAEQ, Jiaoyubu Jichu Jiaoyu Zhiliang Jiance Zhongxin), which was piloted in 2007. This formally independent system managed by the NAEQ 
runs in parallel with the supervision system by operating on the four already mentioned levels. However, its main purpose differs from that of supervision. The jiance system is tasked with gathering data through standardised tests, which are then utilised in policymaking and system development (Chen 2010; Fan \& Liao 2013; Wang \& Zhang 2009; Zhang 2010; Zhou 2012). Rhetorically at least, this assessment plays a central role in contemporary Chinese compulsory education. We examine the system's various aspects, as well as its disparity between rhetoric and practice, in more detail in Chapters 4 and 6. Several other reforms, such as curriculum reform, which touch on QAE have also been initiated.

At the beginning of the twenty-first century, the People's Republic of China is arguably both politically and economically a regional and global powerhouse. China's share of world gross domestic product has risen to double digits, and after four decades of economic reform, the Chinese population has become increasingly rich. Access to all levels of education has grown exponentially, and illiteracy among young people has been virtually abolished. Many problems persist, however. Despite the economic progress of the last forty years, political reform has lagged. No change has been made to the fundamental structure of the political system since the events of 1989, and the ultimate authority to make policy still resides with the Chinese Communist Party. This is also evident in the field of education, where regulations and overall plans are still largely formulated by the Ministry of Education, whereas sub-national authorities are mainly responsible for implementing policies by adapting to local conditions (which sometimes entails risking the circumvention of central policies) (Postiglione 2011; Qi 2011). Although some flexibility and innovativeness are allowed, all local adaptations must be done within the general framework, and it is primarily the workload - not the authority - which has been transferred downwards (Harris, Zhao, \& Caldwell 2009; Ngok 2007; Qi 2011). Tingting Qi (2011: p. 34) has aptly described this phenomenon as "centralised decentralisation". Although the fundamentals of the system remain unchanged, this does not mean everything has remained the same. Jessica C. Teets (2013) has noted that a new model of state-society relationship, which she calls consultative authoritarianism, is emerging in Chinese society at large. She suggests (ibid.: p. 32) this reformed form of governance

merges the regulatory-state idea of a relatively autonomous civil society collaborating with the state to solve social problems with the New Left idea of state guidance of groups to protect society from narrow interest groups and social instability. This model is characterized by two main aspects - a pluralistic society participating in policy formation and implementation, and the use of multiple indirect tools of state control.

As we shall see in Chapter 4, these tendencies have also been evident in the structure of the current QAE system in Chinese compulsory education as new stakeholders in the field have emerged. The continued emphasis on testing and 
examination performance, which dates to imperial times, still largely structures systems (Postiglione 2011). As our interviews also indicated, the influence of these practices is so strong and pervasive that wordings such as promotionoriented education (shengxue jiaoyu) or examination-oriented education (yingshi jiaoyu) are today staple features of the vocabulary of Chinese educational discourse: the perceived negative influences of these continuing practices were frequently mentioned by our interviewees. Resource issues also persist. Many rural schools still lack qualified staff and facilities (Robinson \& Yi 2008). Indeed, the economy's exponential growth has given rise to new types of inequality. There is not only a gap between different areas and provinces today, but the gap between counties and even schools - of which a growing number are now privately run - in the same locality is continually growing (Gustafsson, Shi, \& Sicular 2008; Huo \& Gao 2006).

\section{Russia: quality control reinforcing central regulation ${ }^{1}$}

School education in Russia has been facilitating state development projects since the tsarist era. Two distinct societies and cultures, the elite and the peasantry, co-existed in imperial Russia, and by the beginning of the twentieth century, teachers in peasant schools were expected not only to spread literacy but also to play the role of political mediators, who would assist in the implementation of the state's political and economic strategy for Russia's vast rural community (Seregny 1993: pp. 121-122). In Soviet Russia, education was of major importance to the effort to build a society of egalitarianism and solidarity. Schools were to equip students with everything needed for their effective future contribution to the socialist economy and to the project of building communism. Hence, alongside the development of students' skills and knowledge, schools were involved in ideological indoctrination. The Stalinist school model was developed in the 1930s after a decade of pedagogical experiments, and it reinstated many aspects of pre-revolutionary education, such as the teacher's dominance of the classroom and strict adherence to a centralised curriculum (Byford \& Jones 2006: p. 422). The main characteristics of the Stalinist school were rigid discipline and hierarchy, the enormous quantity of information students were expected to absorb, and an emphasis on collectivism and patriotism. The state assumed full responsibility for guaranteeing free and equal access to education, as well as its quality. At the same time, it was the duty of every (future) citizen to attend school and to study to the best of his or her ability to develop into an efficient member of socialist society (Livschiz 2006: p. 559). Students' commitment to learning was overseen by school workers, student organisations in which every student was enrolled from grade one, and local organs of the Communist Party, which exerted influence over parents at their workplaces.

The main instruments of quality control during the Soviet era were inspections, school reports, and the school census. In 1944, a system of grades and examinations was established. Students' outstanding results were symbolically 
rewarded with gold and silver medals. There was no centralised national examination, and school-leavers' educational achievements were assessed by schools under the supervision of the local education authorities. It was assumed that a centralised curriculum and teacher training, given that schools were provided with sufficient resources, effectively ensured a high standard of education and its relevance to the current needs of the state (West \& Crighton 1999). Until the education reforms of the 2000s, the grades of students and their related indicators, such as the percentage of students successfully transitioning to the next school year or the numbers of graduates awarded medals, served as the main measures of quality (see e.g., Bakker 1999: p. 296). Assessment of schools and teachers on the basis of students' grades was prohibited by the decrees of the 1940s, and competition in socialist education was discouraged (Mayofis 2015: pp. 40-41). Regular school inspections ensured teachers' objectivity in their assigning of grades:

The mark ... should reflect the true knowledge of students. When fighting the poor progress of students, one should not follow the path of lowering the standards, as some teachers tend to do. Only through raising the standards the quality of knowledge can be improved.

(from an article in the Teacher's Newspaper, 1948, quoted in Mayofis 2015: p. 82)

Despite the appearance of state control over every aspect of school life and the constant improvement in quality, Soviet education faced many challenges. The country's vast size, its social and ethnic diversity, and the enormous differences between the Soviet city and countryside contributed to the large variety of implementation methods for centrally designed education policies. In the aftermath of the economic and social devastation of collectivisation and World War II, schools were severely underfunded, and post-war state statistics registered massive dropouts and repeating of study years (Livschiz 2006). Teachers were blamed for this: they were accused of "formalistic" teaching approaches and lacking the necessary pedagogical skills (Mayofis 2015: pp. 61-64). Between 1940 and 1956, schools charged tuition fees for grades 8-10, making education at this and higher levels virtually unaffordable to poorer families, especially in rural areas. Studies of Soviet education consistently point to its persistent inequality (Byford \& Jones 2006).

Ideas about the mission of education in Russia started to change under perestroika in the 1980s. The key idea of perestroika was to reorganise the social and political sphere to allow for more freedom and truth. In education, this was interpreted as a call for more democratic and student-centred schools. A group of educators within the Academy of Pedagogical Sciences, called VNIK "Bazovaia shkola", proposed a critical reform of the Soviet school. They suggested a set of new basic principles: democratisation, humanisation, differentiation, openness, continuity, and a developmental approach to education. They also promoted greater participation by school staff in a wide range of decisions 
concerning schoolwork, claiming that "educational processes should be governed by those who teach" (Long \& Long 1999: p. 88). School administration was envisioned as a communal enterprise which should involve students and parents, as well as teachers and civil society representatives, to better serve local needs. Another phenomenon of the 1980s which facilitated education reform was the movement of "innovative teachers" (pedagogi-novator $y$ ). These teachers offered creative teaching methodologies with a focus on students' individual abilities and interests, demonstrating that this greatly increased students' learning. In 1986, they formulated the proclamation of "Cooperative Pedagogy", based on partnership between teacher and student. The concepts and methodologies of innovative teachers were disseminated in courses, seminars, and media sources.

The ideas advocated by VNIK and innovative teachers became the basis of the new Law on Education in 1992, following the dissolution of the Soviet Union. The leader of VNIK, Eduard Dneprov, became the first minister of education in post-Soviet Russia. The new law also enabled the decentralisation of education to support school-level management, allow schools to tailor the curriculum to local needs, and facilitate school choice for families. The government's administrative and fiscal responsibilities were shifted to regional and local education authorities. However, the call for democratisation, humanisation, and differentiation was not the only factor in the dramatic changes in Russian education. The economic crisis of the early 1990s caused severe underfunding. The abrupt transition to a market economy led to the reinterpretation of education as a service and the partial privatisation and commercialisation of the school sector. Alongside the legislation for decentralisation, inequality in education sharply increased (Polyzoi \& Dneprov 2011).

While the central authorities lacked financial resources, new education initiatives were financially supported by international philanthropic foundations, especially the Soros Foundation (Startsev 2012). Other international organisations, including the World Bank and the OECD, started working in Russia in the 1990s. They encouraged efforts to democratise and differentiate education and suggested the implementation of a more thorough and modern system of quality assurance, which would include nationwide quality standards and external quality evaluation mechanisms and involve diverse stakeholders in the QAE process (OECD 1998; World Bank 1999). World Bank experts regarded the lack of standardised achievement testing providing commensurable national statistics as an absence of QAE policy (World Bank 1995). Both the World Bank and the OECD recommended standardised testing as a key quality evaluation mechanism. At the same time Russia started participating in international large-scale assessments, TIMSS (Trends in International Mathematics and Science Study) was undertaken in 1995 and 1999, and Progress in International Reading Literacy Study (PIRLS) and PISA were added in the 2000s. The methodology of these tests and their sociological perspective served as a source of inspiration for Russian scholars, who conducted meta-analyses of test results and designed similar national instruments (Piattoeva \& Gurova 2018). 
Ideas about education quality and its evaluation changed in line with the developments of the 1990s. Quality came to be understood as intrinsically diverse, based on "customer" needs and context-bound. Assessments were addressed primarily as a tool for school and classroom internal diagnostics with the overarching aims of the effective management of schools and meeting the needs of students and parents. At the same time, the literature on school management published in this period promoted an evidence-based and goaloriented approach and insisted that education outcomes, although specific to each school, should be measurably defined and accompanied by a set of indicators (e.g., Tret'iakov 1997). The development of measurements in education was also powered by an increasing interest in ability testing, which had been banned during the Soviet era, and the rise of information technologies, which opened new possibilities of collecting and processing large quantities of data. While these new ideas were not reflected in the education legislation of the 1990s, they arguably prepared the ground for the changes of the following decade.

At the beginning of the 2000s, with the recovery and growth of the Russian economy and change in political leadership, new education reforms were launched. The Ministry of Education issued several key documents: the National Doctrine for Education (2000), the Concept of Modernization of Russian Education (2001), and the Federal Strategic Program for the Development of Education (2005). These documents defined the mission of education primarily in economic terms: education should contribute to socio-economic growth, serve the needs of the labour market, promote innovation, and ensure the global competitiveness of the Russian economy. They supported the further introduction of market mechanisms to the education sector and called for efficiency, accountability, and transparency in education. These ideas accorded with the recommendations of international organisations and were in line with general performance management reforms in Russia (Gounko \& Smale 2007; Gusarova \& Ovchinnikova 2014). In 2001, the World Bank started its Education Reform Project in Russia, aiming to "improve quality and standards; promote the efficient and equitable use of scarce public resources for education; modernize the education system". The project was launched at the federal level and piloted in three Russian regions. Its intention was to introduce quality monitoring and statistics, based on a new system of assessing student outcomes in the governance of general education (World Bank 2001).

Several major instruments of quality assurance and evaluation were introduced in the educational reforms of the 2000s. The Ministry of Education outlined "state standards", to which school curricula were obliged to conform. New procedures for the licensing, attestation, and accreditation of educational institutions were developed, ensuring schools and universities complied with central regulations and produced satisfactory results. In 2001, the national school-leaving examination (the Unified State Exam, USE, or GIA-11) was piloted in several regions, and in 2009, it became compulsory for all schoolleavers. The examination combined the functions of the school graduation test, the national university entrance test, and the source of national statistics 
on educational achievement (see Chapter 8 for more details on the USE). The Unified State Exam was claimed to facilitate fairer access to universities by assessing school-leavers objectively and impartially and to improve the quality of education across the country, fostering compliance with the official curricula. Thus, the USE was designed to contribute to greater equality for school-leavers and address the negative effects of the radical decentralisation of the 1990s. It also served as an important source of objective information for evidence-based policymaking, which was perceived as indispensable for modern regulatory methods. The national academic discussion between 2000 and 2010 also shifted its focus from school-based, customised evaluation of a largely qualitative nature to depersonalised, often numerical data on educational achievement generated by national and international assessments.

The latest State Program for Education Development (for the years 2013 to 2020) includes a programme for "the development of the system of quality evaluation of education and transparency of the education system" as one of its main elements. The national QAE system outlined in this document comprises action for the state regulation of education, assessment of educational achievement (the national examinations (GIA) after grades 9 and 11), procedures for independent quality evaluation, and the participation of Russia in international studies (Government of Russia 2012: p. 218). Quality of education is defined primarily as compliance with state standards and high performance in international tests. Scores in national examinations serve as the main indicators of education quality at all governance levels, although the examinations' contents, procedures, and administrative uses continue to be discussed and altered. During the last decade all-Russia measurements of educational achievement have been added to the QAE system to complement national examinations and international studies.

The introduction of QAE instruments facilitated the restoration of centralisation in Russian education. Evaluation procedures and associated performancebased incentives were added to the traditional instruments of quality control, instead of replacing them. Despite appearing to be piloted, national examinations were implemented consecutively in all regions of the country in an authoritarian manner. The state defines quality criteria and controls as both inputs (through institutional accreditation and audit) and outputs (through measurable outcomes) of general education. Researchers argue that Russian education reforms can be characterised as "authoritarian modernisation" and that a neoconservative turn is taking place, legitimised by a neoliberal, apparently Western, rhetoric (Minina 2016). At the same time, the current school system shows significantly more diversity and inequality than in the Soviet era, while national regulations still allow for considerable local variation in implementation. Contemporary education governance in Russia, including QAE instruments, evinces a mixture of Soviet-era legacies, developments from the democratisation and diversification period of the 1990s, and neoliberal influences. 


\section{Identifying commonalities and differences in paths to QAE}

As our work indicates, Brazil, China, and Russia have followed - and to a large degree continue to follow - very different developmental paths in their sociopolitical contexts and in the place of education within the larger contexts of politics and governance. However, towards the end of the twentieth century, the countries' paths intersected as they were shaped by a shared interest in QAE. In each country, a contingent conjuncture can be identified in which different developments converged to shape this interest.

In Brazil, this conjuncture dates to the late 1980s. QAE practices emerged at the same time as massive school expansion, deepening federalism and decentralisation, increased democratisation, public managerial reforms, and cooperation with international organisations. Unplanned development of school access and significant dropouts and retention rates presented a problem, while the democratisation of the country and the consequent political acknowledgement of education as a social right provided a legitimate political framework. The ongoing managerial reforms and experiments with assessments funded by the World Bank and supported by the UNDP offered a solution. The intersection of these contingent developments formed the breaking point which set in motion the implementation of the Brazilian QAE system, which was largely composed of large-scale assessments and quantitative indicators. QAE is viewed ambivalently in the education arena because, although it is criticised by many, it is also recognised as an instrument which can tackle the disparities and inequalities which, despite much progress in education, are still deeply rooted in Brazilian society.

In China, the conjuncture can be traced roughly to the period between the mid-1990s and the early 2000s. First, with the help of established institutions like examinations and the re-established supervision system, the quantitative targets of the "Two Basics" had been largely achieved by then. Second, maintaining economic growth had begun to play an increasingly important role in the party-state's drive to enhance its legitimacy after 1989, while the reform of the education system was crucial to the creation of economic growth. Third, the opening of Chinese society to the world brought new ideas. On the one hand, a growing number of Chinese had become familiar with Western education practice and, as Chapter 4 elaborates, international organisations were also increasingly active in the education field. The notion of quality education suzhi jiaoyu - rose to the national agenda. On the other, ideas about the marketisation of education and the idea of evidence-based policy were also gaining ground. These new ideas changed how quality in education was defined, which in turn directly contributed to the reforms of the QAE system - most notably, the establishment of the jiance system - as new mechanisms to ensure quality were required. However, these processes are by no means complete. Chinese society and education face new and continuing problems. 
In Russia, the conjuncture occurred at the end of the 1990s, when national movements for greater diversity and student-centred education, political concerns of increasing inequality and decentralisation, and international examples of and recommendations for large-scale assessments of student achievement converged. Humanisation and democratisation, as part of the de-Sovietisation of schools, led to a focus on student learning, a diversification of curricula and teaching methods, and the accountability of the school to a wide range of stakeholders. Education inequality increased dramatically because of severe underfunding, the marketisation of education, and a widening of social and economic gaps between families. By the end of the 1990s, the introduction of regional autonomy and transfer of administrative and fiscal responsibilities to local authorities had resulted in widely varying conditions and education practices in different regions. These factors contributed to what the public perceived as an education crisis, and justified the re-instatement of central control over education quality and the quality assurance of education opportunities, both of which had been long-standing prerogatives and social obligations of central government. Participation in international student achievement assessments also contributed to the development of national measurement instruments, and advice from the World Bank and OECD promoted modern regulatory instruments, especially standardised testing, as a source of evidence for policymaking. These developments in the early 2000s resulted in the establishment of a new QAE system based on state standards and national school-leaving examinations. The education system was recentralised through new regulation and under the motto "equal access to quality education".

From increased democratisation in Brazil to concern about regime legitimacy in China and de-Sovietisation in Russia, to name only a few examples, these developmental paths clearly reflected the unique cultures and political systems of the countries. QAE arose as a response to markedly different problems. However, these paths share some distinctive similarities, some of which are evident in all cases. First, in all cases, increased international influence and cooperation played a striking role in the introduction of QAE. Second, in all cases, the marketisation of education and public managerial reforms were an important constitutive factor. Some similarities were either identifiable or more evident in two cases. Although not a factor contributing to interest in QAE per $s e$, it is noteworthy, first, that this interest in QAE did not emerge entirely simultaneously: in Brazil, changes were already evident in the late 1980s, whereas they followed in China and Russia a decade later. Second, China and Russia also resembled each other in the sense that the change at this time towards more student-centred education thinking played a pivotal role in both. Third, the massive education expansion of the previous decades was especially important in Brazil and China. Finally, and most obviously in Brazil and Russia, anxiety about the decentralisation of the education system was also an important factor in growing interest in QAE.

Paths converged only temporarily, as this and the following chapters show. Not only had shared interest in QAE arisen in response to markedly different 
challenges and problems, but also, once operationalised, QAE reforms reflected the obstacles and limitations set by the very different cultural and political settings of the respective countries. Consequently, as the following chapters elucidate, since they were operationalised, QAE reforms in Brazil, China, and Russia have again diverged.

\section{From norm takers to norm makers in the global environment?}

While all this was happening within the countries, they had also begun to engage increasingly with the international community. Brazil had been engaging with international organisations since World War II, and by the 1990s, China and Russia were also involved (see Chapter 4). By 2017, all were members of the most prominent and influential global governance institutions, for example, the International Monetary Fund (IMF), the United Nations, the World Trade Organisation, and the World Bank. To borrow the words of $\mathrm{Pu}$ (2012), the countries had gradually become socialised within the international order as responsible norm takers. Since the turn of the millennium, however, there have been signs that Brazil, China, and Russia are no longer content simply to engage with the international community and follow its rules. There are signs that socialisation has become a two-way process, as emerging countries aspire to become norm makers in the international order ( $\mathrm{Pu} 2012$ ). Part of this drive has been the construction of a network of global governance institutions which in part complement and in part compete with the current US and Western-dominated system. With three former Soviet Republics, China and Russia founded the Shanghai Cooperation Organisation in 2001 to further their political, economic, and military cooperation. In 2016, the Asian Infrastructure Investment Bank was launched as a Chinese-sponsored alternative to the World Bank, and in South America, Brazil played a central role in the establishment of the Union of South American Nations. These initiatives belong to the larger global context of increasingly numerous and influential emerging power alliances, which are not limited to the activities of Brazil, China, and Russia (Bava 2011).

Within this wider context, perhaps most notably and interestingly because of their shared membership, the countries are also cooperating under the BRICS framework. In 2001, the acronym BRIC was used for the first time to group Brazil, Russia, India, and China, and five years later, a political dialogue between the countries began. The acronym BRICS was coined in 2010 with the inclusion of South Africa (Keukeleire \& Hooijmaaijers 2014; Pant 2013). Initially, as Luckhurst (2013: p. 252) states, the countries were lumped together because of "the dramatic economic growth predictions for the original four BRICs; the likely importance of their future governance role in the world economy; and the nature or quality of the development of these countries". Since the genie escaped the bottle, justifications for grouping these countries together have been numerous, ranging from their developmental requirements to their 
military stances. From the outset, however, academics, journalists, and politicians have been divided on the grouping's nature, justification, and prospects (Brütsch \& Papa 2013).

It is obvious, however, that the countries themselves have exploited perceptions of imminent commonality. The global financial crisis which began in 2007-2008 provided them with the ideal opportunity to develop common positions highlighting the contrast between a prospering periphery and a struggling core. The historic IMF quota reforms and the threat of a joint walkout from the 2009 United Nations Climate Change Conference if their common minimum position was not accepted served as ideal opportunities to symbolically highlight the "rise of the rest" narrative (Liu 2016; Pu 2012; Stuenkel 2014; Ünay 2013).

The BRICS remain a somewhat informal cooperation platform. However, China and Russia seem especially eager to push their cooperation in a more formal direction (Liu 2016). The establishment of the New Development Bank in the summer of 2014 as an alternative to the World Bank and the IMF and the launch of the "eThekwini Action Plan" to address issues related to foreign policy cooperation mark the first steps on this road (Keukeleire \& Hooijmaaijers 2014; Liu 2016; Stuenkel 2014). Those who question the validity of grouping the countries based on their similarities are for the same reason also sceptical, however, of the prospects for their effort to strengthen cooperation and further institutionalise the BRICS (see, for example, Liu 2016).

Although the BRICS grouping has largely been seen (and has portrayed itself) as politico-economic, there are signs that the countries have begun to cooperate in other areas under the BRICS umbrella - including education. Russia and China, for example, have initiated a platform for higher education cooperation which has been described as aiming "to become a platform for academic and expert cooperation, comparative research, and international educational projects" (Higher School of Economics 2013). Most important, perhaps, the BRICS countries' ministers of education meet regularly to promote education cooperation. At their autumn 2016 meeting, the New Delhi Declaration on Education was unveiled to promote cooperation in education. The declaration included - at least rhetorically - areas of cooperation such as "quality education" and "quality assurance" (The Indian Express, 30 September 2016; Xinhua, 30 September 2016).

Research focusing explicitly on the link between education and the BRICS countries has been scarce, however, and has so far been concerned exclusively with higher education (see, for example, Altbach \& Bassett 2014; Carnoy et al. 2013; Schwartzman, Pinheiro, \& Pillay 2015). Although we do not explore this further ourselves, we hope our contribution paves the way to such new research ventures.

\section{Note}

1 This section draws on earlier research articles, namely Gurova (2017) and Gurova, Piattoeva, and Takala (2015). 


\section{Bibliography}

Altbach, P. G., \& Bassett, R. M. (2014). Nix the BRICs - at least for higher education scholarship. Change: The Magazine of Higher Learning, 46(5), 30-33.

Alves, F. (2007). Qualidade da educação fundamental: integrando desempenho e fluxo escolar [Quality of elementary education: Integrating performance and school flow]. Ensaio: Avaliação e Políticas Públicas em Educação, 15(57): 525-542.

Araujo, G. C. (2010). A relação entre federalismo e municipalização: desafios para a construção do sistema nacional e articulado de educação no Brasil [The relationship between federalism and municipalization: Challenges for the construction of a national and articulated education system in Brazil]. Educação e Pesquisa, 36, 389-402.

Bakker, S. A. (1999). Educational assessment in the Russian federation. Assessment in Education: Principles, Policy \& Practice, 6(2), 291-303.

Baumgartner, F. R., \& Jones, B. D. (2009). Agendas and Instability in American Politics (2nd ed.). Chicago, IL: Chicago University Press.

Bava, U. S. (2011). Emerging power alliances in perspective: IBSA, BRIC, BASIC. In F. Kornegay \& L. Masters (Eds.), From BRIC to BRICS (pp. 55-61). Pretoria: Institute for Global Dialogue.

Bonamino, A., \& Sousa, S. Z. (2012). Three generations of assessments of basic education in Brazil: Interfaces with the curriculum in/of the school. Educação e Pesquisa, 38(2), 373-388.

Brütsch, C., \& Papa, M. (2013). Deconstructing the BRICS: Bargaining coalition, imagined community, or geopolitical fad? The Chinese Journal of International Politics, 6, 299-327.

Byford, A., \& Jones, P. (2006). Policies and practices of transition in Soviet education from the revolution to the end of Stalinism. History of Education, 35(4-5), 419-426.

Candido, H. H. D., Kauko, J., \& Centeno, V. G. (submitted). How has quality in education been problematised in Brazil? Resubmitted after revisions.

Capano, G. (2009). Understanding policy change as an epistemological and theoretical problem. Journal of Comparative Policy Analysis: Research and Practice, 11(1), 7-31.

Carnoy, M., Loyalka, P., Dobryakova, M., Dossani, R., Froumin, I., Kuhns, K., \& Wang, R. (2013). University Expansion in a Changing Global Economy: Triumph of the BRICs? Stanford: Stanford University Press.

Centeno, V. G. (2010). Agency in establishing a transnational space: Brazilian interest in USAmerican educational assistance programs (1956-1974). In U. Engel \& M. Middell (Eds.), World Orders Revisited (pp. 155-176). Leipzig: Leipziger Universitätsverlag.

Centeno, V. G., Kauko, J., \& Candido, H. H. D. (2017). Quality assurance and evaluation through Brazilian lenses: An exploration into the validity of umbrella concepts. Comparative Education, e-publication ahead of print. Retrieved from http://dx.doi.org/10.1080/ 03050068.2017.1348084

Chayes, A., \& Chayes, A. H. (1995). The New Sovereignty: Compliance With International Regulatory Agreements. Cambridge: Harvard University Press.

Chen, X. (2010). 中国的实践:基础教育监测的新尝试 [The Chinese practice: A new attempt at basic education monitoring]. 教育研究, 4, 3-4.

Chen Cravens, X., Chu, H., \& Zhao, Q. (2011). Defining school effectiveness in the reform for quality-oriented education. International Perspectives on Education and Society, 15, 153-185.

Cheng, K., Jin, X., \& Gu, X. (1999). From training to education: Lifelong learning in China. Comparative Education, 35(2), 119-129.

Coelho, M. I. M. (2008). Vinte anos de avaliação da educação básica no Brasil: aprendizagens e desafios [Twenty years of the evaluation of basic education in Brazil: Lessons and challenges]. Ensaio: Avaliação e Políticas Públicas em Educação, 16(59), 229-258. 
Cummings, W. (2003). The Institutions of Education: A Comparative Study of Educational Development in the Six Core Nations. Oxford: Symposium Books.

Dahlman, C., Zeng, D. Z., \& Wang, S. (2007). Enhancing China's Competitiveness Through Lifelong Learning. Washington, DC: World Bank.

Dallabrida, N. (2009). A reforma Francisco Campos e a modernização nacionalizada do ensino secundário [Francisco Campos' reform and the national modernization of the secondary school]. Educação, 32(2), 185-191.

Della-Iacovo, B. (2009). Curriculum reform and "Quality Education" in China: An overview. International Journal of Educational Development, 29(3), 241-269.

Derqui, J. M. G. (2001). Educational decentralization policies in Argentina and Brazil: Exploring the new trends. Journal of Education Policy, 16(6), 561-583.

Dourado, L. F. (2007). Políticas e gestão da educação básica no Brasil: limites e perspectivas [Policies for and management of basic education in Brazil: Limits and perspectives]. Educação E Sociedade, 28(100), 921-946.

Durham, E. R. (2010). A política educacional do governo Fernando Henrique Cardoso: uma visão comparada [The educational policy of the Fernando Henrique Cardoso government: A comparative view]. Novos Estudos - CEBRAP, 153-179.

Fan, Y., \& Liao, Q. (2013). 基础教育质量监测: 国际经验与本土路向 [Basic education quality monitoring: International experiences and the local path]. 教育导刊, 4, 37-40.

Franco, C., Ortigão, I., Albernaz, Â., Bonamino, A., Aguiar, G., Alves, F., \& Sátyro, N. (2007). Qualidade e eqüidade em educação: reconsiderando o significado de "fatores intraescolares" [Quality and equality in education: Reconsidering the meaning of "withinschool factors"]. Ensaio: Avaliação e Políticas Públicas em Educação, 15(55), 277-298.

Freitas, D. N. T. de (2004). Avaliação da educação básica e ação normativa federal [Basic education evaluation and federal regulatory actions]. Cadernos de Pesquisa, 34(123), 663-689.

Gatti, B. A. (1987). Testes e avaliações do ensino no Brasil [Tests and school evaluations in Brazil]. Educação e Seleção, 16, 33-41.

Gatti, B. A., Vianna, H. M., \& Davis, C. (1991). Problemas e impasses da avaliação de projetos e sistemas educacionais: dois casos brasileiros [Problems and bottlenecks of project evaluation and educational systems: Two Brazilian cases]. Estudos em Avaliação Educacional, 4, 7-27.

Glosny, M. A. (2010). China and the BRICs: A real (but limited) partnership in a unipolar world. Polity, 42(1), 100-129.

Gonçalves, F. O., \& França, M. T. A. (2008). Transmissão intergeracional de desigualdade e qualidade educacional: avaliando o sistema educacional brasileiro a partir do SAEB 2003 [Intergenerational transmission of inequalities and education quality: Evaluating the Brazilian education system from the perspective of SAEB 2013]. Ensaio: Avaliação e Políticas Públicas em Educação, 16(61), 639-662.

Gounko, T., \& Smale, W. (2007). Modernization of Russian higher education: Exploring paths of influence. Compare: A Journal of Comparative and International Education, 37(4), $533-548$.

Gouveia, A. B., \& de Souza, Â. R. (2013). Efetividade da política para o ensino fundamental em municípios Brasileiros [Political effectiveness for elementary education in Brazilian municipalities]. Cadernos Pesquisa, 43(150), 836-855.

Government of Russia. (2012). Gosudarstvennaia programma Rossiiskoi Federatsii "Razvitie obrazovaniia" na 2013-2020 gody [State programme of the Russian Federation "Development of Education" for 2013-2020]. Retrieved from http://минобрнауки.рф/документы/3409/ файл/2228/13.05.15Госпрограмма-РазВитие_образоВания_2013-2020.pdf

Gurova, G. (2017). Soviet, post-Soviet and neoliberal: Governing Russian schools through quality assurance and evaluation. Policy Futures in Education. Retrieved from https://doi. org/10.1177/1478210317743648 
Gurova, G., Piattoeva, N., \& Takala, T. (2015). Quality of education and its evaluation: An analysis of the Russian academic discussion. European Education, 47(4), 346-364.

Gusarova, M., \& Ovchinnikova, M. (2014). Introducing performance management in the system of public administration in Russia: Approaches and lessons learnt from the last decade of implementation. Public Administration Issues, 1, 98-126.

Gusmão, J. B. de (2013). A construção da noção de qualidade da educação [Construction of the concept of quality of education]. Ensaio: Avaliação de Políticas Públicas Educacionais, 94(236), 299-322.

Gusmão,J. B. de (2010). Qualidade da educação no Brasil: consenso e diversidade de significados [The quality of education in Brazil: consensus and diversity of meanings]. (Master Thesis), Universidade de São Paulo, São Paulo.

Gustafsson, B. A., Shi, L., \& Sicular, T. (2008). Inequality and Public Policy in China. New York, NY: Cambridge University Press.

Haddad, S., \& Di Pierro, M. C. (2000). Escolarização de jovens e adultos [Schooling of youngsters and adults]. Revista Brasileira de Educação, 14, 108-130.

Han, M., \& Yang, X. (2001). Educational assessment in China: Lessons from history and future prospects. Assessment in Education: Principles, Policy \& Practice, 8(1), 5-10.

Harris, J., Zhao, Y., \& Caldwell, B. (2009). Global characteristics of school transformation in China. Asia Pacific Journal of Education, 29(4), 413-426.

Higher School of Economics. (2013, August 2). HSE Is Entering BRICS League of Universities. Retrieved from www.hse.ru/en/news/community/90343147.html

Hong, L. (1991). 我国教育督导制度的历史沿革和现状 [The historical course of development and the current state of the Chinese education supervision system]. 北京师范学院 学报(社会科学版), 4, 6-10.

Horta Neto, J. L. (2007). Um olhar retrospectivo sobre a avaliação externa no Brasil: das primeiras medições em educação até ao SAEB de 2005 [A retrospective look at external evaluation in Brazil: From the first measurements in education until SAEB 2005]. Revista Iberoamericana de Educación, 42(5), 1-13.

Huang, W. (2009). 我国教育督导体制现状、问题与改革路径 [The current state, problems and reform path of the Chinese education supervision system]. 教育发展研究, 12, $16-20$.

Huo, C., \& Gao, H. (2006). The new “Compulsory Education Law” and the balanced development of compulsory education in China. 山西高等学校社会科学学报, 18(12), 37-39.

Ianni, O. (1975). A formação do estado populista na América Latina [The formation of the populist state in Latin America]. Rio de Janeiro: Civilização Brasileira.

The Indian Express (2016, 30 September). BRICS Nations Pledge to Step Up Cooperation in Education Sector. Retrieved from http://indianexpress.com/article/education/ brics-nations-pledge-to-step-up-cooperation-in-education-sector-3058246/

Jin, Y. (2004). “督政”与 “督学” 相结合 - 具有中国特色的我国教育督导制度 [Combination of administrative supervision and educational inspection - the characteristic of educational supervisory work in our country]. 徐州师范大学学报 (哲学社会科学版), $30(2), 120-124$.

Kauko, J., Centeno, V. G., Candido, H. H. D., Shiroma, E., \& Klutas, A. (2016). The emergence of quality assessment in Brazilian basic education. European Educational Research Journal, 15(5), 558-579.

Keukeleire, S., \& Hooijmaaijers, B. (2014). The BRICS and other emerging power alliances and multilateral organizations in the Asia-Pacific and the Global South: Challenges for the European Union and its view on multilateralism. Journal of Common Market Studies, $52(3), 582-599$.

Kipnis, A. (2006). Suzhi: A keyword approach. The China Quarterly, 186, 295-313. 
Klein, R. (2006). Como está a educação no Brasil? O que fazer? [How is education in Brazil? What to do?]. Ensaio: Avaliação de Políticas Públicas Educacionais, 14(51), 139-172.

Laliberté, A., \& Lanteigne, M. (2008). The issue of challenges to the legitimacy of CCP rule. In A. Laliberté \& M. Lanteigne (Eds.), The Chinese Party-State in the 21st Century: Adaptation and the Reinvention of Legitimacy (pp. 1-21). London \& New York, NY: Routledge.

Law (9.394). LEI No 9.394, de 20 de Dezembro de 1996 [Law number 9,394 from 20 December 1996]. Retrieved November 23, from www.planalto.gov.br/ccivil_03/Leis/L9394.htm

Law, W. (2007). Legislation and educational change: The struggle for social justice and quality in China's compulsory schooling. Education and the Law, 19(3-4), 177-199.

Lee, J., Ding, D., \& Song, H. (2008). School supervision and evaluation in China: The Shanghai perspective. Quality Assurance in Education, 16(2), 148-163.

Lee, T. H. (2000). Education in Traditional China: A History. Leiden, Boston, \& Köln: Brill.

Liu, M. (2016). BRICS development: A long way to a powerful economic club and new international organization. The Pacific Review, 29(3), 443-453.

Liu, Y. (2008). 我国基础教育评价改革的反思与展望 [Reflection and prospect of basic education evaluation reform in China]. 中国民族教育, 9, 10-12.

Livschiz, A. (2006). Pre - revolutionary in form, Soviet in content? Wartime educational reforms and the postwar quest for normality. History of Education, 35(4-5), 541-560.

Long, D., \& Long, R. (1999). Education of Teachers in Russia. Westport: Greenwood Press.

Longo, R. M. J. (1996). Gestão da Qualidade: Evolução Histórica, Conceitos Básicos e Aplicação na Educação [Quality Management: Historical Evolution, Basic Concepts and Its Application to Education], Texto para discussão n.397. Paper presented at the Gestão da Qualidade na Educação: Em Busca da Excelência, Centro de Tecnologia de Gestão Educacional, SENAC - SP.

Luckhurst, J. (2013). Building cooperation between the BRICS and leading industrialized states. Latin American Policy, 4(2), 251-268.

Mahoney, J. (2000). Path dependence in historical sociology. Theory and Society, 29, 507-548.

Mayofis, M. (2015). Predvestiia “ottepeli” v sovetskoi schkol'noi politike pozdnestalinskogo vremeni [Portents of the Khrushchev Thaw in the Soviet school policy of the late-Stalin period]. In I. Kukulin, M. Mayofis, \& P. Safronov (Eds.), Ostrova utopii: Pedagogicheskoe i sotsial'noe proektirovanie poslevoennoi shkoly (1940-1980-e) [Islands of Utopia: Pedagogical and the Social Designing of the Post-War School (1940-1980s)] (pp. 35-106). Moscow: Novoe Literaturnoe Obozrenie.

Meade, B., \& Gershberg, A. I. (2008). Making education reform work for the poor: Accountability and decentralization in Latin America. Journal of Education Policy, 23(3), 299-322.

Meisner, M. J. (1999). Mao's China and After: A History of the People's Republic. New York, NY: Free Press.

Minina, E. (2016). "Quality revolution" in post-Soviet education in Russia: From control to assurance? Journal of Education Policy, 31(6), 1-22.

Moreira, J. R. (1956). Os problemas do Ensino Elementar no Brasil [The problems of elementary education in Brazil]. RBEP, 26(64), 48-59.

Nardi, E. L., Schneider, M. P., \& Rios, M. P. G. (2014). Qualidade na educação básica: ações e estratégias dinamizadoras [Quality in basic education: Motivating actions and strategies]. Educação e Realidade, 39(2), 359-390.

Ngok, K. (2007). Chinese education policy in the context of decentralization and marketization: Evolution and implications. Asia Pacific Education Review, 8(1), 142-157.

OECD. (1998). Review of National Policies for Education: Russian Federation. Paris: OECD.

Oliveira, R. P. de, \& Araujo, G. C. de (2005). Qualidade do ensino: uma nova dimensão da luta pelo direito à educação [Educational quality: A new dimension of the struggle for the right to education]. Revista Brasileira de Educação, 28, 5-23.

Oliveira, R. P. de (2007). Da universalização do ensino fundamental ao desafio da qualidade: uma análise histórica [From the universalization of elementary education to the challenge of education: A historical analysis]. Educação \& Sociedade, 28(100), 661-690. 
Oliveira, R. P. de, \& Santana, W. (Eds.). (2010). Educação e federalismo no Brasil: combater as desigualdades, garantir a diversidade [Education and federalism in Brazil: fighting the inequalities, ensure diversity]. Brasília: UNESCO.

O’Sullivan, D., Manson, S. M., Messina, J. P., \& Crawford, T. W. (2006). Space, place, and complexity science. Environmental Planning A, 38(4), 611-617.Pant, H. V. (2013). The BRICS fallacy. The Washington Quarterly, 36(3), 91-105.

Peixoto, A. M. C. (1995). L'influence des idées étrangères sur l'enseignement au Brésil [The influence of foreign ideas on education in Brazil]. Histoire de l'Education, 65(1), 3-26.

Peng, W., Thomas, S. M., Yang, X., \& Li, J. (2006). Developing school evaluation methods to improve the quality of schooling in China: A pilot 'value added' study. Assessment in Education: Principles, Policy \& Practice, 13(2), 135-154.

Phillips,D.(2017,19 July)."People are getting poorer":Hunger and homelessness as Brazil crisis deepens. The Guardian.Retrieved from www.theguardian.com/global-development/2017/ jul/19/people-getting-poorer-hunger-homelessness-brazil-crisis

Piattoeva, N., \& Gurova, G. (2018). Domesticating international assessments in Russia: Historical grievances, national values, scientific rationality and education modernization. In C. Alarcón \& M. Lawn (Eds.), Assessment Cultures: Historical Perspectives (pp. 87-110). Frankfurt am Main: Peter Lang.

Pierson, P. (2000a). Increasing returns, path dependence, and the study of politics. American Political Science Review, 94(2), 251-267.

Pierson, P. (2000b). Not just what, but when: Timing and sequence in political processes. Studies in American Political Development, 14(1), 72-92.

Polyzoi, E., \& Dneprov, E. (2011). A framework for understanding dramatic change: Educational transformation in post-Soviet Russia. International Perspectives on Education and Society, 14, 155-179.

Postiglione, G. A. (2011). Education. In X. Zang (Ed.), Understanding Chinese Society (pp. 80-95). London \& New York, NY: Routledge.

$\mathrm{Pu}, \mathrm{X}$. (2012). Socialisation as a two-way process: Emerging powers and the diffusion of international norms. The Chinese Journal of International Politics, 5, 341-367.

Qi, T. (2011). Moving toward decentralization? Changing education governance in China after 1985. In T. Huang \& A. W. Wiseman (Eds.), International Perspectives on Education and Society Book Series, Vol. 15, The Impact and Transformation of Education (pp. 19-41). Bingley: Emerald Group Publishing Limited.

Robinson, B., \& Yi, W. (2008). The role and status of non-governmental ("daike”) teachers in China's rural education. International Journal of Educational Development, 28(1), 35-54.

Romanelli, O. D. O. (2007 [1978]). História da educação no Brasil (1930/1973) [History of Education in Brazil]. Petrópolis, Brasil: Editora Vozes.

Schwartzman, S., Pinheiro, R., \& Pillay, P. (Eds.). (2015). Higher Education in the BRICS Countries: Investigating the Pact Between Higher Education and Society. London \& New York, NY: Springer.

Seregny, S. J. (1993). Teachers, politics and the peasant community in Russia, 1895-1918. In School and Society in Tsarist and Soviet Russia (pp. 121-148). London: Palgrave Macmillan.

Sobreira, R., \& Campos, B. C. (2008). Investimento público em educação fundamental e a qualidade do ensino: uma avaliação regional dos resultados do Fundef [Public investment in elementary education and the quality of education: A regional evaluation fo Fundef results] Revista de Administração Pública (RAP), 42(2), 327-246.

Souza, A. M., \& Costa, M. A. (2009). Reformas do ensino básico: tendências e limites [Basic education reforms: Trends and limits]. Ensaio: Avaliação e Políticas Públicas em Educação, 17(64), 477-494.

Souza, C. (2002). Brazil: The prospects of a center-constraining federation in a fragmented polity. Publius, 32(2), 23-48. 
Startsev, B. (2012). Khroniki obrazovatelnoi politiki: 1991-2011 [Chronicles of Educational Policy: 1991-2011]. Moscow: Izdatel'skii dom Vysshei shkoly ekonomiki.

Stuenkel, O. (2014). Emerging powers and status: The case of the first BRICs summit. Asian Perspective, 38, 89-109.

Teets, J. C. (2013). Let many civil societies bloom: The rise of consultative authoritarianism in China. The China Quarterly, 213, 19-38. Tret'iakov, P. (1997). Upravlenie shkoloi po rezul'tatam. Praktika pedagogicheskogo menedzhmenta. [Managing school by results. The practice of pedagogical management]. Moscow: Novaia shkola.

Ünay, S. (2013). Reality or mirage? BRICS and the making of multipolarity in the global political economy. Insight Turkey, 15(3), 77-94.

Vianna, H. M. (1990). Avaliação do rendimento de alunos de escolas de 1.0 grau da rede pública: um estudo em 15 capitais e 24 cidades [Performence Evaluation of 1st Grade Pupils in Public Schools: A Study in 15 Capitals and 24 Cities]. São Paulo: Fundação Carlos Chagas.

Wang, X. (2003). Education in China Since 1976. London: McFarland \& Company.

Wang, Z., \& Zhang, L. (2009). 我国基础教育课程监控机制的构建 - 基于历史分析的视角 [The construction of the Chinese basic education curriculum monitoring mechanism - a historical analysis perspective]. 现代教育管, 8, 61-63.

West, R., \& Crighton, J. (1999). Examination reform in central and Eastern Europe: Issues and trends. Assessment in Education, 6(2), 271-289.

Wirth, J. D. (1997). Reviewed work: The means of our salvation: Public education in Brazil, 1930-1995 by David N. Plank. American Journal of Education, 105(4), 484-488.

World Bank. (1995). Russia: Education in the Transition. Washington, DC: World Bank Publications.

World Bank. (1999). Reforming Education in the Regions of Russia. Washington, DC: World Bank Publications.

World Bank. (2001). Russia - Education Reform Project. Washington, DC: World Bank Publications.

Wu, J., \& Dai, J. (2013). 我国课程监控制度探析 [Probing into the curriculum monitoring system of China]. 教育理论与实践 Theory and Practice of Education, 4, 53-56.

Wu, X. (2012). School choice with Chinese characteristics. Comparative Education, 48(3), $347-366$.

Xin, T., \& Kang, C. (2012). Qualitative advances of China's basic education since reform and opening up: A brief overview. Chinese Education and Society, 45(1), 42-50.

Xinhua. (2016, 30 September). 4th BRICS Education Summit held in New Delhi. Retrieved from http://news.xinhuanet.com/english/2016-09/30/c_135726098.htm

Xu, F., \& Li, H. (2011). 基础教育质量标准及评价体系探讨 [An investigation into the system of basic education quality standards and assessment]. 教育与教学研究, 3, 48-50.

Yang, J. (2001). 20年来我国教育督导理论与实践的新探索 [Twenty years of theory and practice in education inspection in China: An exploration]. 西北师大学报(社会科学版), 38(2), 36-42.

Yang, Y., \& Guo, L. (2005). 督政与督学相结合 - 中国教育督导制度的显著特色 [Combination of administrative supervision and educational inspection]. 教育科学, 21(2), 37-40.

Zhang, Z. (2010). 中国基础教育监测的实践与思考 [The practice and exploration of basic education monitoring in China]. 基础教育, 7(7), 3-7.

Zhou, J., \& Reed, L. (2005). Chinese government documents on teacher education since the 1980s. Journal of Education for Teaching, 31(3), 201-213.

Zhou, S. (2012). 国内外基础教育质量监测概览 [An overview of basic education quality monitoring at home and abroad]. 江苏教育研究, 6, 58-63.

Zhu, Y. (2011). "Performance Legitimacy" and China's political adaptation strategy. Journal of Chinese Political Science, 16(2), 123-140. 


\title{
4 Established and emerging actors in the national political arenas
}

\author{
Jaakko Kauko, Olli Suominen, Vera Gorodski \\ Centeno, Nelli Piattoeva, and Tuomas Takala
}

\section{Introduction}

Our book's key questions concern how agendas and actors' arenas interact. In analysing the policy process, Baumgartner and Jones observe that political change happens in ruptures after the agenda is changed by growing positive, change-supporting feedback, such as diffusion from other political systems, which catalyses change in the political sub-system's arrangement (Baumgartner \& Jones 2009). An analysis of this in relation to quality assurance and evaluation (QAE) is of interest to our research.

We can identify a transnational QAE agenda. As we pointed out in Chapter 1, instead of looking at all the contents of this QAE "megatrend" (Vedung 2003: p. 1), we focus on how the integration of global education policy discourses and practices and the general interest in measuring quality in education have changed and reshaped the actor relations within a polity. For example, there is evidence of the effects of QAE on the roles of national education policy actors in how information and data have provided the means for an attempt to regain central power (Ozga et al. 2011) while simultaneously, and somewhat paradoxically, creating an image of a more decentralised, horizontal, and networked understanding of knowledge (Ozga 2012). To reiterate Chapter 1's idea, it is only when a slippery and undefinable notion of quality is applied that the QAE agenda starts to affect the national political arena. For example, new organisations responsible for large-scale assessments are introduced, leading to a rearranging of the existing organisations' roles.

When a rupture of the status quo happens, "[t]he old policymaking institutions find themselves replaced or in competition with new bodies that favor different policy proposals" (Baumgartner \& Jones 2009: p. 4). Central to the understanding of these dynamics is the analysis of sub-systems such as the education system and the possible QAE expert communities which exist within it. Baumgartner and Jones discuss "policy monopolies" which have an institutional structure connected to policymaking and exclusive access to expertise and which legitimise their action with the help of core political values such as fairness or economic growth. These monopolies can be disturbed, for example, with the help of agenda-setting through the media, whereas apathy helps 
to sustain a monopoly (Baumgartner \& Jones 2009). We assume that QAE expert communities meet this definition. QAE policy meets this characterisation in terms of exclusion through expertise and the core political values of enhancing learning and economic growth. In our research, we are interested in understanding the extent to which the potential positive, change-supporting feedback on the agendas of these three countries has resulted in a change in polity.

Using the CADEP terminology adopted in Chapter 1, this chapter starts an analysis of the political constellations of actor, that is, the political situation. We demonstrate that the political constellation of actors is inseparable from changes in the second dimension of CADEP, namely the political possibilities. In attempting to understand the relationship between these two dimensions, we use the idea of Baumgartner and Jones (2009), who claim that policy agendas and the structure of the political system are interconnected. Distinguishing the relevant actors is also connected with the idea of what is on the agenda. Our primary focus is on structural change, but we also link this to the changing QAE agenda. We aim to analyse the changing national political situation in Brazil, China, and Russia in relation to the possibilities and restrictions created by the effort to measure and improve the quality of school education.

Using the data presented in Chapter 2, this chapter focuses on documentary and interview data from individual actors - the international and key national organisations involved in QAE policy and practice in the three countries. We focus on interviews at international and national levels. These interviews and documents largely sourced online limit our empirical interest to developments since the turn of the millennium.

Although all three countries have a history of suspicion to various degrees towards international actors, since at least the 1990s, they have become increasingly involved in international cooperation in the field of education quality and its evaluation, which means that many actor relations and agendas are also transnationally linked. To understand the changing constellations of actors in QAE policy, our analysis focuses on two dynamics. The first relates to how the development of expert communities is networked transnationally to international actors, the second to how the changing polity has activated other actors.

\section{Building national QAE education policy communities}

The development of QAE capacity and tools in Brazil, China, and Russia is also connected to external advice from international organisations. However, the timing and extension has varied in each case. In line with our theory, the technical side of large-scale assessment is a reflection of actor relations. As we pointed out in the book's introduction, the question of handling, designing, and planning data use is political, and it therefore makes sense for national governments to develop their capacity. Where the interconnectedness of agendas with actor relations is concerned, we observe that agendas slowly began to adopt QAE ideas in the 1990s and that its feedback resulted in different degrees 
of polity reorganisation. In each context, the development of national expert communities is tightly linked to financial resources and political decisions.

\section{The changing agenda in the $1990 \mathrm{~s}$}

During the 1990s, in all countries, the international and transnational influences of QAE began to make an impact. The international community affected this in two ways: through direct recommendations from international organisations, especially the World Bank, and through the influence of the internationally networked expert community. In each context, the mix varied.

In Brazil, there was a gradual accumulation of national expert networks and their capacity in parallel with international organisations' involvement. Brazil differs from Russia and China in its longer-term cooperation with the Organisation of American States, the US American Aid Institution (USAID), the United Nations Educational, Scientific and Cultural Organisation (UNESCO), and the World Bank, among others, which has been a reality since World War II. A research article from our project concluded:

Education-indicator programmes have blossomed since the 1990s, alongside global education-related IO [international organisation] programmes. Independently of their political position, all the post-dictatorship governments took steps towards implementing assessment with a view to improving quality in education, a strategy that mirrored global developments. In this development, we have pointed out the importance of the long buildup of QAE capacity and webs of experts.

(Kauko et al. 2016)

China's engagement with the international community began in earnest only in the post-Mao period, and it was not until the 1980s that China joined the entire network of intergovernmental organisations (IGOs) (Kent 2002; Ngok \& Kwong 2003). By the 1990s, China's policy of opening to the world had increasingly exposed the Chinese education community to new foreign ideas, and international education issues had noticeably surfaced. Journals increasingly dealt with the subject, and the first government research units were established (Altbach 1991). Various IGOs, such as UNESCO, through its global Education for All movement, the World Bank, the OECD, and the European Union also became increasingly active in promoting transnational education practices and programmes in China (Ngok \& Kwong 2003; Suominen et al. 2017). By the mid-1990s, many international non-governmental organisations (INGOs) had also begun to launch projects and establish offices in the country (Ma 2002; Deng 2010; Yang G. 2005).

As Chapter 3 described, simultaneously, and partly resulting from these international contacts, the Chinese education system had also begun to shift from quantitative to qualitative targets to boost the state's modernisation drive. Many reformers who advocated these ideas, later known in the Chinese 
discourse as "quality education", were familiar with Western education theory, and the North American notion of "competency-based education", emphasising specific competencies instead of exam success, was especially popular (Kipnis 2006).

This shift in priorities also required the development of a national QAE capacity. International experience and practice were especially influential in the construction of the national assessment system (Zhang \& Wan 2017). An interviewee explained, "As a matter of fact, it [the establishment of the assessment system] is also a reply to the demands of globalisation. So, against a backdrop like this, we also wanted to understand what the current situation of Chinese education was like" (CN-E-02). The OECD's Programme for International Student Assessment (PISA) surveys' strong influence on the development of this national assessment system is acknowledged by practitioners and academics alike (the assessment has even been called the "Chinese PISA" - a formulation used by many of our interviewees), although direct borrowing has occurred mainly in technical areas.

In post-Soviet Russia, international organisations gained some prominence between the mid-1990s and mid-2000s. In this period's early years, in a bilateral Dutch-Russian project, the World Bank and the OECD prepared reports on Russian education. These reports were diplomatic enough to give credit to the achievements of the Russian education system during the Soviet period, but the basic message was one of strong criticism of the traditional Russian notion of what constituted quality education (Leonteva, Plomp, \& Voogt 1998; World Bank 1995; OECD 1998). This pedagogical tradition was criticised as unsuitable for the needs of a market economy, and a new system of assessment was recommended as a tool for changing the mode of learning, examinations, incentivisation, and information gathering. As evidence for this argument, reference was made to the low performance of Russian students in PISA, in sharp contrast with their excellent performance in the Trends in International Mathematics and Science Study (TIMSS) and Progress in International Reading Literacy Study (PIRLS) tests. However, these recommendations resonated with the views of a reform-minded faction of Russian policymakers and education experts, and it is impossible to demonstrate a causal effect between the two. Yet very few QAE reforms took off at the national level during this period, apart from the piloting of the national school-leaving examination.

In the late 1990s and early 2000s, most changes in Russia were first implemented at the sub-national level, channelled through World Bank-funded project work in selected pilot regions. During this period, many assessment consultants travelled to Russia to promote their views on appropriate policy and practice, typically with very little knowledge and understanding of the existing baseline situation. Our interviews indicate that Russian experts considered much of the advice patronising and inflexible. Nevertheless, after this troubled start, gradual processes of dialogue followed. In the Republic of Chuvashia, where we conducted our fieldwork, the World Bank-funded project (operational between 2002 and 2006) was generally regarded by our interviewees as having produced lasting results in capacity building, and the same is 
acknowledged of the bank's Project Completion Report (World Bank 2007). One of our interviewees, who has held a prominent administrative position, described this process as follows:

Everything was new for us, so our views did not mean much, while they [the international experts] had seen a lot, and there were a lot of compromises in the discussion and defence phases [of the proposed projects] ... Sometimes it [discussion on the intermediary reports] got really crazy. Either the experts or our people would cry because of the misunderstandings or tough approach to a position if you couldn't prove it, even if you were absolutely convinced you were right. So, they were very rigorous discussions, very deep ones.

(RU-E-15)

This aptly describes the general influence in all cases: data expertise is an appealing argument for national steering and guidance. Each of the countries' expert networks were engaged in dialogue.

The agenda in each country therefore evolved during the 1990s to support the idea of QAE in education governance. This began to bear fruit in conjunction with the changing financial and political situation during the new millennium and eventually affected the political constellation of actors.

\section{Building capacity}

The extent to which Brazil, China, and Russia have worked with international organisations varies, and the nature of cooperation seems to depend on their respective financial and political situations.

At the turn of the twenty-first century the World Bank became more active in Brazil (Kauko et al. 2016). However, its focus has shifted, as none of the twenty-five projects between 2003 and 2016 operated on the national level (World Bank 2016). Indeed, the Brazilian interviewees described how international organisations had redirected their activity towards sub-national actors, because the national level had developed capacity and funding independence and had different political motives. A new QAE policy expertise started to take shape with the help of independent analysis, greater independence in funding, and increased political independence, which eventually changed polity.

Brazil appears to have attained a national capacity for independent data analysis in the 2000s, meaning that international organisations' technical assistance was no longer needed. Indeed, Brazilian governments had implemented largescale assessments in the 1990s. Interviewees from different branches of an international organisation discussed this shift to working with sub-national instead of national actors:

We haven't had the dialogue at the federal level that we would like in the past five or six years, but we've been very active at the state level.

(BR-IGO-01) 
Here in Brazil, fifteen years ago, we were doing education projects at the federal level ... We don't do that any longer. They don't need us.

(BR-IGO-02)

Besides the development of national capacity, the international loaning organisations, the World Bank and the Inter-American Development Bank (BID), pointed to funding independence at the federal level as one of the main reasons for the change of focus to the sub-national level. Indeed, whereas some interviewees pointed to the strong national capacity emanating from the National Institute for Educational Studies and Research (INEP: the office responsible for large-scale assessments), the international organisations did not trust the implementation capacity of all the Brazilian states. Unlike the federal government, they felt financially strapped states and municipal level governments especially needed both financial and technical advice.

In terms of financing the federal level doesn't need [name of an international organisation]'s financing. This is different from twenty or twentyfive years ago. The state and municipal levels still need financing.

(BR-IGO-02)

Basically, one of my first impressions when I came to the [IGO] was that obviously you want to help the poorest states.

(BR-IGO-06)

The need and potential for political independence at the federal level seems also to have been behind the international organisations' new sub-national activity. A Ministry of Education representative pointed out that international organisations like the OECD and the World Bank struggled to understand Brazil's complexity, making them less attractive partners.

I would love to work with anyone who can understand that we are very diverse and there is no magic solution for anything ... If the World Bank or the OECD could understand this I would be happy to work with them ... If the World Bank wants to do this, I'm a partner.

(BR-N-10)

A representative of an international organisation noted that ministers were perhaps unhappy with some of the results of their reports.

I'm not sure, but maybe the last ministers did not agree with the evidence that the [international organisation] supports. Maybe.

(BR-IGO-03)

This political stance is further visible in the different emphases of international organisation and Ministry of Education interviewees concerning whom the states should consult in their technical work. The former emphasised 
international organisations' technical expertise, whereas the latter saw universities as suitable partners.

I think that sometimes one of the things that [international organisation] is doing is helping some of the states, as we have done in Rio, to strengthen the statistical and planning units within the secretariats so they can be more effective.

(BR-IGO-06)

We have to evolve to a model of more partnership so the universities play the most important role, and the states and cities of course don't have many technical people to work with us: we have to make an effort to understand why they need something, and the university can provide these services better than they can.

(BR-N-10)

The changes in the Brazilian political arena indicate the gradual accumulation of national QAE policy expertise and the way in which this has sidelined international organisations at the national level. Financial capacity and the potential for using knowledge are essential in the quest to become a relevant actor in the Brazilian system. The interviewees describe how the national government's dependence on international expertise diminished after it had succeeded in developing financial and technical QAE resources. In Brazil, QAE thus appears to be related not only to technical and financial but also to political independence.

In China, the development of expertise is advanced, but there is also some caution concerning outside political influence. The events of 1989 proved a turning point, after which China became more reserved about foreign education patterns (Altbach 1991). China remains ambivalent about international cooperation because it is seen as presenting a potential threat to the party-state's sovereignty (Kent 2002). Although education issues are not especially sensitive in China, in recent years, the government has become especially cautious about INGOs operating in China (Yin 2009; Hsia \& White III 2002). As Yin (2009: p. 534) argues, "While recognizing the potential contributions of foreign NGOs, the Chinese government is also becoming increasingly wary of the growing presence of foreign NGOs in the country and has warned against the 'potential national threat' that they may pose." Our interviewees also confirmed this increasing suspicion, although they did not elaborate why this had been the case either with their organisations or the education field in general. Using Baumgartner and Jones's concepts, it is clear Chinese policy seeks to maintain apathy regarding assessments.

Of course, none of this is to say that internationally focused work has had no impact on China. First, the country has been influenced by personal experiences and contacts. The assessment system especially, as has been mentioned, is largely staffed by people familiar with foreign practice who have been involved in extensive exchanges of ideas. For example, there has been cooperation at workshops, lectures, and consultations with people working with the OECD's 
Teaching and Learning International Survey (TALIS), the Educational Testing Service, and the International Association for the Evaluation of Educational Achievement. Foreign scholars also increasingly travel to China as guest speakers and visiting scholars.

Second, there have also been more direct contacts. IGOs are directly consulted, for example, when national education reform plans are drafted to assist in their incorporation into China's international commitments. UN agencies seem especially to be in a position in which they are seen - as one interviewee (CN-IGO-01) put it - as more "governmental" and are thus consulted at an even earlier stage of policy formulation than previously. Most recently, the OECD, with the World Bank and other IGOs, participated in the preparation of the National Guidelines for Medium- and Long-Term Educational Reform and Development, which outlines the future development of education for 2010 until 2020 (Gu 2010). Our interviews confirmed this also applies to the next development plan, which extends to 2030 and is under construction. However, because the Chinese government has had a quite straightforward vision of what counts as quality in education, IGOs' consultative role is primarily to plug the gaps beyond the room for state action which the national QAE systems do not cover. In implementing their own programmes, IGOs need to align their goals to meet the goals of national reform programmes. In addition to IGOs, both semi-governmental and non-governmental international development aid organisations (we refer to all these actors as INGOs) have been active in China. The Chinese state does not allow INGOs to operate independently. They are required to work with local state education bureaus. Moreover, except in cases where support is limited to the provision of funding, INGOs can only operate on sub-national levels, that is, with provincial, county, city, or school-level actors, and they align their development goals and plans with national plans. The role of INGOs has also been restricted to ensure quality beyond the room for state action - much as is the case with IGOs but to an even greater extent and INGOs have thus focused on issues such as sex education and education for disabled children. These notions of quality beyond the room of the state are also reflected in the data used to ensure quality (CN-IGO-01).

IGO representatives, however, fully acknowledge that they lack the state's capacity in data gathering:

I think, of course, we may not do [as] well ... as [state] research institutes in terms of building the evidence. That's where we have to learn.

(CN-IGO-04)

The nature of international experts' roles and communication with them has changed in Russia. No large international organisation currently holds a visible position in Russia, and the World Bank no longer contributes to Russian education reforms. Much as in China, it could also be said that testing as one element of QAE has been more influenced by cooperation with specialised agencies (e.g., ETS, CITO, or Cambridge Assessment) and individual experts 
than by any large-scale, externally funded education reform. However, cooperation still occurs in the context of the transnational QAE agenda outlined in Chapter 1. Russian experts and civil servants participate in various international activities at their own initiative. Currently, cooperation with international actors seems to happen mostly around the international learning tests (PISA, PIRLS, and TIMSS), as the Russian experts who administer and analyse these data have become members of executive boards or subject committees and/or participate in international conferences and meetings of assessment specialists and researchers. However, these tests are not understood as changing the system in a top-down manner:

Interviewer (I): So, the reorientation took place under the influence of participation in international assessment. Or is participation in these assessments the result?

Respondent $(R)$ : Reorientation did not happen for this reason; it took place because schools in our country started to change ... We can't say the Russian school started to teach children to apply knowledge because of international surveys. No, that would be a complete lie. The truth is that schools started to change. We ourselves understood what was important, that children should not learn by heart, and need to apply what they learn more. Because our economy is changing, it is becoming integrated into the world and so on. And only on this basis do we take part in surveys which compare us on the basis of criteria we understand (RU-E-12).

In all three contexts, the transnational agenda for the production of data has affected the national polity. In Brazil, increasing capacity has resulted in less dependency on data and resources provided by international organisations. In China, international organisations never gained a strong position in the provision of data or resources but were instead confined to indirectly influencing decision-makers and focusing more directly on issues deemed marginal in the drive for education reform. In Russia, international organisations' role is less than it was in the mid-2000s. The change in QAE agendas has therefore led to the development of national QAE expert communities which rebalance state actors' roles (this redefinition of state and expertise is analysed more thoroughly in Chapter 5). In this process, national governments have enhanced their data analysis capacity to meet the level of international organisations. At the same time, data experts have gained more autonomy. Nevertheless, international organisations have been increasingly sidelined as national capacity has grown.

\section{New actors}

In the previous section, we described how QAE actor constellations were redefined following a change in national agendas. This has affected polity, as it has 
changed the role of other actors in each of the countries. All have witnessed the growing importance of organisations responsible for large-scale assessments, which we address in more detail in Chapter 5 . There are also varying degrees to which the different actors - sub-national governments, international and intergovernmental organisations, and national and local non-governmental actors (non-profit organisations, commercial companies, professional networks) - find room for action with the help of claims for data expertise.

Our analysis shows that the intertwining of changing agendas and actor constellations is visible in how QAE expertise and capacity are essential to justify who may belong to the expert community. This is true of all our case countries, even though they have quite different governance structures. In Brazil, China, and Russia, new expert agencies responsible for conducting large-scale assessments have been established. It is also of interest that we can observe other emerging actors such as third-sector movements (Brazil), think tanks (China), and fluid expert networks (Russia), reshaping the education-political landscape. However, these attempts of unofficial non-governmental or semi-governmental (China) organisations to gain greater prominence in decision-making with the help of QAE expertise do not always succeed.

\section{Brazil: ascendancy of civic movements}

NGOs in Brazil are well networked with both public and private actors at the national and international levels: they occupy a firm position as part of the QAE policy actor constellation. QAE policy and practice have shaped and fed their agendas, which are closely related to government QAE policy and practice.

Social movement organisations, such as Campanha Nacional pelo direito à Educação (Campanha: the Brazilian Campaign for the Right to Education) and Todos pela Educação (TPE: All for Education), function as major platforms and have a decisive impact on policymaking (see Centeno, Kauko, \& Candido 2017). These NGOs bring together almost every actor, national and international, and public and private, and therefore possess significant legitimacy. Furthermore, they both exert their influence by lobbying government and producing studies, proposals, and activities, as well as by networking and cooperating with major national public actors like the INEP and the Ministry of Education and international and national organisations.

QAE has paved the way, either triggering or making possible their involvement and positioning in the education arena, both in terms of knowledge production and policymaking. As one interviewee explains:

[T] here are several social actors which had faded a little [from the development of QAE] and [others] which were not organised [but] which emerged with that movement [of large-scale assessment], particularly Todos pela Educação which was the social framework of legitimisation for the Haddad [Minister of Education] project [of the large-scale assessment indicator, IDEB.] A Campanha ... which is the bigger [social] movement ... didn't 
have [large-scale] evaluation on its agenda at that time ... [It has] taken [it] a long time to construct that vision of the SINAEB, ... the [recently proposed] National Evaluation System of Basic Education which was a painful process [for Campanha] ... with a big effort of [Campanha] ... but Todos pela Educação emerged within that framework of [large-scale] evaluation.

(BR-NNGO-04)

Privately funded foundations are part of the new but vibrant Brazilian civil society. They are important elements of QAE networks. Besides exerting their influence through Campanha and TPE, they also have a voice of their own and occupy an important place in the political arena. Nationally, they influence agenda- setting through knowledge production, vigorous networking, and media influence:

[An] important group that has organised itself recently are the foundations of major corporate groups ... They are groups based on a vision of demanding results. They have organised themselves to say "Look, we have to have the children finishing elementary education." ... This group has grown ... It plays an important role and is very present in the media.

(BR-N-03)

At the sub-national level, privately funded foundations influence local government projects through their technical and financial capacity. These foundations can gather various domestic and foreign sponsors and IGO funding under national projects channelled to schools and individuals, the details of which are published on their websites. IGOs acknowledge the foundations' strength and engage actively with them:

And in Brazil most of the research I'm doing is with foundations like the Lemann Foundation and the Instituto Unibanco in São Paulo. The Ayrton Senna Foundation too. I mean, there are some which have really good people who know education and provide a lot of technical help to the states and municipalities.

(BR-IGO-05)

A need for quality expertise was the catalyst in the establishment of the Brazilian Association of Educational Evaluation (ABAVE). The scholars involved found it difficult to access the main academic forums and were constantly struggling to convey the importance and meaning of the quantitative approach and its tools. Founded in 2003, the association has gained enormous influence on QAE policy and practice:

[In Brazil] we had the National Association of [Graduate Studies and] Research in Education [now the ANPEd]. At some stage that Association split because a group of scholars [who were at the genesis of the 
large-scale assessments] could not find a way to engage in dialogue within an association of education researchers with a broad focus on the Faculties of Education ... which are resistant to this framework. So, the spilt was a demonstration, and today ABAVE ... is one of the organisations with which ... [the INEP] dialogue[s] a lot.

(BR-N-01)

In Brazil, the QAE actor constellation has consisted not only of state actors but also third-sector organisations and movements. Indeed, the QAE agenda in Brazil has stimulated actors' traditional roles and resulted in the heavy involvement of the third sector and business interests.

\section{China: "scholars doing scholars' work"?}

The creation of the national QAE system in China has given room for action to existing actors and given rise to new ones. First, the construction of the assessment system has transferred power to sub-national education bureaus in relation to their corresponding financial bureaus. Under the communist party-state system, education, like other politicised spheres, is based on long-term planning, and it is the ministerial staff who are tasked with policymaking. High-ranking officers in the ministries have had much say in how things are done. However, although policies are decided at national and provincial levels, where funding and policy implementation are concerned, the regions themselves have considerably more responsibility (Postiglione 2011; Qi 2011). Many of our interviewees identified a trend towards such policymaking decentralisation. More important, this was also the case where monitoring and assessing quality in education were concerned:

[W] hen it comes to basic education [i.e., the nine-year compulsory education system] quality monitoring in China, we have come up with a saying: "make counties the system of basic education quality assurance". This means that wherever you go, the county level carries out basic education quality management and control. Province and national level governments will formulate macro-level supervision policies, but the concrete executive units are the counties.

(CN-E-13)

As national assessments have started providing feedback to the localities, the local educational bureaus, as one interviewee pointed out, have used it as evidence when they have confronted the financial departments at corresponding levels and demanded resources to tackle the problems they have identified.

Second, and perhaps more important, a notable change in actor relations has come with the emergence of actors which are considerably more independent of the party-state's control than previously. In QAE policymaking, these developments have manifested themselves in two ways. As has been mentioned, 
both IGOs and INGOs are consulted in the policymaking process, especially when the government is addressing what it considers more marginal issues in its reforms plans. In addition to direct consultation, the staff working for these organisations suggested when interviewed that it is hoped that decision-makers themselves will learn from their initiatives. The logic is that policymakers either observe from a distance how projects are faring or that the localities themselves or the media pass the information upwards. The INGOs also seek to engage directly with staff from domestic NGOs, as well as practitioners and academics from the government system whom they perceive as influential. Despite this, the organisations' personnel acknowledge that their influence on policy is somewhat limited, except perhaps where changes in practice in the localities in which they are directly working with education issues are concerned.

However, the construction of the national QAE system has made data experts more politically relevant. First, provincial institutes of education research have been established. These researchers are tasked with researching education issues and submit their work to the corresponding executive departments to assist in policymaking. Second, the Ministry of Education has established "national bases" in universities; these are essentially think tanks tasked with, as one interviewee (CN-E-05) put it, the "study of policy and study for policy". The staff working at these bases are academics, and many naturally have extensive international experience. Because of the traditional emphasis on ranking, much attention has been paid to the OECD's PISA rankings, and the different nations' PISA success propels research interest towards certain education regimes. These universities have also established designated branches to research international organisations which have strengthened their links with IGOs like the World Bank, UNESCO, and the OECD. However, it is noteworthy that the Ministry of Education's bureaucracy does not explicitly bias research foci towards certain national systems or research topics. Institutes of education research and university-based think tanks produce research data on international organisations and assessment practices, which are then utilised to assist in decision-making when policies are formulated. A member (CN-E-07) of such a think tank explained, "As a matter of fact our unit is a think tank of the state's Ministry of Education. That means that every time they introduce a policy, we need to do research." Although these expert institutions cannot operate entirely independently of the party-state, their staff consists of academics rather than bureaucrats or party functionaries. This emergence of a semi-state approach represents a major departure from the days when the Ministry of Education was in absolute control: "Many people in the Ministry of Education now say that scholars should do scholars' work, administrators should do administrators' work" (CN-E-02). However, despite ambition to change the situation, the influence of scholars on policy is still somewhat marginal. One interviewee complained,

[W]hen formulating Chinese national policies and school policies, the whole process from formulation to implementation is closed. In recent years it has become more open, but despite this, many scholars' viewpoints 
hardly ever become policy in practice. The state is vigorously pushing forward this aspect [of including scholars' perspectives].

(CN-E-13)

Indeed, the model of policymaking involving prominent individuals within the ministry is still dominant, and policymakers rarely have the inclination or time to engage deeply with academics and experts. Consequently, communication between the groups is often limited to very short policy recommendation briefings.

All in all, and much in line with the technocratic tendencies at play in wider Chinese society, normative power has been transferred from party-state functionaries to academics, whose professional networks and research foci position them firmly within a transnational network. As our analytical framework suggests, this reveals the changes QAE has made to the actor constellation: where the question of who participates in defining and assessing quality is concerned, emerging actors are challenging the existing status quo. An interviewee draws an interesting parallel with Chinese education reforms, in which relevance also equates to financial gain:

These things [reforms of the QAE system] benefit certain people. Actually, it is not just education, but in other aspects the deep reforms in China touch certain interests. But these reforms have to be made and there is no other option. If not, there is no development ... If we take the reform of China's state-owned enterprises as an example, they were all monopolies before. Communications and petroleum [industries], for example, were all monopolies. And monopolies do not have competition, and without competition the results will always be very poor. If the state's inputs were very big, it was possible that the profits were also very high, but all these profits were made by monopolies. So, these state-owned enterprises were reformed by dragging them into a system of competition. But this of course did not go well with some people, because previously they were able to make a lot of money, and this changed when private enterprises came into the picture. Other people took their slice of the cake. This is also the case with education.

(CN-S-01)

Such an approach indicates, implicitly at least, that relevance is not - and should not be - only a top-down decision, but different actors' perception of quality (and how it should be assessed) should compete for relevance in the QAE field.

\section{Russia: state-dependent $\mathrm{Q} A E$}

Compared with Brazil, Russian QAE reforms and agenda-setting are more state-driven and in this sense closer to the Chinese constellation. Where the agenda is concerned, the recent change in Russia has been significant. Previously, 
Russia only had one standardised test at the end of grade 11 (the Unified State Exam, USE), which became compulsory throughout the country in 2009. The USE is both a school graduation and university entrance examination. Alongside more general education statistics, the scores of the USE have constituted a key source of information for national system evaluation and evidence-based policymaking. The Russian federal authorities are now seeking to reinstate a "uniform educational space" for education. This entails the introduction of new federal curricular guidelines which define the expected learning results and development of more diverse QAE procedures initiated by the national authorities.

The federal level has introduced another standardised graduation examination after grade 9 (at the end of lower secondary, or basic, education). A samplebased National Study of Education Quality (NIKO) was also initiated in 2014 with a focus on primary and secondary school subjects and their respective skills. It was introduced with the intention of grasping how children are taught in different parts of the country to identify problematic areas and best practices and to compile nationwide education statistics. The federal authorities particularly emphasise the difference between NIKO and the high-stakes USE, maintaining that the former poses no risk to the students and schools assessed in the survey. Since 2015, the federal level has also started to administer the All-Russia Examinations, now being piloted and planned as part of the overall evaluation system in the near future. They test end-of-school-year learning results annually, and these are said to provide information on learning achievements for school, local, and federal actors.

These different data sources form the basis of a large annual report about the state of the education system, prepared by a department of the federal ministry. The first such report was published in 2015 and based on information collected in 2014:

Well, this is a bit of an analogy to what in some countries is called a national report on the system of education. We had nothing like that [for about 10 years]. We only collected statistics in one way or another, and they were utilised locally somewhere for developing some local projects. But from last year [2015] it became a systematic process, and we write a serious report about all levels of education on the basis of statistical data, data we receive from the federal units on the basis of a particular plan of the characteristics of the system. It is not only a statistical database, but also an analytical database that detects some trends, some problematic areas, and some serious changes affected by the decisions taken earlier.

(RU-N-03)

It is clear from our interview materials that it is planned to make the collection of data about the education system more detailed and systematic, which will have further effects on the actor constellation. When our interviews were conducted, the federal ministry was in the process of establishing a blueprint for how 
the different sources of information would feed into national decision-making. Indeed, the federal government is the main architect in designing changes to the QAE organisations. The recently established Federal Institute of Education Quality Evaluation is intended to become a centre for data accumulation and processing under the auspices of the Federal Service for Supervision in Education and Science, which means the Federal Ministry of Education and Science is its superior. Moreover, the federal level is dissatisfied with the quality of information it receives and is seeking to establish a system that will help obtain more detailed knowledge of schools:

[T]he subjects of the Russian Federation are in charge of collecting schoollevel data, so that it is aggregated on the level of the federal subjects and presented this way to the ministry. So, this means that we don't see the construction inside the school. This is the first problem and we are aware of it, so from January we will introduce a system that will enable us to establish an infrastructure for, from next autumn and winter, gaining information about each school.

(RU-N-03)

The developments just described signal a strong desire for a nationally anchored centralised and standardised education evaluation system. This entails increasingly centralised data collection and analysis by actors accountable to and financed by the national authorities. At the same time, expert networks also play an important role in Russia. The predecessors of the USE and the structures administering them were small-scale commercial organisations and research groups interested in standardised testing. They learned the craft of standardised testing from available international sources because of their personal or commercial interest, aided by their prior training in mathematics and psychology, for example. The historical roots of the two ministerial units now running the USE for grades 11 and 9 are in the early post-Soviet practice of voluntary standardised testing of university applicants. These skills and wider experience were utilised when standardised assessments became a federal initiative, promoting experts with the required skills to the higher ranks of the newly established federal structures.

An equally important and partly connected group of evaluation experts began developing their evaluation proficiency in direct connection with the international tests in which Russia had first participated - TIMSS in 1995 and PISA and PIRLS in the early 2000s. These experts later performed important roles as test developers and analysts in the USE. However, as the following quotations demonstrate, they did not take the transfer of foreign expertise for granted, and they quickly developed their own capacity:

Then we started, ... this is the very first point [to consider], ... what can and cannot be transferred. We learned ... how to do it - we even invited specialists from the Netherlands who developed PISA 2003. They held a 
wonderful seminar. Almost all the subject specialists who write test items for the USE took part in the seminar. It was great, interesting, but we could not utilise the test tasks themselves.

(RU-E-12)

We knew the state of affairs in Russia. Unfortunately, there were situations when our colleagues, especially Americans, thought that we had just jumped off a branch of a tree ... Nevertheless, of course, we learned something, and what we told them about what we have done was interesting for them too.

(RU-E-10)

Overall, links between national and international experts are highly appreciated, which also means that policy transfer has occurred through professional interactions the Russian actors for the most part perceive as normal mutual learning and professional communication. Testing expertise has been the most significant lesson:

You understand, the instrument is very new for this sphere. And we would not have created it had the Bank not attracted an excellent consultant ... Without [this person] we would not have created the instrument: [he/she] is the ideologue behind everything, and through [him/her] all this knowledge, skills and competences in creating test items, processing of results, the approaches and methods we use in the developing of the tasks and the assessment scale, all of this is due to the correct scientific advice of [the consultant], no doubt.

(RU-E-07)

Many if not most of these Russian experts have stayed with the organisations running standardised assessments and quality evaluation by circulating within and between different organisations and blurring their identities as civil servants or academics at different phases of their careers. Overall, while in Russia the rise of QAE has made expertise and the individuals possessing it more significant, the demand for education quality assessment and data production has not led to the emergence of structures independent of the national authorities. Instead, national policies and goals permeate all the new establishments, even if their functioning was initially enabled by and relied on the expertise of qualified persons located outside the ministerial apparatus and connected with transnational professional networks.

\section{Conclusion: a transnational expert community}

In the preceding examples, the most dramatic changes in actor constellations after the introduction of QAE agendas happened in Brazil, where we observe a fundamental change of thinking concerning which actors are relevant in 
education policy. In the Chinese and Russian cases, the state authority has maintained a tighter grip on what is happening in the field of QAE in education. Baumgartner and Jones (2009) suggest the main vehicle for change is positive, change-supporting feedback. In Brazil, the state does not exert tight control over QAE policy, as there are many third-sector movements contributing to the agenda. The feedback provided by Brazilian civic movements would not be possible in the state-controlled systems of China and Russia. In China, for example, the results of large-scale evaluations are not disclosed to the public, which does not encourage the demand for improvement in schools' quality. However, we do observe a change of agenda, effected by international organisations and the state-led creation of the QAE expert community.

This chapter also indicates the way in which the case countries were able to develop more QAE capacity during the 1990s and early 2000s. This enhanced data infrastructure and expertise have made national governments less dependent on international organisations, but they have also remained interested in international trends. Despite the bigger picture of the state retaining control of QAE in China and Russia, all our cases have seen change. Brazilian subnational actors, as opposed to national actors, now work with international organisations and their loans. The QAE infrastructure has also allowed civic movements to play a more active role in education. In China, some semigovernmental organisations, such as think tanks, have become more significant as QAE has gained in importance. In Russia, room for action is largely reserved for national agencies and their various tests. However, expert networks play a role in channelling external influence. The role of international actors has changed in all contexts, and in all cases, the countries themselves have been able to direct their influence.

In the analysed cases, there are clear differences in how the transnational QAE agenda has affected national polity. However, a common dynamic is involved in how transnationalism becomes embedded in expert communities. Although the attitude towards international advice has historically varied between and within each country, expert networks are increasing the transnational information flows. This change has occurred gradually, but it is visible in each context. This transnational embeddedness is also supported by the fact that international organisations have sought to intensify their sub-national operations in Brazil. In Russia, the international organisations' operations were largely sub-national during the early post-Soviet period, but their overall role has since been significantly reduced, including at the sub-national level. In each case, the change of agenda has been connected to a change in actor constellations.

\section{Bibliography}

Altbach, P. G. (1991). Trends in comparative education. Comparative Education Review, 35(3), 491-507.

Ball, S. J. (1993). What is policy? Text, trajectories and toolboxes. Discourse, 13(2), 10-17.

Baumgartner, F. R., \& Jones, B. D. (2009). Agendas and Instability in American Politics (2nd ed.). Chicago, IL: Chicago University Press. 
Centeno,V. G., Kauko, J., \& Candido, H. H. (2017). Quality assurance and evaluation through Brazilian lenses: An exploration into the validity of umbrella concepts. Comparative Education 54(2), 132-158.

Cheng, H., Gutierrez, M., Mahajan, A., Shachmurove, Y., \& Shahrokhi, M. (2007). A future global economy to be built by BRICs. Global Finance Journal, 18, 143-156.

Cohen, M. D., March, J. G., \& Olsen, J. P. (1972). A garbage can model of organizational choice. Administrative Science Quarterly, 17(1), 1-25.

Cooper, J. (2006). Of BRICs and brains: Comparing Russia with China, India, and other populous emerging economies. Eurasian Geography and Economics, 47(3), 255-284.

Dahler-Larsen, P. (2011). Afterword. In J. Ozga, P. Dahler-Larsen, C. Segerholm, \& H. Simola (Eds.), Fabricating Quality in Education: Data and Governance in Europe (pp. 151-159). London: Routledge.

Deng, G. (2010). The hidden rules governing China's unregistered NGOs: Management and consequences. The China Review, 10(1), 183-206.

Dente, B. (2014). Understanding Policy Decisions. Cham, Heidelberg, New York, Dordrecht, \& London: Springer International Publishing.

Fernando, L. S. (2002). Theoretical approach to decentralization: An introduction. Journal of Management Science, 1(1\&2), 117-141.

Glosny, M. A. (2010). China and the BRICs: A real (but limited) partnership in a unipolar world. Polity, 42(1), 100-129.

$\mathrm{Gu}$, M. (2010). A blueprint for educational development in China: A review of "The National Guidelines for Medium- and Long-Term Educational Reform and Development (2010-2020)". Frontiers of Education in China, 5(3), 291-309.

Held, D., McGrew, A., Goldblatt, D., \& Perraton, J. (1999). Global Transformations: Politics, Economics and Culture. Stanford: Stanford University Press.

Hsia, R.-J., \& White, L. T., III. (2002). Working amid corporatism and confusion: Foreign NGOs in China. Nonprofit and Voluntary Sector Quarterly, 31(3), 329-351.

Jacobs, L. M., \& Van Rossem, R. (2014). The BRIC phantom: A comparative analysis of the BRICs as a category of rising powers. Journal of Policy Modelling, 36S, S48-S66.

Kauko, J., Centeno, V. G., Candido, H., Shiroma, E., \& Klutas, A. (2016). The emergence of quality assessment in Brazilian basic education. European Educational Research Journal 15(5), $558-579$.

Kent, A. (2002). China's international socialization: The role of international organizations. Global Governance, 8(3), 343-364.

Kingdon, J. W. (2003). Agendas, Alternatives, and Public Policies (2nd ed.). New York, NY: Longman.

Kipnis, A. (2006). Suzhi: A keyword approach. The China Quarterly, 186, 295-313.

Leonteva, M., Plomp, T., \& Voogt, J. (1998). Examination practices in the Russian Federation present situation and perspectives for development. In J. Voogt \& T. Plomp (Eds.), Education Standards and Assessment in the Russian Federation - Results From Russian-Dutch Cooperation in Education. Leuven: Acco.

Luhmann, N. (2002). Die Politik der Gesellschaft. Frankfurt am Main: Suhrkamp.

Ma, Q. (2002). The governance of NGOs in China since 1978: How much autonomy? Nonprofit and Voluntary Sector Quarterly, 31(3), 305-328.

Ngok, K., \& Kwong, J. (2003). Globalization and educational restructuring in China. In K. Mok \& A. Welch (Eds.), Globalization and Educational Restructuring in the Asia Pacific Region (pp. 160-188). Houndmills, Basingstoke, Hampshire, \& New York, NY: Palgrave Macmillan.

OECD. (1998). Review of National Policies for Education - the Russian Federation. Paris: OECD.

Ozga,J. (2012). Knowledge stocks and flows. Data and education governance. In T. Fenwick, \& L. Farrell, (Eds.) Knowledge Mobilization and Educational Research: Politics, Languages and Responsibilities. London: Routledge. 
Ozga, J., Dahler-Larsen, P., Segerholm, C., \& Simola, H. (2011). Introduction. In J. Ozga, P. Dahler-Larsen, C. Segerholm, \& H. Simola (Eds.), Fabricating Quality in Education: Data and Governance in Europe (pp. 1-8). London: Routledge.

Palonen, K. (1993). Introduction: From policy and polity to politicking and politicization. In K. Palonen, T. Parvikko, K. Palonen, \& T. Parvikko (Eds.), Reading the Political: Exploring the Margins of Politics (pp. 6-16). Helsinki: Finnish Political Science Association.

Palonen, K. (2003). Four times of politics: Policy, polity, politicking, and politicization. Alternatives, 28(2), 171-186.

Pant, H. V. (2013). The BRICS fallacy. The Washington Quarterly, 36(3), 91-105.

Postiglione, G. A. (2011). Education. In X. Zang (Ed.), Understanding Chinese Society (pp. 80-95). London \& New York, NY: Routledge.

Qi, T. (2011). Moving toward decentralization? Changing education governance in China after 1985. In T. Huang \& A. W. Wiseman (Eds.), International Perspectives on Education and Society Book Series, Vol. 15, The Impact and Transformation of Education (pp. 19-41). Bingley: Emerald Group Publishing Limited.

Robertson, S. L., Bonal, X., \& Dale, R. (2002). GATS and the education service industry: The politics of scale and global reterritorialization. Comparative Education Review, 46(4), 472-495.

Rondinelli, D. (1981). Government decentralization in comparative perspective: Theory and practice in developing countries. International Review of Administrative Science, 47(2), 133-145.

Sabatier, P. A., \& Jenkins-Smith, H. C. (1999). The advocacy coalition framework: An assessment. In P. A. Sabatier (Eds.), Theories of the Policy Process (pp. 117-166). Boulder, CO: Westview Press.

Scharpf, F. W. (1997). Games Real Actors Play: Actor-Centered Institutionalism in Policy Research. Boulder, CO: Westview Press.

Schmitt, C. (1991). Der Begriff des Politischen. Berlin: Duncker \& Humblot.

Simola, H., Rinne, R., Varjo, J., \& Kauko, J. (2013). The paradox of the education race: How to win the ranking game by sailing to headwind. Journal of Education Policy, 28(5), 612-633.

Suominen, O., Kallo, J., Rinne, R., \& Fan, Y. (2017). Subtle convergence? Locating similarities between Chinese educational reforms and global quality assurance and evaluation trends. Quality Assurance in Education, 25(2), 146-160.

Vedung, E. (2003). Arviointiaalto ja sen liikkeelle panevat voimat [The Wave of Evaluation and the Forces Moving It]. Stakes, FinSoc Työpapereita 2/2003. Helsinki: Stakes.

Werner, M., \& Zimmermann, B. (2006). Beyond comparison: "Histoire Croisée" and the challenge of reflexivity. History and Theory, 45(1), 30-50.

World Bank. (1995). Russia - Education in the Transition. Washington, DC: World Bank.

World Bank. (2007). Implementation completion and results report for the education reform project (Report No. !CR0000303). Retrieved from http://documents.worldbank.org/curated/ en/993451468144562534/Russian-Federation-Education-Reform-Project

World Bank. (2016, January 29). Projects/Brazil. Retrieved from www.worldbank.org/ projects $/$ search?lang $=$ en\&searchTerm $=\&$ countrycode_exact $=B R$

Yang, G. (2005). Environmental NGOs and institutional dynamics in China. The China Quarterly, 181, 46-66.

Yang, R. (2009). International organizations and Asian higher education: The case of China. In R. Malee Bassett \& A. Maldonado-Maldonado (Eds.), International Organizations and Higher Education Policy: Thinking Globally, Acting Locally? (pp. 174-191). New York, NY \& London: Routledge.

Yin, D. (2009). China's attitude toward foreign NGOs. Washington University Global Studies Law Review, 8(3), 521-543.

Zhang, H., \& Wan, D. (2017). Status of Chinese science education reforms: Policies and development framework. In L. L. Liang, X. Liu, \& G. W. Fulmer (Eds.), Chinese science education in the 21st century: Policy, practice and research (pp. 5-30). Dordrecht: Springer. 


\title{
5 Changing expertise and the state
}

\author{
Risto Rinne, Xingguo Zhou, Jaakko Kauko, \\ Romuald Normand, Anna Medvedeva, \\ and Íris Santos
}

\section{Introduction}

Although the state is still a relevant and powerful concept in legitimising actors and directing policy, legitimation through data ownership and experts' instrumental knowledge has become a means of finding more room for action. Several studies have affirmed the role of knowledge in the shaping of education policy and implementation of education reforms on both national and global levels (Normand 2017; Lawn \& Normand 2014). Expertise plays a crucial role in the production and interpreting of knowledge. It is "a specific activity of knowledge production participating in the process of negotiation and orientation of public policy" (Normand 2017: p. 74; see also Ozga 2011). This knowledge is mainly technical and prescriptive/normative and derives from the "professionals working in administrations of the states, international organisations, universities and the HE institutions, agencies, think tanks or interest groups" (Normand 2017: p. 74; see also Weible 2008). Policy arenas like consensus conferences are also central to the academic production of knowledge with various structures and conditions of reception (see Weiss 1979).

In some epistemic communities, experts are mandated and certified to participate in the entire collective learning process. Policymakers thus call on expertise in seeking to reduce uncertainty about information and knowledge in decision-making processes. As Normand (2017: p. 75) writes: "Experts are controlled because it is policy-makers who make the decisions regarding the modalities of dissemination and the use of knowledge. Experts have to respect precise specifications defining the modalities of reciprocal learning and knowledge production." Such policy-expert acquaintances are a means of producing knowledge based on personal relationships between experts and policymakers which differs from the division of labour orchestrated by knowledge centres for the production of evidence-based resources. Types and organisations of expertise differ significantly in serving policymaking.

In some cases, experts have considerable capacity to anticipate emerging political issues because of their previous political and administrative experience and capacity to represent and lead important expert networks. The capacity of anticipation has also shifted from states' and international organisations' 
expertise in traditional planning and prospecting to international consultancy groups like McKinsey or Pearson, with the capacity to elaborate short-term scenarios and knowledge-based technologies and resources. Depending on their influence on and closeness to the media, experts affect the communication and interpretation of selected research findings and studies differently from various groups and audiences. They usually strive to directly influence the media and specific target groups "by adopting a clear, concise and understandable language while using media devices at their disposal (blogs, Facebook, Twitter, etc.)" (Normand 2017: p. 76).

This chapter analyses and contextualises the changing role and relationship of the state and expertise in Brazil, China, and Russia, when large-scale policies of quality assurance and evaluation in school education have been undertaken. Our main question concerns the nature of expertise in reshaping the state's context, status, possibilities, and limits in governing education reforms through quality assurance and evaluation (QAE). In contrast with Chapter 4, this chapter focuses more on the national level than international organisations. Chapter 6 returns to a closer examination of the processes experts conduct.

Usually, the state's interest and approval seek to determine the development and application of QAE, and this is also empowered and supported by QAE data. However, the data generated by various instruments and databases greatly depend on experts, who in many cases generate the lexicon and concepts of data use. Independent experts devise their own instruments and data analysis, but state authorities and structures create a wider, but also restrictive, demand for data collection and use. Concurring data collections exist, which seek to adjust the information collected but which may overload the system. Experts may therefore find their room for action diminished. There is a general mismatch between the demands of experts and state officials. Independent experts' access to state-owned data is also often limited. The roles of and relationship between the state and expertise seem to vary greatly in Brazil, China, and Russia. To tackle these differences, we ask the following sub-questions:

- Who are the main experts in Brazil, China, and Russia recognised as responsible and legitimate actors to collect and interpret data in the QAE of school education policies?

- What kind of relationship and division of labour is there in Brazil, China, and Russia between the state and experts, and is there evidence that this relationship is changing?

- Are the experts and/or state authorities and policymakers willing to limit and restrict or widen and open data use in their practice of the education policies grounded in QAE?

In the next section, we analyse the state's changing role in the historical and social situation of the twenty-first century, which has seen growing global, international, and transnational influences and impacts on nation-states. The third section discusses and analyses experts' growing and changing roles. Our main 
theoretical and empirical points of departure here derive from the wide and deep research tradition of sociology, the political sciences, and comparative educational science in the fields of the state and the changing role of expertise. Most of the research we use here has been undertaken by Western researchers within the frame of the Western research tradition, and it is also interwoven with the views of international organisations such as the Organisation for Economic Cooperation and Development (OECD) and the European Union and the Western worldview. In this respect, they are manifested in many ways in the relatively rich welfare states and may contain angles and perspectives which inadequately fit the circumstances, economies, and social, cultural, and educational heritages of the "emerging countries", to which Brazil, China, and Russia are often said to belong. We are deeply aware of this potential bias and seek to address it seriously in our framework's critical challenge, theory formation, discussion, and analysis. After the theoretical sections on state and expertise, the following three sections analyse and seek to answer our research questions empirically, drawing largely on interview data from each of our case countries. The final section summarises our comparison of Brazil, China, and Russia and takes issue with the more theoretical discussion about the changing relationship between expertise and the state, using the idea of CADEP to understand actors' roles and dynamics.

We conclude by reflecting on the dynamics of attempts to govern the education policies of nation-states with evidence-based technologies through data, numbers, and indicators. The state's role is also shaken by the many profound changes within the countries, including the partial loosening of its strict monopoly of collective decision-making and the new pressures to decentralise and deregulate it, which creates more room for different actors and actor groups, as well as the growing number of experts.

\section{The changing role of the state}

Bauman (1987, 1992, 1998, 2004) has replaced his older concept of "postmodernity" with the concept of "liquid modernity". He emphasises that there are no stable institutions or conditions in the global age and that there are no frames because everything everywhere is constantly in process. "While trust and confidence were constitutive of early modernity, risk and uncertainty are now the hallmarks of liquid modernity" (cited in Kwiek 2006: p. 306). In liquid modernity, the traditional post-war Keynesian welfare state, with its powerful state institutions, is questioned. Current transformations are giving birth to profitability and to "a new kind of capitalism, a new kind of economy, a new kind of global order, a new kind of society and a new kind of personal life" (Beck 1999: p. 2, cited in Kwiek 2006: p. 27; Rinne \& Ozga 2011). Where our chapter's focus is concerned, this should also affect the relationship between the state and experts.

These changing questions of power boil down to the term "governance", which is used in many social science disciplines as an interdisciplinary bridging concept (see Schuppert 2006: p. 373). There is no agreed-upon definition 
of the term: governance is used to describe new forms of steering/regulation (Benz 2004). From the outset, it is important to note that governance is not a narrow theory but rather an analytical approach which draws attention to important changes in political perspective. These shifts in perspective concern the use of governance to conceptualise regulatory and governance activities which concepts such as "steering", "governing", "control", and "interdependence" have conventionally favoured. Governance addresses "government", "management", "coordination", "regulation", and so on among the different actors within the state, market, economy, and civil society non-hierarchical and network structures (Benz et al. 2007; Ball \& Junemann 2012; Loncle, Parreira do Amaral, \& Dale 2015).

Governance emerged as a political concept at a time of criticism and scepticism concerning the possibilities for a linear and hierarchical regulation of complex social systems. This points as much to a change of perspective concerning forms of regulation and coordination in modern societies as it does to any profound transformation (Mayntz 2006; Dale et al. 2016).

Patrick Le Galès defines the substance of governance as

[A] coordination process of actors, social groups and institutions that aims at reaching collectively defined and discussed objectives. Governance then concerns the whole range of institutions, networks, directives, regulations, norms, political and social uses as well as public and private actors which contribute to the stability of a society and a political regime, to its orientation, to its capacity to lead, to deliver services and to assume its legitimacy.

(Le Galès 2004: p. 243; cited in Dale et al. 2016)

Changes in governance resulting from the new steering tools the expert community usually uses have been widely noted. In Chapter 6, we present a critique of Rose's and Miller's idea of "steering at a distance", which follows from the analysis of our case countries. However, it is helpful to understand that the principles of calculability and measurability originating from economics used by the private sector have increasingly been transferred to fields previously regulated by old bureaucratic statutes and professional norms, usually located in the public sector. Rose (1999: p. 152) refers to the new governance technology based on accountability and assessment to which the public sector is subjected as "governance at a distance" (Rinne \& Ozga 2011: p. 67). This steering has consequences, as Rose puts it, for the shift to an "audit society", where every new space subjected to comparability, measurability, and transparency summons its population to evaluate and measure itself and translates its activities into measurable and economic language to maximise efficiency and income, while arbitrary rules are "tamed, liberalized and acknowledged as neutral and objective calculation and evaluation" (Rose 1999: pp. 152-154; Rose \& Miller 1992, cited in Rinne 2001: p. 107).

Similarly, Michael Power has developed the concept of the "global inspectorate or audit society" $(1999,2003)$, and he observes that evaluation entails 
a "control of controls" and "rituals of verification" (cited in Rinne \& Ozga 2011). In political science, the focus on understanding governance structures and processes as opposed to governments' structures and processes occurred more than a decade ago. Briefly, this focuses on the shift from centralised and vertical hierarchical forms of regulation to decentralised, horizontal, networked forms (e.g., Rosenau 1999). Although it is widely acknowledged that governance is a phenomenon which produces broad patterns reflecting dominant political forces, it is also important to note that it is understood as a continuum which "stretches between the transnational and the subnational, the macro and the micro, the informal and the institutionalized, the state-centric and the multicentric, the cooperative and the conflictual" (Rosenau 1999 cited in Ozga et al. 2011: pp. 89-90).

Where steering tools are concerned, the OECD's knowledge-based regulatory tools vigorously attempt to promote orthodox professional practice and the increased standardisation of professional formation and development. The strength and power of these tools lie in their apparently objective nature, in the attractiveness of the space for negotiation and debate they create in which experts, policymakers, and other knowledge-brokers meet and position themselves, and in their capacity to define the terms of that engagement (Rinne \& Ozga 2013: p. 97). Pons and Van Zanten (2007) suggest these tools have three main elements: (i) they reflect particular "world visions" which represent the agenda-setting capacities of particular interests; (ii) they represent a particular and politically oriented set of beliefs concerning legitimate policy in a given domain; and (iii) they represent a wide and growing network of actors who are constantly drawn into the process of intelligencegathering, auditing, and reflective policymaking (cited in Rinne \& Ozga 2013: p. 97).

To grasp the implications of the increasing complexity of the emerging multi-scalar/multi-level governance arrangements in each country, we need to devise a new lens through which to examine the issues. Dale sees this as a major shift:

With new forms of complex governance, the state form ... loses its monopoly position in the production of collective solutions to the collective problems. Collectively binding decisions are no longer taken by the state alone, or among sovereign states, but rather with the involvement of various types of societal actors, sometimes even without governments.

(Dale 2009: p. 30)

Dale and Robertson (2012: p. 23) make a similar argument and emphasise a change in the

national education system to a more fragmented, multi-scalar and multisectoral distribution of activity that now involves new players, new ways of thinking about knowledge production and distribution, and new challenges 
in terms of ensuring the distribution of opportunities for access and social mobility.

(see also Dale 2003)

Verger, Lubienski, and Steiner-Khamsi (2016: p. 4) also analyse the growth of the "global education industry" and observe that its emergence has entailed the development of new market niches "that are often outside of traditional state control, such as preparation, edu-marketing, the provision of curriculum packages or school improvement services".

However, it is important not to exaggerate the state's defeat here and succumb to what Weiss (1997) calls "the myth of the powerless state" (cited in Ball 2007: p. 36). Indeed, despite an increasing international interdependence which seems to generate pressure to converge, advanced industrial societies continue to exhibit differences in their institutional practice. As Andy Green (1999: p. 56) observes,

As regards education, there is very little evidence across the globe that nation states are losing control over their education systems or ceasing to press them into service for national economic and social ends, whatever the recent accretions of internationalism. In fact the opposite may be true. As governments lose control over various levers on their national economies and cede absolute sovereignty in foreign affairs and defence, they frequently turn to education and training as two areas where they do still maintain control.

The orthodox conception of national education systems effectively draws together distinct functions and sets of rules and beliefs. Those which have been

historically rooted in an assumption of the centrality of national economies for instance, that the function of education systems was to provide educated labour for the national economy and that education systems would shift and separate the potential workforce, according to ability and potential contribution to the economy. Another assumption was that education systems are crucial to the construction of national culture, integration and sense of national belonging.

(Parreira do Amaral \& Rinne 2015: pp. 80-81)

Our questions concerning the changing role of state and experts in this chapter are much the same as Ozga's (2015: p. 30) note on the paradox of "fundamental commitment to reducing the role of the state and enabling system and self-regulation through the market" and "the need to use state regulation in order to get the market to function properly", which in turn "is creating constant pressure for increased regulation and centralization". Citing Kandel (1938: p. 29), she warns:"The danger that confronts mankind to-day comes not 
from the expansion of education, but the specialization in some narrow corner of the field of knowledge. The specialist faces the world to-day as the blind man the elephant and fails to see life steadily and see it whole" (Ozga 2015: p. 31).

\section{The context of expertise}

The complexity of governance, and thus the operating environment for experts, is increasing. Bob Jessop (2002: p. 199) calls this "destatization", which involves "re - drawing the public - private divide, reallocating tasks, and rearticulating the relationships between organizations and tasks across this divide". Alongside these changes global education policy communities are constituted through which new policy discourses and narratives flow. The new global policy networks are built by a

diverse set of think tanks, consultants, multi - lateral agencies, donors, education businesses, and philanthropies, [which] constitute policy communities that are based upon shared conceptions of social problems and their solutions. New narratives about what counts as a 'good' policy are articulated and validated.

(Juneman, Ball, \& Santori 2016: pp. 537-538; Ball 2007)

Private providers are now also involved at different levels and scales, through advice, consultation, evaluation, philanthropy, partnerships, representation, programme delivery, and outsourcing in the provision, monitoring, and evaluation of public-sector services. This has "brought new players, voices, values, and discourses into policy conversations" and "governance by networks": "webs of stable and ongoing relationships which mobilize dispersed resources towards the solution of policy problems" (Pal 1997; cited in Juneman, Ball, \& Santori 2016: p. 537). The situation is of course somewhat different in Brazil, China, and Russia, but most of these private providers have gained a foothold in them as well (see Chapters 6 and 7).

Data and data systems support the growing activity of expert networks, which aim to identify and frame policy problems and solutions nationally. Networks of new actors and experts also exist. A major expansion of education consultancy and provision of educational goods and services contributing to the promotion of standardised testing and "standardizing doxa of best practices" is taking place. A range of sophisticated standardisation instruments, quality benchmarking, and data harmonisation "underpin[s] the governance turn[s] and act $[\mathrm{s}]$ on and within the national systems promoting ways of controlling and shaping national, institutional and individual behavior". New data enable the state to work on schools and localities as a resource for steering state policy in its entirety and compel experts to move "beyond the traditional task of informing policy and [become] policy forming in a more complex form of governing" (Fenwick, Mangez, \& Ozga 2014: p. 5). 
In defining the function of experts, Lawn and Segerholm (2011: p. 45) emphasise the transnational nature of their work:

Experts aid the flow of data across countries, and so act to constitute a new spatial infrastructure to emerge around education. Through shared databases, policy officers, technical experts and meetings, new synapses operate through which messages of comparison and commensurability (messages of standards, ranking scales, indicators and benchmarks) are passed.

All this is happening between national agencies and the OECD, which are the major players in constructing a common education space through the flow of data. Data may be called "the currency of governance". Similarly, Fenwick, Mangez, and Ozga (2014: p. 4) claim that to understand and capture globallocal interactions, we should take seriously Sassen's (2010: p. 10) injunction to think of the "global - whether an institution, a process, a discursive practice, an imaginary - as both transcending the exclusive framing of nation states and partly emerging and operating within that framing".

In developing countries, education policy has relied on the discursive construction of state failure (for example, in limited access and poor quality). Robertson and Verger (2012) suggest a strong generalisation regarding the "developed" world has been accompanied by "a purposeful framing of causes and issues (failing state, lazy teachers, lack of incentives, lack of accountability, dysfunctional schools) and a selective use of evidence". These have been articulated by "neo-liberal rationalities that link market mechanisms such as choice and fee payment to greater accountability and education quality" (Juneman, Ball, \& Santori 2016: p. 538). However, this is not especially characteristic of Brazil, China, and Russia, where choice and fee payment are concerned.

The governance of education is thus increasingly understood as taking place through cross-sectoral networks of public, private, and third-sector interdependencies which crisscross national and transnational boundaries. This "networked governance" is decentralised and characterised by fluidity, looseness, complexity, and instability (Ozga, Dahler-Larsen \& Segerholm 2011; Williamson 2012). Post-bureaucratic networked governance is conceived as "soft power", which works

through techniques of attraction, seduction, persuasion and the cultivation of support and shared interest across networks of loosely associated actors. Soft forms of governance include self-regulation, self-evaluation, selfgovernance and governing through the capacities of the governed, rather than the hard government of centralized targets and external regulation.

(Williamson 2014: p. 218)

Our analysis sees experts as actors practising "a specific activity of knowledge production participating in the process of negotiation and orientation of public educational policy" (Normand 2017: p. 74; see also Ozga 2011; 
Lawn \& Normand 2014). In the following empirical section, experts are those engaged as consultants, researchers, scholars, and lecturers in the field of education.

\section{The state and expertise in Brazil}

The Brazilian expert community is strong and has already been transnationally linked for many decades (Kauko et al. 2016). In Chapter 4, we observed that the changes in agenda partly relayed by these networks have transformed the political constellation of actors in Brazilian polity. In this chapter, we focus more on the potentially most influential expert body.

The experts in Brazil recognised as responsible and legitimate actors for the collection and interpreting of QAE data in the field of school education policy are located in the main national expert body for large-scale assessments, the National Institute for Educational Studies and Research (INEP), which is responsible for Brazil's main education indicators, such as the Index for Development in Basic Education (IDEB). There are other important expert bodies, third-sector movements, and think tanks in the Brazilian expert community, but none surpasses the INEP in its scale of data production, which is why we concentrate on this organisation in analysing the changing role of expertise. To tease out the answers to this chapter's central questions, we need to investigate interviewees' descriptions of the scope and potential of the INEP on different levels of action.

Our chapter focuses on the nature of the relationship and division of labour in Brazil between the state and experts. We have already adduced evidence of this change in Chapter 4. In this chapter, we observe a strong willingness to cooperate with the INEP on different levels. Policymaker interviewees described the INEP as a close collaborator. The Chamber of Deputies Standing Committee on Education, for example, holds expert hearings with the INEP and Ministry of Education (BR-N-11, written communication). The INEP also closely collaborates with the Ministry of Education in producing analytical tools (BR-N-02). However, at the sub-national state level, there is more demand for training than the INEP can offer (BR-N-09). In this sense, in relation to the scope of the INEP's operations, we can see that it receives strong legitimisation from different actors.

Our interviewees also pointed to the principle that the Ministry of Education is not allowed to deal with political questions at sub-national levels. One interviewee stated that large-scale assessments still provided the Ministry of Education with information regarding work in the great majority of municipalities and states but allowed such separation and non-involvement. Indeed, the interviewees' wording indicates there is no willingness in the Ministry of Education to use large-scale assessment as a tool:

The Ministry of Education does not aspire to have more political power in the field of educational policies in the area of basic education ... [T]he 
formulation of large-scale assessments is certainly not a strategy to gather more power.

(BR-E-02)

In analysing whether Brazilian experts, state authorities, and policymakers are willing to limit and restrict or widen and open data use in practising education policies grounded in QAE, our interviews suggest that the INEP has more power than it currently exerts. However, there were contradictory understandings of how independent the INEP was of the political process. An INEP expert argued for more autonomy for the organisation. This interviewee described an incident in which it was alleged that the INEP was postponing publication of a report because of government pressure. Our research cannot verify if this happened, but it indicates actors' perception that the Ministry of Education retains some influence on the publication of results and that the INEP is not completely independent.

Then it happens, eventually ... The ministry interferes, saying "Wait a moment, calm down, for me this isn't a good time for you to say that, there is an election now, in a little while, then no, no, it is not so interesting to publish that." No one will interfere in an autonomous institution, but it needs to be $100 \%$ autonomous. With the dissemination of some results, last year it was questioned, regarding the deadline, if there was interference or not. I would not be able to tell you, but I'll tell you that if there's a cat's tail, a cat's ear and it meows it is probably a cat. I do not know if there was, but there's some reason to think so. I would expect the INEP to be more autonomous than that.

(BR-E-06)

In analysing experts' and policymakers' willingness to limit and restrict or widen and open data use in practising the education policies grounded in QAE, we found that, although there is no consistent view, the self-understanding of the INEP was more that of an expert than a policymaker, which created difficulties with political issues, as the preceding quotation indicates. However, some also emphasised that the INEP was almost a prerequisite for decision-making and that without it there could be no policy monitoring.

The INEP's status is as a national agency, meaning it has relative autonomy with respect to the Ministry, but maybe it is one of the agencies that suffers a more direct impact from policy decisions. [The INEP is] subject to political decisions with little dialogue. It is also my perception that there is little dialogue and it feels ... that we are often performers and that goes against the identity of the researcher. This is the dilemma that we suffer: how can I be a researcher if I feel I am a political performer? It's like I don't have . . I can think but I can't perform what 
I think but what someone has told me to do. It's a pretty important ambiguity.

(BR-N-09)

The main data of Brazilian education today are produced here within the INEP. Information is fundamental not only for the elaboration of policies but for monitoring of policies. Do you understand, then for example, there is work done by the Presidency of the Republic on problems, inequality in Brazilian schooling, etc.? They constitute an observatory for the Presidency of the Republic and the data are collected by the INEP, you understand, so without the information provided by the INEP you cannot only elaborate the policies but monitor them.

(BR-N-04)

A different view was offered by a state-level politician, who pointed out that a major reform of the matriculation examination (vestibular) was being implemented without consulting experts.

In 2009 the Minister decided that he would replace, roughly speaking, the Brazilian vestibular but had no dialogue with the team, no internal dialogue to find out what this team of researchers thinks about it.

(BR-N-09)

It might be concluded that the large-scale assessment data the INEP collects allows it potential room for action, but this potential is not realised because of the actor relations and set practices just described. However, the organisation can address problems through public discussion. Although it was alleged politicians were trying to influence the INEP, we observed no consistent pattern, and in general, the organisation seemed quite autonomous. Chapter 6 points out that interviewees reported policy processes in which although the INEP's expertise is available, policymakers do not always consult it in preparing important decisions. Its role is ambiguous: the Ministry of Education's distance and the INEP's orientation do not support political interference, but in some cases, the political process finds its way around the experts.

\section{The state and expertise in China}

In China, expertise and the state have an entwined relationship that is ingrained in the Chinese culture of meritocracy, which "originated in the philosophies of Confucianism and Daoism during the fifth and sixth centuries BC and developed with the Legalists in the subsequent centuries" (Liu 2016; Yao 2000). The Confucian stance on this issue is that an excellent student or scholar should pursue a political career and an excellent politician should also become a good scholar (see Legge's translation 1983). Pursuing a political career was the only 
proper goal of education in the context of Confucianism. Liu (2016) writes that the direct manifestation on the institutional level was the civil service examination system known as kējur, through which the government selected government officials. Those who passed kejju became government officials and were given power and authority to govern because of the trust the educated enjoyed as a result of their knowledge and expertise, which enabled them to better understand how to govern or manage social issues. However, those who did not fit into the system often chose to serve the aristocracy as advisers móu shì. The civil service examination system was abolished in 1904, a few years before the end of the last Chinese imperial era. But the legacy of meritocracy remains deeply rooted in Chinese culture, and this is manifested in the current political system in elite governance or authoritarianism (Han \& Ye 2017).

The relationship between expertise and the state best explains the contemporary meritocracy. Our findings reveal that policymaking expertise is largely provided by researchers from various domestic and foreign research institutions and universities. They still play the role of advisers to policymakers, assisting them to understand what the real problems and possible solutions are. The final decision in policymaking remains in policymakers' hands, however (Han \& Ye 2017).

When we seek to identify the main experts in China recognised as responsible and legitimate actors in collecting and interpreting data in the field of QAE policies, we observe that the state usually collaborates most directly and closely with top-ranked universities and research institutes associated with the central government. Traditional units, such as research institutes, universities, and even researchers, may to some extent collaborate with the state through applying for funding from state-funded foundations or being directly appointed by the state to collect data. Social connections play a major role in the allocation of such cooperation opportunities (Buckley, Clegg, \& Tan, H. 2006; Park \& Luo 2001; Wong \& Tam 2000), which enables researchers with more extensive social and political connections to receive more academic research projects from the government. Another approach of the state is to establish new research centres or institutes based on government planning of the political agenda. An example is the National Assessment of Education Quality (NAEQ), which was established in 2007 to collect nationwide standardised testing data (Zhou et al. submitted). New testing contrasts with the traditional examination method, which has been the dominant means of evaluating, assessing, and ranking students' learning outcomes. However, this new testing carries the ambitious political task of diagnosing the "real" education problems with reliable and sophisticated empirical data. It is creating a nationwide databank based on the annual assessment of students' academic performance and other elements influencing such achievement. To accumulate indicators for this new testing system, the state has established a special NAEQ centre, employing researchers from top universities both in China and from abroad (Zhou et al. submitted). The official newsletter of the NAEQ states that more than sixty universities and research 
institutions are involved in the testing of indicators for different school subjects. This testing has been inspired by many large-scale assessments like the Programme for International Student Assessment (PISA) and NEPS (the German National Educational Panel Study).

When we ask what kind of relationship and division of labour exists in China between the state and experts and if there is evidence that the relationship is changing, we observe that the state tends to rely increasingly on evidencebased data. Besides the new testing system, the state is also the main resource for research funding. Many research foundations, such as the National Planning Office for Philosophy and Social Sciences (NPOPSS), are among the largest state foundations. An indication of this increasing tendency is that the NPOPSS has started to fund more education projects. In 2015, the NPOPSS funded a total of 202 projects (NPOPSS 2016) covering broadly educational topics. In 2011, when data collection concerning this began, it funded 167 (NPOPSS 2011).

The Chinese state channels academic research focus. Government funding is usually used by the state as a pre-policymaking test. Research proposals therefore share the concerns of the government's agenda. The state signals the government's agenda or focuses through documents and leaders' speeches. Newspapers and academics then focus on these topics. For example, one of the main concerns of the government is how to solve the imbalanced distribution of education and social resources, and QAE's academic research seeks to take this concern into account in using QAE to achieve this. This issue was repeatedly mentioned by various interviewees. It is commonly understood that if someone wants to receive government funding for their research project, their proposal needs somehow to be connected with the topics prioritised by the government agenda. One interviewee stated,

Our country [refers to the government], for example, now emphasises the importance of college entrance examination reform, so we will focus on this ... in the college entrance examination reform [of group publications related to this issue]. For example, we will ask how to change the college entrance examination, how to use the academic achievement test in the college entrance examination, how to operate the academic achievement test ... and then our focus will be transferred to these issues.

(CN-E-08)

Experts play the role of knowledge-broker to inform the state and other stakeholders about the situation of education, based on their research results. They have connections both with the state in decision-making and with schools in implementation. Both connections mean that experts influence decisionmaking through the utilisation of their research results' evidence and authority.

[T]hrough this analysis [refers to their project] ... [our] main purpose is first to go to help the schools. By analysing the results of the teaching process, we hope to help them [refers to teachers and schools] 
to improve teaching and situations, and their research results are also reported to the government for policymaking reference. The second purpose is to report the situation to the government so that they can learn about situations in schools to reflect on policymaking. Our second task is to do policy research to help the government with improvement of policy.

(CN-E-11)

Experts are largely involved in the consultation stage, but whether the decisionmaker accepts the results and the extent to which schools can change their practice appear to be problematic areas. The state has the final decision concerning policymaking. A rector of a prestigious research institute told us how much their work can influence policymaking:

The government listens to different voices ... When a researcher delivers a report based on their findings, the government starts to hold different meetings to listen to voices from different levels. For instance, how parents think about or feel about this policy. After many rounds of meetings the government publishes the final version of the policy, which looks a bit like a decision based on your findings and also a bit like a decision based on other researchers' findings.

(CN-E 06)

Policymakers and experts appear to have become a mutual benefit community (Han \& Ye 2017), which helps and promotes their respective agendas. National policymakers have the widest choice of national, local, and international academic resources, but they are most likely to cooperate with researchers from an equivalent level. For example, the central state usually selects institutes based on their reputations and ranking. Likewise, provincial decision-makers generally receive academic support from regional universities. Data are more likely to be circulated within a political group and among key stakeholders. However, policymakers and experts do not really form a community. The boundary is clear. The researcher is responsible for data production, while the government is responsible for the production of policy based on these data: "It is government's responsibility to decide when and how to release it" (CN-E-07).

In investigating the willingness of Chinese experts and state authorities and policymakers to limit and restrict or to widen and open data use in their practice of QAE education policies, we observe that national and provincial governments prefer to utilise research results from various sources to support their decisions, and even policymakers themselves become experts on data and numbers. These various sources generally emanate from an individual researcher, a research group or team, research institutes, and specially funded problem-based research centres. The Chinese government has supported prestigious Chinese universities in growing their research competence in the global education 
market through their involvement in international academia in increasing impact factors, rankings, and publications.

The Ministry of Education has multi-channel resources. We have the National Bureau of Statistics which is the authority for all types of statistics. Most documents and policies draw data from this place. The Ministry of Education also uses universities, research institutions, and local governments to provide data to the Ministry of Education.

(CN-E-07)

However, these multi-channel resources only fit the national level. Distribution of expertise is uneven. Skilful experts are recruited from national universities and serve in national policymaking. At the local level, however, there are fewer expert resources.

There are two skins [two separate sets of actions which have little connection] in terms of reforms of educational assessment and evaluation. The indexes created at national level introduced a new concept of evaluation, and designed an assessment process ... so the provincial government, including the county government, coordinates the assessment. Then the results go back to Beijing [the central government] and have no relationship with locals. So, the locals just continue the old practices, following the traditional ways like supervision because they know them well.

(CN-E-12)

However, implementation of central policy depends on the regions. Local government and schools in most Chinese regions are not equipped with equally skilled and knowledgeable experts, which may harm implementation and make a real difference at the local level.

\section{The state and expertise in Russia}

Russian experts contribute to international, national, and sub-national discussions on education and maintain communication between these levels. From the state's perspective, they are legitimate actors responsible for collecting and interpreting data in the field of QAE compulsory education policy. Some worked in federal agencies during the 1990s and later moved to the research sector, which focuses on measurements and the analysis of their results. Although they are autonomous in their international communication, instrument planning, and collaboration with the regions, their projects are often stimulated by the state's targeted financing, or they need to look for sub-national partners and funding to sustain their research work.

International contacts ensure awareness of education developments elsewhere. Technical and other innovative ideas are applied in national tests and in developing and analysing test items. For example, this occurred when PISA-like 
assignments were introduced to the Unified State Exam (USE) after national specialists participated in seminars in the Netherlands (RU-E-12). Communication with colleagues from abroad stimulates the growth of national expertise concerning assessments. The interviewed experts insist that this was not a unidirectional relationship in the 1990s, since Russian experts were not passive recipients of assistance and guidance from international agencies. From an early stage they have collaborated internationally on equal terms.

It is well-known, publicly available, that [international] colleagues did a lot for the development and acknowledgement of the Russian instruments. It would be wrong not to mention this. However, this is a big collaborative work. It is impossible that someone came from abroad, an expert, however qualified he is, but it is impossible to come to the territory, country, and change something there. It would be wrong. If the team has been formed, if there is a constructive moment ... dialogue, then everything changes, you can take the best, and there is a partner-like relationship, it is important.

(RU-N-02)

Attaining knowledge on the specifics of the system of education spurred the advance of the assessment instruments; later changes included defining education standards and development of textbooks. However, the connections on this level show the primacy of the state in defining the agenda, while experts foster the discussion about the problems of the education system.

(RU-E-04)

The relationship with sub-national and school-level specialists is more collaborative. The development of new instruments, for example, an assessment of children's readiness for school and subsequent assessments across primary schools, occurs through cooperation. This means reorienting schools towards development based on available data and giving teachers the opportunity for discussion and reflection. In this case, experts involve school specialists in education analysis, and they maintain the link between nationally identified priorities and practices (RU-E-12).

However, the federal government is the major player in data production, analysis, and dissemination:

You know, everywhere, always we continued because for the primary school we had a project of Rosobrnadzor. It means that there is an organisational structure, money, people, plan, results which you aim to achieve. Plus, you add something of your own, what you think is important to develop in this direction.

(RU-E-12)

For example, when Rosobrnadzor's support switches to other initiatives, experts and school-level specialists have less room for action. They are unable to 
continue with initiatives they have already started, because the state focuses on the new instruments.

Another example of experts' collaboration at the sub-national level is their analysis of the situation of schools facing challenging circumstances. This is a matter of current national interest and therefore receives support. Since there is less federal regulation, at least currently, there is more room for action for experts and school-level specialists (RU-E-04).

Even when the analysis demonstrates a need for change, there are problems in developing practical solutions. Specialists are needed who will collaborate with schools and regional governments (RU-E-07). Teachers should be able to understand tests and the objective assessment system (RU-E-10).

Finally, media actors collect data about rankings from open sources. An example of such a project is "Social Navigator", an agency and web resource which aggregates information about public services for extensive social use. They present their work as being about public accountability rather than the pursuit of scientific goals, which is a key difference from the experts' focus. They promote key findings for the information of the public and do not strive to influence governance (RU-E-11).

The relationship and division of labour between the state and experts in Russia is built around data collection, ownership, and analysis. Its utilisation by different actors varies, depending on their analytical interests and their decision-making power in education. The evidence of change is manifested in the state's greater presence at all these stages. The ministry limits experts' access to large-scale data, and decisions are often not based on open professional discussion. The state stimulates the development of new instruments, but when there is a shift towards new funding priorities, the regions struggle to sustain these initiatives.

Experts connect transnational and national education policies; international assessments help experts in legitimising certain ideas on the state level, although there is often a delay in implementation:

I think we always work in advance, this is the feeling of the time-frame of our activity, because the expert world is much more saturated with information. We travel somewhere, we read, and we get rushed. We want models, approaches, and ways of life to work everywhere, to work where we are. Then, this time lag emerges, and we feel that nothing happens. And if after some time some documents articulating education policies emerge, there is a signal from above [informal approval of the state officials], it is hard to understand if we weren't involved. What we did before was to create an information field and discussion, because we don't write just for ourselves, you know. It all emerges in the press and becomes a part of the public discussion.

(RU-E-04)

Typical situations creating political opportunity are presented when performance in some test is particularly low, and the analysis identifies problems 
(see Piattoeva \& Gurova 2018). An example is PISA and the discrepancy between its results and those of the Progress in International Reading Literacy Study (PIRLS), which has pointed to the weakness of students' curriculum knowledge-transfer to applied tasks (RU-E-12). These cases validate experts' ideas in the eyes of state officials.

Experts' influence on the agenda is limited because of the state's ownership of data. Moreover, the interest and approval of state officials determine the development and application of any instrument and subsequent data gathering and analysis.

However, the state is also empowered by data, which creates a need for relevant statistics to support current policy priorities. This stimulates a selective approach to statistics, in which only suitable information is extracted to justify an agenda, instead of decisions being developed through data analysis. Specialists criticise this case-driven use of inferences which diminishes the demand for analytical work.

However, even when specialists have an opportunity to offer analytical support, their expert advice is often unappreciated:

Look, there is an expert who is asked, he has to respond. I would say it is a problem when they [government officials] ask. If they first ask, and then you answer, so that someone can take it into consideration, I think this is okay. But if something is done, decided, and then they ask you for some reason. For instance, there was recently a discussion in the Civic Chamber, the ministry presented a model of the graduate portfolio, the portfolio of a university graduate. We came there, they did not invite us, we just came. We tried to comment, and the answer was "everything is already decided".

(RU-E-04)

Moreover, when cabinet positions change, the pool of trusted experts is reformed. Several experts we interviewed used to work in the governance structures of the 1990s, but they are now occupied with analytical work. Other specialists are more aligned with governance structures.

The question of whether Russian experts and state authorities are willing to limit, restrict, or widen data use in practising QAE education policies reveals acknowledged problems both in data collection and its application in decisionmaking. Although there is an abundance of statistics on many issues, a key datarelated problem for experts is their uneven collection. For example, context data about schools were previously available in the "school social passport", but this instrument was cancelled. Given Rosobrnadzor's desire to promote evidence-based decisions, experts' hope is that once a specific data deficiency is identified, officials will request a specialist consultation. However, the education managers and state officials who order such instruments often fail to understand the kind of instruments which might be developed. The cost of undertaking tests also precludes development in this direction. When large data sets are accumulated, sufficient specialists for every school district are required to 
analyse them (RU-E-02). Monitoring is discussed as the next goal of the education system's transformation, which will assemble an all-encompassing set of indicators, but there is a concern about how this data will be used (RU-E-04). Although efforts are made to base decisions on them, experts are sceptical about how management is exercised in education policy:

It is called evidence-based decision-making, but it is exotic for our country. We don't have that for sure. The decisions are still being made based on opinions: the one who is louder, who has a higher status, who is more respected, is the one whose opinion is heard more. In that sense it is good that this is already articulated.

(RU-E-02)

It is understood that "it is important to note who showed you that piece of data". Its use is often determined by a need to demonstrate something on the spot (RU-E-03). Specialists are concerned about how state officials handle data, because their insights are frequently ignored (RU-E-03).

The attitude to rankings explains the difference in the positions of experts and education managers. The proponents of this instrument claim it should be used for general information purposes as a quick illustration, supported by extensive data (RU-N-04; RU-E-05; RU-SN-1). However, experts point to the scarcity of publicly available data from which rankings are drawn (RU-E-11). Officials acknowledge that rankings do not allow an analysis of the circumstances of poor-performing schools, which is among the governance priorities (RU-N-04). The instrument does not address challenges in attaining good results. Yet results are often used to praise or admonish educational institutions, because education managers lack the skills to interpret data.

There is a general mismatch between the demands of experts, who refine the measurements in their scientific work, and state officials, who seek justification for the policy agenda. Specialists exercise autonomy within their analytical work, but this depends on government funding and access to data.

\section{Conclusion: the changing role of the state and room for experts in QAE policy in Brazil, China, and Russia}

This chapter's aim was to analyse and contextualise the changing role of and relationship between the state and expertise in Brazil, China, and Russia when large-scale quality assurance policies and evaluation in school education are undertaken. We examined more closely how the nature of expertise reshapes the state's context, status, potential, and limits in implementing and governing education reform.

As already indicated, the previous research on governance and expertise emphasises the state's changing role, the complexity of national decisionmaking, and a shift to a regime of governance by numbers. This is partly true in how both expert communities and the state are willing, at least rhetorically, 
to build a community in which shared interests benefit from cooperation. For example, in Brazil, we find a strong willingness to cooperate with the INEP on different levels. In relation to the INEP's operational scope, we observe that it receives strong legitimisation from different actors. In China, the state also tends to rely increasingly on evidence-based data, even to the extent of establishing a new testing system. In Russia, independent experts exercise extensive autonomy in indirectly influencing education content. The state and experts cooperate, with experts providing analytical assistance, while the state owns data. The state now demands increased data collection.

Our analysis confirms that some of the claims presented in previous research from a global perspective may slightly exaggerate the situation in Brazil, China, and Russia. Expert bodies certainly have some power and, more specifically, potential for power. However, the state and expert communities influence the whole of society and community. There are tensions between controlling data and being controlled by it and who interprets and who publishes data. These tensions are more visible in some cases than others. In Brazil, for example, the INEP is perceived as quite autonomous, and it enjoys public trust, yet it is not entirely free of political influences, which to some extent call into question its autonomy. If an expert body's orientation does not support a political proposal, the political process can find a way of circumventing the experts. A similar phenomenon can be seen in China. Both national and provincial governments have always looked for data and academic research results from various sources to support their decisions, but they have always been the final decision-makers concerning which and whose data to use. In Russia, although there is an abundance of figures on many issues, experts' key data-related problem is its uneven collection. For example, context data about schools were once available within the "school social passport", but this was cancelled. Independent experts have limited access to state-owned data. The ministry accumulates data to support evidence-based policy without extensive professional discussion. The results of the USE are unavailable for academic analysis unless they are acquired from individual schools (which is problematic for large-scale analysis). At the same time, USE results and other data are widely used in rankings. There is therefore a scarcity of context data, such as regional socio-economic indicators. These deficiencies impede "rule by data". In Russia, the state can limit and restrict data use.

Policymakers' and experts' basic relationship with assessment data use differs. Whereas policymakers can work with or without data, experts depend on it. Whereas policymakers can bend interpretations, experts attempt to adhere to what is analysed. Experts' independence from state organs is another important issue. These differences in understanding data use also reflect the basic dynamic of the relationship between the state and experts.

There is a clear convergence in QAE politics in Brazil, China, and Russia: all have striven to expand the collection and use of QAE data by experts. States have established new institutions and organisations to widen QAE practice. The scale and growth of expert participation in QAE formation and interpretation 
have been impressive, and many of the characteristics of the "expert state" have emerged. However, there is a clear boundary for such expert participation. In each country, the division of labour in QAE and the possible limitations and restrictions of data use have been discussed. Experts are trusted to produce and collect data, but full usage of data is to some extent restricted or interfered with by political agendas.

However, Brazil, China, and Russia differ markedly in their history of collecting and using QAE data. Brazil has the longest history of institutionalising modern QAE data production and dissemination. In China, there has been a longstanding and very different tradition of pupil assessment, and the modern QAE system is relatively recent. In Russia, the tradition resembles China's more than Brazil's. We conclude that the state's role in QAE governance is more powerful in China and Russia than it is in Brazil.

\section{Bibliography}

Ball, S. J. (2007). Big policies/small world: An introduction to international perspectives in education policy. In B. Lingard \& J. Ozga (Eds.), The RoutledgeFalmer Reader in Education Policy and Politics (pp. 36-47). London \& New York, NY: Routledge.

Ball, S. J., \& Junemann, C. (2012). Networks, New Governance and Education. Bristol: The Policy Press.

Bauman, Z. (1987). Legislators and Interpreters: On Modernity, Post-Modernity and Intellectuals. Cambridge: Polity Press.

Bauman, Z. (1992). Intimations of Postmodernity. London \& New York, NY: Routledge.

Bauman, Z. (1998). Globalization: The Human Consequences. Cambridge: Polity Press.

Bauman, Z. (2004). Wasted Lives: Modernity and Its Outcasts. Cambridge: Polity Press.

Beck, U. (1999). World Risk Society. Cambridge: Polity Press.

Benz, A. (2004). Einleitung: Governance - Modebegriff oder nützliches Sozialwissenschaftliches Konzept? In A. Benz (Ed.), Governance - Regieren in komplexen Regelsystemen. Eine Einführung (pp. 11-28). Wiesbaden: VS Springer Verlag.

Benz, A., Lütz, S., Schimank, U., \& Simonis, G. (2007). Handbuch Governance. Theoretische Grundlagen und Empirische Anwendungsfelder. Wiesbaden: VS Verlag.

Buckley, P. J., Clegg, J., \& Tan, H. (2006). Cultural awareness in knowledge transfer to China - the role of Guanxi and Mianzi. Journal of World Business, 41(3), 275-288.

Dale, R. (2003). Globalisation, Europeanisation and the "competitiveness" Agenda: Implications for Education Policy in Europe. Paper presented to GENIE conference, Nicosia, Cyprus.

Dale, R. (2009). Contexts, constraints and resources in the development of European education space and European education policy. In R. Dale \& S. Robertson (Eds.), Globalisation and Europeanisation in Education (pp. 23-43). Oxford: Symposium Books.

Dale, R., Kazepov, Y., Rinne, R., \& Robertson, S. (2016). Scales, discourses and institutions in the governance of educational trajectories in Europe. In A. Walther, M. Parreira do Amaral, M. Cuconato, \& R. Dale (Eds.), Governance of Educational Trajectories in Europe: Pathways, Policy and Practice (pp. 55-74). London \& New York, NY: Bloomsbury Publishing.

Dale, R., \& Robertson, S. (2012). Towards a critical grammar of education policy movements. In G. Steiner-Khamsi \& F. Waldow (Eds.), World Yearbook of Education: Policy Borrowing and Lending in Education (pp. 21-40). London \& New York, NY: Routledge. 


\section{Risto Rinne et al.}

Fenwick, T., Mangez, E., \& Ozga,J. (2014). Governing knowledge: Comparison, knowledgebased technologies and expertise in the regulation of education. In T. Fenwick, E. Mangez, \& J. Ozga (Eds.), Governing Knowledge. World Yearbook of Education 2014 (pp. 3-10). London \& New York, NY: Routledge.

Green, A. (1999). Education and globalization in Europe and East Asia: Convergent and divergent trends. Journal of Education Policy, 14(1), 55-71.

Han, S., \& Ye, F. (2017). China's education policy-making: A policy network perspective. Journal of Education Policy, 32(4), 389-413.

Jessop, B. (2002). The Future of the Capitalist State. Cambridge: Polity Press.

Junemann, C., Ball, S. J., \& Santori, D. (2016). Joined-up policy: Network connectivity and global education governance. In K. Mundy, A. Green, B. Lingard, \& A. Verger (Eds.), The Handbook of Global Education Policy (pp. 535-553). Chichester: John Wiley \& Sons.

Kandel, I. J. (1938). Problems of the University in Modern Society. The Educational Forum, $3,29$.

Kauko, J., Centeno, V. G., Candido, H., Shiroma, E., \& Klutas, A. (2016). The emergence of quality assessment in Brazilian basic education. European Educational Research Journal, 15(5), 558-579.

Kwiek, M. (2006). The University and the State: A Study Into Global Transformations. Frankfurt am Main: Peter Lang.

Lawn, M., \& Normand, R. (2014). Shaping of European Education: Interdisciplinary Approaches. London \& New York, NY: Routledge.

Lawn, M., \& Segerholm, C. (2011). Europe through experts and technologies. In J. Ozga, P. Dahler-Larsen, C. Segerholm, \& H. Simola (Eds.), Fabricating Quality in Education. Data and Governance in Europe (pp. 32-46). London \& New York, NY: Routledge.

Le Galès, P. (2004). Gouvernance. In L. Bousssaguet, S. Jacquot, \& P. Ravinet (Eds.), Dictionnaire des politiques publiques (pp. 242-250). Paris: Presses de Sciences Po.

Legge, J. (1983). The great learning, the doctrine of the mean, Confucius analects, the words of Mencius. Beijing: Foreign Languages.

Liu, Y. (2016). Origins of meritocracy in China. In Higher Education, Meritocracy and Inequality in China (pp. 11-34). Singapore: Springer.

Loncle, P., Parreira do Amaral, M., \& Dale, R. (2015). Introduction. In M. Parreira do Amaral, R. Dale, \& P. Loncle (Eds.), Shaping the Futures of Young Europeans: Education Governance in Eight European Countries (pp. 7-22). Oxford: Symposium Books.

Mayntz, R. (2004). Governance im modernen Staat [Governance in the modern state]. In A. Benz (Ed.), Governance - Regieren in komplexen Regelsystemen. Eine Einführung (pp. 65-76). Wiesbaden: VS-Verlag.

Mayntz, R. (2006). From government to governance: Political steering in modern societies. In D. Scheer \& F. Rubik (Eds.), Governance of Integrated Product Policy (pp. 18-24). Sheffield: Greenleaf Publishing.

National Planning Office of Philosophy and Social Science. (2011). Announcement of Education Projects Funded by NPOPSS. Retrieved from www.npopss-cn.gov.cn/GB/219468/ 15299041.html

National Planning Office of Philosophy and Social Science. (2016). Announcement of Education Projects Funded by NPOPSS. Retrieved from www.npopss-cn.gov.cn/n1/2015/1216/ c219469-27934440.html

Normand, R. (2017). Policy learning and expertise in European education. In R. Normand \& J-L. Derouet (Eds.), A European politics of education. Perspectives From Sociology, Policy Studies and Politics (pp. 73-91). London \& New York, NY: Routledge. 
Ozga, J. (2011). Researching the powerful: Seeking knowledge about policy. European Educational Research Journal, 10(2), 218-224.

Ozga, J. (2015). Working knowledge: Data, expertise and inspection in the governing of education. In H-G. Kotthoff \& E. Klerides (Eds.), Governing Educational Spaces - Knowledge, Teaching, and Learning in Transition (pp. 15-34). Rotterdam: Sense Publishers.

Ozga, J., Dahler-Larsen, P., \& Segerholm, C. (2011). Europe in translation. In J. Ozga, P. Dahler-Larsen, C. Segerholm, \& H. Simola (Eds.), Fabricating Quality in Education. Data and Governance in Europe (pp. 76-82). London \& New York, NY: Routledge.

Pal, L. A. (1997). Virtual Policy Networks: The Internet as a Model of Contemporary Governance? Proceedings of ISOC. Retrieved November 25, 2015, from www.isoc.org/inet97/pro ceedings/G7/G7_1.HTM

Park, S. H., \& Luo, Y. (2001). Guanxi and organizational dynamics: Organizational networking in Chinese firms. Strategic Management Journal, 22(5), 455-477.

Parreira do Amaral, M., \& Rinne, R. (2015). Reading discourses in the governance of educational trajectories of youth in Europe. In M. Parreira do Amaral, R. Dale, \& P. Loncle (Eds.), Shaping the Futures of Young Europeans - Education Governance in Eight European Countries (pp. 67-86). Oxford: Symposium Books.

Piattoeva, N., \& Gurova, G. (2018). Domesticating international assessments in Russia: Historical grievances, national values, scientific rationality and education modernization. In C. Alarcón \& M. Lawn (Eds.), Assessment Cultures: Historical Perspectives (pp. 87-110). Frankfurt am Main: Peter Lang.

Pons, X., \& van Zanten, A. (2007). Knowledge Circulation, Regulation and Governance. Literature Review (Part 6). Louvain: EU Research Project, Knowledge and Policy in Education and Health Sectors (KNOW\&POL).

Power, M. (1999). The Audit Society: Rituals of Verification. Oxford: Oxford University Press.

Power, M. (2003). Evaluating the audit explosion. Law \& Policy, 25(3), 185-203.

Rinne, R. (2001). Koulutuspolitiikan käänne ja nuorten syrjäytyminen [Cuff of education policy and the social exclusion of adolescents]. In A. Jauhiainen, R. Rinne, \& J. Tähtinen (Eds.), Koulutuspolitiikka Suomessa ja ylikansalliset mallit [Education policy in Finland and global models] (Vol. 1, pp. 91-138). Jyväskylä: Finnish Educational Research Association: Research in Educational Sciences.

Rinne, R., \& Ozga, J. (2011). Europe and the global: The role of the OECD in education politics. In J. Ozga, P. Dahler-Larsen, C. Segerholm, \& H. Simola (Eds.), Fabricating Quality in Education. Data and Governance in Europe (pp. 66-75). London \& New York, NY: Routledge.

Rinne, R., \& Ozga, J. (2013). The OECD and the global re-regulation of teachers' work: Knowledge-based regulation tools and teachers in Finland and England. In T. Seddon \& J. S. Levin (Eds.), Educators, Professionalism and Politics: Global Transitions, National Spaces and Professional Projects. World Yearbook of Education 2013 (pp. 97-116). London \& New York, NY: Routledge.

Robertson, S., \& Verger, A. (2012). Governing education through public private partnerships. In S.L. Robertson, K. Mundy, A. Verger, \& F. Menashy (Eds.), Public Private Partnerships in Education: New Actors and Modes of Governance in a Globalizing World (pp. 21-42). Cheltenham: Edward Elgar.

Rose, N. (1999). Powers of Freedom: Reframing Political Thought. Cambridge: Cambridge University Press.

Rose, N., \& Miller, P. (1992). Political power beyond the state. British Journal of Sociology, 43, 173-205. 


\section{Risto Rinne et al.}

Rosenau, J. (1999). Towards an ontology for global governance. In M. Hewson \& T. Sinclair (Eds.), Approaches to Global Governance Theory. Albany: State University of New York Press.

Rosenau, J. (2005). Global governance as disaggregated complexity. In A. D. Ba \& M. J. Hoffman (Eds.), Contending Perspectives on Global Governance: Coherence, Contestation and World Order. London: Routledge.

Sassen, S. (2010). "The global inside the national: A research agenda for sociology." Sociopedia.isa, online at: www.isa-sociology.org. In T. Fenwick, E. Mangez, \& J. Ozga (Eds.), Governing Knowledge. Comparison, Knowledge-Based Technologies and Expertise in the Regulation of Education. World Yearbook of Education 2014 (pp. 3-10). London \& New York, NY: Routledge.

Schuppert, G. F. (2006). Governance im Spiegel der Wissenschaftsdisziplinen. In G. F. Schuppert (Ed.), Governance Forschung. Vergewisserung über Stand und Ent-wicklungslinien (pp. 371-469). Baden Baden: Nomos.

Simola, H., Ozga, J., Segerholm, C., Varjo, J., \& Andersen, V. N. (2011). Governing by numbers. In J. Ozga, P. Dahler-Larsen, C. Segerholm, \& H. Simola (Eds.), Fabricating Quality in Education: Data and Governance in Europe (pp. 96-106). London \& New York, NY: Routledge.

Verger, A., Lubienski, C., \& Steiner-Khamsi, G. (2016). The emergence and structuring of the global education industry: Towards an analytical framework. In A. Verger, C. Lubienski, \& G. Steiner-Khamsi (Eds.), The Global Education Industry. World Yearbook of Education 2016 (pp. 3-24). London \& New York, NY: Routledge.

Weible, C. M. (2008). Expert-based information and policy subsystems: A review and synthesis. Policy Studies Journal, 36(4), 615-635.

Weiss, C. (1979). The many meanings of research utilization. Public Administration Review, 39(5), 426-431.

Weiss, L. (1997). Globalisation and the myth of the powerless state. New Left Review, 225, 3-27.

Williamson, B. (2012). Centrifugal schooling: Third sector policy networks and the reassembling of education policy in England. Journal of Education Policy, 27(6), 775-794.

Williamson, B. (2014). New governing experts in education: Self-learning software, policy labs and transactional pedagogies. In T. Fenwick, E. Mangez, \& J. Ozga (Eds.), Governing Knowledge. Comparison, Knowledge-Based Technologies and Expertise in the Regulation of Education. World Yearbook of Education 2014 (pp. 218-231). London \& New York, NY: Routledge.

Wong, Y.H., \& Tam,J. L. (2000). Mapping relationships in China: Guanxi dynamic approach. Journal of Business \& Industrial Marketing, 15(1), 57-70.

Yao, X. (2000). An Introduction to Confucianism. Cambridge: Cambridge University Press.

Zhou, X., Suominen, O., Fan, Y., Kallo, J., \& Rinne, R. (submitted). Reforms of Education Inspection in China from 1978-2015. 


\title{
6 Governance by data circulation? The production, availability, and use of national large-scale assessment data
}

\author{
Nelli Piattoeva, Vera Gorodski Centeno, \\ Olli Suominen, and Risto Rinne
}

\section{Introduction}

Education quality represents a key discursive justification for diverse ongoing education reforms. Using data as a tool of governance (Rose \& Miller 1992), quality assurance and evaluation (QAE) is a tool for attempting to reinforce central control at a distance while allocating more autonomy to local actors and simultaneously creating a need for and reliance on new experts and data infrastructures (Lawn \& Segerholm 2011). Governance at a distance relies on the provision and translation of information about subjects, objects, and processes to the centres of calculation and power (Hansen \& Flyverbom 2014). In this form, the new architecture of governance relies on data production and circulation (Ball 2016).

This chapter starts from the premise that contemporary education governance increasingly depends on and utilises quantitative data. However, paraphrasing Beer (2016), our assumption is that it is in the circulation of the outputs of measurement systems that we may see the unevenness and adaptability of governance at a distance through data, revealing something about the variations and messiness of the realities of the broader political orders to which data may belong. As Beer (2016) writes, frictionless data circulation is an ideal which often remains unfulfilled because of context-specific blockages and frustrations. In this chapter, we investigate what we term "the intended political project of data", that is, how education policy documents and statements by officials depict where data is supposed to circulate, for what purposes, and how. We then look at whether data circulation meets its claimed goals and aspiration by analysing data production, data availability, and data use as distinct but very intertwined phases of overall data circulation. In following the scholarly appeal to study actual rather than assumed processes of governance by data (e.g., Selwyn 2016), this orientation advances one of the main issues raised in Chapter 1 and elaborated throughout the book, namely, the difficulty of policy-planning and the unrealistic promises made in the name of QAE instruments. In doing this, we follow the book's abductive methodological premises to assist in teasing out the complex web of possibilities and limitations which exist in conducting (new forms of) governance. We thus treat governance attempts as potentially 
incomplete and riddled with tensions and unfulfilled expectations and seek to understand existing governance at a distance better and in greater detail.

Brazil, China, and Russia have entered the era of education governance by data differently and at different moments, bearing somewhat different legacies of the link between knowledge and decision-making (see Chapter 3). We focus our analysis on data produced through one type of National Large-Scale Assessment (NLSA) in each country: the SAEB (the Evaluation System of Basic Education) in Brazil, the assessments conducted by the NAEQ (the National Assessment of Education Quality) in China, and the USE (the Unified State Exam) in Russia. Despite differences in the formats of these three assessments (see Chapter 7), their comparative analysis is compelling because they share three important criteria. First, they represent crucial sources of information for national policymaking; second, they are produced and used as quality evaluation tools; and third, they aim to make data comparable across space (among selfgoverning sub-national units in Brazil, semi-autonomous sub-national units in Russia, and regions with limited autonomy in China) and time (to determine changes in learning outcomes). The chapter opens with a theoretical note to problematise data circulation as a tool of governance. We utilise the term "data circulation" to argue that circulation unfolds through distinct but interlinked phases of data production, availability, and use. We see all these phases playing a role in the prospects of governance at a distance by data. The chapter then moves to our research's empirical findings, which first address the intended political project of data and then the production, availability, and use of data explored under the respective sub-titles. The section on the intended political project of data uses official policy documents and interviews as empirical evidence, while the three subsequent sections rely mostly on individual interviews with officials and assessment experts.

\section{Governance at a distance through data circulation}

Scholars use the concept of governance at a distance to refer to modes of governance in which formal prescription is complexly absent, indirect, or enmeshed with more or less voluntary commitment to accountability, that is, to the submission of organisations and individuals to external performance measurement, which is often combined with (self)-evaluation (Rinne \& Ozga 2011: p. 66). It relies on those at the centre having information about distant persons and events (Miller \& Rose 1990). The concept of governance at a distance thus emphasises how the behaviour of governed actors is directed by the processes of collection and use of information by the authorities, who seek to direct the actions and behaviour of those targeted by these data. However, this form of governance does not replace but complements what might be seen as traditional governance, which has primarily relied on direct prescription (legislation and hierarchical principles absorbed in rules and procedures; see Maroy 2009). Various governance styles can therefore be integrated within the governance continuum. Researchers thus see governance at a distance as 
reconciling "decentralized action (subsidiarity, self-responsibility) with centralized assessment (standardization) to facilitate exchange and valuation in vast spaces and to make long distance control something the actors aim to achieve by pursuing their interests" (Rottenburg \& Engle Merry 2015: p. 22).

Effective governance at a distance necessitates calculations in one place to be linked to actions in another not through direct imposition but through assembling and connecting different actors and agencies in a functioning network. These actors, however, may often evince diverse, if not opposite, perceptions of and interests in data, reflecting the heterogeneous background networks which constitute them. These heterogeneous actors can represent both "producers" and "users" of data. To name a few, they comprise the commercial industry which produces software and hardware; the highly complex scientific expertise which enables the construction of test items and data analysis; policymakers who shape the demand for data and its application and set the necessary legislation which frames data collection, analysis, and use; and the multiple data audiences expected to use but which often also need to produce data (for example, teachers or officials who first collect data and then use its interpretations for various purposes). Government agencies, consultants, auditors, NGOs, and ICT personnel, among others, thus need to both supply and apply data to generate and consolidate networks as the means and channels of education governance (see also Hansen \& Mühlen-Schulte 2012; Piattoeva 2015, 2016; Hartong 2016).

We use the notion of circulation to describe how data such as the NLSA needs to become integrated in practices, decisions, and processes (Beer 2016). Otherwise, data cannot govern (Grek et al.2011). In other words, the power of measurements is located "not just in what they record or calculate, but in what then happens to those numbers, how they are used and by whom" (Beer 2016: p. 78). Three elements are thus of major importance in data circulation analysis: data production, data availability, and data use. Those who order and produce data contribute to defining policy problems and solutions; they frame the complex production chains and the horizon of policy interpretation when data are transformed into knowledge. However, researchers emphasise the role of the actual availability of data (Souto-Otero \& Beneito-Montagut 2016). Data should be made accessible to and used by policymakers for evidence - based policy and as "a political strategy to make the policy process seem less political and more rational" (Steiner-Khamsi 2016: p. 585). Data also need to circulate widely across governmental-administrative levels and among different state and non-state actors to direct action (Piattoeva 2015). Specifically, they need to be employed by local governments and in schools to influence curricula and pedagogy through teachers' and the local administration's data usage (for this aspect see Chapter 8).

The circulation of numbers can enhance their legitimacy and power if they move and accumulate new networks of constituents, technologies, and things (Espeland \& Sauder 2012: p. 86). The importance of data circulation has led researchers to call for a new sociology of numbers and quantification of 
education which considers how numbers are "mobilized, circulated, consumed and contested" (Gorur 2015: p. 13). The flexibility, stability, and combinability of numbers, in contrast to the written or spoken word, are said to enable them to transcend contexts and find governmental roles in new institutions and often for other than their original purposes (see Rose \& Miller 1992; Lascoumes \& Le Galès 2007; Hansen \& Mühlen-Schulte 2012). By examining the professed political project of data circulation and then looking at the actual production, availability, and use of NLSA data across the three national contexts, this chapter contributes to such a sociology of numbers in education, especially the debates about actual governance at a distance through data and the realities of evidence-based policy and QAE tools.

\section{The political project of data circulation in Brazil, China, and Russia}

Brazilian politics has historically favoured political decentralisation in education, while constantly projecting the construction of a coherent nationwide education system (see Chapter 3). The 1990s reforms deepened administrative, financial, and pedagogical decentralisation and motivated and justified numerical data as the main instrument for obtaining a national perspective of a disparate education system (see Kauko et al. 2016). According to the main national data expert body, the National Institute for Educational Studies and Research (INEP), NLSA data are intended to support policymaking and enable the monitoring of public policies at the three levels of government (municipal/state/ federal), with the main goal of "contributing to the improvement of education quality, equity and efficiency. Besides, [NLSAs] seek to offer data and indicators about [the] factors [which] influence pupils' achievements" (INEP, n.d.c).

NLSA data are assumed to circulate freely and widely in Brazil. They are considered public data: information which should be disclosed by the national provider and which may be freely used and reused, redistributed and re-appropriated without legal restriction. As an official from INEP put it, "[I]t is not reasonable here in Brazil, with our tradition, to say that you are not going to disclose that data" (BR-N-03). NLSA data are designed to "introduce information to the society" (BR-N-01) and "to produce clear and trustworthy information to managers, researchers, educators and the general public" (INEP, n.d.b). Besides this broad public aim, NLSA data are intended to circulate among policymakers working in both the executive and legislative federal branches, with the aim of informing education policies (INEP, n.d.b). NLSA data should also travel to sub-national units such as state and municipal governments, local councils, and schools (INEP, n.d.b). Interviewed policymakers and officials stated that NLSA data can and should trigger a vertical chain of reaction, resulting in improved teaching practices and education quality. As an official said,

[The INEP has] the task of collecting the information, and to handle that information and to render that information clear to the society. The 
ministry has the task of taking that information and orienting policies and handling policies ... The results that are produced here are often handled by teachers on television [the open broadcast TV School] ... and that helps teacher training, helps to work in the classroom ... There is an attempt to ensure that the teachers and directors should be able to use the results that come from these evaluations, that they are able to use [them] to change the teaching practice and the practice within the schools.

(BR-N-02)

Having closely followed international trends since the late 1970s, Chinese scholars started to raise concerns about the shortage of coherent and trustworthy data on the education system's performance. Against this backdrop, the Chinese NLSA, the assessments conducted by the National Assessment of Education Quality (NAEQ), was born. An interviewee explained,

[The NAEQ assessments were established] because there is no data. Because the data in Chinese education is largely a mess and there are many discrepancies. So, we need data from a place that we can trust. We need to get first-hand data.

(CN-E-02)

Although the system is still under development, the initial testing phase, which officially began in 2007, was phased out in 2015. Documents such as the Outline of China's National Plan for Medium and Long-term Education Reform and Development 2010-2020 (State Council of the People's Republic of China 2010) have elevated assessments to serve as the core element of the education system. The purpose of assessments is to understand the system better to implement evidence-based policy, which leads to qualitative improvements in education (Zhou et al. forthcoming). The previously mentioned reform plan for 2010-2020 (State Council 2010) also suggests that it is necessary to establish a national information database to develop the quality of education on the local level (see also Fan \& Liao 2013; Rasmussen \& Zou 2014; Zhang \& Wan 2017). Assessment reforms take place amidst broader attempts to diversify evaluation approaches and consequently reduce the number of exam and score-oriented practices. Although in the initial experimental phase, NLSA results have been distributed only within the government, the plan is to release all the results (but not the original data obtained through assessments, a difference which will be elaborated on later) to the general public to increase accountability (as of 2017 no fixed time frame has been set). As one of our interviewees asserted, "I think it [releasing the results to the public] serves a purpose. You shouldn't keep data a secret, but it should be published. Only in this manner can we have true accountability. Only then can it produce a marked effect" (CN-E-02).

The Russian USE (Unified State Examination) started as an obligatory graduation exam for upper secondary schools in 2009, but with growing political concern about the unsatisfactory quality of education, a variety of other uses 
were attached to it, including informing pedagogy, ensuring accountability, and monitoring education quality through the production of quantitative performance measurement data based on exam scores (see Luk'yanova 2012; Tyumeneva 2013; Piattoeva 2015). Because these developments transformed the USE into a very high-stakes examination for many stakeholders, Russian ministerial authorities have recently started to diversify national assessments to relieve pressure on USE results. However, at the time of the study, the USE remained the most important, as well as the longest existing, tool for education quality assessment, and it is entrenched in the Russian Law on Education.

The Russian state's education project is targeted at the unification and standardisation of the content and results of national school education. The discourse of "putting the state back in", meaning that the central authorities should have more say in the content of school education, is strong and widely supported by the authorities and public. National authorities also seek to establish an "effective state" system to increase the efficiency of federal regulation and local selfgovernance and bridge the gap between national policy and its implementation. However, as the implementation of national school policy is the responsibility of the municipalities and depends on their funding, disposition, and expertise, assessment data are expected to incentivise local policymakers, school administrations, and teachers to understand and target problems in learning achievements and introduce changes in line with national priorities. In this respect, the initiation of standardised testing runs in tandem with another central policy, the introduction of a more standardised, output-based curriculum model in Russia (Piattoeva 2015).

Government programmes for various public sectors, including education, embrace detailed, quantitatively articulated objectives and a system of numerical performance indicators to monitor the accomplishment of results annually. Following this, the results of the USE can be employed as objective performance and quality indicators, for example, in monitoring the quality of higher education or the efficiency of local authorities (Piattoeva 2015). Objectivity is defined as using standardised, expert-developed evaluation tools as sources of impartial information on the functioning of education. Alongside objectivity, the ideal of comparability is an underlying value and political goal of the initiatives linked with the USE. Comparability is expected to function on different levels: teachers compare their students' results and simultaneously examine the results of other teachers and students in their city, region, or country, and the regional comparability sought at the national level (by Rosobrnadzor - the National Agency for Control and Supervision in Education, for example). Teachers are held accountable for learning outcomes measured by standardised assessments, and the recent introduction of bonuses and "effective contracts" has intensified this trend. Teachers' informed professional judgement is highly mistrusted because, it is argued, it is either arbitrary or biased and incommensurable beyond its context, and "those who produce the results should not be put in a position to evaluate them" (Civic Chamber of the Russian Federation 2014). 
In this section, we have explored the justifications and objectives for the NLSA in the three contexts, which illuminate, in CADEP's terminology, the discursive context (political possibilities) within which NLSA data emerge and circulate as a tool of governance at a distance. Our analysis makes clear that the countries share a discursive space, and all aspire for NLSA data to play a significant role in achieving: 1) the production of evidence for better policy and better understanding of the state of education in the country; 2) the closing of the policy implementation gap - a goal mainly linked to the vastness and internal heterogeneity of the countries and, in the cases of Brazil and Russia, to their nature as federal states with substantial autonomies delegated to the sub-national level; and 3) the management of education quality (with quality bearing a slightly different connotation in each case: see Minina et al. 2018). This analysis affords an important background to our exploration by characterising the discursive context and the national policies to which NLSA data are expected to contribute in the three country contexts. In what follows, we explore the actual NLSA data circulation.

\section{The uncertainties of data production}

In Russia, the production of the USE is centralised, being tightly controlled by Rosobrnadzor and the technical and analytical units functioning under it (for example, the Federal Institute of Pedagogical Measurement in charge of developing test items and analysing test scores, and the Federal Testing Centre responsible for infrastructure - the distribution and collection of test packages). However, local actors like regional information centres are responsible for the enactment of exams in strict accordance with national legislation, and non-multiple-choice tests are marked by groups of subject specialists usually composed of teachers. The national authorities seek to standardise and control data collection procedures to the greatest possible extent (through strict and detailed legislation and observation, training, and harsh penalties for rule violation), while still failing to ensure maximum compliance (see Piattoeva 2016). Thus, the quality of the NLSA is a constant focus of political and academic discussion, largely because data are inevitably produced by and rely on multiple actors with different stakes, and data are therefore expected to play too many essentially incompatible roles.

Problems are caused by the conflicting demands for the USE to become a nationwide standardised examination, a tool of accountability, and a source of impartial policy - relevant knowledge. In the general climate of increased control of the functioning and results of school education in general and assessments in particular (Piattoeva 2016; Gurova \& Piattoeva forthcoming), even attempts to produce information on the exigencies of the education system are reinterpreted and diverted to the discourse of control:

There are no groups, except for external experts, who would be interested in objective results. For instance, I would be interested in looking at them. 
But for that we need to refrain from using them for evaluation because now the USE carries too many burdens, that is, it is the graduation certificate, entrance examination to higher education, and in addition it assesses everything possible starting from the teacher.

In China, the NAEQ assessments are only starting to take root, and the people involved still have little experience of their implementation. Our evidence on the topic is therefore limited, especially concerning the actual use of assessment data. Nevertheless, our limited research material communicates that there is a strong perception of assessment data's fragility. Assessments are expected to counter the practice of using school examination results as the primary indicator of quality in education (Rasmussen \& Zou 2014), stressing the importance of providing timely feedback to different stakeholders based on assessment data. However, there is a substantial fear among scholars and politicians that new assessments may become another high-stakes examination because of China's century-long history of defining education quality in terms of examination excellence. The fear is that results will no longer capture the reality, that is, the measured and assessed variables. An interviewee explained,

We don't want like the schools or students [to] take it as another examination. .. . [I]f they think ... they will rank us, then they will do some reactions, yeah. You know that ... right now ... we get the true answers from students. Like I don't have one hour for my outdoor activities . . . but later if you take it as high-stake, I am not quite sure they will answer no. Maybe the teachers will teach them only to answer yes.

(CN-E-01)

The Brazilian academic community frequently contests the methodological and political choices underlying the design of the Evaluation System of Basic Education (SAEB), maintaining that the SAEB does not enable the identification of schools' impact on pupils' learning achievements (for a review of the literature see Candido et al. submitted). However, our interview material reveals that the INEP's technical capacity to produce data is rarely contested. It is rather the capacity of the SAEB to account for the reality of Brazilian education and influence education planning at different levels which is challenged. Whereas policymakers, civil servants, evaluation experts, and technicians at the three levels of government generally stress the necessity of a national standardised evaluation to achieve education quality, many scholars and practitioners question the suitability of quantitative national standardised approaches to assess or make sense of educational realities. They consider the Brazilian education system too complex to be measured by quantitative indicators, which they characterise as superficial. For example, some interviewees raised questions about the significance and method of evaluation by contending its irrelevance either for daily school life or Brazilian education as a whole: 
[T] he pertinence between what is required in these assessments or evaluation systems, as is the case with the SAEB, and the relationship they have with what in fact takes place in the daily life of Brazilian education classrooms, that's a question that still needs to be better explored in the country.

(BR-E-02)

While views diverge concerning the content the SAEB should measure and the SAEB itself as an evaluation tool, there is agreement on the inherent logistical challenges of data production in such a large and diverse country. The production of SAEB data is centralised. The INEP is responsible for the design of the SAEB, although scholars, experts, and teachers are engaged to work on content. The INEP hires private companies to collect data and provide certain analyses, the results of which are crosschecked with the INEP's to confirm data validity. The INEP works directly with one key person in each State Secretariat for Education, whose perceptions about the SAEB and degree of involvement in the process seem to affect the smoothness of data collection and the subsequent application of results. However, data production remains challenging in a country where the main NLSA covers 58,000 public schools and 4,000,000 pupils (INEP 2016). The time lapse between data collection, analysis, and dissemination does not allow for an in-depth treatment of data because, as an INEP official puts it, "[W] hen you [have] to publish the result, many times you are already engaged in another process on another [assessment] to start again" (BR-N-07).

Quantification relies on a series of interpretative decisions about what to quantify and how to categorise and label it (see e.g., Desrosières 1998). Previous research argues that antithetical attitudes towards data usually emanate from high degrees of negotiation of validity and reliability and the tensions and dynamics which may be created by methods of data collection (Landahl \& Lundahl 2013: pp. 57-58). In our cases, these issues also easily conflict with data production and explain why actors do not always treat the NLSA as entirely objective, precise, or accurate, even when the technical side of producing quantitative assessments is little contested. In Brazil, criticisms of validity are especially tangible. In Russia and China, criticism of produced data focuses mainly on its reliability and emanates from a mistrust of data production processes. This mistrust is linked to political contexts in which data carry high stakes and there are historically specific assumptions about the meaning and role of external evaluation.

\section{The ambiguities of data availability}

In China, data generated directly by assessments are only available to the relevant NAEQ staff and to the highest levels of the Ministry of Education. Outside this circle of trust, the lower government units, the media, the public, and even external researchers - as our research team discovered as a result of a small misunderstanding in the project's early stages - are not allowed access to data. There is an evident fear that if such unfiltered data spread too far, control 
of them may be lost and the media will focus on naming and shaming, again reviving the high-stakes image of assessments which the government is trying to counteract. An interviewee explained,

In China there is this problem. That is, there is this peculiarity that if you publish [assessment] data, they [whoever has access to data] will start making mutual comparisons ... It might be that the consequence is that there will be rewards and punishments. But this will cause the objective of the evaluation to stray out of line.

(CN-E-06)

However, there are some minor exceptions to this rule. As mentioned, the assessment system has been developed by relying on foreign expertise. Thus, scholars and experts working at the NAEQ have sometimes consulted external experts to collaborate on assessment tools. In these cases, national experts can choose to provide outsiders with data. During our meeting, an interviewee reflected, "For example, I could use our data as an example for you today, but it's absolutely not fine for others to see it" (CN-E-02).

Despite restrictions of the availability of assessment data, the NAEQ provides ready feedback in the form of information or results to sub-national units. An interviewee working for the NAEQ stated, "[A]nother division [in the NAEQ] is our reporting ... division. They use our data to write reports for the governments" (CN-E-01). In practice, this means that the scores of a single school or the questionnaire answers of a single teacher cannot be extracted from results distributed to the sub-national governments. Instead, a county-level government, for example, will only receive information about average performances and results in their county and about the national average. They can therefore only make comparisons between their own performance and the national average or on a time axis by comparing their current and previous performances. However, there is some ambiguity concerning whether local governments will be allowed to distribute these results to whomever they wish. Moreover, in the currently available source material (publicly accessible documents, our interviews, and existing research), there is conflicting information regarding whether the school level receives any feedback. What is known is that individual students or teachers participating in assessments do not receive it. Again, the fear is that assessments will be treated as a high-stakes test. The Chinese authorities thus face a situation in which they seek a delicate balance concerning which assessment data and results are distributed and how. They fear that if they are spread too extensively, assessments will become a high-stakes test. An interviewee explained,

So, it [the feedback] is not for the individual. And we don't want them [the students] to get nervous about their individual score. . . [W] don't want [the assessment to be] taken as a high-stakes test . . If you report 
individuals, maybe ... the students will get nervous thinking how they are going to perform.

(CN-E-01)

In Russia, individual test scores of the results and participants of the USE are stored in the federal database. The users of the database are said to be all the interested federal and local authorities, educational institutions, and other organisations involved in the USE. The establishment of the databank, therefore, constitutes an unprecedented achievement - never has the federal state possessed comparative data of such geographical scope and detail (see Bakker 1999). However, evaluation experts argue that the data accessible for research are insufficient; the average scores available for public attention, for example, are far from being the research data they want or can work with analytically. Thus, actors who can perform a scientific analysis of assessment data as a precondition for informed political decisions are largely unable to complete the task because their access to data is limited:

The ministry and Rosobrnadzor are keen to accumulate all the information for themselves, which they receive from the [regional] centres of quality evaluation, from the regional departments and ministries, and it is very difficult for society to receive this information. For example, Russia took part in TALIS [the OECD's Teaching and Learning International Survey], you know ... So now in order to productively analyse TALIS data, we need the USE results of the schools that took part in TALIS. These are only two hundred from fourteen or fifteen regions. We cannot obtain this information. Can you imagine? We are the national coordinator, our institute is the operator of the project, we don't need this information for the purpose of publicising it in the newspapers ... We need to implement a comprehensive analysis of an international study. Big money was invested. Who is interested in the analysis? Who ordered the study? The ministry.

(RU-E-04)

Uncertainties concerning data availability surface as a struggle between the necessity to collect data for governance and the management of education quality and simultaneous realisation that production of performance data can easily weaken decision-makers' immunity and lead to calls for reverse accountability. As one Russian respondent eloquently commented, "No one is interested in receiving objective information." He continued that the ministry did not wish to see poor results because if poor performance data surfaced, the next question would be "What do we need the Ministry of Education for?" (RU-E-03). Yet assessment data are widely available in the form of crude average scores (of schools, regions, in a particular subject, and so on) as performance indicators employed by officials at different levels of education administration and in league tables supported by private and public actors. While 
authorities frequently state that schools or teachers should not be compared or ranked based on testing scores - at least not crudely, with no consideration of diverse contextual factors - no strong efforts are undertaken to deal with the practice. The national ministry's general message concerning this topic remains controversial, as the ministry itself has ordered and refers to league tables.

In Brazil, the situation is the reverse of that in China and Russia. Data dissemination is encouraged by the fact that the INEP produces a large amount of varied data, which scholars use extensively. The INEP provides a research service and space for consultants, teachers, and researchers to access INEP databases, the only criteria being that data are used for research or study and ethical principles are met. The INEP has also supported several initiatives to meet with other education actors to discuss the NLSA and other monitoring tools in the context of the National Educational Plan (e.g., INEP 2015). Furthermore, it recently created an online platform for teachers to provide them with direct and almost individualised pedagogical feedback (data are presented by schools and localities, pupils' proficiency levels, comparisons with similar schools in the region, and NLSA items and their pedagogical explanation; see INEP n.d.a).

Besides initiatives targeting the educational community and relevant political actors, the INEP makes data available to the wider public. It publicly disseminates the results of the SAEB, which consist of the mean mathematics and Portuguese literacy scores combined with several other variables. The INEP's website design and performance has recently been improved, and data are extensively available in several formats. Despite these recent developments, all the INEP interviewees acknowledged that data dissemination was the INEP's main challenge. Interviewees described INEP reports and databases as providing "arid" information which was difficult to understand and recognised that civil society organisations were the most important actors in helping with data availability and visibility. Even if these organisations frequently draw on data to push their own agendas (sometimes their policy proposals are aligned with the government's, sometimes not), their contribution to data dissemination is crucial. They are seen to have better communication strategies and display results in easily accessible, user-friendly ways. Indeed, local-level interviewees frequently referred to the QEdu platform, which is administered by a privately funded civil society organisation and extensively and interactively displays NLSA data.

In Brazil, data dissemination is vulnerable to pressure from every sector of society, including policymakers, the media, civil society organisations, and even school principals, wanting to advertise their place in the rankings (e.g., BR-N-02). The media diffuses them extensively. Whenever NLSAs take place, assessment processes are scrutinised, technical or procedural mistakes identified, and results used to support arguments, usually according to the speaker's political and education stances. Freely drawing on these results, various parallel polemical rankings are constructed. Politicians clearly try to channel dissemination according 
to the political agenda, and professional associations' and unions' engagement with data greatly contributes to their circulation.

Despite the shared discourse on rational decision-making and making data a prime tool of education governance at various levels, our cases demonstrate considerable differences in data availability, that is, who has access to assessment data, of what kind, and for what purpose. Here, as in the previous section, we see a pattern in which the realisation of shared policy is embedded in the casespecific institutional and discursive arrangements and particularities of sociohistorical dependencies, which can both enable and constrain actual data access.

\section{Too much or too little data, and who knows how to use them?}

All Brazilian interviewees acting nationally, and therefore involved - though differently - in national education politics, expressed the view that NLSA data have fuelled the debate on education quality. As a representative of a civil society organisation stated,

[B]y putting the discussion of the metrics based on a large-scale assessment you visualise within the education system the inequality [provided by the lack of quality] and therefore you make more tangible the talks and the formulations and actions about equality.

(BR-NNGO-05)

Despite this, the effects of NLSA data on national education policy are disputed. Several interviewees suggested, as is aptly systematised by a senior civil servant working at the Federal Senate, "the consolidation of the evaluation system [i.e., of the SAEB] has been an important driving force of public policies in education" (BR-N-11). Other interviewees suggested that the impact is still far from what it could and should be. NLSAs collect information which is not comprehensively used to formulate concrete education polices which might target the improvement of the school as a whole. For many, there is enough information to understand which aspects need to be improved in each school, but there is no consequential national political use of collected data.

Several INEP interviewees mentioned that at the state level many governments use data carefully in education planning. However, other national, state, and municipal interviewees mentioned that most state and municipal administrators had little capacity to use data: they were either unqualified to do this or they lacked resources. Even in the richer states data use seems to be in its early stages. An interviewee from the state level, for example, related that they were still trying to "create a culture of data usage", and that in most states NLSA data is still "less used than [...] it should be because there are no established competencies among the secretaries [of education] to know what to do with these results" (BR-S-01). 
Nevertheless, some richer states and municipalities have chosen to create their own assessments in the guise of preparation for NLSAs and local monitoring and only rhetorically react to national results. It is argued that NLSAs do not fully meet the needs or particularities of the states. However, many states and municipalities acknowledge severe financial implications and given the existence of the national system, mention only the need to complement it. This partial disengagement with NLSAs seems connected to an attempt to ensure that education responsibilities are not appropriated by the national government, which has used central control in steering certain education aspects, such as the establishment of a common curriculum. Although these initiatives are generally welcome, it is obvious that states and municipalities see their own assessments as a strategy to retain political authority over education issues.

While NLSA data met their target in informing education debates and, partly, at least, policymaking, they seemed to fail in influencing school practice as the political project foresaw. Historically, governmental actions, regardless of level, are the object of the education community's public mistrust. More specifically, mistrust of NLSAs emanates from accountability policies. Although neither the INEP nor the Ministry of Education supports data use for accountability purposes (interviewees were unanimous here), some states and municipalities use NLSA data to make schools accountable. Furthermore, teachers do not understand results and do not know how to engage with them. This has triggered the construction of the online platforms mentioned in the previous section, which aim to inform teachers by explaining NLSAs and translating data into classroom reality. However, because of the great number of teachers in Brazil and their diverse educational backgrounds, the link between data and classroom activities remains a major challenge. NLSA results are still far from being used to improve teaching and learning in Brazilian schools.

In China, utilisation of gathered data is considered a major problem, as practitioners do not always know how to interpret NLSA data and how to employ them in practical solutions. In this opaque context, policymakers sometimes choose the feedback that best supports their political agenda, and policy surfing means feedback is used to justify a predetermined policy choice rather than to identify problems for which policy solutions might then be sought. Once the NAEQ has analysed scores and the final assessment results are released, the NAEQ staff holds meetings with education officers, inspectors, and school principals from different provinces and municipalities. NAEQ experts suggest how to tackle problems identified by assessments. These meetings' emphasis is on cooperative action. An interviewee explained, "The key is in finding the problems and then helping schools by solving the problems together" (CN-E-07). Evaluation experts thus gain in power and become indispensable in helping to translate data into potential policy solutions and pedagogical tools. However, this also has its limits: feedback does not oblige the recipient to make any changes.

As previous research (Zhang \& Wan 2017) and our interviewees point out, the assessment system is a somewhat recent innovation. Data use is considered 
a major problem, the feedback system remains incomplete, and follow-ups are rare. Moreover, as our interviews frequently indicated, these new assessment practices and ideas are still largely emphasised only in official documents, whereas in practice, examinations still reign supreme as the primary quality indicator. Local practitioners do not always know how to produce solutions based on results of a new assessment, even when provided with suggestions. A scholar reflected on the general situation:

I think the challenge is ... how we can use the data well ... the results. So, I mean, we can do the national assessment. We can easily do all these things ... But most important [is] how we can use it ... We want to find a way to use results.

(CN-E-05)

Sometimes, there is almost an atmosphere of apathy and disinterest concerning assessments, because they are not always seen as helpful in solving local problems:

For example, tens of counties in Shandong and Henan provinces and in Jiangsu province each year receive national-level basic education quality monitoring [i.e., they take part in assessments], but they are ignorant of the results, and just take care of organising them.

(CN-E-13)

Interestingly, the fact that assessments are not used for ranking is partly to blame. An interviewee sarcastically noted,

Some people take it [the feedback] very seriously, but most people don't. Because in our education system they care about things that have to do with selection, and they are not too concerned about these things that have to do with quality monitoring. When would they care? If you used these results to compare, they would take notice!"

(CN-E-06)

A further challenge is that assessments reveal a significant amount of detailed information (teachers' work burden in one school was an example given by an interviewee) beyond levels to which feedback extends; feedback does not target the levels at which data were collected in the first place. It appears a compromise of sorts has been struck, whereby school principals are informed of a problem at a general level so they can attempt to address it themselves. An interviewee elaborated,

So they [the school principals] need to find the causes. But we usually we cannot go that deep for them. But we ... will ... say: 'Okay, this is the phenomenon we've discovered. Okay, this information we've got.'... We kind 
of give them a kind of a direction: 'Okay, this is the way you should go to try to find out the problem'.

(CN-E-01)

In Russia, interviewees often mentioned a conflict between the demand for evidence-based decisions on the one hand and the fast pace of performance evaluation on the other. National-level civil servants criticised local administrations for their lack of intellectual investment in the decisions that would bear fruit, and their preference for quick fixes (such as dismissal of personnel).

There are two negative aspects in managerial competences. First, nonintellectual reaction, when a head sees a ranking position and says "punish the bad ones and reward the good ones" ... And second, making decisions without analysing the causes of problems, or without the adequate resources.

(RU-O-04)

At the same time, the support provided at the national level to improve managerial resources was often limited to simply channelling more data, especially comparisons between different regions' achievements. Analytical support was thus supplanted by an increase in the volumes of data distributed during internal meetings between the national ministry and regional authorities, for example.

National experts questioned officials' capacity to work with data and whether data were used for rational decision-making instead of heavy control or onesided reporting.

The civil servants have no time to pause and think. They work at a very fast pace. And if [s/he] didn't have the required competences to start with, it is pointless to hope they will develop.

(RU-E-03)

Russian interviewees often complained about the expansion of reporting at different governance levels, meaning that, in addition to NLSAs, schools and regional authorities spent progressively more time on collecting and channelling different types of statistical and other information requested and processed by higher levels. Interviewees expressed a somewhat contradictory position about the simultaneous abundance and shortage of data. Many mentioned that data were of the wrong kind. As we discussed earlier, high-stakes data cannot be trusted fully even when they are available because data lack the contextual information needed for a deeper academic analysis. The difficulty and high cost of data collection were also mentioned. In this respect, experts compared Russian NLSA data to international large-scale assessments and praised the latter for their richness, openness, and depth.

Concrete understanding of management and data use is still in the making. Some policymakers admit that data cannot be used on their own and that 
common sense is still needed in decision-making processes, acknowledging the limitations of data such as the problems caused by high stakes and the complexity of learning outcomes on which the NLSA is intended to reflect (e.g., RU-O-05). However, some individual and still rare examples of concrete data use in the decision-making process were reported, for example, targeted training in Russian language teaching for regions where Russian is the second language, as well as the decision to divide the USE mathematics test into basic and advanced levels, reflecting the status of the USE as a graduation exam and its recognition of the different needs of students in further education (e.g., RU-O-05). Surprisingly, despite the frequently cited lack of resources, time, or possibility to analyse available data and use it meaningfully for evidence-based policy, the motivation to produce more data has remained strong:

When we receive a set of information on the state of affairs, then in a good sense we always have requests for further development. For example, when we get a snapshot, we want to see dynamics. When we receive dynamics, we want to see the added growth, individual progress. When we know the individual progress in maths, for example, we want to have an idea about the individual progress in thinking ... And second, [data] should be used for decision-making. I want to emphasise again that between data and decisions there is a space in the form of the manager's head, which is regularly missing.

(RU-O-04)

The idea behind evidence-based policy is that the more information policymakers collect, and the faster they collect it, the more informed decisions they will be able to make and, thus, the more effective the management of social problems will be (Tsoukas 1997). However, this section problematises this image of evidence-based policy and points to the complexities of putting quantified education data to work in education realities, whether at the policymaking level or in regions, schools, and classrooms.

\section{Conclusion}

Our comparative analysis of the three national cases has explored the diverse ways by which data are intended, but often fail or only partly succeed, to be integrated in education governance practices at a distance. The political project of QAE in general and the NLSA in particular in Brazil, China, and Russia envisions NLSA data providing a better general view of the education systems of these enormous and heterogeneous countries and a more nuanced view of learning achievement at the student, teacher, and school levels, thus optimistically and at least rhetorically incorporating very diverse stakeholders in the data project. In reality, data are not easily integrated in these actors' practices, limiting their capacity to govern at a distance. Echoing our other chapters, the variation and friction the chapter describes reflect the specific political situations 
and possibilities embedded in the socio-political and historical contexts of these countries, such as the various country-specific reforms in education and beyond. In Brazil, for example, the strongly democratic open and multi-vocal policymaking agenda provides a platform to make performance data fully available - a discursive feature absent in China and Russia. Restrictions on data availability in China and Russia reflect different contextual factors. They emanate from synoptic data possibilities, because in one case governance at a distance afforded by data comes at the potential cost of making people in political power visible (see Landahl \& Lundahl 2013). In another case, there is a fear that publicly available data may cease to reflect educational reality 'objectively'. Thus, in contrast to Brazil, NLSA data in China and Russia are guarded and used exclusively by national officials. Our interviews with civil servants and evaluation experts often signalled ambiguity and scepticism regarding data analysis and use even within official circles. Moreover, restricting data to official usage has negative consequences for the overall project of evidence-based policymaking, as academic experts may also be excluded from the data sources necessary for a scientifically sound analysis.

In all cases, we have detected concern about data objectivity, especially the reliability of data collection, which is inevitably performed by actors who are more or less external to the evaluation agencies. Data production is problematic either because it is conducted by locals with varying degrees of professional interest in and commitment to the process or because it is generated by actors who are then evaluated based on these data. Fragility of trust in the processes of data collection is compounded by mistrust of the officials and experts involved in administering and interpreting assessments and the tensions between experts and officials at different levels of governance and between representatives of national and sub-national education administration. These complications weaken data, paving the way for further mistrust and criticism. Quantification thus highlights the important role of trust between civil servants and assessment experts because of the civil servants' reliance on the technical and analytical capacity of the experts (see the case of Russia especially). Our analysis equally points to the importance of a working relationship between the national and sub-national administration levels, especially because of the national level's reliance on the willingness and possibilities of local actors to engage with the NLSA. This relationship seems deeply distrustful, rooted in controversies concerning NLSA use as data for both evidence-based policy and accountability, as well as attempts to partly recentralise certain features of the education system by means of NLSA data (especially in Brazil).

While smooth governance at a distance through data is envisaged because of the assumed easy circulation of numerical data, circulation is contingent on the successful abstraction and de-contextualisation which allow new meanings to be attached to data when they are produced for a delimited purpose (Porter 1994). Complete or partial failure to achieve an accepted abstraction and de-contextualisation impairs or alters the proliferation of networked actors 
and constellations of new relationships, undermining successful governance by data. The simplification of complexity presents an argument against NLSA data which is difficult to refute, and various actor segments may make accusations of reductionism at any time. As the case of Brazil shows, this kind of criticism is made more easily the more data are made publicly available to diverse groups of actors. Thus, paradoxically, while data should be made accessible if they are to be integrated in diverse practices to influence others' conduct, wider availability increases the possibility of questioning data and the diversion of original governance intention. In summary, whereas NLSA data are frequently argued to offer solid evidence, our study shows that NLSA data can be easily dismissed even for mutually controversial reasons. It is either described as too rigid to capture complex realities or as too subjective and unreliable to be trusted as an accurate and detached description.

These frictions occur during different data circulation stages and give rise to a situation which is characterised not by more data use and reflexivity but by the intensification of data production, thus ultimately accentuating a particular phase of data circulation. Contrary to David Beer (2016), quoted in this chapter's introduction, Anna Tsing (2005) describes friction as essential for motion: friction is productive and enabling. Inspired by this alternative perspective, we conclude that while data circulation and thus governance by data do not function as a well-oiled machine, friction does not slow processes down but instead bears a productive power to retune them in new ways. However, as friction emanates from historical trajectories and the particularities of political and discursive contexts, unexpected directions are neither random nor open to any possibility. In our cases, we especially emphasise the politically and historically charged dynamics of trust and mistrust in the possibilities of NLSA data, linked to the complicated relationships of trust and mistrust between and among different actors. This situation occurs both nationally and locally and between levels and leads to the intensification of data production. For example, in Brazil, local actors produce new data to both prepare for the NLSA and generate data more suited to local needs. In Russia and China, data production is stimulated by problems of data reliability and objectivity.

\section{Bibliography}

Bakker, S. A. (1999). Educational assessment in the Russian federation. Assessment in Education: Principles, Policy \& Practice, 6(2), 291-303.

Ball, S. (2016). Following policy: Networks, network ethnography and education policy mobilities. Journal of Education Policy, 31(5), 549-566.

Beer, D. (2016). Metric Power. London: Palgrave Macmillan.

Candido, D. H. H., Kauko, J., \& Centeno, G. V. (submitted). Portraying quality assurance and evaluation in Brazil: An analysis of how quality is problematized in Brazilian basic education.

Centeno, G. V., Kauko, J., \& Candido, D. H. H. (2017). Quality assurance and evaluation through Brazilian lenses: An exploration into the validity of umbrella concepts. Comparative Education 54(2), 132-158. 


\section{Nelli Piattoeva et al.}

Civic Chamber of the Russian Federation. (2014). USE Shifts to Independent Rails. Retrieved May 6, 2015, from www.oprf.ru/ru/print_datas/26091 [in Russian].

Desrosières, A. (1998). The Politics of Large Numbers: A History of Statistical Reasoning. Cambridge, MA: Harvard University Press.

Espeland, W. N., \& Sauder, M. (2012). The dynamism of indicators. In K. E. Davis, A. Fisher, B. Kingsbury, \& S. E. Merry (Eds.), Governance by Indicators (pp. 86-109). Oxford: Oxford University Press.

Fan, Y., \& Liao, Q. (2013). 基础教育质量监测:国际经验与本土路向 [Basic education quality monitoring: International experiences and the local path], 教育导刊, 4, 37-40.

Gorur, R. (2015). Assembling a sociology of numbers. In M. Hamilton, B. Maddox, \& C. Addey (Eds.), Literacy as Numbers - Researching the Politics and Practices of International Literacy Assessment (pp. 1-16). London: Cambridge University Press.

Grek, S., Lawn, M., Lingard, B., Ozga, J., Rinne, R., Segerholm, C., \& Simola, H. (2011). National policy brokering and the construction of the European education space in England, Sweden, Finland and Scotland. In J. Ozga, P. Dahler-Larsen, C. Segerholm, \& H. Simola (Eds.), Fabricating Quality in Education: Data and Governance in Europe (pp. 47-65). London \& New York, NY: Routledge.

Gurova, G., \& Piattoeva, N. (2018). A post-Soviet audit culture: Changing practices and subjectivities of schoolteachers in a Russian region. In L. M. Carvalho, L. Levasseur, L. Min, R. Normand, D. Oliveira, \& D. Andrade (Eds.), Education Policies and the Restructuring of Educational Professions. Dordrecht: Springer.

Hansen, H. K., \& Flyverbom, M. (2014). The politics of transparency and the calibration of knowledge in the digital age. Organization, 22(6), 872-889.

Hansen, H. K., \& Mühlen-Schulte, A. (2012). The power of numbers in global governance. Journal of International Relations and Development, 15(4), 455-465.

Hartong, S. (2016). Between assessments, digital technologies, and big data: The growing influence of "hidden" data mediators in education. European Educational Research Journal, 15(5), 523-536.

INEP. (2015, August 12). Notícias: Inep promove encontro de trabalho para debater instrumentos de monitoramento do PNE. Retrieved from http://portal.inep.gov.br/artigo/_/asset_pub lisher/B4AQV9zFY7Bv/content/inep-promove-encontro-de-trabalho-para-debaterinstrumentos-de-monitoramento-do-pne/21206

INEP. (2016, September). Sistema De Avaliação Da Educação Básica, Edição 2015, Resultados. Retrieved from download.inep.gov.br/.../saeb_2015_resumo_dos_resultados.pptx

INEP. (n.d.a). Devolutivas Pedagógicas. Retrieved July 16, 2017, from http://portal.inep.gov. br/artigo/-/asset_publisher/B4AQV9zFY7Bv/content/inep-promove-encontro-de-tra balho-para-debater-instrumentos-de-monitoramento-do-pne/21206

INEP. (n.d.b.). Institutional. Retrieved March 24, 2017, from http://portal.inep.gov.br/web/ guest/conheca-o-inep

INEP. (n.d.c). Saeb. Retrieved March 24, 2017, from portal.inep.gov.br/web/guest/educa cao-basica/saeb

Kauko, J., Centeno, G. V., Candido, D. H. H., Shiroma, E., \& Klutas, A. (2016). The emergence of quality assessment in Brazilian basic education. European Educational Research Journal, 15(5), 558-579.

Landahl, C., \& Lundahl, J. (2013). (Mis)trust in numbers: Shape shifting and directions in the modern history of data in Swedish educational reform. In M. Lawn (Ed.), The Rise of Data in Education Systems: Collection, Visualisation and Use (pp. 57-78). Oxford: Symposium Books.

Lascoumes, P., \& Le Galès, P. (2007). Introduction: Understanding public policy through its instruments - from the nature of instruments to the sociology of public policy instrumentation. Governance, 20(1), 1-21. 
Lawn, M., \& Segerholm, C. (2011). Europe through experts and technologies. In J. Ozga, P. Dahler-Larsen, C. Segerholm, \& H. Simola (Eds.), Fabricating Quality in Education: Data and Governance in Europe (pp. 32-46). London \& New York, NY: Routledge.

Luk'yanova, E. (2012). Russian educational reform and the introduction of the unified state exam. A view from the provinces. Europe-Asia Studies, 64(10), 1893-1910.

Maroy, C. (2009). Convergences and hybridization of educational policies around "post bureaucratic" models of regulation. Compare, 39(1), 71-84.

Miller, P., \& Rose, N. (1990). Governing economic life. Economy and Society, 19(1), 1-31.

Minina, E., Piattoeva, N., Centeno, V. G., Zhou, X., \& Candido, D. H. H. (2018). Transnational policy borrowing and national interpretations of educational quality in Russia, China, and Brazil. In I. Silova \& M. Chankseliani (Eds.), Comparing Post-Socialist Transformations: Education in Eastern Europe and Former Soviet Union. Oxford: Symposium Books.

Piattoeva, N. (2015). Elastic numbers: National examinations data as a technology of government. Journal of Education Policy, 30(3), 316-334.

Piattoeva, N. (2016). The imperative to protect data and the rise of surveillance cameras in administering national testing in Russia. European Educational Research Journal, 15(1), 82-98.

Porter, T. (1994). Objectivity as standardization: The rhetoric of impersonality in measurement, statistics, and cost-benefit analysis. In A. Megill (Ed.), Rethinking Objectivity (pp. 197-238). Durham: Duke University Press.

Rasmussen, P., \& Zou, Y. (2014). The development of educational accountability in China and Denmark. Education Policy Analysis Archives, 22(121).

Rinne, R., \& Ozga, J. (2011). Europe and the global: The role of the OECD in education politics. In J. Ozga, P. Dahler-Larsen, C. Segerholm, \& H. Simola (Eds.), Fabricating Quality in Education: Data and Governance in Europe (pp. 66-75). London: Routledge.

Rose, N., \& Miller, P. (1992). Political power beyond the State: Problematics of government. British Journal of Sociology, 43(2), 173-205.

Rottenburg, R., \& Engle Merry, S. (2015). A world of indicators: The making of governmental knowledge through quantification. In R. Rottenburg, S. E. Merry, S.-J. Park, \& J. Mugler (Eds.), The World of Indicators: The Making of Governmental Knowledge Through Quantification (pp.1-33). Cambridge: Cambridge University Press.

Selwyn, N. (2016). "There's so much data": Exploring the realities of data-based school governance. European Educational Research Journal, 15(1), 54-68.

Souto-Otero, M., \& Beneito-Montagut, R. (2016). From governing through data to governmentality through data: Artefacts, strategies and the digital turn. European Educational Research Journal, 15(1), 14-33.

State Council of the People's Republic of China. (2010). 国家中长期教育改革和发展 规划纲要 2010-2020年 [Outline of China's national plan for medium and long-term education reform and development 2010-2020]. Retrieved from www.gov.cn/jrzg/201007/29/content_1667143.htm

Steiner-Khamsi, G. (2016). Global indicators and local problem recognition: An exploration into the statistical eradication of teacher shortage in the post-socialist region. In K. Mundy, A. Green, B. Lingard, \& A. Verger (Eds.), The Handbook of Global Education Policy (pp. 573-589). West Sussex: John Wiley \& Sons.

Tsing, A. (2005). Friction: An Ethnography of Global Connection. Princeton, NJ: Princeton University Press.

Tsoukas, H. (1997). The tyranny of light: The temptations and the paradoxes of the information society. Futures, 29(9), 827-843.

Tyumeneva, Y. (2013). Disseminating and Using Student Assessment Information in Russia. Washington, DC: World Bank. 


\section{Nelli Piattoeva et al.}

Xinhua. (2010, 29 November). 我国加强基础教育质量监测 监测学生全面素质 [China Strengthens Basic Education Quality Monitoring - Monitoring the Overall Quality of Students]. Retrieved from www.gov.cn/jrzg/2010-11/29/content_1755670.htm

Zhang, H., \& Wan, D. (2017). Status of Chinese science education reforms: Policies and development framework. In L. L. Liang, X. Liu, \& G. W. Fulmer (Eds.), Chinese Science Education in the 21st Century: Policy, Practice, and Research (pp. 5-30). Dordrecht: Springer.

Zhou, X., Suominen, O., Fan, Y., Kallo, J., \& Rinne, R. (forthcoming). Trajectory of Reforms to Education Supervision in Contemporary China. 


\title{
$7 \quad$ Effects of quality assurance and evaluation on schools' room for action
}

\author{
Galina Gurova, Helena Candido, and Xingguo Zhou
}

\section{Introduction}

This chapter's purpose is to explore the room for action which opens for schools with the emergence of quality assurance and evaluation policies. Other researchers have studied the relationship between schools and policy. For example, Tyack and Cuban (1995) have analysed policy reform and policy implementation in schools; Braun, Maguire \& Ball (2010), Braun et al. (2011), and Maguire, Braun \& Ball (2015) have examined policy enactment in schools; Ball and Maroy (2009) have focused on schools' responses to internal and external conditions; and Falabella (2014) has investigated the effects of accountability policies within schools. Previous research indicates that the relationship between schools and policy is affected by a multitude of objective and subjective variables. Furthermore, "policy ... cannot be reduced to an algorithm ... and the school cannot be reduced to policy" (Ball et al. 2011: p. 637). Finally, there are "discretionary spaces" in schools "in and beyond policies", that is, spaces policy does not reach because of actors' agency (teachers' good ideas or alternative solutions), chance, momentum, or the nature of the object or subject under the policy radar (Maguire, Braun \& Ball 2015: p. 497). The topic is thus far from exhausted.

This chapter contributes new perspectives to the study of school reforms. First, we approach the relationship between policy and schools through the lens of governance theories. As demonstrated in the subsequent section and in the book's other chapters, quality assurance and evaluation (QAE) acts as a means of governance, and in this chapter, we scrutinise the local mechanisms of this governance through evaluation. Second, our investigation of schools' room for action relies on the analytical framework of CADEP (see Chapters 1 and 2; also Kauko 2013; Kauko et al. 2012), which prompts us to view schools primarily as political actors. CADEP postulates that the key to understanding local policy change lies in the analysis of local dynamics: the changing interrelations, intertwinement with different levels, relations between actors and institutions, and the main discursive formations and practices. CADEP analyses three dimensions: the political situation, the political possibilities, and the political room for action. We are primarily concerned with the room for action or the 
potential of actors to exploit existing situations and possibilities, and we use the theoretical frames of organisational analysis and the concepts of economic and symbolic capital to explore schools' opportunities (or lack of opportunities) in respect of QAE.

We start with a description of national QAE policies related to school performance evaluation in Brazil, China, and Russia. These policies create the conditions in which local education authorities govern schools. We then describe local governance mechanisms, which we see as key constitutive elements for creating the room for action of schools as political actors. Finally, we analyse the opening or restricting of schools' opportunities in this room for action. The following questions guide our investigation: 1) How do local authorities utilise QAE in governing schools and why and towards what ends do they use QAE?

2) What are the opportunities which emerge for schools in relation to local authorities' utilisation of QAE?

The following sections present the theories which facilitated data analysis and interpretation of results; a description of the case localities in Brazil, China, and Russia; and a brief overview of national school performance evaluation policies and school-level findings.

\section{QAE in local governance}

QAE has become a strategic governance tool in education politics. Its dynamics are therefore manifested across the globe at different levels, from the transnational to the local (see Ozga et al. 2011). To analyse how QAE is used in local governance, we address three distinctive theories or models of governance which stress QAE in specific ways: 1) the "bureaucratic-professional" model of governance; 2) new public management; and 3) governance at a distance. We briefly describe each in the following paragraphs.

The "bureaucratic-professional" model of governance (Maroy 2008) refers to traditional governance models such as formal communication, labour division, hierarchical position, standardisation, and emphasis on qualification, specialisation, and professionalisation, which are commonly associated with the use of Weber's idea of efficient and rational processes to organise and maintain the social order (e.g., Weber 2015 [1921]). The general claim of traditional bureaucracy is that it is easier to govern rational organisational structures which share the same principles as diverse organisations (see also Weber 1949 [1904]). Conformity to general rules and the equality of treatment are emphasised.

To ensure quality of education in this governance model, the state issues norms, rules, and regulations, and controls the compliance of education organisations and actors to them through such instruments as inspections. Quality of education is understood traditionally in terms of teaching quality, which the state regulates in cooperation with organised education bodies (for example, teacher unions and associations) (Maroy 2008: pp. 15-16). To enhance quality, the state organises standardised teacher training and assumes responsibility for the provision of sufficient inputs in education institutions. 
New public management (NPM) is a term coined in the late 1980s to address the "new" approach to the management of public organisations which is inspired by economic rationalism and business practice (see Hood \& Jackson 1991). Its emergence and propagation were intended to improve public service efficiency by applying private sector management models to public organisations (see Osborne \& Gaebler 1993). NPM applies an entrepreneurial spirit to the public sector, reinforces decentralisation, encourages the use of quasimarket structures for governance, and emphasises control of outputs. Citizens are regarded as consumers and public servants as managers, providers, or suppliers when corporate governance premises are adopted. These "new" relationships in the political arena and public sphere are regulated by accountability regimes and performance management. The latter comprises performance standards and evaluation.

In education, responsibility for outcomes shifts to education "service providers" (schools and teachers), who are guided by national standards. Comparative data and instruments such as "best practices" and rankings orient policymaking. The state incentivises education providers to improve quality with quasi-market mechanisms: the introduction of per capita educational funding, which fosters competition between schools, and the implementation of performance-based salaries and benefits, which increases competition among school personnel. "Consumers" are students and their families, as well as the entire society supporting public education as a common good through taxes. The NPM model of education governance endorses accountability and transparency to make "consumers" aware of the quality of the service delivered by the "providers". This is accomplished through QAE mechanisms such as external evaluations with publicised results assumed to empower consumer choice. The connection of evaluation to performance-based funding and salaries accentuates rational NPM ideas and produces a constant feedback cycle in which outputs feed inputs and vice versa (for a detailed examination of NPM in general education see e.g., Gunter et al. 2016).

The third governance model which we employ in our analysis of local governments' QAE use also emerged in the 1980s. Governance at a distance, as Chapter 6 described in more detail, departs from traditional governance methods (legislation, prohibitions, and regulations) and embraces increased autonomy and self-responsibility (Kickert 1995). This is enabled by reliance on the power of expertise (see Latour 1987) and implies that actors share a significant degree of autonomy based on their will to engage in process and conduct (Miller \& Rose 1990: p. 14). In this paradigm, processes are not always prompted by the centre or government, but by an interrelated network of more or less autonomous actors. The most obvious advantage of such a governance model is that focus on individual agency diminishes the likelihood of resistance to governance measures (Kickert 1995).

QAE procedures contribute to education governance at a distance in several ways. Evaluation schemes produce numerical information, used for comparison and benchmarking, which becomes the key steering tool (Nóvoa \& 
Yariv-Mashal 2003). QAE policies set and enforce standards against which education (education institutions' service, education staff, and education outcomes) is measured, legitimising reward and punishment by government authorities. Additionally, QAE increasingly introduces self-evaluation practices. While these appear permissive and self-initiated, they need to comply with standardised indicators and central regulations. All these policies and practices implicitly emphasise constant self-regulation and self-improvement (Lawn \& Grek 2012: p. 146). Ball (1993: p. 111) suggests "constraints are replaced by incentives", "prescription is replaced by ex-post accountability based upon quality or outcome assessments", and "coercion is replaced by self-steering [under] the appearance of autonomy". Another way QAE enhances governance at a distance is provided by education outcomes in a variety of rankings, ratings, indicators, and reports. These are publicised and often prepared by the media with the purpose of modulating the decisions and actions of students and their parents (e.g., Lingard et al. 2016).

\section{Schools as political actors}

We see schools as political actors because they possess at least some degree of political power, which enables them to influence education decisions, policies, and outcomes. Thus, our analysis of schools' room for action is informed by the political frame of organisational analysis (Bolman \& Deal 2013). This lens facilitates the interpretation of local data, since it enhances understanding of the ways in which schools utilise QAE policies to gain power and resources. Within the political frame, education can be viewed as an ecosystem in which schools adjust to external pressures and interact with other ecosystem constituents (local education authority bodies, families, and commercial providers of education services) to obtain resources. Bolman and Deal (2013) refer to the different resources required by any organisation, such as time, money, and attention (p. 26) and describe the internal resources connected to an organisation's personnel: people's skills, attitudes, energy, and commitment (p. 117).

Bolman and Deal (2013) outline multiple sources from which organisational actors can obtain power and influence, which are also necessary in the struggle for resources. Identifying such sources is useful to an analysis of the political interaction between education authorities and schools. For example, local government authorities can be viewed as possessing a coercive power based on the ability to legitimately constrain, prohibit, interfere, or punish. Local authorities' power may also be based on the control of rewards - the ability to deliver jobs, money, and political support. Concomitantly, schools may draw influence from other sources, in particular, from their expertise and reputation, alliances and networks, and control of agendas (for a more detailed description of sources of power see Bolman \& Deal 2013: pp. 225-242).

To broaden the perspective of the resources schools can gain through QAE policies, we use the concept of material and symbolic benefits, which stems from the distinction between economic and symbolic capital (see Bourdieu 
1984 [1979]; Bourdieu 1998 [1994]). Bourdieu (2013 [1980]) argues that economic and symbolic capital are inextricably combined in the social space; one complements and reinforces the benefits of the other. The material benefits schools can obtain through QAE policies are easier to track and measure, because in most situations, they are connected to government budgets or domestic aid programmes. At the same time, not only do individual interests lie in the material order, but individuals and organisations aim to enhance symbolic dispositions, such as prestige, status, and honour, in acting in the social space (Pinto 2000). The value of symbolic benefits arises from the recognition (perception, understanding, and assurance) of relationships established between those who possess and utilise symbolic capital (Pinto 2000). Symbolic benefits can be obtained from a wide constellation of sources. For example, the achievement of a top-ranking position in league tables or awareness (through advertising or other marketing campaigns) of good scores in standardised evaluations can afford valuable symbolic benefits to schools.

\section{Case localities}

Our data were collected in selected localities in each of the case countries through document analysis, interviews, and observations (details on data collection and analysis are provided in Chapter 2). Given the data collection methodology, our findings are not representative of the countries or localities in which our research was undertaken. We aim to reveal the diverse mechanisms of QAE policies' influence and to understand the logic and interests of schools concerning performance evaluation mechanisms. However, when analysed comparatively, the perspectives of local education practitioners reveal similar patterns which are arguably meaningful for a more general analysis of schools' room for action.

In Brazil, the data were collected in the southern state of Santa Catarina (population 6.4 million). The state's social indicators are among the highest in the country and across Latin America. Its prosperity derives from its diversified and industrialised economy. We selected Santa Catarina for our research because it has been especially active in the introduction of QAE policies. It is the only Brazilian state to order a report from the Organisation for Economic Cooperation and Development (OECD), and the 2010 Programme for International Student Assessment (PISA) recognised Santa Catarina as the leader in Brazilian QAE. Since 2005, Santa Catarina has attained the highest IDEB (Index of Basic Education Development) of all Brazilian states. Interviews and observations were conducted in three large public schools (each with around a thousand students and fifty teachers) and in key state and municipal education organisations.

In Russia, we conducted our local study in the Republic of Chuvashia (population 1.3 million), which is approximately 650 kilometres from Moscow. Chuvashia is representative of mid-size, middle-income regions, with about half its population of non-Russian ethnicities. The region has a 
well-developed QAE system which has received positive reviews from external evaluators and is often presented as an example of best practice at training sessions for QAE professionals (Bochenkov 2013). The World Bank guided the education reforms implemented in the republic. Our local case from Chuvashia is Cheboksary, a city of half a million and the capital of the republic, as well as the centre from which all regional QAE initiatives originate. We collected this chapter's interview and observation data primarily from two public schools in the same city district, as well as from municipal education organisations.

Local data collection in China followed a different pattern because of schools' restricted accessibility. Intensive school observations were not allowed, so our analysis relies solely on data from interviews with school principals and deputy principals conducted in seven schools from two provinces in Northern China. One province belongs to a well-developed region. New education reforms are being piloted and tested in the locality, making it one of the most advanced areas in adopting national QAE policies. The other, situated on the coast, can be described as moderately developed, with an income level slightly above the Chinese average. Although it has a reputation for producing competitive students, it is neither labelled nor known in China as the most active or pioneering in innovating and implementing education reform. While the process of QAE policy introduction varies across different provinces, here the policy has been adopted moderately quickly. The schools visited in the two provinces varied greatly in their history, ranking positions, and student bodies. We conducted interviews at different types of schools with the goal of obtaining greater diversity in interviewees' positions and opinions.

\section{The rise of school performance evaluation in Brazil, China, and Russia}

In each country, new evaluation instruments measuring students', schools', and teachers' performance have recently been added to the traditional QAE system (Chapter 3 discussed the development of national QAE systems in detail). In Brazil, such performance evaluation instruments are the SAEB (Basic Education Evaluation System) and the IDEB (Index of Basic Education Development); in Russia, they are the national examinations (GIA), which assess students' education outcomes after grades 9 and 11; in China, they are the NAEQ (National Assessment of Education Quality), which assesses students' academic achievement in grades 4 and 8 .

Education statistics - or the "school census" - in Brazilian education began in 1931. The collection of statistics was gradually decentralised to the Brazilian states, which then sent a compiled data set to the federal government. The SAEB was introduced in 1990. It consists of two principal biannual assessments of maths (problem solving) and Portuguese (reading), one involving a sample of pupils in both primary and secondary schools, the other applying to all pupils in public schools registered in grades 5 and 9 and popularly known as Prova 
Brasil. SAEB results are used in calculating the IDEB, alongside school flow data (progression, retention, and dropout rates) provided by the school census. This indicator was created in 2007 to measure the quality of each school, municipality, and state and the overall quality of national education.

The SAEB is claimed to contribute to the improvement of education quality and the universalisation of school access by subsidising policy formulation, reformulation, and monitoring (INEP 2016). It is intended to enable a better understanding of the variables which influence pupils' performance. The SAEB is also intended to increase participation of parents and society in education (Brasil 1988, 1996, 2007, 2014). Finally, researchers envision the SAEB as an instrument to enhance local education management at sub-national levels (Machado \& Alavarse 2014).

The SAEB and IDEB are national policies. However, Brazilian states and municipalities, which are the country's major providers of public education, have the autonomy to develop their own student performance evaluations, and use them differently for simple comparison, diagnosis, school and staff accreditation, and performance-based remuneration. Around twenty states (Brooke, Cunha, \& Faleiros 2011) and more than 1,500 municipalities (Bauer, Pimenta, Horta Neto, \& Sousa 2015) coordinate a standardised evaluation in addition to the SAEB. All evaluation mechanisms in primary and secondary education, except for university entrance examinations (vestibular and ENEM), are low-stakes.

In 2007, however, the school census started to investigate student and teacher data, comprising data about school infrastructure, docents, enrolment, school hours, and school flow by level, stage, and type of education. The school census is a reference for calculating public school funding as well as for managing several federal programmes. Besides being responsible for the collection of these reports, the principals of several Brazilian public schools are also accountable for the fulfilment of action plans derived from management projects they presented when they were elected.

In China, education supervision comprising administrative and education inspections plays a major role in school quality assurance as a sub-system which complements local education governance. The supervision service collects statistical information on schools and ensures that education policies and plans are implemented by schools as expected. Local governments provide schools with funding, salaries, in-service training, and promotion for school staff based on this information.

In 2007, China introduced a new national assessment of education quality (NAEQ), employing standardised testing as a supplement to education supervision, which resembles international large-scale assessments, such as PISA, and Trends in International Mathematics and Science Study (TIMSS) (NAEQ 2015). The NAEQ evaluates students' achievement in Chinese, mathematics, and science. It also includes indicators of students' physical and mental health and socio-economic conditions. Assessment results are accumulated in a national database to inform policymaking. Performance data are also circulated 
among local education actors. The report is delivered by the NAEQ's national centre to avoid different provinces or localities competing with each other, and it aims to provide comprehensive information to policymakers so they can learn the real level of educational development and problems in schools. The performance report is sample-based, and since 2015, all Chinese provinces and municipalities have received an annual assessment.

As China has a long history of ranking the quality of education with examination scores or other administrative methods, this new model of testing, along with the popularisation of student-centred pedagogy, is expected to use quality evaluation to reduce ranking and ruthless competition in schools. China's ten-year blueprint for education development between 2010 and 2020 (State Council 2010) outlines the central government's intention to renew and upgrade evaluation practice at all levels. Nevertheless, at the local level, school quality is largely defined by students' examination scores, which determine their opportunities to enter the next education levels. The scores thus remain parents' primary concern.

In Russia, the traditional instruments of quality control in school education are inspections and school reports. Until 2009, school-leaving examinations were conducted by each school, supervised by the local education authorities. Examination, end-of-quarter, and end-of-year grades served as the main indicator of students' educational achievement. Policymaking was also informed by statistical information on school facilities, teacher qualifications, and student numbers. These data and grades assigned by schools are still included as indicators in the quality evaluation system. However, they are complemented by data from diverse large-scale assessments of student achievement and largely from national examinations.

National examinations were introduced in the 2000s as a key element of the newly developed system of evaluation and quality control in education. Their introduction was a way to ensure the "unity of educational space" across the diverse country, and at the same time, these standardised tests were to produce statistics on education quality for more informed policymaking. Finally, at the time of its introduction, the national test was acknowledged as a strong measure of equality and quality improvement (Bolotov 2004).

The Unified State Exam (USE, or GIA-11) is sat on completion of the eleven-grade school education, and the State Final Attestation (SFA, or GIA-9) is undertaken in grade 9, the last grade of general education. Examinations test graduates' knowledge in two compulsory subjects (Russian and mathematics) and several chosen subjects. Passing the tests is necessary to obtain a graduation certificate and apply for the next level of education. Contents of the tests are developed independently of schools in connection with the compulsory state curriculum. Scores in both tests serve as the main indicators of education quality in national and regional policy documents on quality assurance, school rankings, teacher performance evaluation metrics, and even (until 2015) assessments of regional administrations' effectiveness (Piattoeva 2015). Thus, national 
examinations carry high stakes for all involved in education: students and parents, school workers, and the education authorities.

\section{Local governance of schools through quality evaluation and assurance}

The room for action of schools as political actors is conditioned by local education authorities' use of evaluation procedures. In each of our case localities, diverse control and governance measures are applied to schools based on performance. In considering the whole range of traditional and new QAE procedures implemented in each locality, we focus on developments in local governance models inspired by the introduction of performance evaluation instruments. Our data analysis was informed by the three theoretical models of governance described at the beginning of this chapter; our interviewees' specific accounts or other indicators in our research data caught our attention, because they were characteristic of a particular governance model. At the same time, we sought to reflect the complexity of local governance realities in our findings, not limiting them to models but enriching the understanding provided by a combination of the three theoretical devices.

The governance practices this section describes are those mentioned by our respondents, presented in the local policy documents we analysed, or which we observed in the localities. Hence, "Brazil", "Russia", and "China" in this section simply label the source of data and should not be taken to imply that the attributed governance practices are consistent across the countries.

\section{Evaluation as an indirect intervention}

In accordance with national discourses on evaluation and quality improvement, by introducing new evaluation procedures, local authorities seek to change school management and teaching methods without direct interference. Evaluation is regarded as a means of reorienting school staff to different aims more aligned with national education priorities and encouraging school management and teachers to devote extra effort to improvement. In all observed localities, schools were required to regularly produce specific documents in which they declared their goals and evaluated their progress (in Brazil this was labelled "action plans"; in China, "self-regulation"; and in Russia, "self-evaluation reports" and "plans for the improvement of the effectiveness of learning"). In other words, local authorities use QAE procedures to ensure and stimulate schools' self-improvement, based on the assumption that schools would probably not do this on their own.

Both the internal evaluation process, which requires an action plan, and the external evaluation process should demand action plans in order to overcome the appointed limitations and difficulties ... We want to make schools commit to start discussing evaluation, discussing self-evaluation, 
its own resources, what is more important, what is better, ideal, because if nobody discusses anything, nothing will be taken into account, and hardly anybody will do it. School management, for instance, has a huge commitment and in the end, induces this. In case it doesn't, everything gets very loose ... And that's how the human being is ... The teacher lets the routine get loose, students also get loose ... [when the teacher] does not demand, does not require people to take some position ... - then we know [what happens - a pessimistic scenario results].

(BR-S-11)

Attention is paid to school staff's ability to work with data. By training teachers to produce and analyse evaluation data, authorities expect them to become better informed of their students' learning gaps and to close them more successfully:

A teacher should be able to work with feedback, which means to do tests, to encourage advanced learning ... The problem is how to know, or, rather, how to influence what happens in the classroom, because the teacher needs to know what he or she is teaching.

(RU-M-2)

Stimulation of the production and management of data in schools is intended to improve staff's reflexivity and critical thinking and direct their attention to problems the authorities deem important. For example, a Russian interviewee said that one of the aims of evaluation was to make schools pay more attention to low-performing students (RU-M-2). In China, it is hoped that new evaluation will loosen the current overarching emphasis on examination results and redirect attention to students' well-being in schools and in their general learning context (State Council 2010). Evaluation is perceived not simply as a new tool but as a new way of thinking, an "evaluation culture" (BR-S-11), which should permeate schools' main practices, from planning and managing to classroom practice.

We have documents and bulletins that are specific to the principal, which give him a different view in relation to these indicators. We have bulletins for teachers, and there is one that students take home to their parents ... We invite 150 professionals to participate in workshops because we want them to be able to get all the knowledge, not only know how to read a Prova Brasil result, but to make them qualified to do a specific analysis of the results, and willing to know the indicators ... Our main objective is to strengthen this view, to enlarge this view and to make them gain more benefit from what is available today.

(BR-M-2)

We have never thought that context indicators can be used, for example, to introduce some new things, to form new administrative structure in 
schools, for example. [In schools] they are already interested to ensure that information is collected, so a [special] deputy principal is appointed who supervises evaluations ... Also new deputy principals for primary education are appearing. Previously, not all schools had them, but now there are all-Russia tests [vserossiiskie proverochnie raboty, national tests at the primary level], so there is a new [administrative position].

(RU-M-2)

Some of our interviewees from schools in Brazil and Russia expressed scepticism of the authorities' declared intention to foster improvement in schools. They regarded the "improvement through evaluation" discourse as a disguise for the authorities' real intention, which was to shift all responsibility for quality to schools and teachers. Numbers inadequately represented quality of education, school actors explained, and if the authorities were sincerely concerned about quality and the situation in schools, they would "come and see" instead of calculating indexes. This view was shared by an interviewee from the Russian local authorities:

When schools submit reports, [numerical] analysis, we still look at ... what problems reveal themselves [in these reports]. We understand that we need to go and visit these educational institutions, we should see and help them in this respect ... After national examinations we worked through all [identified problematic] issues with every [school] administration, we created a whole schedule of meetings with administrations, yes, we worked overtime for a week with our schools, discussed where the gaps are in those institutions, what to do to eliminate the gaps.

(RU-M-1)

This illustrates that authorities question the adequacy of data and numerical evaluation tools for quality assurance. The next section explains in more detail how evaluation is connected to other governance instruments.

\section{Justification of reward and punishment}

School inspections based on performance evaluation were common in our observed localities in China and Russia and are under discussion in Brazil. The functions of such inspections include identifying problems contributing to unsatisfactory school performance, demanding schools develop plans for improvement, and in some cases, applying sanctions. In Russia, inspections are authorised to issue fines and even suspend school licences. In China, schools' failure to meet performance standards may also have severe consequences. A first failure means the school will be disqualified from annual rewards, and a principal's promotion may be deferred. Teachers may lose the opportunity to pass their annual appraisal and gain promotion. If a school continues to fail within a given time, it may be suspended or closed. However, such extreme 
decisions are very rare and usually apply to "low-quality" schools. In public schools in both China and Russia, the principal's suspension is another potential consequence if the school consistently underperforms. Although such harsh measures prescribed by inspectors are relatively rare, the possibility of such measures places great pressure on schools to avoid poor results in performance evaluation. Inspection itself can function as a form of punishment or threat, even when high stakes for school administration are not attached to it, which we witnessed in Brazil.

Respondent: If there are some problematic issues, they need to be identified, to be demonstrated.

Interviewer: And what support was offered to schools that had many problems? Respondent: Well, there were not many of them, in practice ... In some, the directorate was changed (RU-M-2).

Nobody wants to receive the external commission, which is a commission created by the [sub-national authority] that goes to the school to check what led to a low IDEB in that school ... This process will induce everyone to grow, everyone to increase [IDEB], always, because nobody wants to have the thirty lowest [IDEB scores and be inspected].

(BR-S-11)

Performance evaluation also facilitates governance through diverse mechanisms which link evaluation results to provision of resources. First, evaluation can justify distribution of funds, including performance-based funding and salaries, project funding, and grants. Salaries of Russian school administrators and teachers contain a performance-based element. In the Russian case, locality students' GIA results are also considered in school and teacher contests and as criteria for participation in special projects involving extra funding.

We had an indicator connected to student absence in schools. Currently we still have it, but then we made a specific emphasis on it, we made [schools] watch these numbers more attentively. It was our goal to stimulate them with this criterion so that they would improve the situation. For example, if her or his salary depends on the improvement of this indicator, then ... there is a motivation for the manager to work on it.

(RU-M-2)

A Russian school principal reports,

The municipal Department of Education demands a certain percentage [of high grades which the school students need to obtain]. If we do not provide the required quality, it means that we produce pedagogical defects. Our funding is decreased then.... We could not even apply for some 
grants, because only schools without students with a criminal record could apply, and we have such students.

(RU-S-2)

In Brazil, high performance is not the only route to resources, as there are also national and sub-national government programmes for providing lowperforming schools with financial and technical support. Bonus funding to high-performing schools in some Brazilian regions is provided to reward staff performance, and some schemes function under which high-performing schools become sponsors and advisors of low-performing schools to improve the local education system's overall performance. In China, different localities have different traditions of encouraging schools to achieve better results in college entrance examinations. An interviewee reported of certain localities, "They give a bonus to some schools depending on how many students are recruited by Qinghua University or Peking University, or how many students are recruited by top universities" (CN-P-01).

In Russia and China, performance evaluation results count in awarding qualifications and honoured status to administrators and teachers. In Russia, professional qualification and status influence salary levels and are also crucial for professional recognition. In China, they are not connected to remuneration, but as symbolic rewards, they are highly valued, as a Chinese school inspector explained,

The punishment of a teacher who, for example, failed the moral evaluation, is that he or she cannot participate in teacher promotion in this year; he or she would not participate in the selection of honoured teachers. This is quite a severe punishment for a teacher. Think about that, if as a teacher you could not get promoted or become an honoured teacher because of a moral problem, how can you gain trust from students and parents?

(CN-S-05)

In all three case countries, low-performing schools are offered support in the form of supervision and training for teachers or peer assistance in teaching. However, some interviewees from schools regarded this practice not as support for teaching methods but as symbolic punishment, which labelled such schools and teachers as incompetent.

They [the local authorities] came up with a very "interesting" project. For example, one subject teacher in our school got six fails in GIA results [six students from his/her class failed in the subject examination]. And this class is to be visited by another teacher who had no fails, so that he/she can conduct the preparation-for-GIA lessons with the students of this class. What is the implementation of this project going to demonstrate? That this teacher [the one who had fails] did not do his/her work, and another lady now comes - oh so smart, look, children! So, what image of this class's 
teacher is this project going to create? Do they think of it at all? And this [intervention by a different teacher] is not going to work, in just one week, because students do most for the teachers they know and love.

(RU-SM-4)

The practice of using performance evaluation as justification for reward and punishment does not always mean that authorities implement evidence-based policy. Sometimes decisions about reward or punishment come before evaluation results, which are subsequently used as justification for decisions. This mainly concerns evaluations in the form of inspections but is sometimes applied to numerical performance evaluations. A Russian interviewee told us that a ranking based on numerical indicators was considered inaccurate by a supervising authority because it contradicted the authority's opinion of who should occupy the top of the ranking:

Last year we tried to rank administrators based on the indicators given by the [regional] Ministry [of Education] ... This was ... even a small argument, you couldn't call this a conflict, but just an argument about "why you have chosen the wrong school [as ranking leaders].

(RU-M-2)

In Brazil, some school interviewees perceived that evaluation criteria had been developed to accommodate political interests and produce better results.

I see that the main role of external evaluation is to manipulate indexes, manipulate a situation so public schools look as if they ... have good conditions. I see that there is a clear lowering of education [standards] in public schools, and this [is] veiled [by politicians, otherwise they will not be elected] ... That's when the index is essential.

(BR-MS-1)

\section{Accountability of authorities}

Local authorities themselves are subject to evaluation and sanctions because they occupy an intermediary position between schools and the sub-national and national levels. Local officials need to demonstrate that they are successfully implementing national and sub-national regulations and doing something about schools' identified problems. In other words, local authorities undertake evaluations to report to their own supervisors.

Since 2009 we have established a notification system of supervision results. The results [are] included as one of the main indicators of the county government performance to offer evidence for reward or punishment ... Moreover, the problems that have been found in a previous inspection will be put into the special checking list [for] next year.

(CN-M-02) 
It is therefore in local officials' best interest to ensure that schools pass inspections. A Russian interviewee reported,

Supervision authorities visit [schools] quite often, be it [the] prosecutor's office or the Department for Supervision and Control in Education. They take a certain aspect and review it. But before they visit I have already assigned a specialist for this task; she goes in advance and, together with the school, checks all the documents. [She] also observes lessons, because sometimes there are [federal] tests in different subjects. She, so to say, prepares schools for these inspections. And when the Department for Supervision and Control comes, she is there with them and polishes (otrabatyvaet) certain issues.

(RU-M-1)

A Chinese respondent explained that the need for local inspections arose from other evaluations:

Lots of evaluation of schools is still based on school [graduates'] performance in college entrance examination results. Schools might go to another extreme to [devote] all the time to the examined subjects. Many schools don't even teach the subjects not tested. So, supervision makes sure that no such actions happen in schools.

(CN-S-01)

With the lack of supervision and inspection in Brazil, sub-national governments tend to use teacher training to ensure the curriculum has been followed and the evaluation culture has spread.

Local authorities are also accountable to the public, especially parents, so authorities use QAE instruments to demonstrate their work and schools' quality to the local community. At the same time, evaluation serves as a means by which authorities involve community actors in the governance or support of schools. For example, both Brazilian legislation and public opinion call for the participation of community and families in education and, in a context of high social inequality, voluntary work and donations often target low-performing schools. The authorities thus view evaluation as a tool to provide relevant information on schools to the community; evaluation needs "to reflect the reality of education ... [and] raise [the] involvement [of community members in] schools" (BR-S-9). In Russia, some local quality assurance measures, including inspections, are implemented in response to parents' complaints. Self-evaluation reports prepared by Russian schools are also published to provide parents and the public with information about school quality. Chinese interviewees also mentioned that evaluation and inspection in some localities involve parents, the district community, and the media: "We [inspectors] interview students and parents, and then the community around the school. We also view the school archives, and then assess the implementation of rectification, [and] do [a] follow-up investigation" (CN-M-01). 


\section{Schools' room for action in QAE}

Local authorities' use of QAE in Brazil, China, and Russia to govern schools sets schools' room for action in their localities. Remembering the aims and actions of authorities described in the previous section, we now proceed to an analysis of school administrators' and teachers' reactions. In this section, we seek to answer our second research question: what are the opportunities which emerge for schools in relation to local authorities' utilisation of QAE? We look at schools' opportunities as political actors - their opportunities to obtain power and resources. For this analysis, we employ the typology of the sources of power (Bolman \& Deal 2013), which emphasises the diversity of such sources (or kinds of power). We consider not only material but also the symbolic resources schools can obtain, and focus on both those who gain and those who lose power and resources because of changing QAE policies.

\section{Evaluation as an internal management tool}

Some school administrators in Brazil and Russia eagerly embrace evaluation as an effective management instrument. They see comparison as a "natural way of human thinking" (RU-S-3 and BR-SS1) and use both traditional and new evaluation tools to encourage their teachers, students, and parents to work harder to get better results. Schools can refer to evaluation data at staff meetings to set goals for the upcoming period, identify student groups requiring extra attention, and praise high-performing teachers and scold low-performers. One of the Russian schools we observed organised an internal ranking of teachers based on their students' performance and regularly designed contests for students and staff members.

The internal quality control [vnutrishkol'nyi kontrol', a traditional procedure involving regular lesson observations and peer discussions] is the main thing! I always tell deputy principals: you can postpone anything, but do the internal control! One should reveal a problem in time and solve it quickly, then you will have good quality in the end. For example, in one grade 8 group students suddenly started getting fail marks. It turned out that their former teacher worked insufficiently, and the deputy principal didn't find it out in time. So, I went teaching ... that group, we cleaned a little bit ["cleaning" means getting rid of low-performing students, primarily by persuading them to transfer to another school], and in grade 9 they passed national examinations more or less satisfactorily, though there were still five fails in that ... group.

(RU-S-1)

When I see the IDEB, the first thing I do is to compare my school with others - I use all data... . I compare with other schools ... [in the neighbourhood] in order to understand, because the region has similar socioeconomic characteristics, so we can compare. This is natural and for me, 
indexes, numbers, they have a meaning ... I always use the indexes in the beginning of [the] school year in our pedagogical meetings. One of the first things I do is to show the indexes. Both the IDEB and other general indexes and government measures, as well as our internal indexes, retention, and dropout indexes, and what we will do in order to keep students at our school.

(BR-SS-1)

In China, our respondents mentioned various school initiatives such as the creation of extracurricular classes which were launched to gain additional scores in external evaluations. We witnessed no example of the appropriation of new QAE tools for internal school purposes.

\section{Schools' room for action in relation to resources}

The connection between evaluation results and resource distribution allows some schools and school workers to benefit from the new QAE system. Some interviewees said that students' high performance could secure the performance-based element of a salary (in Russia and in some Brazilian localities) and the obtaining of higher qualifications (in Russia and China). Low performance was perceived by our Russian and Chinese respondents as a potential threat to securing necessary funding, which we did not observe in Brazil, where low performers tended to receive assistance rather than punishment. Although Brazilian schools can obtain resources if they perform poorly in evaluation schemes, maintaining low scores in national and sub-national standardised tests is far from becoming a strategy for such schools to supply their needs. In Russia, where examination results carry high stakes for students, schools can also attract additional financial resources by offering exam preparation classes for a fee.

The principal very actively encourages additional paid-for classes. In grades 9 and 11 they are not really voluntary, and in other grades they are also strongly recommended to students, because it is very important for the school budget.

(RU-S-26)

Schools' high performance also indirectly creates opportunities to obtain better resources. First, it helps to attract better teachers, because salaries, career development, and reputation depend on performance evaluation results. It also helps to attract performance-oriented students. In Russia, schools receive per capita funding, so having more students is financially beneficial. This also applies to non-public schools in China ("non-public" includes expensive private schools and cheaper non-government schools, such as Minban schools):

School reputation is very important to us. Even if there were no inspection from the government, we would still do our best to improve quality 
because unlike public schools, our lives ... [depend] on students and how many students come here.

(CN-MBS-01)

\section{Reputation and influence}

School performance is converted into school reputation through unofficial media rankings (in all three countries), public self-evaluation reports (in Russia and China), and participation in contests and projects conditioned by performance (in all localities). A good reputation is itself valuable, as was frequently emphasised by our Chinese interviewees. It also motivates school personnel and students. A Russian teacher explained why high performance in examinations was important: "It is our school's prestige, and parents expect it from us, and my reputation in the city - I want to support it, not to lose it" (RU-S-27). Creating a good reputation and visibility is a long-term strategy to attract resources and influence:

You [as a school] should participate in contests, be visible, so that they [the authorities] see you, remember you afterwards. There are contests such as "Teacher of the Year" - we cannot hope to win ... those. But there are so many different contests, you can find one that does not depend on results [of students so much], in which you can win, if you read the criteria attentively ... Piloting [of federal or regional educational initiatives] - they [the authorities] don't give it to any [random] school. And if a school participates in piloting, if it organises city and regional seminars - the teachers [of this school] can then mention it in their qualification documents or in grant applications.

(RU-S-4)

Through participation in projects, contests, and so on, school administrations develop networks and coalitions which eventually help the school to informally influence education decisions and resource distribution. Another informal channel for schools' local and even regional influence is through influential parents of students, teachers (especially honoured teachers), or any prominent figure's participation in school activities (for example, war veterans participating in patriotic upbringing, sports champions invited to school competitions, or local business leaders invited to graduation events). Demonstrating high performance and creating local and regional visibility allows schools to attract powerful people to their informal networks.

The head of [the] city administration called me and reprimanded me: "Why do you solve your problems through veterans?" - but I didn't! We just invited this veteran, and he was in three wars, he is 96 years old, he met with Putin, we regularly invited him to school events, so he also wants to do something for us. He asks what we need, and we haven't yet got [good sports facilities]. 
Our observations in all three localities provided examples of schools with strong performance-based reputations which acted as "consultants" or "best practice providers" in their locality. In some cases, local education authorities delegated power to top-performing schools by making them official providers of expertise and advice (noted in all three countries).

The school that receives the bonus [for their high performance, in a scheme that is still under discussion] must, as ... compensation, offer some support, as ... [a] "sister school" to each school that hasn't been able to achieve the goal, in order to allow them to grow together.

To be frank, our [school's] quality and standards ... have exceeded those required by the inspection and evaluation. I think the function [of inspectors] to "guide and supervise" is [less applicable] to us, unlike weak schools that are supervised and guided by education inspection. Schools like ours are more of an example and something to be exported.

(CN-S-01)

\section{Low-performing schools' room for action}

The interdependence of financial, human, and symbolic resources leads to a situation where school performance evaluation results sustain a virtuous cycle of resource accumulation for high-performing schools and a vicious cycle for low performers, who are increasingly disadvantaged because of their students' poor results. Teachers in these schools cannot improve their qualifications, as they have few if any high-performing students. Hence, it is harder for schools to attract new teachers, not only because career opportunities are bleak but because work itself can be more demanding and less emotionally rewarding. There are also fewer opportunities to win in contests; in some cases, schools cannot even apply if their previous performance is poor.

It can be so that a teacher does not participate in any contests, but can explain well, is a good teacher ... I wish they would abolish those [performance-based principles of calculating] salaries, they only provoke conflict. Or ... [define] criteria in a different way, or ... give it to the school, so that we could ourselves evaluate our teachers.

(RU-S-2)

Implementation of QAE procedures is regulated, so schools have no option but to comply with them.

As for the documents [regulations] coming from above, some of them are very concrete, they are very comprehensive, for example, there are over forty items in the students' quality education regulations for school 
operations pushed forward by the province level. We cannot violate [any] of them, otherwise there will be punishments [for] us.

(CN-S-06)

Once every three years we have inspections, you know, [to see] whether we work in accordance with the licence, with the accreditation.

If our institution somehow violates some norms, we may lose our accreditation, we may lose our licence. Hence all these monitoring studies [monitoringi], self-evaluation reports, all these different reports [exist] - all this is just so that the institution works as it should work by law.

(RU-S-2)

Complying with regulations and government priorities, as well as improving numerically measured performance, carries high stakes even for well-established schools. The Brazilian data provided an example of how a supervising authority restricted resource access to a medium-performing school because it was pursuing its own principles in managing education (retaining low-performing students and those who did not reach the minimum required school attendance).

I had to go to the Education Secretariat in the evening ... to take the documentation, a process of around two or three hundred pages, to prove we did it right . . . I was, in some way, harassed during the meeting to override teachers' decisions ... to change the results of the teachers' meeting that retained around thirty students ... under the allegation that this [retention of students] would lower the school index [IDEB] ... With an intimidating speech [they said] "If you have any projects going on at school and the IDEB is [ongoing], and you are retaining students and the IDEB decreases ... we will end ... all these projects, we will close your labs.

(BR-MS-1)

While this Brazilian school openly resisted new evaluation policy and confronted the authorities, in China and Russia, we witnessed no example of schools refusing to comply with QAE policies or openly questioning them. However, evaluations may be resisted in hidden ways; in both Brazil and Russia, our respondents mentioned that evaluation results could be fabricated and that it was to some extent possible to retain traditional practices while formally implementing new regulations.

I believe it is illusory to think that there is total control through the [external] evaluations. Lots of schools and teachers find ways to manipulate the dynamics, including making the evaluation look better than what ... the students answered .... in the evaluation. 


\section{Conclusion}

A comparative study of local practice in Brazil, China, and Russia reveals that local governance through QAE is more multifaceted in all three countries than is nationally envisioned. The enacted QAE policies and their effects on schools do not stay within the limits outlined by policymakers. QAE instruments, such as large-scale assessments, and the data they produce are reinterpreted locally in accordance with existing practices of quality control and school governance and are biased towards the political interests of local actors who seek resources and power. The opening or restriction of political opportunities for schools therefore also seem to differ from national policies' original intentions. We demonstrate that a combination of governance theories, rather than one theory, is needed to understand the diverse ways in which QAE policies can enhance and change local governance. We also argue that the study of schools' political room for action constitutes an important dimension in the investigation of local policy effects.

We identify several ways in which local education authorities can use QAE for governance. First, by evaluating schools and training them to work with data, local authorities seek to change internal school processes, make schools set specific goals, and focus on problems they have identified. They also anticipate that schools will adopt a new regime of constant self-improvement and an evaluation culture and that teachers and administrators will inform themselves in new ways (by collecting and processing quantitative data) about students' learning gaps. Such aspirations are representative of governance at a distance, which aims to change subjects' behaviour through constant surveillance and their "voluntarily" committing to act in accordance with government designs.

Local authorities also use evaluation in connection with traditional control measures (inspections, restrictions, fines, appointing and dismissing school administrations) to justify political decisions. QAE thus reinforces authorities' control over schools. Evaluation also provides the ground for resource distribution (financial, material, and human) and access to rewards: performance-based funding and salaries, higher qualifications, and prestigious status. The provision of incentives to comply with new regulations, while allowing subjects a degree of operational freedom, characterises a governance model based on new public management. We found that some schools' local governance QAE practices could be viewed as "micro-level NPM", while QAE mechanisms shifted responsibility for quality from local authorities to schools.

In these ways, QAE policies can enhance traditional governance instruments, create new connections between implementation of regulations and provision of resources, and facilitate greater access to schools' internal processes, formalising them and subjecting them to authorities' control. QAE tools can also help local authorities to demonstrate their own efficiency in supervising organisations, to be accountable to the public, and to change interactions between schools, authorities, and the community. 
Brazilian, Chinese, and Russian schools are implementing QAE policies to comply with national and sub-national legislation and as a response to the governance measures we have described. Compliance with QAE policies opens exclusive access to various resources and powers to high-performing schools. Apart from utilising the "official" schemes of resource accumulation (per capita funding, performance-based salaries, improving teacher qualifications), schools may find ways to use QAE instruments to attract additional resources from students and parents. Improved visibility through participation in contests and rankings allows schools to assume new roles as experts and providers of best practice and to attract affluent people to their networks and thus increase their local influence, which facilitates further accumulation of resources. Reputation occupies a central position in our analysis because it functions as both a symbolic resource and a source of power. We observe that reputation is key to virtuous (in the case of high-performing schools) or vicious (in the case of lowperforming schools) cycles in which schools find themselves ensnared when schemes involving performance-based funding and salaries are implemented. In some cases, the schools we analysed also embraced QAE policies as a helpful tool for quality improvement and internal management.

The room for action of the schools which opposed new QAE policies appeared limited in our research results. Some schools resisted QAE policies because they contradicted the school's educational goals (for example, the Brazilian school which insisted on retaining students) and faced the consequences, while others made no attempt at resistance even when they disagreed with policies, because they were governed by national regulations. The multiple governance tools of local authorities appeared effective in enforcing QAE policies in all the schools we observed. However, we also observed that schools could practise hidden resistance and to a certain extent avoid QAE tools' penetration of schools' internal processes.

In revealing the different mechanisms of QAE policies' local influence, our findings raise questions for further investigation. How typical of these and other localities are the effects we observed? What conditions authorities' and schools' selection of specific mechanisms? How are relations between local education actors influenced by broader contexts, for example, by local authorities' degree of autonomy from national and sub-national government and that of schools from different levels of government, or by national and local governance legacies? Who benefits from QAE policies in different situations? Answers to these questions and more would greatly enrich the understanding of local education governance through QAE.

\section{Bibliography}

Ball, S. J. (1993). Education policy, power relations and teachers' work. British Journal of Educational Studies, 41(2), 106-121.

Ball, S. J., Maguire, M., Braun, A., \& Hoskins, K. (2011). Policy actors: Doing policy work in schools. Discourse: Studies in the Cultural Politics of Education, 32(4), 625-639. 
Ball, S. J., \& Maroy, C. (2009). School's logics of action as mediation and compromise between internal dynamics and external constraints and pressures. Compare: A Journal of Comparative and International Education, 39(1), 99-112.

Bauer, A., Pimenta, C. O., Horta Neto, J. L., \& Sousa, S. Z. L. (2015). Avaliação em larga escala em municípios brasileiros: o que dizem os números? Estudios em Avaliação Educacional, 26(62), 326-352.

Bochenkov, S. (2013). Uchitel', shkola, sistema obrazovaniia v zerkale EGE [Teacher, school, system of education in the mirror of the USE]. Problemy sovremennogo obrazovaniia, 3, 27-47.

Bolman, L. G., \& Deal, T. E. (2013). Reframing Organizations: Artistry, Choice, and Leadership. Chichester: John Wiley \& Sons.

Bolotov, V. (2004). EGE: Promezhutochnie itogi [USE: Interim results]. Voprosy obrazovaniia, 2, 155-167.

Bourdieu, P. (1984 [1979]). Distinction: A Social Critique of the Judgement of Taste. Cambridge, MA: Harvard University Press.

Bourdieu, P. (1998 [1994]). Practical Reason: On the Theory of Action. Stanford: Stanford University Press.

Bourdieu, P. (2013 [1980]). O Senso Prático (3rd ed.). Petrópolis, RJ: Vozes.

Brasil. (1988). Constituição da República Federativa do Brasil [Constitution of the Federal Republic of Brazil]. Brasília, DF: Senado Federal.

Brasil. (1996). Lei $n^{\circ}$ 9.394, de 20 de dezembro de 1996. Lei das diretrizes e bases da educação nacional [Law on the guidelines of national education] (LDBEN). Diário Oficial da República Federativa do Brasil, Brasília, DF, n. 248, 27.833-827.841, 24 dez.

Brasil. (2007). Decreto n. 6.094, de 24 de abril de 2007. Dispõe sobre a implementação do Plano de Metas Compromisso Todos pela Educação. Retrieved April 12, 2016, from www.planalto.gov. br/ccivil_03/_ato2007-2010/2007/decreto/d6094.htm

Brasil. (2014). Lei n. 13.005, de 25 de junho de 2014. Aprova o Plano Nacional de Educação PNE e dá outras providências. Retrieved April 12, 2016, www.planalto.gov.br/ccivil_03/_ato 2011-2014/2014/lei/113005.htm

Braun, A., Ball, S. J., Maguire, M., \& Hoskins, K. (2011). Taking context seriously: Towards explaining policy enactments in the secondary school. Discourse: Studies in the Cultural Politics of Education, 32(4), 585-596.

Braun, A., Maguire, M., \& Ball, S. J. (2010). Policy enactments in the UK secondary school: Examining policy, practice and school positioning. Journal of Education Policy, 25(4), 547-560.

Brooke, N. P., Cunha, M. A., \& Faleiros, M. (2011). A avaliação externa como instrumento da gestão educacional nos estados: relatório final. Belo Horizonte: Game/UFMG; Fundação Victor Civita.

Falabella, A. (2014). The performing school: The effects of market \& accountability policies. Education Policy Analysis Archives, 22(70).

Gunter, H. M., Grimaldi, E., Hall, D., \& Serpieri, R. (Eds.). (2016). New Public Management and the Reform of Education: European Lessons for Policy and Practice. London: Routledge.

Hood, C., \& Jackson, M. (1991). Administrative Argument. Aldershot: Dartmouth.

INEP. (2016). SAEB. ANEB e ANRESC (Prova Brasil). Retrieved June 10, 2016, from http:// portal.inep.gov.br/web/saeb/aneb-e-anresc

Kauko, J. (2013). Dynamics in higher education politics: A theoretical model. Higher Education, 65(2), 193-206.

Kauko, J., Simola, H., Varjo, J., \& Kalalahti, M. (2012). What could a dynamics perspective contribute to comparative research? In J. Kivirauma, A. Jauhianen, P. Seppänen, \& T. Kaunisto (Eds.), Koulutuksen yhteiskunnallinen ymmärrys [Social Perspectives on Education] (pp. 219-233). Turku: Finnish Educational Research Association. 
Kickert,W. (1995). Steering at a distance: A new paradigm of public governance in Dutch higher education. Governance: An International Journal of Policy and Administration, 8(1), 135-157.

Latour, B. (1987). Science in Action. Cambridge, MA: Harvard University Press.

Lawn, M., \& Grek, S. (2012). Europeanizing Education: Governing a New Policy Space. Oxford: Symposium Books.

Lingard, B., Martino, W., Rezai-Rashti, G., \& Sellar, S. (2016). Globalizing Educational Accountabilities. New York, NY: Routledge.

Machado, C., \& Alavarse, O. M. (2014). School quality: Impacts and challenges of external evaluation. Educação \& Realidade, 39(2), 413-436.

Maguire, M., Braun, A., \& Ball, S. J. (2015). "Where you stand depends on where you sit": The social construction of policy enactments in the (English) secondary school. Discourse: Studies in the Cultural Politics of Education, 36(4), 485-499.

Maroy, C. (2008). The new regulation forms of educational systems in Europe: Towards a post-Bureaucratic regime. In N. C. Soguel \& P. Jaccard (Eds.), Governance and Performance of Education Systems (pp. 13-33). The Netherlands: Springer.

Miller, P., \& Rose, N. (1990). Governing economic life. Economy and Society, 19(1), 1-31.

NAEQ. (2015). 基础教育质量监测信息简报 [Brief Report on Works of National Assessment of Education Quality]. Retrieved August 20, 2016, from www.eachina.org.cn.

Nóvoa, A., \& Yariv-Mashal, T. (2003). Comparative research in education: A mode of governance or a historical journey? Comparative Education, 39(4), 423-438.

Osborne, D., \& Gaebler, T. (1993). Reinventing Government: How the Entrepreneurial Spirit Is Transforming the Public Sector. Reading, MA: Addison-Wesley.

Ozga, J., Dahler-Larsen, P., Segerholm, C., \& Simola, H. (Eds.). (2011). Fabricating Quality in Education: Data and Governance in Europe. London: Routledge.

Piattoeva, N. (2015). Elastic numbers: National examinations data as a technology of government. Journal of Education Policy, 30(3), 316-334.

Pinto, L. (2000). Pierre Bourdieu e a Teoria do Mundo Social. Rio de Janeiro: FGV.

State Council. (2010). Guidelines of National Medium- and Long-Term Educational Reforms 2010-2020. Beijing: Ministry of Education. [Original in Chinese].

Tyack, D., \& Cuban, L. (1995). Tinkering Toward Utopia: A Century of Public School Reform. Cambridge, MA \& London: Harvard University Press.

Weber, M. (1949 [1904]). Objectivity in social science and social policy. In E. A. Shils, A. Edward, \& H. A. Finch (Eds.), Max Weber on the Methodology of the Social Sciences. Glencoe, IL: Free Press.

Weber, M. (2015 [1921]). Bureaucracy. In T. Waters \& D. Waters (Eds.), Weber's Rationalism and Modern Society: New Translations on Politics, Bureaucracy, and Social Stratification (pp. 73-127). London: Palgrave Macmillan. 


\title{
8 Alternative views of the future of quality assurance and evaluation
}

\author{
Johanna Kallo, Tuomas Takala, \\ Vera Gorodski Centeno, and Olli Suominen
}

\section{Introduction}

In this chapter, we analyse the views of Brazilian, Chinese, and Russian actors concerning the future development of quality assurance and evaluation. Our interest is in examining actors' perceptions within a wider historical and political context, with the aim of comparing the possible futures of QAE in the three case countries. The chapter complements the findings presented in previous chapters by focusing not only on past experiences but also on the future aims which guide present policies and action (see Adam 2010; Andersson 2012; Andersson \& Rindzevičiūte 2016). By looking at the future goals set for education QAE, we aim to advance research into one of the book's key themes, namely, how QAE policies shape education practice and discourse.

We draw on critical futures studies (Bussey, Inayatullah, \& Milojevic 2008; Ogilvy 2004), which perceive the future as a site of alternatives, instead of attempting to predict it. Moreover, we subscribe to the argument that the task of the research on possible futures is not only to contour the unknown but to rethink the structures of power and governance embedded in official future scenarios and forecasts (Cruz 2015; Inayatullah 1990, 2002; Slaughter 2002). These ideas are related to the theoretical notions of complexity referred to in the book's earlier chapters, one of their key themes being the future's unpredictability (Biesta \& Osberg 2010; Cairney \& Geyer 2015). Predicting the future of complex systems is difficult, which is why researchers who recognise this challenge refrain from definite forecasts and focusing on alternative future images and scenarios. The idea of alternative futures is also reflected in this chapter's title, which refers to the differing perceptions arising from the research data.

Investigating the future as a site of alternatives helps in grasping a picture of large political changes and identifying patterns in current political action affecting the future (Cruz 2015). It also helps in understanding what future perspectives become hegemonic over others and why. The fall of socialist utopias at the turn of the 1980s and 1990s, for example, created room for the rise of a neoliberal, globalised, and technologised view of the future (Milojevic 2005). This neoliberal thinking grew stronger until the recession of the 2000s, after which criticism of the social disadvantages caused by neoliberal economic policies increased, particularly in Latin American countries (Coronil 2011). 
We agree with Masini (1993) that views of future and time are strongly linked to their surrounding cultures and traditions. Several factors, such as experience, and varying philosophical and political traditions and systems, underlie the differing perceptions of the future in our case countries. An understanding of these differences requires knowledge of the countries' own traditions, as these belong to the collective memory affecting present politics and future development (Hoffman 2013). Moreover, some elements of views of the future may have evolved over a long period, and sometimes visions which had little impact originally may have become mainstream (ibid.). This finding is related to the idea of path dependence and increasing returns, where large consequences may result from relatively small or contingent events (Pierson 2000).

The first chapters of this book comprehensively described our project's data. Here, we need to point out that not all the interviews conducted for the project referred to the future. The analysis for this chapter is based on selected national-level interviews in which such references were made: Brazil $(n=22)$; China ( $n=15)$; and Russia ( $n=11)$. With this number of interviews, we of course cannot claim to demonstrate "how educationists in general in Brazil, China, and Russia think about the future of QAE", but our data allow us to reveal the qualitative range of their opinions. In addition to the interview data, we examine the latest plans for education, and especially QAE, put forward in each case country.

Our interview data on the possible futures in the three countries may be characterised as follows: in Brazil, interviewees openly expressed their personal, rather than organisational or official, views, whereas in China and Russia possible futures were mentioned relatively rarely by our interviewees, and such views were expressed in response to questions prior to the explicit futures question at the end of the interview. To some extent, such views have already surfaced in the analyses reported in the book's earlier chapters. As this chapter's analysis shows later, notions of what constitutes "quality of education" and views on QAE are closely interlinked: different conceptions of quality have implications for how quality can and should be evaluated, and conversely, different tools of QAE either prioritise or downplay different notions of quality.

We continue with a review of the changing perceptions of time and future from an historical perspective, including the archetypes of the future of education developed by Inayatullah (2008). Next, we focus on an analysis of the case countries by briefly considering the domestic economic, political, and ideological factors which may affect actors' views of the future development of education QAE. Thereafter, we use our interview and documentary data to analyse how actors in these countries perceive the future trends of QAE in their respective contexts.

\section{Changing concepts of time and different archetypes of the future of education}

Barbara Adam (2010) presents a substantial analysis of how human perceptions of the future have evolved. The earliest conceptions emerged and evolved within religious mythologies which determined the world's future direction 
and the human being's life course. The annual rhythm characteristic of natural economies reinforced perceptions about the cyclical nature of time and the recurrence of the past in the future (Adam 2010). The development of science and technology and the rise of the idea of linear progress represented the fall of myth; the idea of progress guided the search for better utopias and challenged religious providence. People now believed they could influence the future and that they could remould it to suit their needs. The calendar enabled more precise planning, which led to an increase in control, social synchronisation, and regulation. At the same time, paradoxically, the future became more uncertain and contingent, as previously unchallenged traditions of the past ceased to provide answers to future problems (Adam 2010; Ogilvy 2004).

The belief in constant progress has met increasing criticism in recent decades. Ecological devastation, global economic crises, and the failure of socio-political utopias has strengthened the post-modern view that the world and its future cannot be explained by relying on the idea of progress (Adam 2010; Milojevic 2005; Ogilvy 2004). Adam (2010) notes that the future should no longer be considered a "void"; she finds the idea of a conjecture or an "open future" flawed, as present and past generations, through their irresponsible exploitation of nature, have already imposed limits for future generations. Ogilvy (2004) even describes the present enthusiasm for predicting possible futures - various, often conflicting scenarios and future visions - as tragi-comic.

Current prospects, as Milojevic (2005) states, tend to fall into two categories: a firm belief in continued technological development or anxiety about ecological regression leading to natural disaster. However, she cautions against succumbing to such binary utopian or dystopian views. We agree with Milojevic's view that instead of taking a binary approach to the future, it should be considered a heterotopy, where many different, often competing, visions exist simultaneously. These visions are related to values and are continuously negotiated, locally and globally. What some mean by utopia may thus mean dystopia to others.

The theory facilitating this chapter's analysis is Inayatullah's (2008) "futures triangle" and the five archetypal images of the future and the position of education which accompanies it. The futures triangle maps the future in three dimensions: the weight of history, the pushes of the present, and the pulls of the future. Examining historical trajectories in futures research is important, as many of the existing deep structures set the boundaries of future action and change. Likewise, identifying existing trends is important because some of these trends continue and have an influence far into the future. The archetypal images of the future are those which pull people forward (Inayatullah 2008). The archetypes of education futures were inspired by the tradition of research into various future archetypes (see Cruz 2015) and developed in a series of workshops. Although the archetypes are different, they share a common feature in their criticism of the existing education system (Milojevic 2005).

The first archetype believes in constant progress and evolution. It is characterised by a modernist and industrial vision that education should provide basic skills such as mathematics and training for the needs of the economy and the nation-state; it should train consumers, workers, and citizens. 
The second archetype is the opposite of the first and cautions against the collapse of humanity which people will inevitably cause in their continuing excessive exploitation of nature. Humanity has overshot its limits; the future will be worse than the present. This archetype portends growing inequalities among people and deteriorating future conditions. Current education and training provide no remedy for social problems and do not meet a changing world's needs.

The third archetype is idealistic: the world manifests itself as a garden, "Gaia", where cultures are flowers and people's inequality can be socio-technologically fixed. This requires changes in education and training; education institutions should transform themselves from silos of instruction into ecologies of learning pedagogies. Education is idealistic; schools and universities become gardens where students focus on finding their unique skills and learning from each other.

The fourth archetype is globalism: when borders fall, free movement of technology and capital will bring wealth to all. This archetype is opposed to traditional "isms" and dogmas, which it considers as barriers preventing people from achieving a new world. Education prepares individuals for the world of global technology, in which new technologies, global corporations and businesses, and non-governmental actors define frames of reference and rules of action.

The fifth archetype constitutes a counterbalance to the other archetypes by addressing the future nostalgically. A simpler way of life lies ahead, with a clearer hierarchy and less disruptive technologies. The best days have passed, and the changes of the present are too overwhelming. Education should therefore return to its fountainheads, which are filled with basics focusing on morality, clear gender roles, strong leadership (often male), and communitarian values.

In the following section, we apply the futures triangle and the idea of the five archetypes to a reflection of our analysis of QAE in Brazil, China, and Russia. We are especially interested in whether any of these archetypes manifests itself in the country contexts. Based on previous research, we first analyse the historical and political factors which have affected images of future education and QAE development in the three case countries. We then examine how the actors interviewed for this study see the possible future trends of QAE. We also consider the possible futures expressed in the latest national plans for education. These are the National Education Plan 2014-2024 (PNE) in Brazil, the Outline of China's National Plan for Medium and Long-Term Education Reform and Development (2010-2020), and the State Programme for Education Development in Russia (2013-2020).

\section{Perceptions of the future of QAE in Brazil, China, and Russia}

\section{Brazil: education as a national commitment}

\section{Historical weight and pushes of the present}

In Brazil, the contemporary period is felt by many as a transitional stage to the future (Coronil 2011). However, this societal sense of "being in transition" 
is not new. The Brazilian narrative has always depicted the present as a step into the future rather than a continuation of the past or a moment of its own. A few examples of recent official discourses under democracy clearly illustrate this constant reference to an abstract future: in 2011, the legacy of Cardoso (1995-2003) was characterised as "sowing the future" (Graziano 2011); in 2013, ex-President Lula da Silva (2003-2011) told a group of French entrepreneurs "there is no other country with the perspective of the future that Brazil has" (Silva 2013); in 2014, ex-President Rousseff (2011-2016) said that "education is our passport for the future" (Rousseff 2014); in a recent event called "Project Brazil Future", President Temer (2016-present) presented some economic ideas drawn from a programme called "A Bridge for the Future" (n.a. 2015).

Although opinions diverge (Braathen \& Kasahara 2015), Brazil has always characterised itself, and also been characterised, as the land of the future (e.g., Zweig 1941). Early Brazilian history is associated with colonialism and its later history with agrarian oligarchies and dictatorship, which provided no pertinent model for present or future action. The building or fostering of transitional stages to the future through a - frequently rhetorical - discursive construction may be understood as an inherent strategy to discursively break with history. Transitional stages channel attention and effort towards the construction of a better or promising future. This confidence in the future forms part of a set of societal dynamics and socio-cultural features which emerged in, took form in, or permeated Brazilian education history. These shaped the current views of the future in education, as the next section shows.

The Brazilian future has been constantly imagined in connection with the country's socio-economic development. Throughout the twentieth century, a focus on industrialisation, modernisation, and growth permeated every government's political project regardless of its political stance, albeit differently. Although the main goal of these development plans was to attain socioeconomic progress, they always included education concerns, and changes progressively occurred in schooling despite the huge gap between political intention and action. This close discursive connection between education and socio-economic progress allowed education to remain on the political agenda in times of both democracy and dictatorship. Despite the political discontinuity, the democratisation of education, seen in the concrete expansion of education opportunities, continued (Oliveira \& Araujo 2005; Klein 2006; Oliveira 2007; Gouveia \& Souza 2013).

However, the universalisation of education progressed very slowly. There was always significant political interest in education in Brazil, and policy decisions were always based on political rather than public policy reasoning. Governments tended to favour their own political base (Plank 1990) and undertake development plans which reflected these political interests; the place of education in public policy mirrored the political power of the time, which influenced the allocation of public resources to education development (Wjuniski 2013). Education has developed according to governments' ideological stances and political interests (Fonseca 2009). Although the level of political discontinuity was not drastic in the education policies of the last three democratic 
governments (1995-2016), civil society and scholars alike pointed to discontinuity at the level of concrete programmes as a major problem in Brazilian education (e.g., Zarpellon 2011).

Besides governments' own political interests, there have always been ideological and political differences across sectors, political levels, and the country. In the past, although clearly favouring specific societal groups, governments sought certain political compromises (Saviani 1996). Recently, governments have continued this path of seeking compromise through the fostering of democratic forums in which education plans and programmes are discussed. The most important are the National Conferences of Education (CONAE), which gather more than 3,600 participants. The current National Education Plan 2014-2024 (PNE) was outlined in the 2010 CONAE, ratified by the 2014 CONAE, and thereafter legislated. The PNE is thus the result of a broader democratic commitment, which explains its broad acceptance across the education arena.

As Chapter 3 explained in detail, the PNE endorses the use of QAE to achieve quality in education (Brasil 2014; Brasil, MEC/SASE 2014). This largely entails large-scale assessments, as students' performance is considered an important indicator in quality evaluation. The Development Index of Basic Education (IDEB) is perceived as the main Brazilian education quality indicator, and the PNE has restated the IDEB's target of meeting the Organisation for Economic Cooperation and Development's (OECD) Programme for International Student Assessment (PISA) mean score by 2021. Despite the primary focus on indicators, the PNE also envisages other QAE practices. The most significant is a new method of calculating the education budget which regulates the amount spent per student and per year for assuring the minimum standard of quality education (see Centeno, Kauko, \& Candido 2017). This alternative method requires a substantial increase in education funding.

\section{Perceptions of the future}

Inayatullah's archetypes (2008) help in defining Brazilian views by opposition; it explains views which do not seem to belong to the Brazilian culture. This section shows that "collapse" no less than "back to the future" seems far from adequate in defining the Brazilian approach to manifesting or perceiving the future. Neither disenchantment with education nor nostalgia plays a role in the views expressed by Brazilian interviewees. On the contrary, education is now, as always, an important socio-political project whose aims are both individual fulfilment and the country's progress.

Indeed, interviewees were quite hopeful about the future while acknowledging difficulties and limitations. One interviewee aptly remarked that the Brazilian narrative had always been one of improvement (BR-NNGO-04). Most interviewees mentioned the ongoing democratisation of education in Brazil - the progressive focus on school access, dropout and retention rates, and recently on school quality - to justify their confidence in continued future improvement. 
Where recent developments were concerned, they mentioned two favourable factors as crucial for the improvement of education quality. These were the auspicious socio-historical moment and the appropriateness of the PNE. The interviewees considered that the early 2010s represented an auspicious moment for the tackling of education reform. The huge attention paid to education and the concomitant engagement of every sector and level of society in the education debate provided an excellent basis for improving education policy and practice. One interviewee concisely summarised this in saying that in the Brazilian imagination, education would save the country (BR-N-09).

All interviewees viewed the PNE very positively, and all considered it the product of unprecedented collective understanding and commitment. They approved of the PNE's goals and targets and maintained it provided the necessary framework for Brazilian education. Regardless of their room for action or professional profile, all interviewees declared that Brazil had now clearly and correctly defined its education problems and solutions and the paths and directions which should be followed.

Interviewees expressed their views of the improvement of education quality in general; they did not focus only on QAE improvements. QAE was mostly linked with large-scale assessments, which in turn were connected with learning attainments. In their eyes, national evaluation, and the consequent indicators and indexes, belonged to a larger framework, whose main goals were the improvement of education quality and the enhancement of pupils' learning. The intensity or frequency of the relationships articulated between QAE and education quality varied - as might be expected - according to the interviewees' room for action: the more individuals were involved in QAE practices, the more their narrative swung towards the significance of this relationship. Thus, while those in charge of large-scale assessments tended to emphasise QAE, those with no direct connection with QAE practices tended to make only brief narrative incursions into the topic.

What may be unexpected is that, despite criticising the Evaluation System of Basic Education (SAEB) and related indicators and acknowledging its limitations in assessing education quality, all interviewees considered the existing QAE instruments to provide an adequate picture for monitoring quality and equality in Brazilian education. Many considered that it also provided valuable information to guide education practice and education quality improvement policy.

However, QAE practices were mentioned less than other factors connected with education and school quality. Interviewees addressed concrete education developments and tended to elaborate their views based on concrete examples, while addressing broader developments, such as the universalisation of school access, the reduction of inequality, and the need for change in school and teaching culture. In referring to more concrete goals perceived as more attainable, interviewees linked their views to learning achievement and education equality across the country, democratically consolidated and sustainable political processes, appropriate education policy and practice, school conditions, teacher training, working conditions, and teaching quality. 
In brief, QAE practices were only one of many factors interviewees mentioned. Many answered in a quite utopian tone, referring to major or encompassing abstract socio-political and even cultural changes. These references simultaneously conveyed their utopian and dystopian views. One interviewee clearly expressed this by mentioning that numbers helped to identify the "nonlearning" and the dropouts, to whom Brazilians should show no tolerance (BR-N-03). However, this interviewee concluded that this was a dream, corresponding to an education system in which everyone from the school to the federal government committedly fulfilled their own role.

Interviewees' dystopian views were largely linked to a lack of political conditions and real collective agreement on the implementation of practical measures which addressed quality and equality in such an enormous and diverse country. The political discontinuity and divergent positions and views which have converged in the PNE's formulation continue to diverge in its execution. Another common feature mentioned was the slow pace at which changes have occurred and reality has been impacted. Interviewees mentioned that improvement would continue to occur as it had in the past, despite economic and political cycles. However, they foresaw a return to a very slow pace of change.

\section{China: education as a means of rejuvenating the country}

Historical weight and pushes of the present

In China, future visions bear complex semantics inherited from the traditions of philosophical thinking in ancient and imperial times. Hoffman (2013) provides an interesting analysis of how images of the future have changed in China and the effects these changes have had on today's discourses. She points out that different concepts of time have been intertwined and manifested in various ways throughout Chinese history.

Confucian philosophy, which originated around 500 BCE, was founded on a linear concept of time and believed that the future was secured when people, led by rulers and officials, lived up to the highest ethical standards. Confucian teachings proclaimed that the golden age had passed and the imperial rulers should therefore always look to the past in reforming the state. This eventually led to the end of the imperial era, because it provided no tools for the state's regeneration. The new republican government sought influences from the West, providing an impetus to a discourse on the importance of external influences which has continued to this day (Hoffman 2013).

The Chinese Communist Party's assumption of power in 1949 represented a profound change in China's history and its conception of the future. The dismantling of archaic traditions and the later inception of reform became priorities. Mao Zedong's utopian projects, such as the Great Leap Forward and the Cultural Revolution, underlined this approach (Hoffman 2013). Since the late 1970s, China has pursued modernisation without abandoning the one-party 
system. Modernisation, prosperity, the reduction of regional disparities, and the safeguarding of the country's social cohesion have guided Chinese thinking about the future in the last three decades.

China is considered to be standing at a crossroads. The aspiration to influence future development through five-year plans, legislation, and long-term outlines guide societal policies and decision-making (Yang 2014). Futures research is popular and is closely linked to political decision-making and debates. The public approach to the future is generally optimistic, arising from the oneparty system (Callahan 2016). However, the population is ageing, the country's economic growth has slowed, and growth in military spending is the world's largest. The highly educated urban middle class faces a crisis caused by rising prices, and the countryside cannot provide meaningful work. People are weary of the idea of "growth first" (Hoffman 2013).

Current official thinking about the future is crystallised by the Communist Party's slogan the "China Dream". This official future vision was originally presented in a book by Colonel Liu Mingfu, and President Xi Jinping subsequently used it in his inauguration speech. Xi's China Dream seeks the return of China to its natural position as one of the world's leading states, a reference to the country's imperial status in the nineteenth century, when China accounted for about one-third of the entire global market. The Chinese Dream implicitly sees China superseding the USA as the leading economy by 2035. The aim is also to build a moderately prosperous society by the Communist Party's centenary in 2021. Concrete goals are the doubling of gross domestic product, $60 \%$ urbanisation, the building of a space station, and the blueprint for the One Belt One Road Initiative. The Chinese Dream differs significantly from previous harmonious visions of the Chinese future: it is seen more Sinocentric in its endeavour to consolidate China's position internationally (Callahan 2016). Confucianism has enjoyed a robust revival in this wave of nostalgia (Deng 2011).

Hoffman (2013) notes that the China Dream is a vision not of individuals but of the state. She describes how, alongside the formal vision of the future, a vision of the "Chinese Dream" exists which centres on constitutionality, freedom, and democracy. However, although some academic circles and public blogs discuss this vision, it is the view of few Chinese. Moreover, many different influences from ancient and recent history are also present in current Chinese thinking: in recent decades millions of Chinese have turned to spiritual traditions to navigate the future (Hoffman 2013).

\section{Perceptions of the future}

Education, together with science and technology, has become the key means for the restoration of China's leading global position (Postiglione 2015). The idea of rejuvenating the country through science and education was inherited from the Deng Xiaoping era of the 1970s and 1980s and strengthened during Jiang Zemin's presidency in the 1990s and early 2000s (Yang 2014). The idea that education is a means to rejuvenate the nation is also incorporated in 
the Preamble of the Outline of China's National Plan for Medium and Longterm Education Reform and Development (2010-2020) (hereafter "Outline"; $\mathrm{Gu}$ 2010). This document covers every level of education from pre-school to higher education and was created in cooperation with the OECD, the World Bank, and other international actors (Gu 2010). Shanghai's participation in PISA 2006 also provided information for the Outline's preparation (Baird et al. 2016). The document contains several recommendations intended to enhance the quality assurance and evaluation of education.

The Outline includes several strategic goals, two of which are the equality and quality of education. These resemble the main themes of PISA (see Schleicher \& Zoido 2016; Gu 2010). The Outline states that the quality of education should be improved through several measures, such as the reduction of students' workload and the establishment of state standards for urban and, whenever possible, rural schools (Gu 2010; Outline 2010-2020). Subsequent studies have highlighted how the Outline strives for policies which reduce gaps between urban and rural education provision and encourage a transformation from exam-oriented to quality-oriented education (e.g., Yuan 2013). The Outline has boosted curriculum reform, which is a concrete tool for improving the quality of education (Xin \& Kang 2012).

A closer examination of the Outline reveals a contrast between quality education and the measures which guarantee it. The document paints a picture of an expanding monitoring and evaluation apparatus. It stipulates that teachers' qualifications will be improved, teacher recruitment will follow rigorous practices, and the development of evaluation will be continued by setting scientific and diverse benchmarks. Diverse evaluation approaches which help to promote students' development will be explored, student records kept, and the assessment of comprehensive quality developed. Attention is paid to the quality of the supervision system. The Outline stresses that mechanisms for effective supervision at all levels will be established and that schools should "willingly accept and cooperate with legislatures at all levels in supervision and inspection of education law enforcement, and with the personnel sent by law-enforcement agencies on supervision visits" (p. 43).

Actors interviewed for this study were moderately critical but also optimistic concerning future education reform. Some interviewees noted that the lack of independent evaluation authorities and supervisors' lack of expertise slowed the development of quality education. The improvement of supervision was important because supervisors should "possess a capacity to put forward plans to improve schools in the future" (CN-E-07). Some interviewees were critical of education reforms as generally insufficient and focused only on minor structural changes. They anticipated a deepening of urban and rural inequality if thorough measures were not undertaken. Old traditions such as the influence of students' socio-economic background on school choice were deeply rooted in the education system. The greatest challenge lay in the reform of antiquated approaches to learning. 
For the optimists, China's economic and technological development provides the necessary resources to ensure the implementation of evidence-based education and training reforms. Interviewees highlighted the importance of recruiting qualified teachers, the development of teacher training, and the move from exam-oriented education to an emphasis on the child's overall development. Some interviewees placed much trust in the National Assessment of Education Quality (NAEQ); this assessment was believed to enhance the monitoring of not only the teaching and learning process but also results - essentially a control of quality. In this respect, the NAEQ resembles a (social) technology which is believed to solve quality problems in remote areas as well (see Baird et al. 2016).

Although interviewees' opinions on the need for reform seemed harmonious, they differed concerning the pace of measures. Some pointed out that swift political approaches were needed if the disparities between rural and urban areas were not to continue to deepen. Schools are already undergoing "a quiet revolution" (CN-E-07), in which ongoing curriculum reforms aim to reduce students' workload, especially in repetitive memorisation or drilling, and to enhance students' self-regulation and creativity in learning, as PISA encourages (Blackspear 2012; Baird et al. 2016). Other interviewees felt such a fast pace of reform was unrealistic. There were, as one interviewee noted, several factors which might slow the implementation of future QAE reforms, such as challenges related to the decentralisation of the education administration and its separation from the supervision system (CN-E-03).

\section{Russia: appreciation of the national pedagogical tradition and ideas for new development}

\section{Historical weight and pushes of the present}

The historical milestones of Russian futures research are found in the Bolshevik Revolution of 1917 and the dissolution of the Soviet Union in 1991. The Bolsheviks brought a strong future orientation to the Soviet Union's social policy. At its core was Soviet Communism's teleological eschatology, in which the idea of a utopia built by workers led all political activity. Future studies focused on making predictions and assumed an increasingly ideological hue during the Cold War (Bacon 2012).

The collapse of the Soviet Union brought the breakdown of the foundations of Soviet futures research. Although predictions of the Soviet Union's demise abounded during the Cold War, future studies within and outside the country failed to accurately predict the state's collapse. Bacon (2012) describes how futures research worldwide reached its nadir, failing to anticipate the dissolution of the Soviet Union and subsequently of the East European Bloc of socialist countries. In the years which followed, linear predictions were abandoned and interest in multiple scenarios increased. In the last two decades, more than ten divergent scenarios of the future of Russia have been 
constructed, reflecting the political issues which emerged at the time of their drafting (Bacon 2012).

Historical traditions and political changes have contributed significantly to how the future is understood in Russian daily life. According to Schilling (2008), many factors have influenced how Russians perceive their future. These include administrative arbitrariness, a high degree of power distance, late industrialisation, and wide geographical extension. A governance culture in which strategic decisions can be made in a tsarist fashion beyond legislative influence has shaped public views in a direction which makes people feel incapable of influencing their futures (Schilling 2008). Despite late industrialisation, the socialist economy was based on the production of detailed and centralised five-year plans, which were usually over-ambitious. Based on anthropological research, Yurchak (1997) has called the prevailing attitude towards the state's policies "non-involvement and simulated support".

In Russia, official views and presumably also popular thinking about the future have significantly changed since the collapse of the Soviet Union. The socialist utopia has been replaced by various scenarios, the contents of which vary significantly (Bacon 2012). A key feature of Russia's current domestic policy has been its division into conservative or Westernised positions, depending on attitudes towards foreign models and external influences (Johnson 2010). This division has also had implications for perceptions of the future and their interpretation. For example, Russia's political initiatives in recent years, such as proposals for closer cooperation with neighbouring countries, have been interpreted as nostalgic and conservative efforts to restore Russia as the world power it was during the Soviet period. However, as Krickovic (2014) reminds us, analyses of Russian policy should not succumb to overly narrow explanations, because there are many other political factors apart from nostalgia behind recent political initiatives in Russia, such as the unstable international situation, which impels Russia to seek new partners.

Current domestic policy embodies a deep-seated dualism which is significant for Russia's future development. Views are divided between those who advocate sympathy for Western values, European reform, and globalisation and those who see the increasing internal pressure for reform arising from globalisation and Europeanisation as a threat to Russian sovereignty (Johnson 2010; Pavlova 2010; Morgan \& Kliucharev 2012) - a similar division was already a key element in political and cultural debate in pre-Soviet Russia. In Chapter 4, we noted that the influence of international organisations on Russian education policy was relatively limited in the early post-Soviet years and has more recently become even less significant. At the same time, communication between Russian and foreign QAE experts has grown.

Tensions in political decision-making have also affected education policy and its vision for the future. Pavlova (2010) notes that the strategic goals to improve the quality of education and the idea of education as the key to socio-economic development outlined at the beginning of the millennium have never been questioned. However, the dualism mentioned earlier has resulted in a situation 
where goals created at the beginning of the millennium for the development of education and strategies based on them have become a hybrid including both traditional and modern goals, the latter influenced by Western values (see Boguslavskii \& Lelchitskii 2016). As the next section demonstrates, such dualism is reflected in views of the future of QAE.

\section{Perceptions of the future}

The State Programme for Education Development, 2013-2020, is a 700-page document covering all aspects of federally regulated education policy. The programme's overall aim is “to ensure that the quality of education meets people's changing requirements and the development objectives of Russian society and economy". The document outlines a comprehensive and uniform system of QAE based on the "principles of openness, impartiality, transparency, and public and professional involvement". This system will comprise the existing national examinations after grades 9 (the State Final Attestation, SFA) and 11 (the Unified State Exam, USE), and the procedures of independent quality evaluation. The information provided by these national tools will be complemented by Russia's continued participation in international assessments (PISA, Trends in International Mathematics and Science Study (TIMSS), and Progress in International Reading Literacy Study (PIRLS) (Government of Russia 2012: p. 218).

In general, in our comprehensive interview data from Russia, national-level interviewees were more outspoken on the issue of the desired futures of QAE in education, and views on this topic diverged more than they did among interviewees at the local level (the latter are not analysed in this chapter). Many respondents personally indicated that they valued the Soviet and pre-Soviet pedagogical tradition or referred to extensive media discussion of this topic. In this tradition, important elements of QAE are the strong professional autonomy of teachers in the assessment of their students and an emphasis on "upbringing" (vospitanie), which refers to learning's non-cognitive domains. These include moral or "patriotic" education (see Rapoport 2009), which is not measured by international tests or national examinations.

The experts interviewed presented several QAE issues and pondered the solutions leading to new ideas for development. These ideas were not necessarily antithetical to "nostalgic" views - the former might also complement the latter. The notion of education quality embodied in international assessments, especially PISA, was seen as providing a scientific basis for improvement of quality through testing students' problem-solving skills. As a counterbalance, the importance of Russian cultural heritage, which values literature and reading for non-instrumental purposes, was also emphasised (see also Piattoeva \& Gurova 2018). It is noteworthy that the 1998 OECD report on Russia strived for a balance between acknowledging positive aspects of the Russian pedagogical heritage, including assessment practices, and criticising the same pedagogy as unsuited to the needs of a market economy and international competitiveness (OECD 1998: pp. 9, 16, 91, 99-103). 
Some experts argued that assessment should be more independent of teachers, because it was the results of their work that was being assessed. At the same time, there will be a need to familiarise teachers with the new methods of QAE and motivate them to use their results as feedback to stimulate their own professional work. Furthermore, the high-stakes nature of the national examinations at grades 9 and 11 was criticised as narrowing the concept of quality to what the SFA and USE measured. Instead of focusing on only one type of uniform measurement of learning, there should be a diversified system of QAE which comprised both quantitative and qualitative components (such as essays and portfolios), covering a wide range of learning domains in the curriculum and extracurricular activities. The experts who voiced an opinion on the ranking of schools based on QAE results and the resulting competitive atmosphere did not question it as such but called for more analysis of differences in learning achievement between schools and regions which would make it possible to devise corrective measures to support low-achievers.

\section{Conclusions}

Our analysis has shown that history sets boundaries but also provides sources of political legitimation to the three countries' future imaginaries. Based on the data from Brazil, it can be stated that there is no symbolic period in the history of the country in which interviewees or the examined documentary material locate the future. In contrast, the Chinese authorities, in justifying future projects, appear to rely on the nostalgic idea of restoring the status the country has lost. The data on Russia also suggest that the recent past has coloured ideas of the strengths of Soviet and pre-Soviet pedagogy. However, the nostalgic Chinese and Russian views differ substantially in their semantics from the fifth archetype described at the beginning of this chapter; instead of looking back to traditional or simpler forms of education, the value placed on national traditions in China and Russia is combined with the ambitious aim of improving the quality of the national education systems.

In examining the current factors affecting the images of future developments of education and QAE in the three countries, we found that education has been regarded as a central tool for socio-economic development, especially in Brazil, regardless of transfers of power. In Russia, the need for continuing education reforms is generally acknowledged, although views on how such reforms are implemented vary. In China, rapid economic growth and an understanding of education as its key element have contributed to the universalisation of basic education and projects to improve the quality of education. However, circumstances and trends such as political discontinuity in Brazil, administrative arbitrariness in Russia, or the rigidity of governance and legislation in China are features which continue to complicate education's future directions.

Along with history and present circumstances, the future is influenced by many often concurrent and rival views, which are often presented in the forms of plans, scenarios, or visions. These views could be conceived of as factors 
which "pull" human beings towards particular futures. The archetypes presented at the beginning of this chapter attempt to categorise some initial views of education futures, which, instead of a strict theoretical framework, serve as a reflective basis for this chapter's analysis (Inayatullah 2008). Future research on QAE in education is especially challenging from this perspective, because the core of the education system is people's ability to acquire new knowledge and on this basis to influence future trends and the emergence of new societal ideas.

In searching our data, we found that Brazilian views reflected a combination of several archetypes. While "evolution and progress" is the main - implicit and explicit - stance in Brazilian political and social culture (the Brazilian flag's motto is "order and progress"), its justification is most frequently tied to idealistic education and social ideals ("Gaia"). If we understand "globalism" as conveyed by international QAE practices and policies, and as the expected and desired growing participation of civic society in education debates and decisions, it might be said that in addition to the intersection of the first two archetypes - which largely define the Brazilian views - globalism is also gradually shaping the Brazilian imaginary.

In China, as previous research suggests, visions expressed at the state level may differ significantly from individual views of the future. The experts interviewed for this study shared their views on the need to reform school curricula and develop schools as modern institutions, the purpose of which was to promote the overall development of children and adolescents. Continuous development and progress is also the thread of the current national Outline. However, the idea of education as a source of national rejuvenation reflects a nostalgia stated in the Outline but which was not communicated by the Chinese interviewees. Although it is impossible to exhaustively demonstrate any competing or deviating images of the future based on a small number of interviews, our analysis suggests that the views of the interviewed experts on the current state and future of QAE in education, especially on the supervisory system, differs from the stipulations of the Outline. Furthermore, the globalist archetype of the future seems unfamiliar in the Chinese context, although China is actively seeking to identify best practices abroad and has lowered the threshold for cooperation with international actors. Nor was the idea of schools as gardens of learning reflected in responses in the Chinese documents and interviews analysed in this study. However, this does not mean that the idea of learning as a garden is not present elsewhere in Chinese education thinking; the metaphor of the teacher as a gardener dedicated to his or her work is common in China.

The theme arising from our Russian data centred on two opposing, or as this research suggests, somewhat complementary forces: Western assessment systems measuring quality as cognitive competences and the survival of the pedagogical and moral education developed in pre-Soviet and Soviet times. The Russian interviewees reflected on how the education system might be developed in a balanced way, with traditional values and new methods for evaluating learning achievements complementing each other. They emphasised that the development of education should not focus only on one-sided instrumental or 
cognitive learning and the evaluation of learning outcomes but also on the cultural and moral upbringing of children and youth. Thus, nostalgia in Russian education does not seek a return to previous systems; rather, it seeks to retain some elements considered important in national curricula, teaching, and QAE practices. In emphasising the importance of educating civilised individuals and the significance of non-cognitive learning outcomes, the ideals of the Russian education system seem closer to those of the Brazilian system than those of the Chinese system.

Altogether, our study showed that even if only some of the archetypes or their variants can be found in the research data, examining them may help to distinguish new nuances, issues, and views which may affect education's future policies and governance.

\section{Bibliography}

Adam, B. (2010). History of the future: Paradoxes and challenges. Rethinking History, 14(3), 361-378.

Américo de Figueiredo Porto, C., Marques, E., \& Befort Andrade Santos, A. (2010). Prospective in Brazil: The power to build the future. Technological Forecasting \& Social Change, 77, 1550-1558.

Andersson, J. (2012). The great future debate and the struggle for the world. American Historical Review, 117(5), 1411-1430.

Andersson, J., \& Rindzevičiūte, E. (Eds.). (2016). The Struggle for the Long-Term in Transnational Science and Politics: Forging the Future. New York, NY \& London: Routledge.

Bacon, E. (2012). Writing Russia's future: Paradigms, drivers, and scenarios. Europe-Asia Studies, 64(7), 1165-1189.

Baird, J.-A., Johnson, S., Hopfenbeck, T. N., Isaacs, T., Sprague, T., Stobart, G., \& Yu, G. (2016). On the supranational spell of PISA in policy. Educational Research, 58(2), 121-138.

Biesta, G., \& Osberg, D. (2010). Complexity, education and politics from the inside-out and the outside-in: An Introduction. In D. Osberg \& G. Biesta (Eds.), Complexity Theory and the Politics of Education (pp. 1-4). Rotterdam: Sense Publishers.

Blackspear, S. (2012). The policy impact of PISA: An exploration of the normative effect of international benchmarking in school system performance (OECD Education Working Papers, No. 71). Paris: OECD.

Boguslavskii, M. V., \& Lelchitskii, I. D. (2016). Modern development strategies of the Russian education in the conditions of the information society. SHS Web of Conferences, 29, 01010 .

Braathen, E., \& Kasahara, Y. (2015). Brazil, land of future? Conservative development strategy and urban challenge. In A. Hansen \& U. Wethal (Eds.), Emerging Economies and Challenges to Sustainability: Theories, Strategies and Local Sustainabilities (pp. 135-148). London \& New York, NY: Routledge.

Brasil, Câmara dos Deputados. (2014). Plano Nacional de Educação 2014-2024, Lei n. 13.005, de 25 de Junho de 2014, que aprova o Plano Nacional de Educação (PNE) e dá outras providências. Atualizada em 1/12/2014 [National Plan of Education 2014-2024, Law no. 13.005, 25 June 2014, which passes the National Plan of Education (PNE) and provides other guidelines. Updated on 1 December 2014]. Brasília: Câmara dos Deputados, Centro de 
Documentação e Informação, Coordenação Edições Câmara. Retrieved from www.plan alto.gov.br/ccivil_03/_ato2011-2014/2014/lei/113005.htm

Brasil, Ministério da Educação/Secretaria de Articulação com os Sistemas de Ensino (MEC/ SASE). (2014). Planejando a Próxima Década: Conhecendo as 20 Metas do Plano Nacional de Educação [Planning the Next Decade: Knowing the 20 Goals of the National Plan of Education]. Retrieved August 25, 2016, from http://pne.mec.gov.br/images/pdf/pne_con hecendo_20_metas.pdf

Bussey, M., Inayatullah, S., \& Milojevic, I. (Eds.). (2008). Alternative Educational Futures: Pedagogies for Emergent Worlds. Rotterdam/Taipei: Sense Publishers.

Cairney, P., \& Geyer, R. (2015). Introduction. In R. Geyer \& P. Cairney (Eds.), Handbook on Complexity and Public Policy (pp. 1-15). Cheltenham: Edward Elgar Publishing.

Callahan, W. (2016). China 2035: From the China dream to the world dream. Global Affairs, 2(3), 247-258.

Centeno, V. G., Kauko, J., \& Candido, H. H. D. (2017). Quality assurance and evaluation through Brazilian lenses: An exploration into the validity of umbrella concepts. Comparative Education, published on-line. Retrieved from http://dx.doi.org/10.1080/03050068. 2017.1348084

Coronil, F. (2011). The future in question: History and Utopia in Latin America (19892010). In G. Calhoun \& G. Derluguian (Eds.), Business as Usual: The Roots of the Global Financial Meltdown (pp. 231-292). New York, NY \& London: New York University Press.

Cruz, S. O. (2015). Alternative futures of global governance: Scenarios and perspectives from the Global South. Foresight, 17(2), 125-142.

Deng, Z. (2011). Confucianism, modernization and Chinese pedagogy: An introduction. Journal of Curriculum Studies, 43(5), 561-568.

de Oliveira, R. P., \& de Araujo, G. C. (2005). Qualidade do ensino: uma nova dimensão da luta pelo direito à educação [Educational quality: A new dimension of the struggle for the right to education]. Revista Brasileira de Educação, 28, 5-23.

Fonseca, M. (2009). Políticas públicas para a qualidade da educação brasileira: entre o utilitarismo econômico e a responsabilidade social [Public policies for the quality of Brazilian education: Between economic utilitarianism and social responsibility]. Cadernos CEDES, 29, 153-177.

Gouveia, A. B., \& de Souza, Â. R. (2013). Efetividade da política para o ensino fundamental em municípios Brasileiros [Policy effectiveness for elementary education in Brazilian municipalities]. Cadernos Pesquisa, 43(150), 836-855.

Government of Russia. (2012). Gosudarstvennaia programma Rossiiskoi Federatsii "Razvitie obrazovaniia" na 2013-2020 gody [State programme of the Russian Federation "Development of education" for 2013-2020]. Retrieved December 10, 2016, from http://gov ernment.ru/en/docs/3342

Graziano, X. (2011). Semeando o futuro: 80 medidas estruturantes do governo FHC [Sowing the future: 80 structuring measures of FHC government]. Fundação Fernando Henrique Cardoso. Retrieved May 11, 2017, from http://fundacaofhc.org.br/files/pdf/80-medidasestruturantes-governo-fhc.pdf

Gu, M. (2010). A blueprint for educational development in China: A review of "The National Guidelines for Medium- and Long-Term Educational Reform and Development (2010-2020)". Frontiers of Education in China, 5(3), 291-309.

Hoffman, J. (2013). China's search for the future: A genealogical approach. Futures, 54, 53-67.

Inayatullah, S. (1990). Deconstructing and reconstructing the future: Predictive, cultural and critical epistemologies. Futures, 22(2), 115-141. 
Inayatullah, S. (2008). Mapping educational futures. In M. Bussey, S. Inayatullah, \& I. Milojevic (Eds.), Alternative Educational Futures: Pedagogies for Emergent Worlds (pp. 13-39). Rotterdam/Taipei: Sense Publishers.

Johnson, D. (2010). Educational reform in Russia: Culture, context and worldview. In D. Johnson (Ed.), Politics, Modernisation and Educational Reform in Russia From Past to Present (pp. 7-16). Southampton, Oxford Symposium Books.

Klein, R. (2006). Como está a educação no Brasil? O que fazer? [How is education in Brazil? What to do?] Ensaio: Avaliação de Políticas Públicas Educacionais, 14(51), 139-172.

Krickovic, A. (2014). Imperial nostalgia or prudent geopolitics? Russia's efforts to reintegrate the post-Soviet space in geopolitical perspective. Post-Soviet Affairs, 30(6), 503-528.

Lula da Silva, L. I. (2013). n.t. [Lula da Silva speech to French entrepreneurs on the 21 March 2013, French consular residence]. Retrieved May 11, 2017, from https://saopaulo. consulfrance.org/Ex-presidente-Lula-convidado-de ; full speech in: www.institutolula. org/nao-existe-nenhum-pais-com-a-perspectiva-de-futuro-que-o-brasil-tem-diz-lula-aempresarios-franceses

Masini, E. B. (1993). Why Future Studies? London: Grey Seal.

Milojevic, I. (2005). Educational Futures: Dominant and Contesting Visions. London \& New York, NY: Routledge.

Morgan, W. J., \& Kliucharev, G. A. (2012). Higher education and the post-Soviet transition in Russia. European Journal of Education, 47(1), 3-8.

n.a. (2015). Uma ponte para o futuro [A bridge to the future], Brasília, 29 de Outubro de 2015. Fundação Ulysses Guimarães/PMDB. Retrieved May 11, 2017, from http://pmdb. org.br/wp-content/uploads/2015/10/RELEASE-TEMER_A4-28.10.15-Online.pdf

OECD. (1998). Review of National Policies for Education - the Russian Federation. Paris: OECD.

Ogilvy, J. (2004). Creating Better Futures: Scenario Planning as a Tool for a Better Tomorrow. New York, NY: Oxford University Press.

Oliveira, R. P. d. (2007). Da universalização do ensino fundamental ao desafio da qualidade: uma análise histórica [From the universalisation of elementary education to the challenge of education]. Educação \& Sociedade, 28(100), 661-690.

Outline of China's National Plan for Medium and Long-Term Education Reform and Development. (2010-2020). Retrieved May 29, 2017, from http://planipolis.iiep.unesco.org/ sites/planipolis/files/ressources/china_national_long_term_educational_reform_develop ment_2010-2020_eng.pdf

Pavlova, M. (2010). The modernization of education in Russia. In D. Johnson (Ed.), Politics, Modernisation and Educational Reform in Russia From Past to Present (pp. 59-70). Southampton: Oxford Symposium Books.

Piattoeva, N., \& Gurova, G. (2018). Domesticating international assessments in Russia: Historical grievances, national values, scientific rationality and education modernization. In C. Alarcón \& M. Lawn (Eds.), Assessment Cultures: Historical Perspectives (pp. 87-110). Frankfurt am Main: Peter Lang.

Pierson, P. (2000). Increasing returns, path dependence, and the study of politics. The American Political Science Review, 94(2), 251-267.

Plank, D. N. (1990). The politics of basic education reform in Brazil. Comparative Education Review, 34(4), 538-559.

Postiglione, G. A. (2015). Research universities for national rejuvenation and global influence: China's search for a balanced model. Higher Education, 70(2), 235-250.

Rapoport, A. (2009). Patriotic education in Russia: Stylistic move or a sign of substantive counter-reform? The Educational Forum, 73(2), 141-152. 
Rousseff, D. (2014). Dilma afirma que educação é passaporte para futuro do Brasil [Dilma affirms that education is the passport for Brazil's future]. In Luciano (Ed.), No café com a Presidenta. Retrieved May 11, 2017, from www.brasil.gov.br/educacao/2014/01/ dilma-afirma-que-educacao-e-o-passaporte-para-o-futuro-do-brasil

Saviani, D. (1996). Política e Educação no Brasil [Policy and Education in Brazil] (3rd ed.). Campinas: Cortez/Autores Associados.

Schilling, E. (2008). Future concepts in Russia and Germany: Different approaches to planning in the global society. Twenty-First Century Society, 3(2), 131-142.

Schleicher, A., \& Zoido, P. (2016). The policies that shaped PISA and the policies that PISA shaped. In K. Mundy, A. Green, B. Lingard, \& A. Verger (Eds.), The Handbook of Global Education Policy (pp. 374-384). Chichester: John Wiley \& Sons.

Slaughter, R. (2002). Futures studies as an intellectual and applied discipline. In J. A. Dator (Ed.), Advancing Futures: Future Studies in Higher Education (pp. 91-108). Westport: Praeger.

Wjuniski, B. S. (2013). Education and development projects in Brazil (1930-2008): Political economy perspective. Brazilian Journal of Political Economy, 33(1), 146-165.

Xin, T., \& Kang, C. (2012). Qualitative advances of China's basic education since reform and opening up. Chinese Education and Society, 45(1), 42-50.

Yang, L. (2014). Implementation of China's rejuvenation through knowledge. In K. Shao \& X. Feng (Eds.), Innovation and Intellectual Property in China: Strategies, Contexts and Challenges (pp. 53-79). Edward Elgar Publishing: Cheltenham.

Yuan, Z. (2013). China: Promoting equity as a basic education policy. In Y. Wang (Ed.), Education Policy Reform Trends in G20 Members (pp. 359-375). Berlin: Springer-Verlag.

Yurchak, A. (1997). The cynical reason of late socialism: Power, pretense and the Anekdot. Public Culture, 2(9).

Zarpellon, S. C. (2011). Continuidade e descontinuidade administrativa de programas e projetos econômicos e sociais: um ensaio sobre fatores que contribuem para esse fenômeno na região centro-sul do Paraná, Brasil [Administrative continuity and discontinuity of economic and social programmes and projects: An essay about the factors that contribute to the phenomenon in the south-central region of Paraná, Brazil]. In III Congresso Iinternacional de Educação de Ponta Grossa. Anais do CIEPG (Vol. 1, pp. 1-18). Ponta Grossa: UEPG. Zweig, S. (1941). Brazil: Land of the Future. New York, NY: The Viking Press. 


\title{
9 Conclusion
}

\author{
Jaakko Kauko, Risto Rinne, and Tuomas Takala
}

\section{Introduction}

The preceding chapters analyse the politics of quality in education in Brazil, China, and Russia. It has become clear that our premise that quality is the most important framing factor in education is correct. In initiating this research project, we acknowledged the claims previous studies have made about this issue. The shared mind-sets of international organisations' personnel and schoolteachers, who are almost obsessed with quality assurance and evaluation (QAE) whether they view it positively or negatively, confirm the earlier hypothesis. We take this a step further, arguing that it is more accurate to suggest that it is QAE itself, rather than quality, which has become the central framing factor of education policy.

In Chapter 3 we took issue with the historical development of this change. Although different paths to the use of QAE in education are taken, all involve cooperation with international organisations and find it possible to use QAE as an ostensible solution to various problems. In addition to the international organisations' influences, as we pointed out in Chapter 4, to varying degrees, there are also transnational influences via expert networks. Although these three countries have built up their QAE capacity, they have created more room for experts, who are more transnationally oriented in their work. In Chapter 5, we discussed the potential tensions between experts and politicians arising from their different operational logics.

Our research touched on QAE procedures and their concrete work in the socio-political and historical context. As Chapter 2 discussed, in attempting to conduct our research systematically, we glimpsed the everyday reality around the questions of quality in education. As the empirical work progressed, we were able to identify how all the flows of QAE data were described as involving friction at every stage: production, availability, and use (Chapter 6). Moreover, the closer we got to the local level in Chapter 7, the more complex it became in relation to the visions of the transnational QAE agenda Chapter 1 described. Although the frictions of data produced something new (Chapter 6), it became clear that the schools which opposed change found themselves in the most difficult position (Chapter 7). To come full circle, interestingly, future aspirations 
of QAE in education are strongly linked to the past (Chapter 8), which begs the question of what this study can teach us.

The epistemological premise of this book is the idea of complexity and contingency. During the many analysis tracks described in Chapter 2, our aim was always to try to understand and comprehensively compare the dynamics of the politics of quality in education in Brazil, China, and Russia. Indeed, there is an internal paradox in our analysis, akin to that of comparative education as a field of enquiry. On one hand, throughout our analysis, we can observe the totality of the QAE agenda, and, if we think sufficiently abstractly, we can see and construct similarities in it across different contexts. On the other, we witness a range and plurality of solutions and use of room for action at different levels, especially at the local. Understanding this comparative paradox has been the goal of our analysis of these dynamics.

In Chapter 1, we questioned the idea of transfer. Our comparative paradox sheds light on identifying the inherent problems of the idea of transfer, even asking, "Should we look for differences or similarities?" We can say there is both a clear policy transfer in the transnational QAE agenda and that there is not. They exist at the same time, like Schrödinger's cat, in a box with a potentially deadly trap, and the outcome is left to probability. However, if we think of causality more in the sense of complexity theories, the conclusion that both ideas co-exist becomes more reasonable. As we argued in Chapter 1, it can be deduced that causality is always a question of probability. The existence of the transnational QAE agenda increases the probability that QAE governance tools will be implemented, yet local conditions create probabilities (path dependencies) which steer events in different directions. This chaotic arrangement creates the conditions for various dynamics.

\section{Three dynamics}

We argue that three dynamics can be discerned in Brazil, China, and Russia:

- Quality assurance and evaluation (QAE) rather than quality itself has become the objective of education policy. While quality of education remains undefined and contested, QAE becomes the concrete, defined, must-do in education and remains uncontested. This is constituted in a dynamic of "shared and self-reinforcing goal-setting".

- The QAE toolbox does not produce quality as such but rather works as a means of controlling the provision of education. From the state's geopolitical role in the global field to the local understandings of governance, QAE is an attempt to tease out desired aspects from the education system which are not always connected with education. Regardless of this powerwielding aspect, implementation itself is multifaceted and frequently transnational. We call this dynamic "authorising but diverted governance".

- In the third dynamic, we find that QAE both destabilises and reorganises actor roles. What is interesting here is that state actors, for example, can 
easily use quality to establish their position, but then find that opening the QAE toolbox can lead to the destabilisation of the status quo in the newly available space for politicking. We call this "destabilising and reorganised role-setting".

Table 9.1 summarises these dynamics, which are discussed in more detail in the following sub-sections, with some references to our research published elsewhere. Each dynamic reflects the dimensions of CADEP (Chapters 1 and 2) and at the same time attempts to illustrate the moving nature of politics. The third dimension of politicking is the defining term for the other two dimensions, as it describes the movement which occurs in the room for action (self-reinforcing, authorising, destabilising) and is symmetrically ("and") or asymmetrically ("but") related to the other attributes. The political situation describes the polity's construction (shared, diverted, reorganised). The political possibilities describe what the target of action is or what is considered the addressed problem or solution (goal-setting, governance, role-setting) (see Simola et al. 2017). We examine each of these dynamics in the following sub-sections.

\section{Self-reinforcing and shared goal-setting: $\mathrm{Q} A E$ not quality}

We have already indicated that QAE is on the agenda of international organisations, usually emphasising the connection between education and economic growth, and the need for QAE procedures in education to make successful policy to reach their education aims (e.g., Chapter 1). In Chapter 1, we questioned this claim, especially the potential for clear top-down rational decision-making based on data. Regardless of this critique, we have found that QAE functions as a governance tool which creates a self-reinforcing dynamic, in which the need for quality and the need for QAE converge and problems and solutions are mingled.

The QAE agenda is shared and embedded in webs of actors. In Chapter 4, we argued that the role of international organisations in policy discussions and decisions is clearly variable between our case countries and across time. Contrary to a straightforward policy-transfer notion, our findings show that similarities between local authorities' and international organisations' advice and the problematisation of QAE and the design of QAE tools at national levels do not necessarily prove a cause-and-effect relationship. Any conclusions on

Table 9.1 Dynamics in the politics of quality in Brazil, China, and Russia

\begin{tabular}{lll}
\hline $\begin{array}{l}\text { Politicking: How is the } \\
\text { room for action used? }\end{array}$ & $\begin{array}{l}\text { The political situation: What is structurally } \\
\text { possible for the constellation of actors? }\end{array}$ & $\begin{array}{l}\text { Political possibilities: What } \\
\text { is considered possible? }\end{array}$ \\
\hline \begin{tabular}{lll} 
Self-reinforcing & and shared & goal-setting \\
Authorising & but diverted & governance \\
Destabilising & and reorganised & role-setting \\
\hline
\end{tabular}
\end{tabular}


this question are complicated by the differing views of key actors on "who influenced whom and by how much". However, it is still correct and relevant to speak of a transnational QAE agenda as a network, embodying complex and changing relationships between various actors.

When applied to the general education politics of the three countries, the picture becomes more nuanced. Based on document analysis of the Organisation for Economic Cooperation and Development (OECD) and the World Bank, we have established that these organisations give Brazil, China, and Russia the same advice, suggesting they take QAE as a guide for policymaking, with the occasional addition that teachers' incentives should be connected to performance (Takala et al. 2018). This agenda has been adopted relatively well in all three countries but always with national emphases. Although it yearns for some elements of Soviet pedagogy (Chapter 8), the Russian national education agenda has changed its justification for QAE from the immediately post-Soviet aims of democratisation and school autonomy to the securing of national economic growth and global competitiveness (Gurova, Piattoeva, \& Takala 2015). The Chinese quality education reform has followed the transnational agenda, based on the idea that testing and evaluation are key to the achievement of quality, and international large-scale assessments are viewed positively (Suominen et al. 2017; Chapter 4). The Brazilian political and academic elites have been connected to international trends in times of political and economic stability and instability; QAE policies have mirrored global tendencies (Kauko et al. 2016). However, Brazilian QAE discourse is coloured by social terminology such as "social quality" (Centeno, Kauko, \& Candido 2017). Interestingly, in Chapter 8, we have been able to indicate that these aspirations are also projected into the future, tightly connected with QAE, which promises longevity for the shared agenda. We can at least conclude that QAE has proven an attractive governance tool.

The agenda feeds a self-reinforcing dynamic. As we hinted at this chapter's start, our research supports the argument that the technical process of measurement rather than the quality of education itself has become one of the main aims of education policy. In Chapter 6, we demonstrated that QAE data fail to give the kind of directions to policy or pedagogy which their producers claim. The use of data itself becomes a game, based on the "dynamics of trust and distrust". This is also seen at the local level, where there is little possibility to avoid QAE but where little use is seen in data collection (Chapter 7). The question of the nature of quality in education becomes side-lined in the process of its implementation. The results of this project, reported elsewhere, indicate that standardised testing feeds a need for more testing (Piattoeva \& Saari 2018) and that quality becomes simultaneously a means of problematising education and providing a solution for it (Minina et al. 2018). In Chapter 7, we also pointed out that the schools which opposed QAE reforms faced the most difficult challenges.

Based on our work, we can say that QAE is a global phenomenon and a shared goal, and we have observed that it penetrates practice at global, national, 
sub-national, and local levels. It should be remembered that this is not to say anything, yet, of the multiple direct and indirect consequences of QAE for education practice. The politics of quality bears a self-reinforcing dynamic which its actors largely share. Some critical rhetorical questions thus arise. If the lack of quality can be addressed only through more QAE, when is the promise of quality finally realised? Are we in an endless loop of planning an increasingly stringent, effective, all-encompassing system which will provide better evidence for decision-making?

\section{Authorising but diverted governance}

Due to the widespread view of how QAE education processes help to boost the quality of education and consequently the economy, the implementation of QAE confers much legitimacy. In policymaking, QAE data are used to legitimise decisions, a phenomenon extensively studied in comparative education and other research strands. In our study, instead of merely serving to legitimise, we found that transnational and national expert networks gained more room for action seeking justification with the help of QAE data. However, as in the previous dynamic, the implementation of governance seldom follows the original plan.

Authorisation happens on different scales. Brazil, China, and Russia have gradually gained greater geopolitical prominence and self-confidence. This is manifested in their decreasing dependency on international funding since the 1980s and 1990s, their growing roles in international organisations, and their increased transnational cooperation (Chapters 3 and 4). Geopolitical change was by no means due to QAE; rather, its new, more powerful role could also ensure more finely tuned governance, drawing on growing economic capacity and, arguably, more articulate global aims.

Chapter 3 traced the backdrop to the newly shaped political situation and its facilitation and restriction of the creation of QAE systems between the mid1980s and the mid-1990s. There was an opportune moment for the introduction of QAE in each context. The construction of Brazilian QAE combined problematic school expansion, federalism, decentralisation, and democratisation, at which point a QAE system seemed a feasible solution to govern a complex and politically delicate education system. Similarly, democratisation in the totally different post-Soviet context can be argued to have been a catalyst in Russia, but the system fragmented more dramatically because of marketisation, the devolution of central power, and education financing. This was an opportune moment for international organisations to introduce their perspective. In China, economic growth was seen as contingent on education and there was a longer tradition of QAE. In each context, international organisations' presence supported reforms in shaping the agenda.

QAE offered an apt solution at the historically opportune moments of democratisation and the state's crisis of legitimisation or its attempts to curb the effects of decentralisation. At such moments, international organisations and 
cooperation helped to introduce QAE as a solution (Chapter 3). QAE was a key tool in steering this development and inserting general political aspirations into the education system. It is thus interesting to ask whether QAE has served the quality of education or the need to control. These two are not mutually exclusive, but the internal logic is that quality can only happen through tighter control.

As we have already established, there were variations in the different countries; reactions relate to the longer course of history in each context. In line with the transnational QAE agenda and drawing on the Soviet planning tradition, the expert community in Russia treats the "science of testing" in positivist terms and sees it as a valuable method for understanding social phenomena (Piattoeva \& Gurova 2018). Although Brazilian experts' connections with international actors have been clear for decades, neither the idea of imposition nor regional factors seem likely causes of variation based on our review but rather the local relearning of QAE techniques (Kauko et al. 2016): Brazilian education policy has adopted practices from the global QAE agenda but has reflected the underlying ideology (Minina et al. 2018). The Chinese case is more nuanced, as shown in Chapters 4 and 5: experts can find some room for action, but the state authorities monitor their action more closely.

Various questions of authorisation arise in expert communities' room for action. Chapters 4 and 5 point to how expert communities are well-networked transnationally at the same time as they negotiate the area of their operation. For example, Russian experts are supportive of the QAE technology of the international organisations conducting international comparative assessment studies, while gaining authority and legitimacy for themselves. At the same time, they explicitly attempt to link international studies to the national context (Piattoeva \& Gurova 2018). Experts also express views rooted in domestic pedagogical traditions, including QAE practices, indicating a wish to retain what they see as valuable in these traditions (Chapter 8). The grip of state authority on expert communities has somewhat weakened in China and Russia, while such control in Brazil has been almost absent. In all countries, the influence of expert communities has grown in ways policymakers have not always predicted. QAE's prominence in the education agenda enables expert communities to strengthen, because experts are among the few actors capable of producing data, the core commodity for sustaining the QAE system.

The implementation of QAE gets more diverted than meets the decisionmaker's eye. Criticism of the theoretical notion of governance at a distance the replacement of formal prescription with subjects' "voluntary" commitment to accountability through performance evaluation - was not among our initial premises. However, in the course of our research, it became increasingly obvious that this notion, typically formulated with reference to education policy developments in European countries, is a flawed perspective for an analysis of QAE as a model of governance in our case countries (which may or may not apply in other contexts). Our analysis has shown that as the interests of different groups of actors in how they react to QAE tools diverge or even collide, the 
aim of governance at a distance is only partly achieved in education practice or sometimes not at all.

\section{Destabilising and reorganised role-setting}

Our study found that QAE created new roles and changed old ones in different scales of operation. One of the key dynamics in the politics of quality in education thus lies in QAE's contribution to both destabilising and buttressing actor roles.

Chapter 4 sought an understanding of actor constellations in national political arenas and their connection with changes in the QAE infrastructure. Differences in this reorganisation emerged between the Brazilian case, where a large body of third-sector organisations had mobilised, and the less dynamic arenas of China and Russia. QAE has the potential to liberalise and marketise education because feedback channels from the education system are open and the formation of new civic actors proliferates to provoke debate and spark new movements. As Chapter 5 pointed out, this is clearly not the case in China and Russia. However, as Chapter 4 demonstrated, even in China and Russia, we could observe the expert communities' growing transnational networking. In relation to these countries' rising geopolitical aspirations, there is a tendency to curtail the significance of international organisations at the national level. These countries have been able to strengthen their steering of international organisations on quality in national education, while new actor constellations have created new degrees of instability, even if such instability is less marked in China and Russia.

As we concluded in Chapter 5,

Policymakers' and experts' basic relationship with assessment data use differs. Whereas policymakers can work with or without data, experts depend on it. Whereas policymakers can bend interpretations, experts attempt to adhere to what is analysed. Experts' independence from state organs is another important issue. These differences in understanding data use also reflect the basic dynamic of the relationship between the state and experts.

The destabilising potential of politicking may be seen in QAE's influence on the latent conflicts between state and experts. Experts do not aspire to the role of political decision-makers, but they may be uneasy about how policymakers use data. However, policymakers understand the power of QAE data and the need to control its use (see Chapter 5).

In Chapter 7, our analysis of the effects of QAE on relations between local authorities and schools added a combination of governance theories and organisational analysis to our theoretical perspectives, to provide a better understanding of how QAE mechanisms could both provide and limit schools' access to new sources of power. While the comparative analysis of local education 
practitioners added to the critique of the simplistic notion of governance at a distance, it went further by uncovering the diverse ways in which QAE policies can enhance and change local governance and outlined the potential room for action of schools subjected to performance evaluation. This room for action was more complex than "adaptation" or "resistance": some consequences and results had no connection with the original purpose.

It is clear the data being collected also have consequences for schools' position in a societal setting so complex that school-level actors see them not only as evidence for decision-making but as a game in which their own working conditions or moral choices are at stake. In this sense, QAE works according to a dynamic in which the schools seek to perform to governance, governance seeks to perform to policymakers, and policymakers seek to perform to their international and national peers and the public. This may also be seen as a regular accountability chain. However, we have already argued that QAE power at the local level eventually changes actor relations, albeit not uniformly, as Dahler-Larsen (2012) predicted. This, and the fact that all data flows include friction and productive power (Chapter 6), raises the question of QAE's actual efficacy as a governance tool.

As our research findings in Chapter 7 indicated, the local picture of the different actor roles in education is unsurprisingly complex. Russia is a good example of layeredness, whereby a mixture of different QAE models has prevailed during different periods. In the Russian case, ascribing change as convergence towards the West is therefore questionable. For example, as a Soviet legacy, equality of access remained a major principle in policy discourse and a legitimation of QAE (Gurova 2017). Nevertheless, surveillance techniques are being expanded in Russia with the help of equality discourse and merged with more traditional QAE practices (Piattoeva 2018). The Russian data suggest the local level suffers from the increased bureaucratisation of school work resulting from current education governance, which aims to account for everything (Gurova 2017). Russian teachers face a series of moral questions regarding the effects of QAE, in which policy and professional integrity are juxtaposed (Gurova \& Piattoeva 2019). In the face of the multiple QAE techniques in use in Brazil (Kauko et al. 2016), schools may adopt different positions towards the intended control (Candido et al. submitted). In China, increased control has also increased the implementation responsibilities at the local level (Suominen et al. 2017). Although there are ways in which control is legitimised, there are serious degrees of destabilisation in local-level actors' work.

As researchers, we have had to come to terms with the destabilising potential embedded in QAE. In Chapter 2, in examining our research, we noted that we could learn something of QAE through the research process itself. It seemed that our participants reacted to our QAE research much as they would to QAE procedures themselves, either seeing it as a token or refusing cooperation. Bureaucracy sometimes sucked us into Kafkaesque mazes, which afforded a glimpse of the everyday reality of many of our interviewees. However, we formed the impression, especially at the local level, that the voice of single 
teachers was not often heard and that they found a moment of empowerment in discussing the QAE steering tools which affected their everyday lives.

\section{Behind and beyond quality}

In relation to these dynamics, we believe we have made a convincing argument that the complexity of understanding the phenomena of politics of quality is embedded in the attempt to understand how it enables or hinders action. We started with the idea that politics is a means to control contingency. Where quality is concerned, QAE is a means to attempt to control what is done at different settings of action across all the contexts and institutions we have studied. We have elaborated this from the perspective of complexity, where it can be argued that attempts to control contingency increase the probability of action of one kind, while the probability of another decreases. Concretely, we argue in our research that the three dynamics described here are patterns which have become more probable in the politics of quality in education in Brazil, China, and Russia.

We recognise some limitations in our argument, however. Limited access to interviewees and observations and the issue of sensitivity in our data collection described in Chapter 2 have implications for the reliability and validity of the findings we report. Where reliability is concerned, we can first say that with better access to desired data in China and some of the potential key informants at the national level in Russia, we might have produced a more comprehensive and more nuanced picture of actor relations, data circulation, and the QAE enacted at the local level. At the same time, it is important to note that the concern here is not with the generalisability of our findings in the sense of their quantitative representativeness - even with more interviews and observations, our body of data in this sense would of course have remained very small. Instead, we emphasise that the value of our research's findings should be assessed by enquiring the extent to which we have contributed to a qualitative understanding of the issues we have analysed, for example, of the range of views expressed by interviewees rather than the perception of "the typical view" among different groups of actors or in each of the case countries.

With these reservations in mind, we certainly do not claim that our list of dynamics is exhaustive. As Chapter 2 discussed, there might be other possible interpretations of the research material we collected, because there might have been other foci. As this book concludes, we attempt to open some possible avenues for other interpretations, which may encourage further research on the politics of quality in education.

The notion that QAE has overtaken quality as a goal of education policy raises an interesting general question about how education is steered. There are many studies on the different techniques of governance, but this idea might be tested and developed by a deeper investigation of the comparison of policy and practice. This would especially require research on the use of knowledge in decision-making at different levels, possibly drawing on observation data, to 
enable an analysis of the extent to which QAE data are really used or to which they are a performance or fabrication. If data are not used, why gather them?

The way in which governance becomes more complex while authorising new actors to function in the political arena is interesting. We have clearly indicated the endless bureaucracy involved in QAE, but during this project's long journey, we have grown increasingly interested in the local level of action in the contexts we have studied. We continue the analysis based on our data and stress the importance in understanding thoroughly how local actor relations change.

The destabilising feature of QAE policies, which reorganises actor relations, is an interesting finding from the perspective of contingency. While quality policies are a means to control contingency, in other respects, contingency grows. This is a particularly interesting finding in the cases of Russia and China, where increasing contingency is not always considered politically desirable. Neither seems to conform to the argument of the state's diminishing role in the face of globalisation, which some of the researchers discussed in Chapter 1 expected.

The emphasis in the governance-at-a-distance literature has been predominantly a phenomenon of the Global North, with its theory having its roots in France and the UK. Our focus has been on large countries, two of which, China and Russia, are quite hierarchical, while the other, Brazil, is less top-down managed. None of the yielded results support the idea that the governance-at-a-distance theory is a good description of what we have observed. We do not claim to offer universal results with our data, but we believe it could well be opportune now for scholars outside these vast linguistic and territorial regions to take note of the serious doubt cast on this theoretical tradition.

\section{Bibliography}

Candido, D. H. H., Kauko, J., \& Centeno, G. V. (submitted). Portraying quality assurance and evaluation in Brazil: An analysis of how quality is problematized in Brazilian basic education.

Centeno, V. G., Kauko, J., \& Candido, H. H. (2017). Quality assurance and evaluation through Brazilian lenses: An exploration into the validity of umbrella concepts. Comparative Education 54(2), 132-158.

Dahler-Larsen, P. (2012). Constitutive effects as a social accomplishment: A qualitative study of the political in testing. Educational Inquiry, 3(2), 171-186.

Gurova, G. (2017). Soviet, post-Soviet and neoliberal: Governing Russian schools through quality assurance and evaluation. Policy Futures in Education.

Gurova, G., \& Piattoeva, N. (2019). A post-Soviet audit culture: Changing practices and subjectivities of school teachers in a Russian region. In L. M. Carvalho, L. Min, R. Normand, \& D. A. Oliveira (Eds.), Education Policies and the Restructuring of the Educational Profession. Global and Comparative Perspectives. Dordrecht: Springer.

Gurova, G., Piattoeva, N., \& Takala, T. (2015). Quality of education and its evaluation: An analysis of the Russian academic discussion. European Education, 47(4), 346-364. 
Kauko, J., Centeno, V. G., Candido, H., Shiroma, E., \& Klutas, A. (2016). The emergence of quality assessment in Brazilian basic education. European Educational Research Journal, 15(5), 558-579.

Minina, E., Piattoeva, N., Centeno, V. G., Zhou, X., \& Candido, H. H. (2018). Transnational policy borrowing and national interpretations of educational quality in Russia, China, and Brazil. In I. Silova \& M. Chankseliani (Eds.), Comparing Post-Socialist Transformations: Education in Eastern Europe and Former Soviet Union. Oxford: Symposium Books.

Piattoeva, N. (2018). Doing equality through greater transparency? Troubling surveillance expansion in the Russian school system. In S. Carney \& M. Schweisfurth (Eds.), Equity In and Through Education: Changing Contexts, Consequences, and Contestations. Rotterdam: Sense Publishers.

Piattoeva, N., \& Gurova, G. (2018). Domesticating international assessments in Russia: Historical grievances, national values, scientific rationality and education modernization. In C. Alarcon \& M. Lawn (Eds.), Assessment Cultures: Historical Perspectives (pp. 87-110). Frankfurt am Main: Peter Lang.

Piattoeva, N., \& Saari, A. (2018). The infrastructures of objectivity in standardized testing. In B. Maddox (Ed.), International Large-Scale Assessments in Education. New York, NY: Bloomsbury.

Simola, H., Kauko, J., Varjo, J., Kalalahti, M., \& Sahlström, F. (2017). Dynamics in Education Politics - Understanding and Explaining the Finnish Case. London: Routledge.

Suominen, O., Kallo, J., Rinne, R., \& Fan, Y. (2017). Subtle convergence? Locating similarities between Chinese educational reforms and global quality assurance and evaluation trends. Quality Assurance in Education, 25(2), 146-160.

Takala, T., Kauko, J., Rinne, R., \& Kallo, J. (2018). One size for all? - policy advice of the World Bank and the OECD on quality assurance and evaluation of school education in Russia, Brazil and China. In A. W. Wiseman \& P. M. Davidson (Eds.), Cross-Nationally Comparative, Evidence-Based Educational Policymaking and Reform. Bingley: Emerald. 
Appendix 1

Interview data and codes 


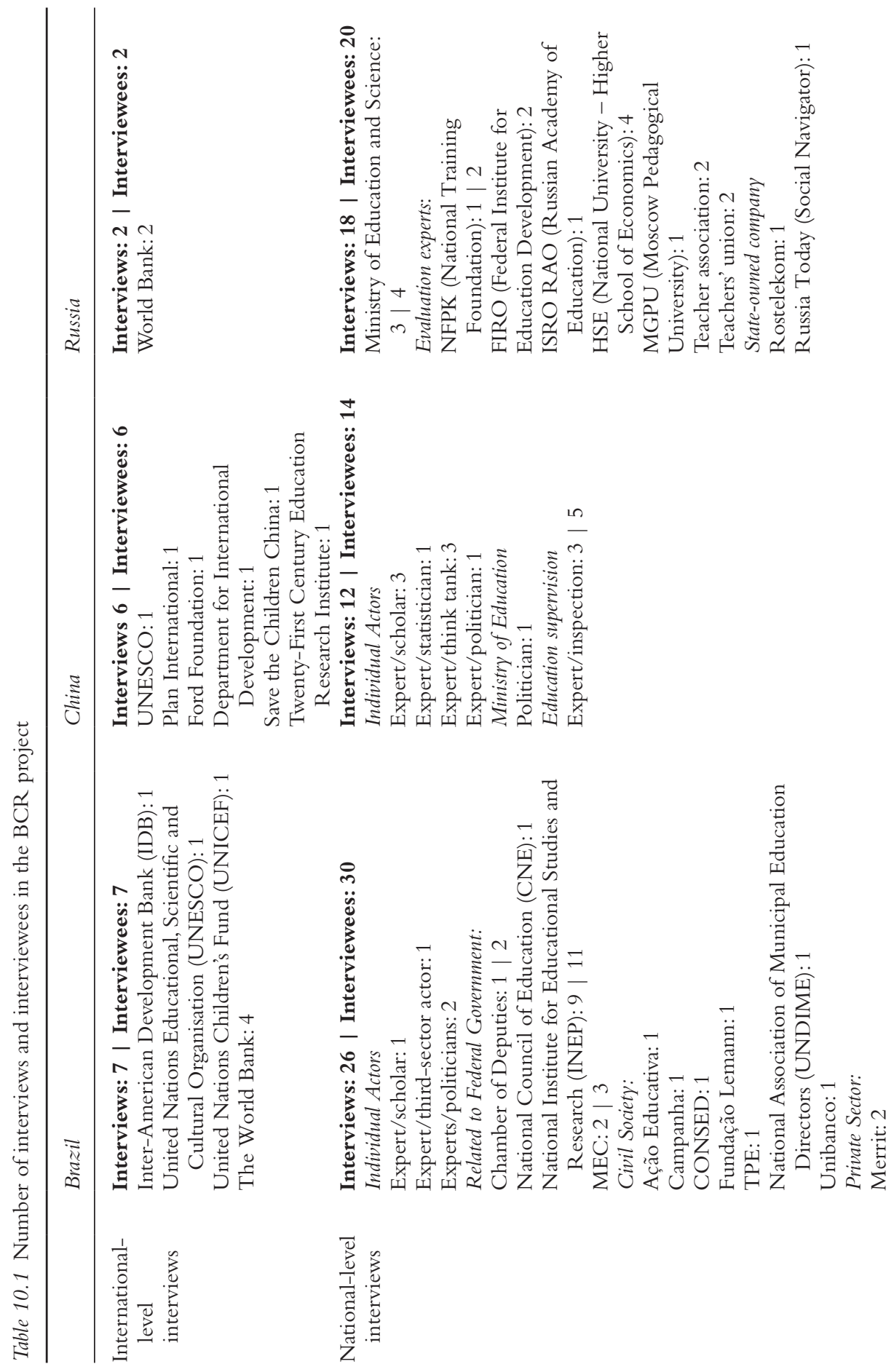



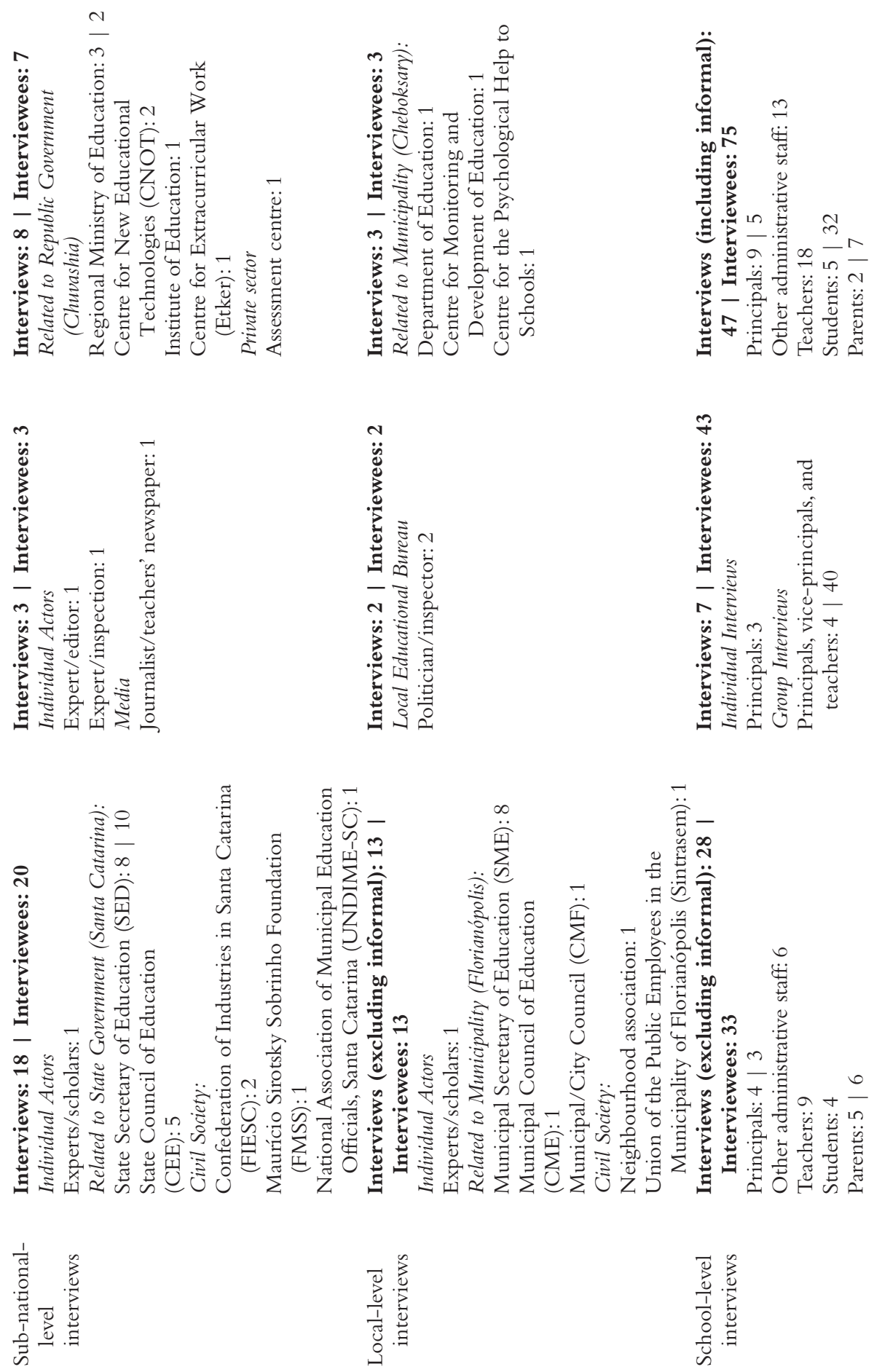


\section{Interview data and codes Appendix 1}

The interviews are coded according to the interviewees' positioning in the education arena at the time of the empirical work. However, most interviewees occupy or have occupied different positions throughout their careers, simultaneously or not. Their action benefits from the knowledge and the networks built within other scopes and scales of action. To ensure we preserve the interviewees' anonymity we will not share this detailed information.

People acting as politicians or civil servants at $\mathrm{N}=$ National level (federal or union)

$\mathrm{SN}=$ Sub-national level (region in

Russia, state in Brazil, province in China)

M = Municipal level (municipal government, city in China)

People acting as:

$\mathrm{E}=$ Expert (engaged as consultant, lecturer, and so on)

Events:

$\mathrm{SM}=$ Seminar
People acting in or for:

$\mathrm{IGO}=$ International governmental organisation

INGO = International non-governmental organisation

NNGO = National non-governmental organisation

SNGO = State non-governmental organisation

MNGO = Municipal non-governmental organisation

$\mathrm{PO}=$ Private organisation

$\mathrm{S}=$ School (teachers, principals, coordinators, psychologists, social pedagogues, students)

MS = Municipal school

MBS = Minban school (non-state operated school)

PS = Public school

$\mathrm{SS}=$ State school

$\mathrm{MD}=$ Media 


\section{Appendix 2}

\section{Coding of interviews}

\section{Analysis tools}

To ensure a valid and equivalent analysis of the interview material, the Chinese team at the University of Turku used NVIVO 11, whereas the Brazilian and Russian teams at the University of Tampere used ATLAS.TI 7. While both were equally adequate for the analysis we needed, the final choice depended on practical considerations, such as the availability of the programme licence and the home institution. Since both programmes allow input in multiple languages and the researchers working with the coding were fluent in both languages, we did not translate the material from Chinese, Russian, and Portuguese into English but simply did the coding in English. Translations were later done for the coding units used as citations in the chapters.

Coding units (ATLAS.TI: quotations, NVIVO: references) refer to the block of material selected for coding. The rule for delimiting the coding unit was the topic/issue captured within a piece of text, rather than the physical linguistic units (e.g., word, sentence, or paragraph). To make them fully understandable, selected coding units included necessary contextualisation information (material before and after). Sometimes this required enclosure of the interviewer's questions or large sections of the text in which the interviewee digressed but then returned to the topic, because if this were considered as two quotations instead of one, the second would make no sense.

It must also be noted that coding units were not mutually exclusive, and the same coding unit might belong to more than one category. For example, in the Chinese case, interviewees frequently mentioned the challenges for education and the existing unequal situations in Chinese basic education together. Therefore, these coding units were coded under the categories of "challenges" and "inequality", as they revealed relevant information about both topics.

The interviews were exhaustively coded. The exhaustiveness of coding implied that even when the issue was not directly connected with the main research question (e.g., about childhood education), this part of the text was nevertheless coded.

The category definition (ATLAS.TI: codes/sub-codes; NVIVO: notes/ sub-notes) includes the category name (ATLAS.TI: code name; NVIVO: 
name) and its description (ATLAS.TI: comment; NVIVO: description). The latter includes what is meant by that sub-category or category, which features are included, the criteria or decision rules, and other relevant information for understanding the coding's structure. In brief, categories' names and descriptions make a coding frame which allows the coder to code the material and "outsiders" to make sense of the coding.

The main categories refer to what the researcher wishes to know within the research, whereas sub-categories normally denote the substance of the main codes. They are therefore frequently data driven. Categories or sub-categories describe the selected coding units (Qualitative Content Analysis: coding frame, coding manual, or code book; ATLAS.TI: coding list; NVIVO: node list). Whereas the same coding unit may belong to more than one category, the main categories should cover only one aspect or theme of the material, and sub-codes within a given code should be mutually exclusive: there cannot be two or more referring to the same topic within that main category.

For example, in the coding of the Brazilian interviews, we had the following coding unit: "The IDEB [Development Index of Basic Education], it works with targets, it is in that framework of the PDE [Education Development Plan] of 2017, and there was an effort of the Government in finding some type of meeting point between the scale of Programme for International Student Assessment (PISA) and the scale of the SAEB [Evaluation System of Basic Education on which the IDEB is based]." Although this segment of text could have been cut into smaller coding units, we chose to keep it in its entirety to preserve its full meaning and context. However, since it covered several relevant issues, we coded it with six different sub-categories belonging to four categories, namely: "Quality evaluation: national instruments: IDEB”; "Quality evaluation: national instruments: SAEB"; "Quality evaluation: international instruments: PISA”; “Quality evaluation/improvement: paths of influence”; "Quality improvement: Federal Government Programme: PDE"; and "Actors: relations: INEP-Federal Government". The first category, "quality evaluation", is divided into several sub-categories, among which some refer to the national and international instruments used to assess quality. In turn, to analyse the material as accurately as possible, we have created sub-sub-categories with the names of the instruments mentioned (IDEB, PISA, and SAEB). It is also clear in this segment of text that visions about how quality evaluation might be improved (category "quality evaluation/improvement") were influenced by concrete developments, practices, or policies. This was frequently detected and coded under the sub-category "paths of influence". In this case, the influence was clearly PISA. This sub-category could indeed have been further divided, for example, by describing the exact influences, as was previously done for "inter/national instruments". However, since the number of coding units was much smaller and simultaneously more homogeneous (most mentions referred to the same influences), this would have led to some imbalanced sub-categories, as some would have one or two coding units, while others would gather almost all the coding units of that sub-category. We therefore decided to keep them all in one 
sub-category. This coding unit also refers to two other topics. One was a federal programme which was perceived as a tool for quality improvement, and which was in turn connected with national and international instruments of quality evaluation. This was thus of major relevance. It was then coded under a subcategory which referred to federal programmes formulated to improve education quality. The programme itself provided the name of the sub-subcategory according to the logic described for instruments. Another topic implicit in this coding unit was the relationship between the agency in charge of the assessments, the INEP (National Institute for Educational Studies and Research) and the government. The INEP designed the SAEB and IDEB, but the effort of making them compatible with PISA was not only technical for the INEP, but also a clear political effort from the government. This reveals something about the relationship between the INEP and the government, and it is therefore also coded under the sub-category referring to relationships between actors, particularly the relationship between the INEP and the federal government.

\section{Validity and coordination within and between teams}

Using the interview guidelines (Appendix 3), we discussed the initial set of categories, which mainly covered areas that we wanted to explore further, and this initial coding frame was shared between all three teams but subsequently adjusted to fit each country case. All teams had several persons engaged in coding, allowing crosschecking at different stages of the process. The coding frame was constantly refined and updated during the coding process. At the end of each working package, researchers usually revised and expanded the categories. In brief, within each team, all involved in coding discussed changes in the coding frame. The categories were not readapted or forced on new pieces of data. Instead, if categories did not completely match data, the differences or particularities were reported in the category's description, or a new sub-category was created to fit the material.

For example, in the Russian case, this refinement process led to the creation of new sub-categories at the end of the coding process. There were thus several sub-categories which emerged as a result of later analysis of the whole body of data. A concrete example is the sub-category "visibility", which signifies cases when data collections were justified by respondents to demonstrate (to the public and officials) evidence of good or bad performance, locating certain problems, and so on. We saw the relevance of this sub-category only when we had reviewed the whole coding. The frequent revision of the coding frame and the exchange between researchers were fundamental to the coding of interviews. 


\section{Appendix 3}

\section{Interview guidelines}

\section{Main idea}

The main idea behind this guideline is to set out common core questions essential for the goals of each of the four main themes. The main goals of each theme and the core questions offer a basis for balancing the questionnaire and adjusting it to country-specific needs.

\section{Methodological notes}

Prior to the interview, the interviewer should have a good understanding of the role of that organisation (school, government, international organisation, nongovernmental organisation, and so on), based on documents and a literature review. Depending on the time frame and nature of the interview, it is also possible for the interviewer to allow the interviewee briefly to present himself or herself to gain an understanding of his or her position in the organisation and his or her role in QAE (Quality Assurance and Evaluation) dynamics, as well as the organisation's position and role in such dynamics.

\section{Terminology}

$\mathrm{CC}=$ common core question, a question presented in all three BCR (Brazil, China, and Russia) cases

$\mathrm{CFU}=$ common follow-up question, a question presented in all three BCR cases, however adapted or omitted, depending on the answer given to CC

LS = level-specific question, a question to be asked only on a specific level (transnational, international, federal, national, state, regional, local, school)

AS = actor-specific question, a question to be asked only of a specific actor group (for example, teacher or politician)

IOs = international organisations (governmental and non-governmental, i.e., IGOs and INGOs)

$\mathrm{LO}=$ local organisations (e.g., NGOs)

Actor $=$ adjust terminology according to the person being interviewed (i.e., refer to organisations, people, or actors generally) 


\section{Theme 1: Introduction}

First goal of the theme: to understand the respondent's view on quality and evaluation in basic education.

\begin{tabular}{|c|c|c|c|}
\hline & Priority & Questions & Notes \\
\hline 1 & $\mathrm{CC}$ & $\begin{array}{l}\text { How do you understand } \\
\text { "quality in basic education"? }\end{array}$ & \\
\hline 1.1 & CFU & $\begin{array}{l}\text { Should quality be assessed? } \\
\text { Why? }\end{array}$ & $\begin{array}{l}\text { Order of questions } 1.2 \text { and } 1.3 \text { can be } \\
\text { changed - adjust according to the answers. }\end{array}$ \\
\hline 1.2 & CFU & $\begin{array}{l}\text { How is quality assessed in } \\
\text { Brazilian/Chinese/Russian } \\
\text { basic education? Is there } \\
\text { a national/regional/local } \\
\text { quality/evaluation system? } \\
\text { Please give concrete } \\
\text { examples. }\end{array}$ & $\begin{array}{l}\text { Direct connection may be made with } \\
\text { testing regimes when appropriate; decide } \\
\text { according to answers. } \\
\text { Questions about quality and/or assessment } \\
\text { practices and policies' implementation may } \\
\text { be asked. Adjust accordingly: Which actors } \\
\text { have participated in the process? What } \\
\text { were their roles in the process? Who has } \\
\text { provided support/expertise/funding? } \\
\text { If more than one quality/evaluation system is } \\
\text { mentioned, it may be asked why they were } \\
\text { implemented if there were already other } \\
\text { main quality and/or assessment practices } \\
\text { and policies. } \\
\text { Questions may be asked about how the main } \\
\text { (and other) quality and/or assessment } \\
\text { practice and policy have been received by } \\
\text { public opinion and other stakeholders. }\end{array}$ \\
\hline 1.3 & LS/AS & $\begin{array}{l}\text { Is there a difference between } \\
\text { "quality of education" and } \\
\text { an "education of quality"? }\end{array}$ & $\begin{array}{l}\text { May be more relevant to Brazilian and } \\
\text { Chinese cases. Adjust according to answer } \\
\text { to question 1. } \\
\text { The idea is to understand and explore the } \\
\text { eventual differences - if any - between } \\
\text { "Quality of Education"/"Education } \\
\text { Quality" and "Education of Quality"/ } \\
\text { "Quality Education"/"Education Quality". }\end{array}$ \\
\hline 2 & $\mathrm{CC}$ & $\begin{array}{l}\text { How do you understand } \\
\text { "evaluation"? }\end{array}$ & $\begin{array}{l}\text { Adjust according to answers to question } \\
1 \text {, perhaps as a follow-up question, but } \\
\text { this may be unnecessary because the } \\
\text { interviewee's answer included it already. }\end{array}$ \\
\hline 2.1 & CFU & $\begin{array}{l}\text { How do you see the } \\
\text { relationship between } \\
\text { "quality" and "evaluation"? }\end{array}$ & As above. \\
\hline 3 & $\mathrm{CC}$ & $\begin{array}{l}\text { From your perspective, what } \\
\text { are the most important } \\
\text { problems and challenges in } \\
\text { Brazilian/Chinese/Russian } \\
\text { basic education? Why? }\end{array}$ & $\begin{array}{l}\text { Adjust according to the country in question. } \\
\text { For IOs/Los, perhaps omit country or } \\
\text { understand if they are talking about their } \\
\text { particular country or in general (to make } \\
\text { an explicit differentiation). }\end{array}$ \\
\hline
\end{tabular}




\begin{tabular}{|c|c|c|c|}
\hline & Priority & Questions & Notes \\
\hline 3.1 & $\mathrm{CFU}$ & $\begin{array}{l}\text { Are there differences in } \\
\text { opinion between the various } \\
\text { actors involved? }\end{array}$ & $\begin{array}{l}\text { Adjust according to answer to question } 3 \text {. } \\
\text { This may have already been mentioned. } \\
\text { Please note this answer may be more } \\
\text { related to the following theme (actors), } \\
\text { depending on the detail into which the } \\
\text { interviewee goes at this point. }\end{array}$ \\
\hline 3.2 & $\mathrm{CFU}$ & $\begin{array}{l}\text { Have the problems/challenges/ } \\
\text { opinions changed recently? } \\
\text { When? }\end{array}$ & $\begin{array}{l}\text { Adjust according to answer to questions } 3 \\
\text { and 3.2. This may have been mentioned } \\
\text { already. Please note that this answer may be } \\
\text { more related to dynamics, depending on } \\
\text { the detail into which the interviewee goes } \\
\text { at this point. }\end{array}$ \\
\hline
\end{tabular}

Second goal of the theme: to understand the interviewee's concrete involvement in - and its perceived impact on - QAE policy and practice. (Only used if it is impossible to gain information beforehand.)

\begin{tabular}{|c|c|c|c|}
\hline & Priority & Questions & Notes \\
\hline 3.3 & CFU & $\begin{array}{l}\text { How did you come to work } \\
\text { with basic education/ } \\
\text { evaluation/quality? }\end{array}$ & $\begin{array}{l}\text { This serves as the main question for the } \\
\text { second goal of theme } 1 \text { but is optional. }\end{array}$ \\
\hline 3.4 & LS/AS & $\begin{array}{l}\text { What is your role/the role } \\
\text { of your organisation/unit/ } \\
\text { department? }\end{array}$ & $\begin{array}{l}\text { Adjust according to interviewee and previous } \\
\text { answers. }\end{array}$ \\
\hline 3.5 & LS/AS & $\begin{array}{l}\text { Do you (or your organisation) } \\
\text { produce or use any data } \\
\text { related to quality and } \\
\text { evaluation in education? }\end{array}$ & As above. \\
\hline 3.6 & LS/AS & $\begin{array}{l}\text { Are you indirectly/ } \\
\text { directly involved in } \\
\text { national/regional/local } \\
\text { policymaking? }\end{array}$ & $\begin{array}{l}\text { As above. Main idea: to understand if } \\
\text { they have - or perceive that they } \\
\text { have - an impact and, if so, what kind } \\
\text { (e.g., discursive, pragmatic)? }\end{array}$ \\
\hline 3.7 & LS/AS & $\begin{array}{l}\text { What is your role/the role } \\
\text { of your organisation/unit/ } \\
\text { department in seeking } \\
\text { to address the problems } \\
\text { [mentioned in question 3]? }\end{array}$ & $\begin{array}{l}\text { Adjust according to interviewee and to } \\
\text { answers to question } 1.3 / 2.3 \text { and } 3 / 3.1 \text {. }\end{array}$ \\
\hline 3.8 & LS/AS & $\begin{array}{l}\text { What are the main challenges } \\
\text { in your own work/action? }\end{array}$ & Adjust according to actor and level. \\
\hline
\end{tabular}

\section{Theme 2: Actors}

First goal of the theme: to identify the main actors (collective or individual) in the field and their role/action and perceived impact in quality and evaluation policy and practice. (The first goal concerns only macro- and meso-level actors.) 


\begin{tabular}{|c|c|c|c|}
\hline & Priority & Questions & Notes \\
\hline 4 & $\mathrm{CC}$ & $\begin{array}{l}\text { Which actors would } \\
\text { you consider the most } \\
\text { important in shaping basic } \\
\text { education policy? Please } \\
\text { describe who they are. }\end{array}$ & $\begin{array}{l}\text { Adjust question concerning the level (human } \\
\text { or organisation actors; education field or } \\
\text { community; passive or active approaches; } \\
\text { and so on. Perhaps use the language of the } \\
\text { interviewee so terminology is not an obstacle). }\end{array}$ \\
\hline 4.1 & CFU & $\begin{array}{l}\text { Does their importance vary } \\
\text { according to policy issue? }\end{array}$ & $\begin{array}{l}\text { Order of questions } 4.1,4.2 \text {, and } 4.3 \text { may be } \\
\text { changed - adjust according to the answer. }\end{array}$ \\
\hline 4.2 & CFU & $\begin{array}{l}\text { How do these actors deal } \\
\text { with the problems you } \\
\text { identified previously [in } \\
\text { answers to questions in } \\
\text { Theme } 1 \text { and to } 4.1 \text { ]? }\end{array}$ & Adjust accordingly. \\
\hline 4.3 & CFU & $\begin{array}{l}\text { What has been the role of } \\
\text { standardised testing in } \\
\text { this context? In which } \\
\text { measure and by whom? }\end{array}$ & $\begin{array}{l}\text { Perhaps already answered. Adjust accordingly. } \\
\text { Main idea: to understand if the performance } \\
\text { evaluation/indicators/rankings and so on } \\
\text { are part of the solution and how, why, and } \\
\text { by whom (in the eyes of the interviewee). }\end{array}$ \\
\hline 4.4 & LS/AS & $\begin{array}{l}\text { What sources of } \\
\text { information do they use } \\
\text { for evaluating quality [in } \\
\text { answer to question } 4.3 \text {. } \\
\text { or previously]? }\end{array}$ & Adjust according to level and actor. \\
\hline 4.5 & LS/AS & $\begin{array}{l}\text { Are these data reliable? } \\
\text { Please explain. }\end{array}$ & Adjust according to level and actor. \\
\hline 4.6 & LS/AS & $\begin{array}{l}\text { Who uses this information } \\
\text { and for what? Please give } \\
\text { examples. }\end{array}$ & Adjust according to level and actor. \\
\hline 4.7 & $\begin{array}{l}\text { Optional: } \\
\text { CFU } \\
\text { LS/AS }\end{array}$ & $\begin{array}{l}\text { Are international organisations } \\
\text { or experts involved in the } \\
\text { practices you mentioned [in } \\
\text { 4.2. and 4.3]? }\end{array}$ & $\begin{array}{l}\text { Adjust according to previous answers and level/ } \\
\text { actor. Perhaps already mentioned. Main idea: } \\
\text { to understand the role of international experts } \\
\text { and/or organisations. }\end{array}$ \\
\hline
\end{tabular}

Second goal of the theme: to understand the position of the interviewed actor in the field, as well as the connections/relations between different actors.

\begin{tabular}{|c|c|c|c|}
\hline & Priority & Questions & Notes \\
\hline 5 & $\mathrm{CC}$ & $\begin{array}{l}\text { Who are your main partners in } \\
\text { dealing with basic education? }\end{array}$ & $\begin{array}{l}\text { Adjust accordingly: basic } \\
\text { education policy/local } \\
\text { community/and so on. }\end{array}$ \\
\hline 5.1 & $\begin{array}{l}\text { CFU, } \\
\text { LS/AS }\end{array}$ & $\begin{array}{l}\text { With which other actors do you } \\
\text { (and/or your organisation) interact } \\
\text { regarding basic education issues? }\end{array}$ & \\
\hline 5.2 & CFU & $\begin{array}{l}\text { In which projects/programmes do } \\
\text { you cooperate and how? Please give } \\
\text { examples. }\end{array}$ & \\
\hline
\end{tabular}




\begin{tabular}{|c|c|c|c|}
\hline & Priority & Questions & Notes \\
\hline 5.3 & CFU & $\begin{array}{l}\text { Why are you not working with all the } \\
\text { actors [in answer to question 4]? }\end{array}$ & $\begin{array}{l}\text { Main idea: to investigate if } \\
\text { there are any reasons for not } \\
\text { working with some of the } \\
\text { actors mentioned above. }\end{array}$ \\
\hline 5.4 & $\begin{array}{l}\text { CFU, } \\
\text { LS/AS }\end{array}$ & $\begin{array}{l}\text { Are you/your organisation/ } \\
\text { department involved in quality } \\
\text { and/or evaluation practices in } \\
\text { [Brazil/China/Russia OR in this } \\
\text { region/state/municipality]? }\end{array}$ & $\begin{array}{l}\text { Adjust accordingly. Perhaps } \\
\text { redundant, depending } \\
\text { on the previous answers } \\
\text { (especially to 3.4). }\end{array}$ \\
\hline 5.5 & LS/AS & $\begin{array}{l}\text { Are you personally involved in these } \\
\text { developments? In what capacity } \\
\text { and since when? For how long have } \\
\text { you been (and will you be staying?) } \\
\text { in this position? Where and what } \\
\text { was your previous position? }\end{array}$ & $\begin{array}{l}\text { Several follow-up questions } \\
\text { possible, adjust to level/ } \\
\text { actor and previous answers. }\end{array}$ \\
\hline 5.6 & CFU & $\begin{array}{l}\text { Can you establish a time line } \\
\text { regarding the roles of the actors [in } \\
\text { answers to questions to Theme 2]? } \\
\text { Have their roles changed? How } \\
\text { and why? }\end{array}$ & $\begin{array}{l}\text { Possibly serves as a bridge to } \\
\text { the following theme. Adjust } \\
\text { accordingly. }\end{array}$ \\
\hline
\end{tabular}

\section{Theme 3: Change dynamics}

First goal of the theme: to understand changes in actor relations.

\begin{tabular}{|c|c|c|c|}
\hline & Priority & Questions & Notes \\
\hline 6 & $\mathrm{CC}$ & $\begin{array}{l}\text { Why did you start working } \\
\text { with the partners you } \\
\text { mentioned previously [in } \\
\text { question 5]? Why then? }\end{array}$ & $\begin{array}{l}\text { The question may be asked negatively: } \\
\text { why have you never worked with these } \\
\text { actors [not mentioned in question } \\
\text { 5; name actors unmentioned by the } \\
\text { interviewee or those unmentioned } \\
\text { as partners]? OR Why have you } \\
\text { discontinued working with the partners } \\
\text { you mentioned before [in question 5]? }\end{array}$ \\
\hline 6.1 & CFU & $\begin{array}{l}\text { How would you describe } \\
\text { your relationship with } \\
\text { the partners with whom } \\
\text { you work [mentioned in } \\
\text { questions } 5 \text { and 6]? }\end{array}$ & $\begin{array}{l}\text { Perhaps answered before. Adjust } \\
\text { accordingly: competitive, cooperative, } \\
\text { coalitional, conflicting, and so on/ } \\
\text { voluntary, mandatory, negotiated, and } \\
\text { so on. }\end{array}$ \\
\hline 6.2 & $\begin{array}{l}\text { CFU, } \\
\text { LS/AS }\end{array}$ & $\begin{array}{l}\text { How would you describe } \\
\text { the relationships between } \\
\text { partners in the field } \\
\text { of basic education in } \\
\text { general? }\end{array}$ & Adjust according to level and actor. \\
\hline
\end{tabular}


Second goal of the theme: to understand the role "quality" and "evaluation" practice and policy have played in the changes of the first goal of this theme and to identify whether and how they define relations among and between actors (or vice versa).

\begin{tabular}{|c|c|c|c|}
\hline & Priority & Questions & Notes \\
\hline 8 & $\mathrm{CC}$ & $\begin{array}{l}\text { How does your work with these } \\
\text { actors [mentioned in question } \\
\text { 6] help to tackle the problems } \\
\text { in basic education mentioned } \\
\text { earlier [in Theme 1]? }\end{array}$ & $\begin{array}{l}\text { May be asked in the previous } \\
\text { theme [question 5]. Depending } \\
\text { on answer, may also be asked } \\
\text { negatively: how do relations } \\
\text { among actors impede the } \\
\text { tackling of problems? }\end{array}$ \\
\hline 8.1 & $\begin{array}{l}\text { CFU, } \\
\text { LS/AS }\end{array}$ & $\begin{array}{l}\text { In what respect are these relations } \\
\text { consensual? Are there differences } \\
\text { in opinions/practices/goals } \\
\text { between different actors in } \\
\text { tackling the problems in basic } \\
\text { education mentioned earlier [in } \\
\text { Theme 1]? Why? }\end{array}$ & $\begin{array}{l}\text { Perhaps already answered. Adjust } \\
\text { accordingly. }\end{array}$ \\
\hline 9 & $\mathrm{CC}$ & $\begin{array}{l}\text { Have there been changes in } \\
\text { dealing with basic education } \\
\text { problems? Why? }\end{array}$ & $\begin{array}{l}\text { Adjust accordingly for content, } \\
\text { division of labour between } \\
\text { actors, share of responsibilities } \\
\text { between different levels, and } \\
\text { so on. } \\
\text { Depending on answer, may also be } \\
\text { asked negatively: why didn't this } \\
\text { change? }\end{array}$ \\
\hline 9.1 & $\mathrm{CFU}$ & $\begin{array}{l}\text { Who pushes for changes? What } \\
\text { are the main reasons? Who } \\
\text { resists these changes? Why? }\end{array}$ & \\
\hline 9.2 & $\mathrm{CFU}$ & $\begin{array}{l}\text { What has initiated or been the } \\
\text { reason for these changes? }\end{array}$ & $\begin{array}{l}\text { Perhaps already answered. Adjust } \\
\text { accordingly. }\end{array}$ \\
\hline 9.3 & $\mathrm{CFU}$ & $\begin{array}{l}\text { Which actors were behind these } \\
\text { changes? }\end{array}$ & $\begin{array}{l}\text { Perhaps already answered. Adjust } \\
\text { accordingly. }\end{array}$ \\
\hline 9.4 & $\begin{array}{l}\text { CFU, } \\
\text { LS/AS }\end{array}$ & $\begin{array}{l}\text { Do you think that the (recent?) } \\
\text { developments in quality and } \\
\text { evaluation are involved in these } \\
\text { changes? In which measure? } \\
\text { Please explain. }\end{array}$ & $\begin{array}{l}\text { Perhaps already answered. Adjust } \\
\text { according to previous answers, } \\
\text { level, and actor. }\end{array}$ \\
\hline 9.5 & $\begin{array}{l}\text { CFU, } \\
\text { LS/AS }\end{array}$ & $\begin{array}{l}\text { Are these changes peculiar to } \\
\text { Brazilian/Chinese/Russian } \\
\text { OR to this state's/region's/ } \\
\text { municipality's education? }\end{array}$ & $\begin{array}{l}\text { Adjust accordingly. Main idea of } \\
\text { this question: to understand the } \\
\text { horizon of interpretation. }\end{array}$ \\
\hline 9.6 & $\mathrm{CFU}$ & $\begin{array}{l}\text { What are the benefits/negative } \\
\text { effects of these changes? How } \\
\text { well do you think Brazil/ } \\
\text { China/Russia has accepted such } \\
\text { changes and adapted to them? }\end{array}$ & $\begin{array}{l}\text { Perhaps already answered. Adjust } \\
\text { accordingly. }\end{array}$ \\
\hline & $\ldots$ & & \\
\hline
\end{tabular}


Third goal of the theme: to understand transnational connections and their impact on national and sub-national policy and practice.

\begin{tabular}{|c|c|c|c|}
\hline & Priority & Question & Notes \\
\hline 10 & $\begin{array}{l}\text { CC, } \\
\text { LS/AS }\end{array}$ & $\begin{array}{l}\text { Have Brazilian/Chinese/Russian } \\
\text { policymakers/teachers/and so on used the } \\
\text { experience of policy/practice from other } \\
\text { local/regional/national/international } \\
\text { actors? From where, why, and how have } \\
\text { they used such experience? }\end{array}$ & $\begin{array}{l}\text { Questions may be asked } \\
\text { about particular } \\
\text { programmes, actors, or } \\
\text { policies. }\end{array}$ \\
\hline 11 & $\mathrm{CC}$ & $\begin{array}{l}\text { Do you think that Brazilian/Chinese/ } \\
\text { Russian developments in evaluation } \\
\text { and/or quality practice and policy have } \\
\text { inspired (or been used by) others locally/ } \\
\text { regionally/nationally/internationally? } \\
\text { Which, how, and why? }\end{array}$ & $\begin{array}{l}\text { Questions may be asked } \\
\text { about particular } \\
\text { programmes, actors, or } \\
\text { policies according to } \\
\text { context. }\end{array}$ \\
\hline
\end{tabular}

\section{Theme 4: Future}

Main goal of the theme: to understand the actors' expectations and the possibilities they perceive.

\begin{tabular}{|c|c|c|c|}
\hline & Priority & Question & Notes \\
\hline 12 & $\mathrm{CC}$ & $\begin{array}{l}\text { How do you see the future trajectories in } \\
\text { basic education in the short and long term? }\end{array}$ & \\
\hline 12.1 & CFU & $\begin{array}{l}\text { Are these related to quality and evaluation in } \\
\text { education? }\end{array}$ & $\begin{array}{l}\text { Perhaps already } \\
\text { answered before. } \\
\text { Adjust accordingly. }\end{array}$ \\
\hline 12.2 & LS/AS & $\begin{array}{l}\text { Which actors do you think will be involved in } \\
\text { the trajectories? How and why? }\end{array}$ & \\
\hline \multirow[t]{2}{*}{12.3} & LS/AS & $\begin{array}{l}\text { How do you see your work/institution's } \\
\text { activities involved in these developments? }\end{array}$ & \\
\hline & $\ldots$ & & $\begin{array}{l}\text { Questions may be asked } \\
\text { about particular } \\
\text { developments. }\end{array}$ \\
\hline 13 & $\mathrm{CC}$ & $\begin{array}{l}\text { In an ideal world, what would be the perfect } \\
\text { trajectory [considering what was mentioned } \\
\text { in answer to question 3]? }\end{array}$ & \\
\hline 13.1 & $\mathrm{CFU}$ & $\begin{array}{l}\text { What changes do you consider necessary } \\
\text { in basic education? Would you change } \\
\text { anything related to evaluation and/or } \\
\text { quality policy and practice? }\end{array}$ & $\begin{array}{l}\text { Adjust according to } \\
\text { interactions, data, } \\
\text { actors, and so on. }\end{array}$ \\
\hline \multirow[t]{2}{*}{13.2} & CFU & $\begin{array}{l}\text { How would your work (institution) } \\
\text { contribute to this perfect trajectory? }\end{array}$ & \\
\hline & $\cdots$ & & $\begin{array}{l}\text { Questions may be asked } \\
\text { about particular } \\
\text { developments. }\end{array}$ \\
\hline
\end{tabular}




\section{Index}

Page numbers in italics indicate figures and in bold indicate tables.

abductive research design 19

academic research in China 102-105

accountability of authorities 150-151

action see room for action; use of political space in CADEP framework actors: in Brazil 80-82; in China 82-84;

destabilising and reorganised roles of 186-188; in education 1 ; in governance at a distance 117 ; interactions with agendas 71-73, 79-87; in Russia 84-87; schools as 140-141; states as 7; transnational expert communities as 87-88; in transnational network 5-6; trust and mistrust between 132-133; see also expertise/experts; political situation in CADEP framework

agendas: as changing, in 1990s $73-75$;

interactions with actors $71-73,79-87$; of international organisations $182-184$ archetypal images of future 163-164, 175-176

assessment system: in China $54-56,77-78$, 82 ; in Russia $56-57,85$

audit society $94-95$

borrowing and lending theories 4

Brazil: archetypal images of future in 175 ; building capacity in $75-77$; civic movements in 80-82; data circulation in 118-119; data collection in 27-28; historical trajectories and pushes of present in 164-166; path towards QAE in $45-51,61$; perceptions of future in 166-168; political instability in 33-34; rise of school performance evaluation in 142-143; Santa Catarina 141; school visits in 38; state and expertise in 99-101; see also Evaluation System of Basic Education

BRICS 7-8, 63-64; see also Brazil; China; Russia

bureaucratic-professional model of governance 138

CADEP framework see Comparative Analytics of Dynamics in Education Politics (CADEP) framework

case countries 7-9; see also Brazil; China; Russia

centralisation of education in Russia 56-57, 60

Cheboksary, Russia 141-142

China: actors in $82-84$; archetypal images of future in 175 ; building capacity in 77-78; data circulation in 119; data collection in 28-29; engagement with international community $73-74$; historical trajectories and pushes of present in 168-169; official approval in 34; path towards QAE in 51-56, 61; perceptions of future in 169-171; rise of school performance evaluation in 143-144; school visits in 38-39; state and expertise in 101-105; see also National Assessment of Education Quality

"China Dream" 169

circulation of data: in Brazil, China, and Russia 118-121; data availability and 123-127; data production and 121-123; data use and 127-131; governance at a distance through 116-118, 131-133 civic movements in Brazil 80-82 
Comparative Analytics of Dynamics in Education Politics (CADEP) framework: conduct of research within 39-41; dimensions of 9,21, 40; overview 8, 21; paradox in 181; political possibilities in 22-23; political situation in 21-22; project consortium and work mode 11-12; reflective approach of 18-19; systematics of research procedure $25-32$, 26; use of political space in 23-25; see also dynamics in politics of quality comparative education and policy transfer 4-5

comparing dynamics method/perspective 19-21

complexity theory $3,9,161,181$

contingency 3,45

critical futures studies 161

data and data systems: in Brazil 100-101; in case countries 110-111; in China 102-105; expertise and 97-98; in governance at a distance 115-118, 131-133; in Russia 106-109; see also circulation of data

data collection: for project 27-31, 141-142; reliability of 132; in Russia 85-86; by states 92

decentralisation of education: in Brazil 45-46, 49-50, 118; in China 51-52, 55; in Russia 58

destatization 97

discourse see political possibilities in CADEP framework

dualism in domestic policy in Russia 172-173

dynamics in education: in case countries 7-8; research focus on 19-21

dynamics in politics of quality: authorising but diverted governance 181,184-186; destabilising and reorganised rolesetting 181-182, 186-188; overview 11, 181-182, 182; shared and self-reinforcing goal setting 181, 182-184

economic growth and learning achievement 6,59

education governance by data $115-116$ evaluation: defined 1 ; as internal management tool for schools 152-153; of local authorities 150-151; of schools, as indirect intervention 145-147; of schools, reliability of results of 156 ; see also quality assurance and evaluation
Evaluation System of Basic Education (SAEB, Brazil): data availability and 126; data circulation and 118-119; data production and $122-123$; data use and $127-128$; overview 33, 49, 50, 116, 142-143

expert community: influence of, in 1990s 73 ; membership in 80; room for action of 185; state and 109-110; as transnational $87-88$

expertise/experts: capacity of anticipation and 91-92; context of 97-99; in production and interpretation of knowledge 91; roles of and relationship between state and 92-93, 109-111; state and, in Brazil 99-101; state and, in China 101-105; state and, in Russia 105-109; see also expert community

fieldwork: coping with politics and bureaucracy 33-36; manifestations of hierarchies and effects of QAE 36-39; self-reflection on 32-33

framework, defined 8

friction in data circulation 133

future of QAE: concepts of time and archetypes of 162-164; overview 161-162, 174-176; perceptions of, in Brazil 164-168; perceptions of, in China 168-171; perceptions of, in Russia $171-174$

futures triangle 163-164

garbage can model 23-24

global education industry 96

global inspectorate or audit society 94-95

globalism, as archetype of future 164

governance: as authorising but diverted 181, 184-186, 189; in China 55; as continuum 95; data as currency of 98; at a distance 115-118, 131-133, 139-140, 185-186; local, QAE in 138-140, 145-151, 157-158; national education systems and 95-97; networked 98; QAE as tool of 2; use of term 93-94

governance technology 94

historical paths towards quality assurance and evaluation (QAE): in Brazil 45-51, 61; in China 51-56, 61; commonalities and differences in 61-63; in Russia 56-60, 62

historical trajectories: in Brazil 164-166; in China 168-169; in futures research 163; in Russia 171-173 
"improvement through evaluation" discourse 145-147

Index for Development in Basic Education (IDEB, Brazil) 99, 142-143, 166

INEP (National Institute for Educational Studies and Research, Brazil) 99-101, 118-119, 123, 126

influence of schools 154-155

INGOs in China 77, 78, 82-83

inspections of schools, reward and punishment based on 147-150 intended political project of data 115 , 131-133

international, defined 2

international influence and cooperation 62 , $63-64,72$

international organisations (IGOs): agendas of 182-184; cooperation with, and building capacity $75-79$; engagement with $73-75,79$; as epistemic communities 5 ; policies of 5 , $6-7$; significance of, at national level 186

interpretation of research 19-21

interview guide $25,198-204$

knowledge production and expertise 91

legitimation, defined 4

liquid modernity 93

marketisation of education: in China $52-53,54,61$; in Russia 59, 62 material benefits of QAE policies 140-141, 152-156

meritocracy in China 101-102

Ministry of Education: Brazil 47, 48, 99-100; China 28-29, 52, 53, 55, 83, 105; Russia 29-30, 35, 59, 86

model, defined 8

National Agency for Control and Supervision in Education (Rosobrnadzor, Russia) 29-30, 106, 108, 120, 121

National Assessment of Education Quality (NAEQ, China): data availability and 123-125; data circulation and 119; data production and 122; data use and 128-130; overview 102-103, 116, 143-144; perceptions of 171

National Education Plan 2014-2024 (PNE, Brazil) 166, 167

national education systems and governance 95-97
National Institute for Educational Studies and Research (INEP, Brazil) 99-101, 118-119, 123, 126

national large-scale assessment (NLSA) 121; see also circulation of data; Evaluation System of Basic Education; National Assessment of Education Quality; Unified State Exam national QAE policy communities 72-79 networked governance 98 new public management 139, 157

organisational analysis 140

Organisation for Economic Co-operation and Development (OECD): policies of 5,6 ; recommendations of 183 ; role of 7; Teaching and Learning International Survey 77-78, 125; see also PISA survey

Outline of National Plan for Medium and Long-term Education Reform and Development (China) 170

path dependencies 4, 45, 162

PIRLS (Progress in International Reading Literacy) 58

PISA survey (Programme for International Student Assessment) 7, 74, 141

policymaking: expertise and 91; ontological assumptions about 3-4; QAE as tool of 2; ruptures of status quo and 71-72; see also expertise/experts

policy monopolies 71-72

policy process theories $21-22$

policyscape 24

policy transfer: comparative education and $4-5$; problems with idea of 181 ; in Russia 87

political possibilities in CADEP framework: dynamics of 182; overview 21, 22-23, 121

political situation in CADEP framework: dynamics of 182; overview $21,21-22$

political space see use of political space in CADEP framework

politicking 182, 182, 186

politics, defined 3

politics of quality, as enabling or hindering action 188-189

power: of measurements 117-118; QAE as tool of 2; of top-performing schools 155

problematisation 23

Programme for International Student Assessment (PISA survey) 7,74, 141 progress, constant, belief in 163 
Progress in International Reading Literacy (PIRLS) 58

punishments for poor performance 147-150

Qualitative Content Analysis 31-32, 196 quality assurance and evaluation (QAE):

defined 1; as framing factor in education 180-181, 182-184, 188-189; interest in 44,61 ; in local governance $138-140$; local governance of schools through 145-151,157-158; as political 18; resources gained through 140-141; schools' room for action in 152-156; as tool to exercise power 2; transnational agenda of 5-7; see also dynamics in politics of quality; future of QAE; historical paths towards quality assurance and evaluation

reactive sequences 45

reflective research 18-19, 32-39

reputation of schools $154-155,158$

resource distribution to schools based on performance 153-154, 156, 158

rewards for good performance 148-150

role-setting, destabilising and reorganised 186-188, 189

room for action: in case countries 88 ; of expert communities 185 ; of research 39-41; of schools 137-138, 152-158

Rosobrnadzor (National Agency for Control and Supervision in Education, Russia) 29-30, 106, 108, 120, 121

Russia: archetypal images of future in 175-176; building capacity in 78-79; Cheboksary 141-142; data circulation in 119-120; data collection in 29-31; engagement with international community 74 ; historical trajectories and pushes of present in 171-173; path towards QAE in 56-60, 62; perceptions of future in 173-174; political situation in 34-36; rise of school performance evaluation in 144-145; school visits in 36-38; state and expertise in 105-109; state-dependent QAE in 84-87; see also Unified State Exam

SAEB see Evaluation System of Basic Education scholars and policy in China 83-84 schools: as actors 140-141; local governance of, through QAE 145-151; policy and 137-138; room for action in QAE of $152-158$

social construction of space 24

Stalinist school model 56

standardisation, defined 4

state: changing role of 93-97; data collection and 92; as education actor 7; expertise and, in Brazil 99-101; expertise and, in China 101-105; expertise and, in Russia 105-109; relationship between expertise and 92-93, 109-111

State Final Attestation (SFA, Russia) 144-145, 173-174

State Programme for Education Development, 2013-2020 (Russia) 173

steering tools of governance 94-95 supervision system in China 51-52, 53, 143 symbolic benefits of QAE policies 140-141, 152-156

systematics of research procedure: data collection 27-31; overview 25-26; qualitative content analysis 31-32; themes of goals of data collection and analysis $\mathbf{2 6}$

theory, defined 8

TIMSS (Trends in International Mathematics and Science) 37, 58

transitional stages in Brazil 164-165 transnational, defined 2, 20

transnational agenda of quality assurance and evaluation 5-7

“Transnational Dynamics of Quality Assurance and Evaluation Policies in Brazil, China, and Russia" 2

transnational expert community $87-88$ transnational nature of work of experts 98

Unified State Exam (USE, Russia): data availability and 125-126; data circulation and 119-120; data production and 121-122; data use and 130-131; foreign expertise and 86-87; overview 59-60, 116, 144-145; perceptions of 173-174

United Nations Educational, Scientific and Cultural Organisation (UNESCO) 5, 6 use of political space in CADEP framework 21, 23-25

World Bank 5, 6-7, 183

world culture theory 4 